3. From: (Originating Organization)

Distribution

5. Proj./Prog./Dept./Div.:

RFSH Waste Management/CWC

8. Originator Remarks:

Release of Final Report for the Operational Readiness Review for Project $W-112 / I S B$ at the Central Waste Complex.

11. Receiver Remarks:

11A. Design Baseline Document?

$\square$ Yes $\square_{\text {No }}$
1. EDT Page 1 of $\frac{1}{703050}$

4. Related EDT No.:

619283

7. Purchase Order No.:

$\mathrm{N} / \mathrm{A}$

9. Equîp./Component No.:

$N / A$

10. System/BIdg./Facility:

Central Waste Complex 12. Major Assm. Dwg. No.:

N/A

13. Permit/Permit Application No.:

$N / A$

14. Required Response Date:

06/01/97

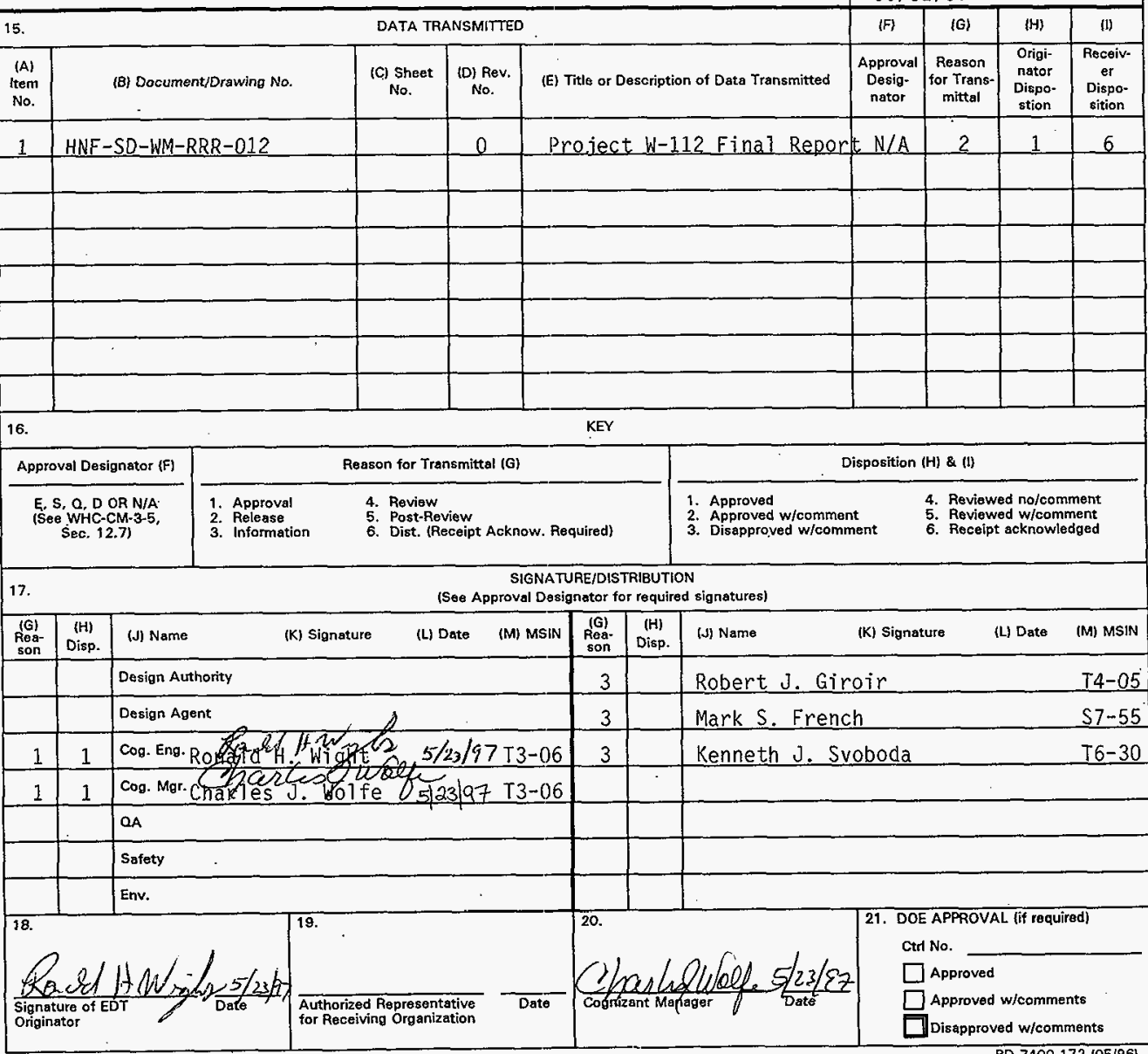




\title{
Phase V Storage (Project W-112) Central Waste Complex Operational Readiness Review, Final Report
}

\author{
Ronald H. Wight
}

Rust Federal Services Hanford, Richland, WA 99352

U.S. Department of Energy Contract DE-AC06-96RL13200
EDT/ECN: 703050
UC: UC-900
Org Code: 87700
Charge Code: A41D2
B\&R Code: EW3130020
Total Pages: 356

Key Words: CWC, Contractor ORR, Project W-112

Abstract: This document is the final report for the RFSH conducted, Contractor Operational Readiness Review (ORR) for the Central Waste Complex (CWC) Project W-112 and Interim Safety Basis implementation. As appendices, all findings, observations, Tines of inquiry and the implementation plan are included.

TRADEMARK DISCLAIMER. Reference herein to any specific commercial product, process, or service by trade name, trademark, manufacturer, or otherwise, does not necessarily constitute or imply its endorsement, recommendation, or favoring by the United States Government or any agency thereof or its contractors or subcontractors.

Printed in the United States of America. To obtain copies of this document, contact: Document Control Services, P.0. Box 950, Mailstop H6-08, Richland WA 99352, Phone (509) 372-2420; Fax (509) 376-4989.
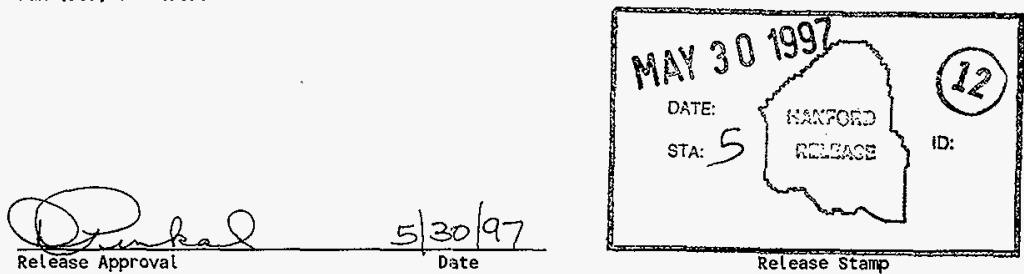


\title{
PHASE V STORAGE (PROJECT W-112)
}

\author{
CENTRAL WASTE COMPLEX
}

\section{OPERATIONAL READINESS REVIEW, FINAL REPORT}

\author{
MAY 22, 1997
}

PREPARED BY

RUST FEDEFIAL SERVICES

OPERATIONAL READINESS REVIEW 


\section{TABLE OF CONTENTS}

* SIgNATURE PAGE

* EXECUTIVE SUMMARY

* INTRODUCTION

* ORR EVALUATION

* LESSONS LEARNED

*
APPENDICES

APPENDIX A

APPENDIX B

APPENDIX $C$

APPENDIX D

APPENDIX E
SECTION I

SECTION II

SECTION III

SECTION IV

SECTION V

SECTION VI
FINDINGS

OBSERVATIONS

LINES OF INQUIRY

REVIEW TEAM PROFILES

ORR IMPLEMENTATION PLAN 


\section{SECTION I}

\section{SIGNATURE PAGE}


CWT PHASE V STORAGE

OPERATIONAL READINESS REVIEW FINAL REPORT REVIEW TEAM APPROVAL SIGNATURES

PERFORMED:

ISSUED BY:

APPROVED BY:

REVIEW TEAM LEADER:

REVIEW TEAM MEMBERS:
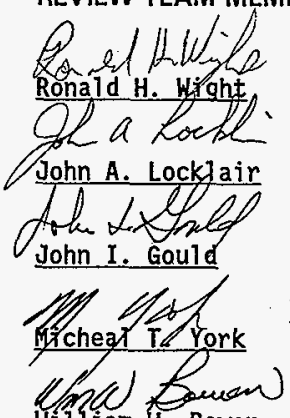

william howe

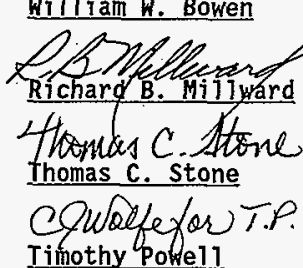

May 9, 1997 TO May 15, 1997

RUST FEDERAL SERVICES OF HANFORD INC.

Charkequoffe charles J. Wolfe

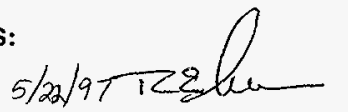

$5 / 22 / 97$

DATE Richard E. Allen

DATE

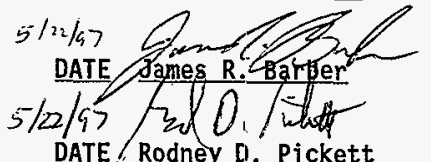

$5-22-97$

DATE

$5 / 23 / 47$

DATE

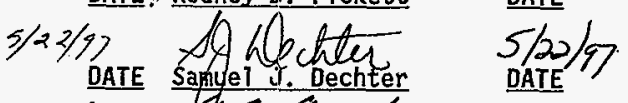

$5 / 22 / 57$

DATE

$5 / 22197$

DATE

DATE Kenneth| M. Mclain

$5 / 22 / 97$

DATE

DATE

shelbold. Turner

$\frac{5 / 23 / 97}{\text { DATE }}$

WC PROJECT H-112/ISB ORR REPORT HNF-SD-WM-RRR-012

REV. 0

MAY 22, 1997 Page 4 


\section{SECTION II}

\section{EXECUTIVE SUMMARY}




\section{EXECUTIVE SUMMARY}

The Central Waste Complex Phase V Storage Operational Readiness Review (ORR) was performed per WHC-CM-5-34, Solid Waste Disposal Operations Administration, Section 1.4, Operationa7 Readiness Activities, and WHC-IP-1048, Operationa7 Readiness Review Activities, Section 1, Performance of Operational Readiness Reviews. A Plan of Action (POA), which specifies the requirements for startup, was developed by the facility and approved by DOE-RL. From the approved POA, the ORR Implementation Plan (ORRIP) was developed and approved by the review team. The ORRIP was used to define and control the process by which the Review Team (RT) conducted its review. The focus of the ORR was the three new storage buildings added to the CWC and the change in the safety basis that resulted from the addition of the new buildings. The RT was comprised of personnel wholly independent of the project.

The ORR consisted of documentation review, observing $p 1$ ant operations and dri11s, personnel interviews, and hand-over-hand inspections. Each RT member reviewed core requirements in which they had experience. The RT determined, through the finding classification criteria, the following findings as significant enough to warrant correction prior to authorization to commence operations:

Emergency Preparedness

Conduct of Drills

Complete implementation of the Interim Safety Basis

Other findings of lessor significance were deemed to be of such a nature as to allow correction after startup (postart). It has been concluded by the RT that the facility is ready to commence operations at the completion of the above mentioned prestart items which are described in greater detail in appendix $A$ of this report. 


\section{SECTION III}

\section{INTRODUCTION}




\section{PURPOSE}

The purpose of this review was to ensure facilities, equipment, personnel, procedures, and management control systems are in place to operate Phase $V$ Storage safely, efficiently, and in compliance with all applicable requirements. For the startup of a modified Hazard Class 2 Nuclear Facility (CWC), with a change to the safety basis, WHC-CM-5-34, Solid Waste Disposal Operations Administration, Section 1.4, Operational Readiness Activities required the performance of an ORR with Operations Office Manager as Approval Authority. The review type and Approval Authority are commensurate with the facility's potential impact on safety and its planned operations.

\section{SCOPE}

The ORR scope included all facilities, equipment, personnel, procedures, and management control systems needed to support or interface with Phase $V$ Storage operations and maintenance. Interfacing operations, activities, and organizations were reviewed to the extent in which they affected Phase $V$ Storage or Phase $V$ Storage affected them. The ORR reviewed specific requirements to the breadth defined in HNF-SD-WM-PLN-124, P7an of Action for Phase V Storage Operational Readiness Review and to the depth defined in HNFSD-WM-IP-011, Implementation Plan for Phase $V$ Storage Operational Readiness Review. The review process and methodologies consisted of the following basic steps :

$\checkmark$ Core requirements assigned to Review Team members

$\checkmark \quad$ Facility assessed by use of the criteria and review approaches presented in the IP (assessments consisted of documentation review, observing operations and drills, hand-over-hand inspections, and personnel interviews).

$\checkmark$ Findings, observations, and assessment performance documented.

$\checkmark \quad$ Multiple similar findings combined.

$\checkmark$ Findings were classified as either prestart or poststart.

$\checkmark \quad$ Findings and observations tracked to closure.

\section{REVIFW TEAM}

The review team was composed entirely of personnel independent of the project from the following disciplines: Engineering; Nuclear Safety; Industrial Safety; Quality Assurance; Conduct of Operations; Management; Maintenance; Emergency Preparedness; Health Physics; Environmental Compliance.

\section{FACILITY DESCRIPTION}

The Phase $V$ Storage (Project $W-112$ ) was constructed to provide additional mixed solid waste storage space in the Central Waste Complex (CWC) to store containers prior to processing and/or treatment. The CWC is operated by RUST 
Federal Services of Hanford Inc. (RFSH) Solid Waste Management Organization. The W-112 project included infrastructure work, a maintenance traiTer Supporting the Waste Receiving and Processing Plant (WRAP), and a support trailer supporting WRAP, as well as the three Phase $V$ Storage buildings. The WRAP trailers have been previously accepted, are in operation, and will not be included in the scope of the ORR for the Phase $V$ Storage buildings.

therefore, subsequent reference to Project $W-112$ will only be in relation to the three additional storage buildings 2404 series, to be incorporated into the CWC.

The Phase $V$ Storage buildings are located in the CWC 200 West area and are bounded by Dayton Avenue, 23 rd street, and 16 th street. Phase $V$ Storage consists of three long-term drum storage buildings that will provide 13,300 drum equivalent of radioactive and mixed solid waste storage space.

Construction is similar to existing CWC structures. Contact-Handled (CH) wastes from onsite and offsite generators are to be stored. Waste will include low-level, mixed low-leve1, transuranic (TRU), suspect TRU, TRU-mixed, and remote-handled waste shielded down to $\mathrm{CH}$ packages. The storage area will be capable of receiving and accommodating 208-1iter (55-gallon) and/or 322liter (85-gallon) pelletized drums stacked up to three high, and other waste packages such as steel boxes.

The design utilized manual waste storage and waste package transport concepts (e.g., pelletized containers and forkl ift transport) to safely and compliantly store solid waste. The storage area will be accessible to appropriate drum and/or pallet moving equipment. The facility is equipped with a fire suppression system, 120 volt and 480 volt electrical system, telephone, sanitary/raw water system, freeze protection, new and/or upgraded access roads, sidewalks, fencing, fire al arm system, radio fire alarm reporter, exhaust ventilation, nonisokinetic record samplers, ventilation, fire detection interlocks, portable fire extinguishers, slopped epoxy coated floors, 1iquid collection curbing and/or catch basins, personnel doors, rol1up doors, lighting, and emergency lighting.

Incoming solid waste will be routed to the storage buildings for log-in. Drums will be categorized and routed to appropriate areas. When required, stored waste will be transferred from various storage locations to other storage areas, other Waste Management Operations facilities, to onsite disposal facilities (e.g., low-level burial ground, mixed low-1evel waste disposa1, etc.) and to offsite commercial treatment facilities. 


\section{SECTION IV}

\section{ORR EVALUATION}




\section{ORR EVALUATION}

This section of the report summarizes the ORR team activities and conclusions for each of the core requirements. Details related to each individual

criterion and approach are in section VI, Appendix C, Lines of Inquiry. Those items considered to be findings are more fully identified in Section VI, Appendix A. Those items classified as observations are included in their entirety in section VI, Appendix B.

Core Requirement 1: "There are adequate and correct procedures and safety limits for operating the process systems and utility systems."

Facility operating and alarm response procedures were reviewed for incorporation of Interim Operational Safety Requirements. Procedure technical content is considered satisfactory for startup.

Operations personnel were interviewed and observed in the field during walkdowns to ensure an understanding of procedure use. Minor deficiencies were noted in this area as outlined in observations/Finding. However, operations personnel knowledge and procedure use is considered satisfactory for startup.

Core Requirement 2: "training and qualification programs for operations and operations support personnel have been established, documented, and implemented (the training and qualification program encompasses the range of duties and activities required to be performed."

Verification for this Core Requirement included reviewing training procedures, records, and lesson plans, reviewing training program content, interviewing training personnel, and reviewing progress toward achieving a needs and task based training curriculum complying with DOE Order 5480.20A.

Training records are complete, are maintained neat and orderly, and are easily retrievable. The training program requirements and policies are described in WHC-CM-5-34, Section 1.8. This procedure is complete and detailed. Although the final products, the training lesson plans and On the Job Training Performance meet the requirements, the historical development of the requirements analysis is lost in the mists of time. Work is underway to develop and document a new training curriculum which will meet the DOE Order $5480.20 \mathrm{~A}$ requirements. This task is due to complete by the end of FY1997. Personnel interviews revealed that training instructors and training $p$ ian preparers are qualified and trained to perform their tasks. A lesson on the new. ISB and the new storage buildings was presented to the ORR team and demonstrated satisfactory classroom performance. As noted in core Requirement $\# 3$, the level of knowledge of personnel still needs to be improved prior to start up. Although the ISB training provided to the Solid Waste personnel did not include a knowledge examination, this Core Requirement is considered satisfactory for startup after completion of prestart finding 3.1.1 
Core Requirement 3: "Level of knowledge of operations and operations support personnel is adequate based on reviews of examinations and examination results, and selected interviews of operating and operations support personnet."

No examinations were given for implementation of the Interim Operational Safety Requirements (IOSRs) derived from the Interim Safety Basis. Interviews were used to determine the level of knowledge of operations and operations support personnel. Level of knowledge of operations personnel is considered satisfactory for startup.

Interview results indicate level of knowledge deficiencies for the IOSR of operations support personnel in two areas. Specifically, operations support personnel interviewed were weak in their knowledge of the "Restricted". mode of facility operation and the specific administrative controls established by the IOSRs. (See Finding F.3.1.1). Level of knowledge of operations support personnel requires upgrade prior to startup.

Core Requirement 4: "Facility safety documentation is in place that describes the 'safety envelope' of the facility. The safety documentation should characterize the hazards/risks associated with the facility and should identify mitigating measures (systems, procedures, administrative controls, etc.) that protect workers and the public from those hazards/risks. Safety systems and systems essential to worker and public safety are defined and a system to maintain control over the design and modification of facilities and safety-related utility systems is established."

The authorization basis document is in place and approved by both the subcontractor and the Department of Energy. Safety systems and controls applicable to protecting the worker, environment, and public are in place and actively applied throughout the facility from the Management tier down to the worker.

Interviews with plant personnel documented on the LOI form revealed a high degree of knowledge and responsibility relating to worker safety and the mechanisms and programs that functionally achieve that end product. All personnel interviewed, from the Manager down to the Nuclear Process 0perator consistently replied with the same answers. This reveals a consistent attitude, training, and attention to safety throughout the organization.

The is an effective change control mechanism that follows the DOE directive for Nuclear facilities in managing change.

Core Requirement 5: "A program is in place to confirm and periodically reconfirm the condition and operability of safety systems, including safety related process systems and safety related utility systems. This includes examinations of records of tests and calibration of safety system and other 
instruments which monitor Timiting conditions of operation or that satisfy Technical Safety Requirements. All systems are currently operable and in a satisfactory condition."

This requirement confirms the condition and operability of the safety systems. The buildings in question in the $W-112$ project are turn-key operations meaning the facility was constructed and tested (ATP) by the vender. However, overview was maintained by KEH and WHC. The ATP and Operation and Maintenance documentation prepared by the vendor appears thorough. Documentation was verified by both KEH and WHC. A formal OTP was not performed but was built into the initial PM for the systems. This Core Requirement is satisfactory for startup.

Core Requirement 6: "A process has been established to identify, evaluate, and resolve deficiencies and recommendations made by oversight groups, official review teams, audit organizations, and the operating contractor."

This core requirement covered evaluation of the process to identify, evaluate, and resolve deficiencies and recommendations made by oversight groups, official review teams, audit organizations, and the operating contractor by a review of the Corrective Action P1an developed and implementation status resulting from the FEB assessment of December 1996, at CWC and T-P1ant. The review found the Plan to be fully developed and all corrective actions being tracked to completion. Each corrective action has been entered in HATS. A formal root cause analysis has been made of the four core findings of the FEB. There were no open corrective actions that would preclude start-up of the Phase V Storage Buildings. The system for communications during emergency conditions was a FEB finding that is further evaluated elsewhere in this report as a post start activity.

Core Requirement 7: "A systematic review of the facility's conformance to applicable DOE orders has been performed, any nonconformances have been identified, and schedules for gaining compliance have been justified in writing and formally approved."

Verification of this requirement consisted of reviewing the facility's conformance to applicable DOE Orders. The facility is operating to an approved S/RID, WHC-IP-1120 rev. 4. A Phase 1 and Phase 2 assessment were completed. A recent review by DOE-RL questioned the phase 1 assessment and required a correction action $\mathrm{plan}$. A review by RFSH formulated a plan to replace the existing S/RID and perform a new phase 1 to demonstrated compliance with applicable DOE Orders. Plan and schedule were approved by DOE. This Core Requirement is satisfactory for startup.

Core Requirement 8: "Management programs are established, sufficient numbers of qualified personnel are provided, and adequate facilities and equipment are available to ensure operational support services (e.g., training, maintenance, 
waste management, environmental protection, industrial safety and hygiene, radiological protection and health physics, emergency preparedness, fire protection, quality assurance, criticality safety, and engineering) are adequate for operations."

Note: This core requirement requires review of support services management programs, personnel, facjlities, and equipment which were established and procured specifically for the facility. Due to the many areas to be reviewed, this core requirement was divided into 12 separate items and are presented as follows:

8.1: "There is an adequate emergency preparedness organization and program."

See summary for Core Requirement 9.

8.2: "There is an adequate engineering support organization and program including the cognizant/system engineer approach.

Verification of this requirement looked into the adequacy of engineering support including cognizant/system engineer approach. The guidance documents as implemented utilize sufficient structure to ensure thorough cover of engineering principles in all areas of CWC including the new facilities in project $W-112$. Discussion outside of Engineering assure that sufficient engineering support was being provided in a timely fashion to support safe operation and maintenance within the CWC. This Core Requirement is satisfactory for startup.

8.3: "There is an adequate environmental protection organization and program, to include air quality, surface water, groundwater, solid and hazardous waste, hazardous material handling, environmental monitoring, hazardous substance release reporting, and environmental protection quality assurance."

The review approach for CR 8.3 was to verify that an environmental protection program is in place, and being effectively implemented. A previous assessment by the Facility Evaluation Board reviewed the SWD environmental program to an even greater degree of detail during the period Dec 9-20, 1996. This ORR concentrated on looking for issues within the CWC Environmental Compliance organization, and the proposed changes due to bringing Phase $V$ buildings to a "ready-to-receive-waste" state, which would demonstrate that a process of continuing improvement was being followed in implementing the existing environmental program.

A comprehensive screening of the Standards/Requirements Identification Document (S/RID, WHC-IP-1120) was made to determine compliance vs. best management practices in the existing Phase $V / C W C$ environmental program. This screening resulted in many more approach items than were able to be verified during the limited schedule of the Phase V ORR. 
Most of the S/RID items relating to operation of the Phase $V$ buildings under the new ISB document were already covered as part of the continuing environmental program. A random number of items from the S/RIDs screening was pursued in greater detail, inciuding participation in the emergency drill critique process.

From this detailed approach, one (1) finding (submitted as a Pre-start item) and several observations were developed. Of the observations, two relate to good practices and demonstrate the pro-active style of the CWC EC organization.

The overall impression is that the CWC environmental protection program is being adequately implemented, and meeting its basic requirements. The finding and observations are submitted with the intent of providing goals and suggestions for continued improvement, associated with operation of the Phase $\checkmark$ buildings.

\section{4: "There is an adequate fire protection program."}

All criteria of Core Requirement were reviewed for completeness by the facility, and found to be in generally good condition. Drawings were walked down and individuals were interviewed to determine readiness of the facility. The overall result was two findings; one having to do with the installation of the sprinkler system itself and the other was a tagging issue on the fire system valves. These findings are recorded under Core Requirement 15. After the facility has successfully dealt with these specific deficiencies, the elements of this Core Requirement will be considered satisfied to safely start up and operate the facility.

8.5: "There is an adequate maintenance organization, program and work control system."

\section{CONCLUSION:}

While there remain some problems within the department, none were evident that would be of sufficient concern to affect the operational readiness to start this facility.

Maintenance requirements of the $W-112$ project are fulfilled by the existing Solid Waste Management Division maintenance organization. All facets of the maintenance program described in DOE $4330.4 \mathrm{~B}$ are addressed in an approved Maintenance Implementation Plan (MIP) (WHC-SP-0851, May 5, 1995) which already encompasses the Central Waste Complex of which Project $W-112$ is a part. Maintenance of the building fire systems is the responsibility of the Fire Systems Maintenance organization of the Hanford Fire Department (HFD). There are no Technical Specification Requirements associated with any of the W-112 maintenance activities. 
Because maintenance is addressed by an existing approved MIP and has recently been assessed by the Facility Evaluation Board (FEB) (December 1996) this Operational Readiness Review has been limited to determining the attitudes of the maintenance work force and their readiness to support operations of the new buildings, and overall progress towards meeting the findings of the FEB. To determine this information interviews were held with maintenance personnel (Paul Hemsworth, Dennis Rettkowski, Beth Wright, and several craftpersons) and supporting documentation was reviewed (the MIP, the FEB report, pertinent sections of CM-5-34 and CM-5-36, maintenance technical procedures).

1. Worker Attitude

Interviews indicated that the maintenance personnel, for the most part, have a good attitude toward their work. Workers felt they possessed the skills and had the support of management for tools, equipment, and training, when needed.

This reviewer was gratified to discover that most if not all maintenance personnel had received training and understood the relationship of their work to supporting the Authorization Basis (although one craftsman interviewed did not immediately recognize the term "ISB," did recognize "FSAR" and immediately made the connection). The organization is to be commended for this practice.

2. Progress against $F E B$ findings

The FEB found four deficiencies:

- Lack of specific goals and performance metrics

- Failure to analyze and implement corrective actions for schedule or work-package non-performance

- Lack of resource-loaded schedules

- Failure to perform activities or commitments identified in the MIP

To address these findings, and to implement other improvements, Rust Federal Services of Hanford, Inc. (RFSH) has embarked on a major reorganization of their maintenance program. All RSFH maintenance planning/scheduling activities are to be centralized, as are most craft assets. Some craft assets will remain assigned to specific facilities within the RFSH organization, with the remainder being used to address major maintenance activities at whatever RFSH facility scheduled. While this reorganization is already under way, none of the immediate changes affect the performance of maintenance for Project $W-112$.

Participants in the reorganizational planning have indicated to this reviewer that, although some progress has already been made, all of the FEB findings will be fully addressed under the new organization.

To address the new organizational program, RFSH needs ensure a MIP is quickly written and approved, and the existing MIPs canceled. 
8.6: "There is an adequate quality assurance organization and program."

This core requirement covered evaluation of the adequacy of the quality assurance organization and program at the Central Waste Complex. Quality Assurance Program documentation, including WHC-CM-5-34) was reviewed for adequacy and was found to be adequate for continued operations and start-up of the Phase V Storage Buildings. Quality Assurance review and approval requirements are determined by the cognizant engineers who have review/approval designation authority for all support functions. Most of the work is routine and QA approval is seen more frequently on procedure development and upgrades. The SWITS software was forma7ly verified and validated in accordance with the requirements of IEEE 830-1984. Changes are formally controlled and in accordance with the requirements of WHC-CM-4-2 Quality Assurance Program. A review of the SWITS V\&V CHRONOLOGICAL LOG indicates that the essential requirements of WHC-CM-5-36 were satisfied. There were no pre or post start findings for this core requirement.

8.7: "Health physics (HP) programs and procedures provide appropriate direction, effectively support safe operation of the facility, and ensure adequate protection of workers, the public, and the environment."

The verification process for this core requirement involved program reviews and interviews with Solid Waste Management (SWM) personnel. The SWM Radiological Control (RadCon) program meets the requirements of 10 CFR 835 , FDH Radiation Protection Program, and the Hanford Site Radiological Control Manual. Interviews with SWM employees and managers led to the conclusion that individuals understood radiological control is an integral part of their daily duties and that ALARA is everyone's responsibility. This Core Requirement is satisfactory for startup.

8.8: "Industrial hygiene and safety programs, policies, and procedures have been developed which are consistent with the hazards present or anticipated in the working environment as well as with DOE orders and OSHA standards. The overall program is effectively managed to promptly address and remedy hazards, and systems are in place tao communicate information to workers in order to prevent occupational injuries and i11nesses."

Industrial Hygiene and Industrial Safety were reviewed in depth to satisfy this Core Requirement. Several walk downs of the 2404 series buildings were conducted with the operators and the safety representatives. The facility's HASP was also reviewed. The result of the review was a single finding having to do with the pre-occupancy hazard analysis documentation. After the resolution of this item the facility will have satisfied this core requirement 
to safely start up and operate the new W2404 series buildings in accordance with requirements, including the ISB.

8.9: "There is a security organization and program that adequately supports the requirements of the Phase $V$ Storage area.

Per the DOE approved POA developed by the facility, this core requirement was not to be reviewed during the course of this review.

8.10: "There exists and adequate configuration management program to assure necessary change and drawing control of plant structures, systems, and components and to assure changes are reflected in training, procedure development, maintenance instructions, and technica] baseline."

HNF-CM-5-34, Section 2.4, Configuration Management; HNF-CM-5-34, Section 2.1, Configuration Change Control; and HNF-CM-5-34, Section 1.24, Unreviewed Safety Questions; adequately define an administrative program to ensure that future proposed changes remain compliant with the safety basis and that modifications are analyzed, documented, approved by appropriate personnel, and reflected properly in new/revised procedures, drawings, and training materiais. The understanding of configuration control, as tested by interviewing seven (7) members of the Central Waste Complex organization, is adequate to ensure proper implementation of configuration control requirements. The evidence examined and documented by this review indicates that Core Requirement 8.10 has been met and Phase $V$ Storage is ready to operate from a configuration management process perspective.

8.11: "An adequate records management/document control program exists to assure that all important documents, records, and related information are maintained current and readily available."

This core requirement only evaluated Records Management as it pertained to startup and operation of the 2404 facilities. All organizations manage their documents adequately and provide the necessary controls for operation. Their were no findings for this core requirement. The facility will be able to safely start up operations in this area.

\subsection{2: "There exists an occurrence reporting/root cause program."}

This core requirement dealt with verifying that an occurrence reporting/root cause program exists with knowledgeable and independent (if applicable) personnel conducting investigations. The root/cause analys is for the four core FEB findings were reviewed and were found to be complete and pertinent to the issues raised. In addition the occurrence reports for Solid Waste Disposal were also reviewed. These showed there is a program in place. Interviews with both operations and support staff led to the conclusion that investigations are conducted by personnel independent from the event being investigated to the extent possible and that there is no hesitation at al in 
seeking expertise from outside the organization when a benefit can be achieved by doing so. There were no pre or post start findings for this core requirement.

Core Requirement 9: "A routine and emergency operations drill program, including program records, has been established and implemented."

A COMBINATION OF WALK AROUNDS AND DOCUMENTATION VERIFICATIONS WERE PERFORMED DURING THE REVIEW. OVERALL THE EMERGENCY PREPAREDNESS PROGRAM IS IN PLACE AND PERSONNEL CAN RESPOND TO EMERGENCY EVENTS. HOWEVER PERSONNEL NEED MORE TRAINING TO MEET THE RIGID REQUIREMENTS EXPECTED OF THE EMERGENCY ORGANIZATION BY THE FACILITY MANAGER AND SITE EMERGENCY PREPAREDNESS.

PERSONNEL WERE TRAINED AND DOCUMENTATION WAS IN PLACE FOR VERIFICATION AND THE BUILDING EMERGENCY PLAN WAS CURRENT AND IN PLACE. ADDITIONAL TRAINING AND DRILL PARTICIPATION WILL BE NEEDED IN THE FUTURE TO ENHANCE THEIR RESPONSE AND CONTROL OF EVENTS THAT COULD OCCUR.

IT SHOULD BE NOTED THAT SOLID WASTE MANAGEMENT HAS IMPROVED IN THE AREA OF EMERGENCY PREPAREDNESS IN THE LAST SIX MONTHS. IMPROVEMENTS TO THE BUILDING EMERGENCY PLAN, AND AN UPCOMING BUILDING EMERGENCY GUIDE ARE EXAMPLES OF IMPROVEMENT. OTHER EXAMPLES ARE PARTICIPATING IN A DRILL DURING THE ACCOUNTABILITY AIDE CLASS AND SIGNS DIRECTING PERSONNEL TO THE DESIGNATED STAGING AREA POSTED IN THE OUTLYING AREAS.

UPON SATISFACTORILY COMPLETING AN ADDITIONAL DRILL IN WHICH ORR MEMBERS OBSERVED AND DETERMINED THAT IMPROVEMENTS BY PERSONNEL PARTICIPATING IN THE DRILL AND PERSONNEL CONDUCTING THE DRILL HAVE SHOWN COMMAND AND CONTROL, GOOD RADIOLOGICAL CONTROL PRACTICES AND ADEQUATE DRILLMANSHIP, CORE REQUIREMENTS 8.1 AND 9.0 ARE CONSIDERED SATISFACTORY FOR STARTUP.

Core Requirement 10: "An adequate startup or restart test program has been developed that includes adequate plans for graded operations testing to simultaneously confirm operability of equipment, the viability of procedures, and the training of operators."

Per the DOE approved POA prepared by the facility, this Core Requirement was not to be reviewed during this ORR.

Core Requirement 11: "Functions, assignments, responsibilities, and reporting relationships are clearly defined, understood, and effectively implemented with line management responsible for control of safety."

The Solid Waste Management Operations organization chart clearly identifies the structure and reporting relationships within the organization. Operations and the support groups report to a single individual, the Manager, Solid Waste. The training record file for each person contains a position description describing that position ${ }^{*}$ s duties and responsibjlities. Personne] interviews were conducted with various members of the organization. These interviews led to the conclusion that personnel understand their responsibilities, their impact on and responsibility for safety, information 
flow within the organization, and personnel interactions within the organization. This Core Requirement is satisfactory for startup.

Core Requirement 12: "The implementation status for D0E Order 5480.19, Conduct of Operations requirements for DOE facilities, is adequate for operations."

Verification for this Core Requirement included documentation and field observation reviews in the areas of Shift Routines and Operating Practices, Communication, Control of Equipment and System Status, Lockout and Tagout, Al arm Management, Logkeeping, Operations Turnover, Required Reading, Timely Orders to Operators, Operations Procedures, Operator Aid Posting, and Equipment and Piping Labeling.

The basic program elements are in place for all conduct of operations areas reviewed and are considered satisfactory for startup.

The controlling organization's lock and tag procedure does not designate how and where an authorized worker's lockout/tagout will be applied. (See Finding 12.1.1). This deficiency requires correction prior to startup.

Core Requirement 13: "There are sufficient numbers of qualified personnel to support safe operations."

This core requirement was to verify there are sufficient numbers of qualified personnel to support safe operations and that the authorization basis minimum requirements are satisfied. The ISB requires only one qualified operator, one supervisor, and one rad. con. tech. for safe operations. Interviews with management indicated that there could be as few as one and, as many as six teams in the field at any given time depending on the volume of waste received. The eleven operators are each certified in three out of six possible areas and are backed up by operators from the burial grounds (12 ea.) who are cross trained and certified for CWC operations. There are ten rad. con. techs. that can be made available on an as needed, case by case, basis with full time coverage provided for high radiation exposure tasks. Operations is staffed by one manager, three leads, and three additional support staff members. The support organizations are also adequately staffed. There were no pre or post start findings for this core requirement.

Core Requirement 15: "The facility systems and procedures as affected by facility modifications, are consistent with the description of the facility, procedures, and accident analysis included in the safety basis.

This core requirement evaluated whether the W112 project 2404 facility has been correctly included into the CWC operating boundaries and that the associated Interim Safety Basis is being complied with. A thorough review of a11 project documentation was conducted including how that information was 
utilized by the operating organization to assure long term operability. The Solid Waste Organization has done a commendable job in preparing the 2404 facilities for operation and preparing their staff for proper implementation of the ISB. The organization and facilities are ready for operation upon closeout of the pre-start findings.

Core Requirement 19: "The technical and management qualifications of contractor personnel, responsible for facility operations, are adequate."

Verification for this Core Requirement consisted of reviewing position descriptions containing the duties and responsibilities for managers and Lead personnel and of interviewing several persons. The interviews led to the conclusion that Lead personnel and managers are technically qualified by education, training, and experience to perform their duties and that they understand their responsibility for safety and for environmental protection. This Core Requirement is satisfactory for startup.

The approved $\mathrm{P} 7$ an of Action eliminated the need for a contractor review of core requirements $14,16,17,18,20$. 


\section{SECTION V}

\section{LESSONS LEARNED}




\section{LESSONS LEARNED}

1) The review team needs to be in place well in advance of the review so they have plenty of time to not only complete required reading and training, but also they have enough time before the review begins to have al. of the Lines of Inquiries completed before the review begins so the review time can be more effectively used for conducting interviews and completing facility walkdowns.

2) The facility needs to publish realistic schedules so the team can better plan their individual schedules to match up with the time allotted for the review.

3) Each team member should not be overloaded with too many core Requirements if the review has a short time allotted. This review was on $7 y$ days and some of the members had 3,4 core requirements and found that the review was difficult to make as complete as was desired.

4) The Plan of Action and Implementation Plan need to be approved well in advance of the review so that the facility and the review team have ample time to $\mathrm{plan}$ the review and what gather documentation, perform self assessments, etc. 


\section{SECTION VI}

\section{APPENDICES}


APPENDIX A

FINDINGS 


\begin{tabular}{|c|c|c|}
\hline \multicolumn{3}{|c|}{ PROJECT W-112/CWC ISB ORR MASTER FINDINGS LIST } \\
\hline No. & DESCRIPTION & PRE/POST \\
\hline 1.1 & $\begin{array}{l}\text { Emergency Procedures do not incorporate a11 } \\
\text { required actions from the Building Emergency Plan } \\
\text { (BEP), HNF-IP-0263-CWC; emergency procedures were } \\
\text { not consulted by BED during drill. }\end{array}$ & PRE \\
\hline 3.1 .1 & $\begin{array}{l}\text { Interviews of personnel who had been provided } \\
\text { training on the Interim Safety Basis indicated } \\
\text { general level of knowledge weaknesses in two } \\
\text { specific areas: } \\
* 5 \text { of } 5 \text { personne] interviewed could not explain } \\
\text { the restricted mode of facility operation. } \\
\text { * } 5 \text { of } 5 \text { personnel interviewed could not explain } \\
\text { the administrative controls established in the } \\
\text { IOSR's. All individuals were able to provide at } \\
\text { least one administrative control. }\end{array}$ & PRE \\
\hline $8-1.1$ & $\begin{array}{l}\text { Emergency Preparedness program is less than } \\
\text { adequate. }\end{array}$ & PRE/POST \\
\hline $8-3.5 .1$ & $\begin{array}{l}\text { Hazards awareness at } C W C \text { and preparations for } \\
\text { Phase } V \text { utilization do not give balanced attention } \\
\text { to non-radioactive and radioactive sources in } \\
\text { accordance with possible waste stream inputs which } \\
\text { will enter } 2404-W A \text {, WB, WC. }\end{array}$ & PRE \\
\hline $8-8.1 .1$ & $\begin{array}{l}\text { A documented preliminary hazards assessment of the } \\
2404 \text { series storage buildings has not been } \\
\text { completed for illumination requirements. }\end{array}$ & PRE \\
\hline 9.1 .1 & Dri11 program is less than adequate. & PRE/POST \\
\hline 12.1 .1 & $\begin{array}{l}\text { DOE-RL-SOD-INST-L\&T.001 Rev } 1 \text {, Section } 4.1 \\
\text { requires, in part, that the controlling } \\
\text { organization's procedure specify how and where an } \\
\text { authorized worker's lockout/tagout is applied. } \\
\text { Section } 2.9 \text { (Lockout and tagout) of RFSH-200 (the } \\
\text { controlling organization's procedure which } \\
\text { replaced WHC-CM-5-34, Section } 3 \text {. 14) does not } \\
\text { specify how and where an authorized worker's } \\
\text { lockout/tagout is applied. Specifically, } \\
\text { instructions are not included for how and where an } \\
\text { authorized worker's lockout/tagout is applied by } \\
\text { itself (without documentation). }\end{array}$ & PRE \\
\hline
\end{tabular}




\begin{tabular}{|c|c|c|c|}
\hline 15.2 .1 & $\begin{array}{l}\text { The Central Waste Complex Ir } \\
\text { Basis (HNF-SD-WM-ISB-007 Rev } \\
\text { IOSR } 6.2 .2 .1 \text { which requires } \\
\text { responsibility, and communid } \\
\text { and defined for the highest } \\
\text { through intermediate levels } \\
\text { safety and operating organiz } \\
\text { correspondence RFSH-9656450 } \\
\text { 19,1996 did not provide suff } \\
\text { determine how this IOSR was } \\
\text { the facility. }\end{array}$ & $\begin{array}{l}\text { terim Safety } \\
\text { 1) Administrative } \\
\text { "1ines of authority, } \\
\text { ation are established } \\
\text { management levels } \\
\text { to, and including, all } \\
\text { ation positions". RUST } \\
\text { dated December } \\
\text { icient information to } \\
\text { being complied with by }\end{array}$ & PRE \\
\hline 15.3 .1 & $\begin{array}{l}\text { The Solid Waste Information } \\
\text { (SWITS) is not being managed } \\
\text { nuclear safety system. }\end{array}$ & $\begin{array}{l}\text { and Tracking System } \\
\text { or implemented as a }\end{array}$ & POST \\
\hline 15.4 .1 & $\begin{array}{l}\text { The Fire Suppression system } \\
\text { installed per manufacturers } \\
\text { installation drawing } \mathrm{H}-2-823 \\
\text { the fire suppression system } \\
\text { activation of the sprinklers } \\
\text { proper labeling required per } \\
\text { maximum pressure ranges for } \\
\text { pressure and fire main water } \\
\text { the CwC surveillance procedy } \\
\text { restrictive) than the range } \\
\text { Department procedure used fo } \\
\text { series building fire suppres }\end{array}$ & $\begin{array}{l}\text { sprinklers are not } \\
\text { data nor meet the } \\
231 \text {; The components of } \\
\text { that are used for } \\
\text { do not have the } \\
5480.19 \text {; Minimum and } \\
\text { supervisory air } \\
\text { pressure specified in } \\
\text { re are broader (less } \\
\text { specified in the Fire } \\
\text { testing the } 2404 \\
\text { sion systems. }\end{array}$ & PRE \\
\hline
\end{tabular}


FINDING NUMBER: F.1.1

CORE REQUIREMENT NUMBER: 1.0 CORE REQUIREMENT STATEMENT: There are adequate and correct procedures and safety limits for operating the process systems and utility systems.

CRITERIA NUMBER: 3 CRITERIA STATEMENT: Are technical detaits correct and consistent between operating procedures, drawings, system descriptions and training.

CRITERIA NUMBER: 8 procedures

DATE: $5 / 14 / 97$

FINDING STATEMENT:

1) Emergency Procedures do not incorporate all required actions from the Building Emergency Plan (BEP), HNF-IP-p263-CWC.

2) The Building Emergency Director did not consult any emergency procedure except for the Emergency Action Levels.

\section{DISCUSSION/CONCLUSION:}

1) Operating procedure SW-001-310 does not include steps all of the actions described in section 7.2.6 of HNF-IP-0p63-CWC. The BEP requires the discoverer to notify the fire departme th which is not a step in 5W-001-310. Several of the BED actions from the BEP are not included in SW-001-310.

2) During the observed drill, the BED fid not utilize any procedures except the EALs which he reviewed for categorizing the event. HNF-IP-0263-CWC section 7.2.6 has specific steps for a Hazardous Material, Radioactive and/or Mixed Waste Spill. This resulted in the BED missing notification of the fire department of a mixed waste spill which was required by the procedure. The Hanford Fire Department must be notified of all hazardous spills. The BED a] so established the ICP at MO-288, buf stationed himself at the scene until late in the dri7l which is contrary to HNF-IP-0263-CWC section 7.2.6. Procedure SW-001-310 was never reviewed for completion of actions and recovery.

\section{RECOMMENDATION:}

1) Revise procedure to match expectatipns.

2) Use procedures and revise them to match how you expect people to respond. RESOLUTION:

SIGNATURES:

TEAM MEMBER:

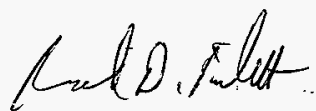

R. D. Pickett

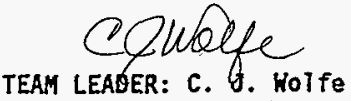


FINDING NUMBER: F.3.1.1

\section{ORR FINDING FORM}

CORE REQUIREMENT NUMBER: 3 CORE REQUIREMENT STATEMENT: Level of knowledge. of operations and operations support p\&rsonnel is adequate based on reviews of examinations, examination results and felected interviews of operating and operations support personnel.

CRITERIA NUMBER: 1 CRITERIA STATEMENT: The level of Phase $V$ Storage operations and direct support personne 's knowledge, skill and abilities are adequate to operate in compliance with the CWC operating and administrative procedures, as evidenced by selected interviews of personnel, review of examinations and examination results by the RT.

Note: For this review, interviews werf directed at operations support personnel's knowledge of the requirements in the recently implemented Interim Operational Safety Requirements (IOSR)

DATE: $5 / 15 / 97$

FINDING STATEMENT: Interviews of persdnnet who had been provided training on the Interim Safety Basis indicated gen $\$$ ral level of knowledge weaknesses in two specific areas:

* Five of 5 personne interviewed fould not explain the Restricted Mode of facility operation.

* Five of 5 personnel interviewed fould not explain the administrative controls established in the IOSR All individuals were able to provide at least one administrative contfol.

DISCUSSION/CONCLUSION: The Interim Safety Basis and associated IOSRs were implemented and general training was pfovided to a large number of personnel utilizing the same lesson plan. No exfminations were given to establish the level of knowledge retention for the thaining. The Central Waste Complex Readiness Team interviewed selected op prations personne1, but did not interview operations support personnel

Central Waste Complex management has ndt clearly established level of knowledge expectations for operations fupport personnel in the area of IOSRs nor has action been taken to determine the current level of knowledge.

RECOMMENDATION: Define level of knowl dgge expectations for the Interim Safety Basis and related IOSRs for operations support personnel. Provide training to designated personnel and test their knowledge with examinations or interviews.

\section{RESOLUTION:}

SIGNATURES:

TEAM MEMBER:
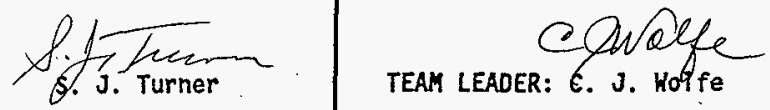

\begin{tabular}{l|l} 
THC. & TEAM LEADER: \\
\hline &
\end{tabular}


FINDING NUMBER: F.8-1.1

ORR FINDIIIG FORM

CORE REQUIREMENT NUMBER: 8.1 CORE REQUIREMENT STATEMENT:THERE IS AN ADEQUATE EMERGENCY PREPAREDNESS ORGANIZATION AND PROGRAM.

CRITERIA NUMBER: 4

CRITERIA STATEMENT: FACILITIES, EQUIPMENT, AND RESOURCES ARE IN PLACE AND ADEQUATE TO SUPPORT EMERGENCY RESPONSE OPERATIONS AND ENSURE THE PROTECTION OF ALL PERSONNEL (e.g. EMERGENCY OPERATIONS CENTER, BACKUP OR ALTERNATIVE FACILITIES, PRIMAPY AND BACKUP COMMUNICATION, ALARMS ADEQUATE TO NOTIFY PERSONNEL, TRANSPORTATION, MEDICAL TREATMENT, RESPIRATORY EQUIPMENT, EXPOSURE CONTROLS, INSTRUMENTATION TO MEASURE EXPOSURE, ETC.

CRITERIA NUMBER: 6 CRITERIA STATEMENT: HAZARDS ASSESSMENTS ARE PREPARED, DOCUMENTED, AND MAINTAINED WHICH CONSIDERS EMERGENCY EVENTS THAT COULD AFFECT CWC.

CRITERIA NUMBER: 7 CRITERIA STATEMENT: INDIVIDUALS AND ALTERNATES ARE DESIGNATED TO PERFORM ALL EMERGENCY ROLES USING CLEAR LINES OF SUCCESSION.

DATE: $\quad 5 / 16 / 97$

FINDING STATEMENT:

1) TWO-WAY RADIO SIGNALS ARE WEAK OR NOMEXISTENT IN SOME AREAS OF THE STORAGE BUILDINGS. THIS DEFICIENCY DOES NOT ENSYRE FULL COVERAGE OF THE FACILITY FOR NOTIFICATION OF PERSONNEL DURING EMERGEMCY CONDITIONS. (POST-START)

2) FACILITY EMERGENCY EQUIPMENT INVENTOHIES NEED UPGRADED AND LOCATIONS STATED IN THE BUILDING EMERGENCY PLAN ARE NOT \$PECIFIC. (PRE-START)

3) THE SPILL KIT INSPECTED EAST OF 2404 WB CONTAINED OUTDATED SIGNS. (POSTSTART)

4) THE CURRENT SOLID WASTE/BURIAL GROUND HAZARDS ASSESSMENT DOES NOT REFLECT THE ISB. (POST-START)

5) RESPONSIBILITIES FOR EACH PERSON IN HHE BUILDING EMERGENCY ORGANIZATION ARE NOT WELL DEFINED IN THE BUILDING EMERGEHICY PLAN. MORE DETAIL IS NEEDED TO ESTABLISH DESIGNATED DUTIES FOR EACH PO\$ITION OF THE ORGANIZATION. EXAMPLE: COMMUNICATOR AND RECORDER SHOULD BE SPE IFIED WITH DUTIES FOR EACH POSITION. (PRE-START)

\section{DISCUSSION/CONCLUSION:}

1) PERSONNEL RELY UPON TWO-WAY RADIOS FOR TIMELY COMMUNICATIONS WHILE WORKING IN THE STORAGE BUILDINGS. THE REDUCTION OF COMMUNICATION DURING EMERGENCY CONDITIONS PREVENTS TIMELY RESPONSE BY EMERGENCY PERSONNEL. MANY COMPLAINTS WERE STATED DURING THE EMERGENCY DRILL BY OPERATIONS MANAGEMENT AND NUCLEAR OPERATORS. FURTHER DISCUSSION ON COMMUUICATIONS MAY BE REFERENCED IN CORE REQUIREMENT 12.0. IT SHOULD ALSO BE NO ED THE FACILITY IS CURRENTLY PURSUING ANOTHER FREQUENCY FOR THE TWO-WAY RADIO SYSTEM THAT WOULD MINIMIZE OUTSIDE FACILITY INTERFERENCE. 
2) THE PERSONNEL PROTECTIVE EQUIPMENT TABLE IN THE BUILDING EMERGENCY PLAN STATES IN SEVERAL AREAS THAT PERSONNEU PROTECTIVE EQUIPMENT IS LOCATED AT CWC. THIS IS A GENERAL STATEMENT AND DOES NOT DIRECT PERSONNEL TO SPECIFIC AREAS TO OBTAIN EOUIPMENT AND MATERIALS. OBSERVITIONS OF SEVERAL SPILL KITS FOUND THE FOLLOWING DEFICIENCIES: SPILL CONTROL KITS ARE LOCKED WITH WIRE TIES WHICH CANNOT BE BROKEN WITHOUT TOOLS, PERSONNEL SHOULD BE ABLE TO BREAK AND OPEN THEM BY HAND. NOT ALL SPILL KITS HAVE INVENTORY SHEETS IN CABINETS. RADIOLOGICAL POSTING SIGNS ARE OUTDATED.

3) HSRCM ARTICLE 231.8 STATES THE ENTRANCE POINTS TO AREAS OF ONGOING WORK ACTIVITIES CONTROLLED FOR RADIOLOGICAL PURPOSES SHOULD STATE BASIC ENTRY REQUIREMENTS. IF A SPILL WAS TO OCCUR AT CWC, THE SIGNS IN THE SPILL KITS WOULD NOT STATE THE ENTRY REQUIREMENT (IE. RWP, RADIOLOGICAL WORKER TRAINING) FOR THE AREA, AND THUS VIOLATE HSRCM REQUIREMENTS. HSRCM ARTICLE 231.11 STATES THAT POSTING OF DOORS SHOULD BE SUCH THAT THE POSTINGS REMAIN VISIBLE WHEN DOORS ARE OPEN OR CLOSED.

4) THE CURRENT HAZARDS ASSESSMENT DOES NOT REFLECT ISB EVENT SCENARIO AND CONSEQUENCES. FOR EXAMPLE, THE MIXED WASTE DRUM FIRE BERYLLIUM CONCENTRATIONS ARE IN THE ISB BUT NOT IN THE CURRENT HAZARDS ASSESSMENT.

5) SPECIFIC REQUIREMENTS AND DUTIES ARE NOT DETAILED ENOUGH IN THE BUILDING EMERGENCY PLAN TO DEFINE AREAS OF RESPPNSIBILITY FOR EMERGENCY ORGANIZATION MEMBERS. MORE DETAIL IS NEEDED TO ESTABLISH DESIGNATED DUTIES FOR EACH

. POSITION OF THE ORGANIZATION. EXAMPLE: COMMUNICATOR AND RECORDER SHOULD BE SPECIFIED WITH DUTIES FOR EACH POSITION.

\section{RECOMMENDATION:}

1) UPGRADE THE CURRENT PORTABLE RADIO SYSTEM TO INCREASE SIGNAL STRENGTH TO COVER ALL AREAS OF THE FACILITY OR DESIIGN ANOTHER FORM OF TIMELY COMMUNICATIONS SYSTEM (i.e., PUBLIC ADPRESS SYSTEM ETC.)

2) UPGRADE EMERGENCY EQUIPMENT INVENTORIIES, ESTABLISH SPILL KIT NEEDS BASED ON HAZARD INVENTORY, AND REVISE THE BUILDING EMERGENCY PLAN TO GIVE SPECIFIC LOCATIONS OF EQUIPMENT.

3) INSPECT ALL SPILL KITS TO ENSURE PROPER SUPPLIES ARE PRESENT AND REPLACE OUTDATED SIGNS.

4) REVISE THE CURRENT HAZARDS ASSESSMENT, EMERGENCY PLAN AND EMERGENCY ACTION LEVELS TO REFLECT ISB CONTENT AS APPROPRIATE.

5) REVISE THE BUILDING EMERGENCY PLAN TO REFLECT SPECIFIC RESPONSIBILITIES OF INDIVIDUAL EMERGENCY ORGANIZATION MEMBERS.

RESOLUTION:

SIGNATURES :

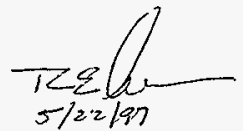

TEAM MEMBER:
R. E. ALLEN 
FINDING NUMBER: F.8-3.5.1

ORR FINDING FORM

CORE REQUIREMENT NUMBER: 8.3

CDRE REQUIREMENT STATEMENT: There is an adequate Environmental Protection organization and program.

CRITERIA NUMBER: 5

C\$ITERIA STATEMENT: A program, with procedures and training, is in place fo maintain hazardous material inventory controls, and to monitor and limit release of toxic chemical materials from Phase $V$ to the environment. Verify ipplementation in other CWC facilities.

DATE: May 20, 1997

FINDING STATEMENT: Hazards awareness $t$ CWC and preparations for Phase $V$ utilization do not give balanced attention to non-radioactive and radioactive sources in accordance with the possible waste stream inputs which will enter 2404-WA, $-W B, \&-W C$.

DISCUSSION/CONCLUSION: The facility las an excellent plan of the day, and pre-job safety briefing activities. However, safety compliance and environmental protection thought processes are concentrated on radioactive dose evaluation, and do not give suff cient attention to the specific needs of possible non-radioactive materials in the containerized wastes. Many of the radioactive wastes are co-mingled with organic and non-metallic materials which may be carcinogenic or poisonous if ingested/inhaled.

This finding is based primarily on observation of participants' reaction to critiques of the emergency drill held on May 14, 1997, from 9:00 to 10:00 AM. Responding support personnel (HPTs and IH) began surveying possible impacts from simulated spill in the building. Insufficient attention was made to use of suitable instrumentation to determ ne exposure to toxic chemical materials.

Drill scenario included information that container waste included nitric acid, tri-butyl phosphate and other organic solvents. No effort was made to search the facility records or the SWITS dat base to determine if reportable quantities were released, or if specifl health prevention measures would be needed for the affected operator(s). Immediate response personnel in the drill did not appear to be aware of these needs either, especially in the post-dritl critique.

RECOMMENDATION: CWC management needs to evaluate the hazards communication segments of the current training progham, to ensure that sufficient attention is provided for the operators to understand the possible dangers due to materials/wastes in received containets; including legacy wastes, and can identify unsafe or non-compliant situdtions and appropriate response actions for them.

RESOLUTION:

SIGNATURES:

TEAM MEMBER:

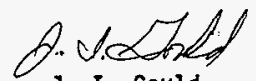

J. I. Gould

$5-22-97$

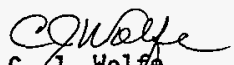

TEAM LEADER: C. 3 , Hol te 


\section{ORR FINDIIIG FORM}

FINDING NUMBER: F.8-8.1

CORE REQUIREMENT NUMBER: 8.8 CORE REQUIREMENT STATEMENT: Industrial hygiene and safety programs, policies, and procedures have been developed which are consistent with the hazards present or anticipated in the working environment as well as with DOE Orders and OSHA stardards. The overall program is effectively managed to promptly address and remedy hazards, and systems are in place to communicate information to workers in order to prevent occupational injuries and illnesses.

CRITERIA NUMBER: 5 CRITERIA STATEMENT: Sufficient work place surveillance exists to seek and track safety and health hazards. Regutar and periodic audits are conducted to assess work place conditions.

CRITERIA NUMBER: 6 CRITERIA STATEMENT: Noncompliant conditions are documented, corrective action dates established, and tracking programs implemented to assure prompt abatement of observed hazards.

DATE: $05 / 15 / 97$

FINDING STATEMENT: A documented prelimihary hazards assessment of the 2404 series storage buildings has not been cofapleted for illumination requirements.

\section{DISCUSSION/CONCLUSION:}

WHC-CM-5-36, Chapter 1-10, Section WKS 3, Paragraph 3.2 states, "Before each new occupancy or change of application for a facility or building, conduct a review to ensure that the facility is ready to safely accommodate the people and the intended use. Ensure that the following are among items addressed: Fire Protection; lighting; Life Safety dode Compliance; Industrial Hygiene; Fire Department/Ambulance response; Traffic Safety." Paragraph 3.3 goes on to state the minimum information to be included in the report. Industrial Safety, Industrial Hygiene, and Fire Protection personnel have walked down the buildings and have identified many safety concerns which have already been corrected as punch list items. The process needs to be formalized and properiy documented to determine "safe to operate condition" and to show compliance with the requirement.

\section{RECOMMENDATION:}

Perform and document an illumination survey for the 2404 series storage buildings prior to use.

\section{RESOLUTION:}

Survey of buildings complete and documentted prior to close out of the ORR.

SIGNATURES:

TEAM MEMBER:

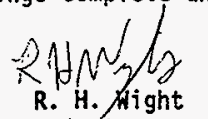

$5 / 22 / 57$
TEAM LEADER:

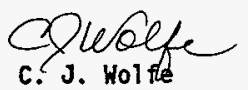


FINDING NUMBER: F.9.1.1

CORE REQUIREMENT NUMBER: 9 CORE REQUIREMENT STATEMENT: A ROUTINE AND EMERGENCY OPERATIONS DRILL PROGRAM, INQLUDING PROGRAM RECORDS, HAS BEEN ESTABLISHED AND IMPLEMENTED.

CRITERIA NUMBER: 1 CRITERIA STATEMENT: THE DRILL PROGRAM ADEQUATELY PLANS, SCHEDULES, PREPARES, CONDUCTS, CRITIQUES, AND DOCUMENTS DRILLS.

DATE: $5 / 16 / 97$

FINDING STATEMENT:

1) PERFORMANCE OF THE ORR EMERGENCY PRAPAREDNESS DRILL WAS LESS THAN ADEQUATE IN THREE AREAS: DRILLMANSHIP, COMMAND AND CONTROL AND RADIOLOGICAL CONTROL. (PRE-START)

2) A PLAN NEEDS TO BE DEVELOPED FOR IMAROVING THE EMERGENCY PREPAREDNESS PROGRAM AT CWC. (POST-START)

$\because$ DISCUSSION/CONCLUSION:

1) AN OPERATIONAL READINESS REVIEH EMEAGENCY PREPAREDNESS DRILL WAS PERFORMED ON 5/14/97. THE OBSERVATIONS AND DEFIC ENCIES NOTED INDICATED TO THE ORR TEAM THAT CWC PERSONNEL WERE NOT ADEQUATELY PREPARED TO DEAL WITH THIS EMERGENCY SITUATION. SEE ATTACHED INFORMATION.

2) AN OPERATIONAL READINESS REVIEW EMEHGENCY PREPAREDNESS DRILL WAS PERFORMED ON 5/14/97. THE OBSERVATIONS AND DEFIC IENCIES INDICATED TO THE ORR TEAM THAT CWC PERSONNEL WERE NOT ADEQUATELY PREPARED TO DEAL WITH EMERGENCY SITUATIONS. ACTIONS TAKEN BY THE EMERGENCY ORGANIZATION DURING THE EMERGENCY DRILL DID NOT MEET EXPECTATIONS OF THE ORR TEAM, FINDINGS BY THE RECENT FEB ASSESSMENT FOUND SIMILAR PROBLEMS. OTHER FINDINGS INCLUDE INFORMATION ABOUT EMERGENCY DRILL CRITIQUES IS NOT DISSEMINATED TO ALL AAPROPRIATE PERSONNEL AND SOME EMERGENCY DRILLS EXAMINED WERE NOT FORWARDED TO SITE EMERGENCY PREPAREDNESS PERSONNEL WITHIN THE THO WEEK SPECIFIED IN HNF-PR-000424.

\section{RECOMMENDATION:}

1) PERFORM AND DOCUMENT AN ADDITIONAL AMERGENCY ORILL FOR THE ORR TEAM.

IN PREPARING FOR THIS EXERCISE, THE ORG TEAM ANTICIPATES THAT CWC WILL PERFORM AND DOCUMENT A CRITIQUE OF THE PREVIOUS DRILL, AT LEAST ONE TABLETOP EXERCISE, AND SEVERAL PRACTICE DRILLS. IMPROVEMENTS ARE EXPECTED BY PERSONNEL PARTICIPATING IN THE DRILL AND BY PERSONNEL CONDUCTING THE DRILL.

2) DEVELOP AND ACCOMPLISH A PLAN FOR INPROVING OVERALL CASUALTY CONTROL AND TRAINING FOR CASUALTY CONTROL. IMPROVEMENTS SHOULD INCLUDE PERFORMANCE BASED TRAINING FOR PERSONNEL DEVELOPING AND OONDUCTING DRILLS AND FOR PERSONNEL PARTICIPATING IN THE DRILLS, INSTRUCTION IN DRILLMANSHIP AND SIMULATION FOR 
PARTICIPANTS AND TRAINERS, FULLY DEVELOPED ROSTERS AND TRAINING PLANS FOR EMERGENCY ORGANIZATION PERSONNEL (RECORDERS, COMMUNICATORS, SUPPORT STAFF ETC.), AND ESTABLISHING EMERGENCY EQUIPMENT LOCATIONS ADEQUATELY STOCKED AND PROTECTED FROM DAMAGE CAUSED BY WEATHER, RODENTS AND VANDALISM. OTHER RECOMMENDATIONS ARE TRANSMIT INFORMATI IN FROM POST DRILL CRITIQUES TO PERSONNEL BY PERFORMING ANY OF THE FOL OWING: REQUIRED READING, ALL PLANT MEETINGS, SAFETY MEETINGS, STAFF MEET ILS, INTER-PLANT TRANSMITTAL AND SUBMIT RE AND POST EMERGENCY DRILL REPORTS WT THIN THE SPECIFIED TWO WEEK PERIOD. RESOLUTION:

SIGNATURES:

TEAM MEMBER:

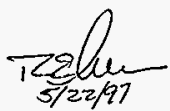

R. E. Allen

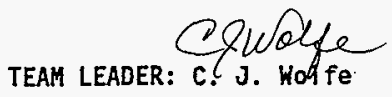

CWT PROJECT W-112/1SB ORR REPORT HNF-SD-WM-RRR-O12

REV. 0

MAY 22, $1997^{\circ} 35^{5}$ 
An Operational Readiness Review Emergency Preparedness Dri11 was performed on $5 / 14 / 97$. The following items have been determined less than adequate and actions will be required by the facility for closure.

\section{1) DRILLMANSHIP LESS THAN ADEQUATE.}

* Safety Sensitivity

* Assume drill is real and act accordingly until instructed by controlier

* Dri11 evaluation team needs to be traiped (proper conduct during dri11 etc.)

* Controllers were inadequately prepared (proper briefing before drill etc.)

* Identify exempt personnel before dri17 is performed

\section{2) COMMAND AND CONTROL NEED IMPROVEMENT.}

* BED \& ICP split control of event

* Roles \& responsibilities were not defihed

* Communication system was unreliable (ephance system)

* Communication practices need improvement (Repeat back, professionalism)

* Bed identification poor

* Failure to use SW-001-310 "Respond to Radioactive Mixed Waste Or Highly Toxic Waste Spi11"

3) RADIOLOGICAL CONTROL'S LESS THAN ADEQUATE.

* Contamination control practices need improvement

* RCT personnel need better knowledge of facility

* Personnel assume too many situations were simulated

* Timely notification to RCT MGR need's improvement

* Chemical hazards were not identified in detail

The observations and deficiencies noted above indicate to the ORR team that CWC personnel are not adequately prepared to deal with emergency situations. The corrective actions will require a combination of short term and longer term activities. Consequent1y, the ORR Team is assigning one prestartup item and one poststartup item.

\section{Prestartup Item:}

Prepare for and conduct an emergency dri 11 for the ORR Team.

In preparing for this exercise, the ORR Team anticipates that CWC wiTl perform and document a critique of the previous drill, at least one table top exercise, and several practice drills. mprovements are expected by personnel participating in the drill and by personnel conducting the dritl.

Poststartup Item: 
Develop and accomplish a plan for improving overall casualty control and training for casualty control.

The improvements should include training for personnel developing and conducting drills and for personnel participating in the drills, instruction in drillmanship and simulation for partikipants and trainers, fully developed rosters and training plans for casualty pupport personnel (recorders, communicators, support staff etc.), and establishing emergency equipment locations adequately stocked and protected from damage caused by weather, rodents and vanda 7 ism.

If you have any questions feel frep to call Ron wight at 376-2647 or Rich Allen at 373-5344. 
FINDING NUMBER: F.12.1.1

CORE REQUIREMENT NUMBER: 12

ORRFIN DING FORM

implementation status for DOE Order 5 \$80.19, Conduct of Operations

Requirements for DOE Facilities, is apequate for operations.

CRITERIA NUMBER: 1

CRITERIA STATEMENT: The facility has

implemented the WHC-CM-5-34 Conduct of Operations chapters. Specifically, for this finding, chapter 3.14 , Lockout and Tagout.

DATE: $\quad 5 / 15 / 97$

FINDING STATEMENT: DOE-RL-SOD-INST-L BT.001 Rev 1 , Section 4.1 requires, in part, that the controlling organizatipn's procedure specify how and where an authorized worker's lockout/tagout is applied. Section 2.9 (Lockout and Tagout) of RFSH-200. (the controlling prganization's procedure which replaced WHC-CM-5-34, Section 3.14) does not specify how and where an authorized worker's lockout/tagout is applied. Bpecifically, instructions are not included for how and where an authoriked worker's lockout/tagout is applied by itself (without documentation).

DISCUSSION/CONCLUSION: Section 3.14 of WHC-CM-5-34 has been replaced by RFSH200, Section 2.9. Some problems occupred with this transition:

* Responsibility is not defined in facility procedures for determining whether or not the 8 requirements defined in DOE-RL-SOD-INST-L\&T.001 Rev I for using an authorized worker's lockout/tagout by itself are met. Interviews of personnel involvep in the lockout/tagout process indicate confusion as to who is responsiple for this determination and how it is to be controlled.

* Field personnel interviewed were not aware the controlling procedure for Lockout and Tagout had been chahged nor could they readily access the procedure when informed of the thange.

Note: This is an administrative item in that the previous and replacement procedures are the same in content.

RECOMMENDATION: Establish in facility procedures how and where authorized worker's lockout/tagout is to be applied without documentation and establish clear responsibility for determining if the 8 requirements are met.

\section{RESOLUTION:}

SIGNATURES:

TEAM MEMBER:

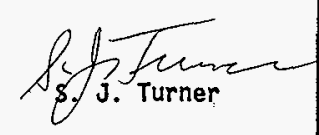

TEAM LEADER:

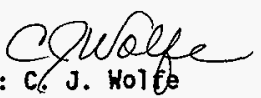


FINDING NUMBER: F.15.2.1

CORE REQUIREMENT NUMBER: 15

ORR FINIING FORM

systems and procedures as effected by facility modifications, are consistent with the description of the facility, procedures, and accident analysis

included in the safety basis.

CRITERIA NUMBER:2

CRITERIA STATEMENT: Operations,

maintenance, surveiliance, and administrative procedures implement the changes made in the approved safety basis resulting from the facility modifications.

DATE: May 20, 1997

FINDING STATEMENT: The Central Waste Complex Interim Safety Basis(HNF-SD-WMISB-007 Rev.1) Administrative IOSR\#6.2.2.1 which requires "lines of authority, responsibility, and communication are sstabi ished and defined for the highest management levels through intermediate leveis to, and including, all safety and operating organization positions". RUST correspondence RFSH-9656450, dated December 19,1996 did not provide suffidient information to determine how this IOSR was being complied with by the fadility.

DISCUSSION/CONCLUSION: Administrative JOSRs must be satisfied with the same level of rigor and structure that an engineered barrier would be for proper management of the hazard to satisfy nudlear safety requirements for a category 2 facility, The annual ietter to DOE-AL RFSH-9656450 transmitted a simple organizational block diagram with referenced sections of WHC-CM-5-34 and WHCCM-5-36 does not provide sufficient defail to assure that the requirement of the IOSR for clear and concise lines of authority, responsibility, and communication from top to bottom exist for personnel responsible for proper management of the hazards as defined in the ISB.

RECOHMENDATION: Prepare an operating document that provides the detailed responsibilities, communications, and lines of authority as delineated in the IOSR. This would be a nuclear safety gased document that would describe how. the organization functions to meet it's responsibilities for safe management of the hazards. The document needs to include how potential organizational changes are to be evaluated to assure that proper management of the hazard and safety of the worker per the CWC Interim Safety Basis are satisfied..

RESOLUTION:

SIGNATURES:

TEAM MEMBER: William W Bowen

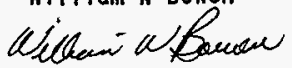

TEAM LEADER:

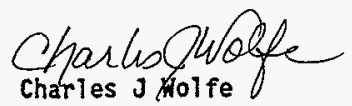

CWC PROJECT W-112/ISB ORR REPORT HNF-SO-WM-RRR- 12 REV. 0

MAY 22, 1997

Page 39 
ORR FINIING FORM
FINDING NUMBER:

CORE REQUIREMENT NUMBER:15

CORE REQUIREMENT STATEMENT: The facility systems and procedures as effected by facility modifications, are consistent with the description of the facility, procedures, and accident analysis included in the safety basis.

CRITERIA NUMBER: 3

CR. TERIA STATEMENT: An adequate process has been implemented to ensure that dodumentation for systems critical to and support the safety of the facility exift, reflect the current facility modifications and they are reviewed for facility safety impact, and are kept current.

DATE: May 20, 1997

FINDING STATEMENT: The Solid Waste Infdrmation and Tracking System (SWITS) provides the inventory basis by which facility hazards, both radiological and chemical are evaluated to ensure a fac 7 ity's design and procedural controis are adequate to meet the Timits imposed by the Authorization Basis documents. However SWITS is not being managed as nuclear safety information system.

DISCUSSION/CONCLUSION: The SWITS syster is the primary tool that implements or provides data for the safe management of solid waste at the Central Waste Complex. It incorporates and/or satis ies requirements for Unreviewed Safety Questions (5480.21), Technical Safety fequirements (5480.22), Nuclear Safety (5480.23), and Criticality $(5480.24)$ byt is being managed as a programmatic data base. It is not being subjected to the reviews that a nuclear safety technical based system is for hazard management. SWITS does have a well documented change control process that includes administrative procedures and change board. It also has a well defined team that assures currency and usability for it's many customers. It was not apparent that programming had been validated as appropriate for a nudiear information data base.

RECOMMENDATION: Manage SWITS as a techr ical based nuclear safety system/tool to include USQ change control and ackndwiedge that in the appropriate sections of WHC-CM-5-34. Incorporate the current guidance documents for SWITS (HNF-IP1097 and HNF-IP-1259) appropriately into the facility documentation.

\section{RESOLUTION:}

SIGNATURES:

TEAM MEMBER: William $W$ Bowen

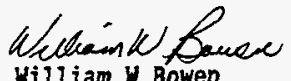

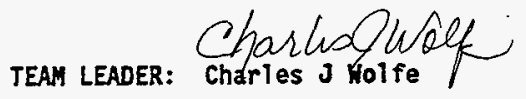

REV. 0

MAY 22, 1997

Page 40 
FINDING NUMBER: F.15.4.1

ORR FINDIN FORM

CORE REQUIREMENT NUMBER: 15 CORE REQUIREMENT STATEMENT: The facility systems and procedures as effected by facility modifications, are consistent with the description of the facility, procedures, and accident analysis in the safety basis.

CRITERIA NUMBER: $4 \& 9$

CRITERIA STHTEMENT: \#4) Orawings and other documentation relied upon for operations and maintenance activities are consistent with the new existing plant copfiguration. \#9) The Functional Design Criteria for modifications was utifized by the construction vendors for design, fabrication, and installation(includes ATPs and OTPS).

DATE: May 20,1997

\section{FINDING STATEMENT:}

1.) The Fire Suppression system sprinklers are not installed per manufacturers data nor meet the installation drawing H-2-823231.

2.) The components of the fire suppressipn system that are used for activation of the sprinklers do not have the proper labeling required per 5480.19.

3.) Minimum and maximum pressure ranges for supervisory air pressure and fire main water pressure specified in the CWC furveillance procedure are broader (less restrictive) than the ranges speciffed in the Fire Department procedure used for testing the 2404 series building fire suppression systems.

\section{DISCUSSION/CONCLUSION:}

1.) It is difficult to determine the fire suppression headers and sprinkiers as-installed locations due to their elevafion off of the floor. It appears that the headers may not be installed to permit proper water flow after discharge and many sprinklers are not insfalled per the design which would hamper it's coverage during activation.

2.) The components of the fire suppressioh system that is managed be the Fire Department are not labeled or identified consistent with the balance of the facility. Discussions. with staff indicated that the Fire Departanent wants to manage their way and not incorporate facifity best practices resulting in a difference between the Memorandum of Understanding between the Hanford Fire Department and the Solid Waste Organizatipn.

3. CHC procedure SH-040-043 establishes the minimum and maximum values for supervisory air pressure at 32.5-50 psig. Fire Department test procedure RFAR 2740 establishes the acceptable range at $66-44$ psig. 043 establishes the range for water pressure at $75-150$ psig afd RFAR 2740 establishes the range as 86-105 psig. 


\section{RECOMMENDATION:}

1.) Conduct a detailed inspection the fire suppression system headers and sprinklers to determine if it is both designed and installed correctly.

2.) The Memorandum of Understanding between Sol id Waste Management and the Hanford Fire Department effectively fontracts with the Fire Department to test and maintain the fire suppression syttems at the storage facilities. The Central Waste.Organization is stili operations, testing and maintenance. their contracted portions of the sys results of testing to all appropriat engineering, maintenance, safety) and for proper retention. The MOU also nfeds to be amended to include the 2404 facilities.

3) Review procedure and update accordingly.

\section{RESOLUTION:}

As of this date the Solid Waste Faci initiated a thorough review of the $f$ able to determine that the piping ha and the spacing between sprinklers do the functionality of sprinklers that

SIGNATURES:

TEAM MEHBER: William $W$ Bowen fesponsible for system performance, both Request the Fire Department to 7 abe? ems correctly, prepare and present the facility organizations(operations, provide the test data to the facility

ity Engineering Organization has re suppression system. They have been been installed with the correct slope es meet NFPA requirements. Review of are adjacent to structures is continuing.

TEAM LEADER: Chatries $\mathrm{J}$ holfe 
APPENPIX B

\section{OBSERVATIONS}




\begin{tabular}{|c|c|c|}
\hline & Project $W-112 / C W C$ ISB ORR Master of & servations List \\
\hline No. & DESCRIPTI & bN \\
\hline 1.8 .1 & Areas of inattention to details wer & observed. \\
\hline 1.8 .2 & $\begin{array}{l}\text { Management involvement is needed in } \\
\text { and equipment conditions. }\end{array}$ & minor process improvement \\
\hline 1.8 .4 & * Good response to hydraulic spill. & * \\
\hline 1.8 .5 & * Workers demonstrated concern for & afety. * \\
\hline 4.3 .1 & $\begin{array}{l}\text { Upon reviewing the ISB and supporti } \\
\text { appears to be an opportunity to enh } \\
\text { supporting documentation. }\end{array}$ & $\begin{array}{l}\text { ig documentation, there } \\
\text { ance currency in the }\end{array}$ \\
\hline 4.3 .2 & $\begin{array}{l}\text { Upon reviewing the } S W-100-110 \text { under } \\
\text { to be an opportunity to reword the } \\
\text { clear the intent of the caution. }\end{array}$ & $\begin{array}{l}\text { flammables, there appears } \\
\text { faution to make it more }\end{array}$ \\
\hline 4.3 .3 & $\begin{array}{l}\text { Upon reviewing the } S W-100-110 \text { proce } \\
\text { the aisle widths and drivers which }\end{array}$ & $\begin{array}{l}\text { lure, it was confusing as to } \\
\text { are to be applied. }\end{array}$ \\
\hline 4.6 .1 & $\begin{array}{l}\text { * The facility is to be commended of } \\
\text { and application in the field. * }\end{array}$ & its attention to safety \\
\hline $8-1.4 .1$ & $\begin{array}{l}\text { UTILITY DISCONNECTS LISTED IN THE B } \\
\text { NOT DESIGNATED BY I.D. NUMBERS. }\end{array}$ & ILDING EMERGENCY PLAN ARE \\
\hline $8-1.4 .2$ & $\begin{array}{l}\text { SITE EVACUATION SIRENS ARE NOT DISC } \\
\text { EMERGENCY PLAN }\end{array}$ & SSSED IN THE BUILDING \\
\hline $8-3.1 .1$ & $\begin{array}{l}\text { There is no current program in plac } \\
\text { possible contamination release from } \\
\text { or the trenches which may supply wa }\end{array}$ & $\begin{array}{l}\text { which can monitor only } \\
\text { either Phase } V \text { buildings, } \\
\text { tes to Phase V. }\end{array}$ \\
\hline $8-3.2 .1$ & $\begin{array}{l}\text { The Phase } V \text { input waste streams can } \\
\text { wholesale, whether the facility (bu } \\
\text { would contain sufficient source mat } \\
\text { registration of the Phase } V \text { buildin } \\
\text { item from the PRE-ORR facility mana }\end{array}$ & $\begin{array}{l}\text { not be fully characterized } \\
\text { ldings } 2404-W A \text {, } W B \text {, } W C \text { ) } \\
\text { rials to require } \\
\text { as a whole. This is an } \\
\text { gement review. }\end{array}$ \\
\hline $8-3.2 .2$ & $\begin{array}{l}\text { The Phase } V \text { input waste streams can } \\
\text { SWD scope of responsibility under } t \\
\text { accept a } 11 \text { wastes generated on site } \\
\text { container meets the published Hanfo } \\
\text { EP-0063-4 (soon to be rev 5). Also } \\
\text { accept wastes generated at selected } \\
\text { provided that they meet the } 0063 \text { ac }\end{array}$ & $\begin{array}{l}\text { not be fully characterized; } \\
\text { ie PHMC contract is to } \\
\text { provided that each } \\
\text { d Waste Acceptance Criteria } \\
\text { the CWC is directed to } \\
\text { other DOE facilities, } \\
\text { eptance criteria. }\end{array}$ \\
\hline $8-3.4 .1$ & $\begin{array}{l}\text { The Phase } V \text { buildings do not have a } \\
\text { CWC management has chosen to operat } \\
\text { Wide PP/W-M program. Phase } V \text { will } \\
\text { stabilization of container wastes t } \\
\text { availability to the environment, or } \\
\text { facility worker exposure/dose. All } \\
\text { performed by either the generator o } \\
\text { facility or by SWD Generator servic }\end{array}$ & $\begin{array}{l}\text { separate PP/W-M plan. The } \\
\text { under the Hanford Site- } \\
\text { pot perform any } \\
\text { reduce toxicity, } \\
\text { reduction of potential } \\
\text { similar actions are } \\
\text { the container, by the WRAP } \\
\text { s. }\end{array}$ \\
\hline
\end{tabular}


8-3.10.1 This criterion addresses the genera adequacy of the records management system, from the environtental perspective. CWC EC maintains an extensive regulatory if sues file, as required by CM-7-5 for a1] facilities on site.

Data retrieval is the primary requifement. Several items were requested from different sources, ald a road map was given to this ORR member with which to find the requested information; some of which were located.

As a secondary issue, the recording criteria for generating records was pursued; this path was ess satisfactory. Instructions to record data are on post of the Plant Operating Procedures for a specific job task. Those POPs actually examined stated (in many cases) tha the data sheet was to be given to the first line supervisor or cog manager. This person was assumed to forward those record of environmental comp ?iance nature to the CWC EC mandger. The Writers Guide for POPS was exam ned, under several headings of data sheets and records; it did fot have a similar instruction to incorporate the forwlrding to the CWC EC manager. This is an editorial defifiency, which apparently has been operationally closed in the paft by the general expertise of the Procedure writers, without the specific guidance. CWC EC can ca11 upon other environmental support organizations at T-Plant, 222-S Laboratory and the central Environmental Services organization at 2440 Stevens.

8.3.14.1 * The CWC Environmental Compliance prganization is very aggressive in doing facility inspections, and maintains a log of the results in the organization ffice in M0-720. When the workload of the normally a signed staff is excessive, CWC EC can ca11 upon other environmental support organizations at T-Plant, 222-S Laboratory and the central Environmental Services organization at 2440 Stevens to assist in the inspections. *

8-10.7.1 * The configuration control and chahge process for Plant Operations Procedures as a good praftice.*

8-11.1.1 A unique records management program for Solid Waste Management that addresses all responsibilities document controls, storage, and retrievability does nof exist. 
The following deficiencies were not d during reviews of documentation and field observation of work in progress: 1) CWC Operators are reporting out of pecification surveillance conditions to the Operations Team Leader. However, they are not red circling these readings as required by 5-34, Section 3.7, para. 4.6. 2) Team Leaders ar not logging in the Facility Logbook periodic observations of operator rounds as required by 5-34, Section 3.7, para 4.6. 3) SW-040-043, Inspect the CWC and Sodium Storage Building, establishes an expectation that communications be paintained with operations personnel in the complex. However, communications with these personnel is difficult because of shared radio channels, radios not working properly. and operations personnel not maintaining beepers on or with adequate batterifs. (Finding F.8.1.4.2 specifically addresses problems wit radio communications.) 4) 5-34, Section 3.5, Rev 2, para. .0 cites SWD facilities as Hazard Category 3 vice Hazard Categpry 2 as indicated in the Interim Safety Basis document. 5) Ppsted criticality prevention specifications in the storage build ngs are not being controlled as operator aids. Operafions personnel are relying on an individual's knowledge and quprterly inspections by compliance personnel to ensure the PS postings are current. 6) Non-active alarms on the CAM ala m panel for the 2403 series buildings are not labeled as required by $5-34$, Section 3.16 , 5.0 .1 . 
OBSERVATION NUMBER: 0.1 .8 .1

CORE REQUIREMENT NUMBER: 1.0

CORE REQUIREIENT STATEMENT: There are adequate and correct procedures and safety limits for operating the process systems and utility systems.

CRITERIA NUMBER: 8

CRITERIA STATEMENT: Are personnel complying with procedures

DATE: $5 / 20 / 97$

OBSERVATION STATEMENT: Areas of inattention to d\&tails were observed.

DISCUSSION/CONCLUSION: The following items were dbserved and attributed to inattention to details

- A fire extinguisher was found missing a seł1 at FS-22.

- Floor quadrant signs in 2403-WD south end $f f$ the building were covered or rubbed off.

- Procedure SW-040-043 step 49 incorrectly identifies going to step 51 instead of step 50.

- Spill kit inventory sheets have the nylon ftrap section left blank instead of checking or putting "N/A".

- Several Radiological posting signs were observed to have inserts not properly in place on the signs. The top inserts are falling belind the bottom insert inside of the sign. 2403-WB had two administrative mistakes on the survey postings at the building which the RCT corrected.

RECOMMENDATION: Re-enforce that details matter $w$ th all personnel.

RESOLUTION:

SIGNATURES:

TEAM MEMBER:

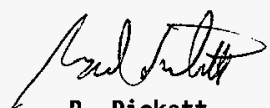

R. Pickett 
OBSERVATION NUMBER: 0.1 .8 .2

CORE REQUIREMENT NUMBER: 1.0

CORE REQUIREMENT STATEMENT: There are adequate and correct procedures and safety limits for operating the process systems and utility systems.

\section{CRITERIA NUMBER: 8}

CRITERIA STATENENT: Are personnel complying with procedures

DATE: $5 / 20 / 97$

OBSERVATION STATEMENT: Management involvement is needed in minor process improvement and equipment conditions.

DISCUSSION/CONCLUSION: The following items were observed and indicated management needs more involvement in minor process improvements.

- A temporary label has been in place over 5 months at FS-2I.

- RCT vehicle has a flag on it which is connected using duct tape.

- Truck H0-68B-4640 has a rope attached to the door strap to make it easier to close. The rope is taped together with HP tape.

RCT indicated that a sign was being made for 2403-WB which would say something like contact RCT for current radiological dose rates because the area dose rates in the building were changing daily.

The RCT had to use a trailer which happen to be in the area to shield his GM. to keep the background below 200 cps for reading his smears.

An operator indicated that the scanners have a problem reading the 7 abels in the direct sunlight.

The truck used to deliver drums did not have a radio to report a hydraulic leak and spill.

Drum labels are frequently coming loose or coming off and their verbal policy is not reflected in their procedures.

Fire extinguisher tags come off frequently due to the wind and their locations. Loose scrap banding is piled on the floor throughout the active buildings for re-use. A bin or other container could be used to store the material.

The above items are minor in nature but indicate a need to focus a little more attention to what may improve their work process.

RECOMMENDATION: Management work with operators, truck drivers, RCTs, and other bargaining unit personnel to quickly resolve minor problems and create positive dialogue for process improvement.

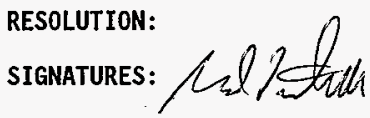

TEAM MEMBER: R. D. Pickett
TEAM LEADER: c J. Wolfe 
OBSERVATION NUMBER: 0.1 .8 .4

CORE REQUIREMENT NUMBER: 1 CORE REQUIREMENT STATEMENT: There are adequate and correct procedures and safety limits for operating the process systems and utility systems.

CRITERIA NUMBER: 8

CRITERIA STATEMENT: Are personnel complying with procedures

DATE: $5 / 20 / 97$

OBSERVATION STATEMENT: Correct response to hydraulic spill.

DISCUSSION/CONCLUSION: The operators, truck driver, and RCT responded appropriately and per procedure to a hydraulic leak on the truck.

\section{RECOMMENDATION:}

RESOLUTION:

SIGNATURES:

TEAM MEMBER:

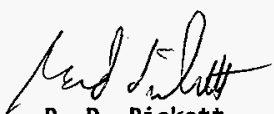

R. D. Pickett
TEAM LeADER: cywole 
ORR OBSERVATION FORM

OBSERVATION NUMBER: 0.1 .8 .5

CORE REQUIREMENT NUMBER: 1

CORE REQUIREMENT STATEMENT: There are adequate and correct procedures and safety limits for operating the process systems and utility systems.

CRITERIA NUMBER: 8

CRITERIA STATEMENT: Are personnel complying with procedures

DATE: $5 / 20 / 97$

OBSERVATION STATEMENT: Workers demonstrated concern for safety

DISCUSSION/CONCLUSION: The workers demonstrated that they were concerned about safety of themselves and others and worked effectively together in the following examples.

RCT reminded someone to stay back from some drums to minimized exposure.

An operator was deliberate and cautions about accessing areas were snakes and spiders have been a problem in the past.

An operator identified a hazard during the spill drill which had not been considered during the development of the drill, the fork truck was running tipped over on its side introducing an fire and fume hazard.

- An operator, RCT, and driver worked with each other effectively while moving drums.

RECOMMENDATION:

RESOLUTION:

SIGNATURES:

TEAM MEMBER:

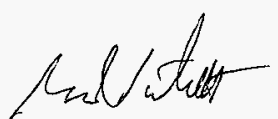

R. D. Pickett

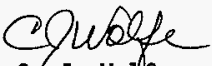

TEAM LEADER: c. J. Wolfe

CWT PROJECT W-112/ISB ORR REPORT HNF-SD-WM-RRR-012

REV. 0

MaY 22, 1997 Page 50 


\section{ORR OBSERRVATION FORM}

OBSERVATION NUMBER: 0.4 .3 .1

CORE REQUIREMENT NUMBER: 4

CORE REQUIREMENT STATEMENT: Facility safety documentation is in place that describes the "safety envelope" of the facility. The safety documentation should characterize the hazards/risks associated with the facility and should identify mitigating measures(systems, procedures, administrative controls, etc.) that protects workers and the public from those hazards/risks. Safety systems and systems essential to worker and public safety are defined and a system to maintain control over the design and modification of facilities and safety related utility systems is establi shed.

CRITERIA NUMBER: 3

CRITERIA STATEMENT: Documentation provides for the protection of the worker and the public.

\section{DATE: $5-21-97$}

OBSERVATION STATEMENT: Upon reviewing the ISB and supporting documentation, there appears to be an opportunity to enhance currency in the supporting documentation.

DISCUSSION/CONCLUSION: Current ISB accident scenarios confirm that criticality is not credible based upon unmitigated accidents. The CSER and CPS supporting that conclusion is well documented in a generic sense. There is an opportunity to clarify facility unique configurations giving the user information that the upset conditions, both unmitigated and mitigated, are addressed.

RECOMMENDATION: Suggest as part of the upgrade program for authorization basis, revisiting critical supporting documentation on an annual basis similar to the requirement in DOE 5480.23 for maintaining currency.

\section{RESOLUTION:}

SIGNATURES:

TEAM MEMBER:

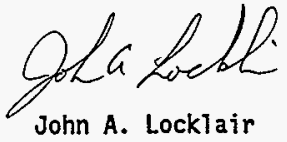

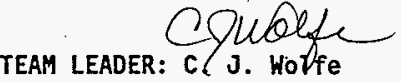




\section{ORR OBSERERATION FORM}

OBSERVATION NUMBER: 0.4 .3 .2

CORE REQUIREMENT NUMBER: 4

CORE REQUIREMENT STATEMENT: Facility

safety documentation is in place that describes the "safety envelope" of the facility: The safety documentation should characterize the hazards/risks associated with the facility and should identify mitigating measures (systems, procedures, administrative controls, etc.) that protects workers and the public from those hazards/risks. Safety systems and systems essential to worker and public safety are defined and a system to maintain control over the design and modification of facilities and safety related utility systems is establi shed.

CRITERIA NUMBER: 3 CRITERIA STATEMENT: Documentation provides for the protection of the worker and the public.

DATE: $5-20-97$

OBSERVATION STATEMENT: Upon reviewing the SW-100-110 under flammable there appears to be an opportunity to reword the caution to make it more clear the intent of the caution.

DISCUSSION/CONCLUSION: Under Section $E$ of the procedure Flammable acids are segregated from other flammable waste by a 3 -foot separation. This could be construed as other flammable acid containers which I don't believe is the intent.

RECOMMENDATION: Reword the caution to reflect the true intent.

RESOLUTION:

SIGNATURES:

TEAM MEMBER:

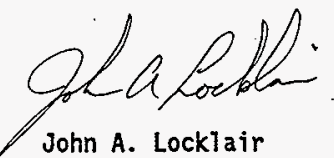

TEAM LEADER: C. J. Wo Vfe 


\section{ORR OBSERVATION FORM}

\section{OBSERVATION NUMBER: 0.4 .3 .3}

CORE REQUIREMENT NUMBER: 4

CORE REQUIREMENT STATEMENT: Facility safety documentation is in place that describes the "safety envelope" of the facility. The safety documentation shou?d characterize the hazards/risks associated with the facility and should identify mitigating measures(systems, procedures, administrative controls, etc.) that protects workers and the public from those hazards/risks. Safety systems and systems essential to worker and public safety are defined and a system to maintain control over the design and modification of facilities and safety related utility systems is established.

CRITERIA NUMBER: 3

CRITERIA STATEMENT: Documentation provides for the protection of the worker and the public.

DATE: $5-20-97$

OBSERVATION STATEMENT: Upon reviewing the SW-100-110 procedure it was confusing as to the aisle widths and drivers which to be applied.

DISCUSSION/CONCLUSION: There are instructions in the procedure for 3 foot segregation, 30 inch inspection aisies, and 3 foot aisles. It was a bit confusing to understand the requirement and application.

RECONMENDATION: Suggest rewording and clarifying requirements to include drivers such as RCRA, FHA, or ISB commitments.

\section{RESOLUTION:}

signatures:

TEAM LEADER: C. J. Wolfe

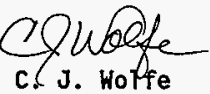




\section{ORR OBSERVATION FORM}

OBSERVATION NUMBER: 0.4 .6 .1

CORE REQUIREMENT NUMBER: 4

CORE REQUIREMENT STATEMENT: FaciTity safety documentation is in place that describes the "safety envelope" of. the facility. The safety documentation should characterize the hazards/risks associated with the facility and should identify mitigating measures (systems, procedures, administrative controls, etc.) that protects workers and the public from those hazards/risks. Safety systems and systems essential to worker and public safety are defined and a system to maintain control over the design and modification of facilities and safety related utility systems is established.

CRITERIA NUMBER: 6

CRITERIA STATEMENT: A program is in place that identifies workplace hazards and the information is used in planning and conducting facility work. Documentation provides for the protection of the worker and the public.

DATE: $5-20-97$

OBSERVATION STATEMENT: The facility is to be commended on its attention to safety and application in the field.

\section{DISCUSSION/CONCLUSION:}

RECOMMENDATION: There is a uniform commitment to worker safety that is implemented from senior management down to the worker level. The Job Hazards Analysis, Radiation Work Permit, ALARA program, Joint Review Committee, Safety Log Book, and safety council are mechanisms by which safety issues can be addressed. Additional oversight is provided by dedicated safety professionals involved in the development of workplans, procedures, and observation of work activities.

RESOLUTION:
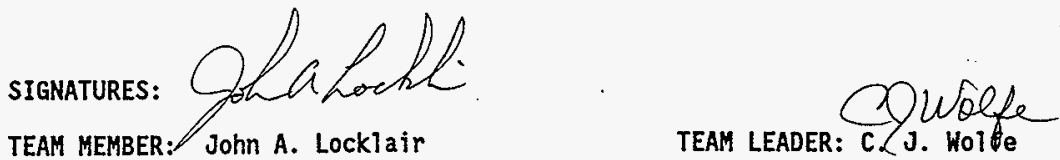


\section{ORR OBSERVATION FORM}

OBSERVATION NUMBER: $0.8-1.4 .1$

CORE REQUIREMENT NUMBER: $8-1$

CORE REQUIREMENT STATEMENT: THERE IS AN ADEQUATE EMERGENCY PREPAREDNESS ORGANIZATION AND PROGRAM.

CRITERIA NUMBER: $8-1.4$ CRITERIA STATEMENT: FACILITIES, EQUIPMENT, AND RESOURCES ARE IN PLACE AND ADEQUATE TO SUPPORT EMERGENCY RESPONSE OPERATIONS AND ENSURE THE PROTECTION OF ALL PERSONNEL (e.g., EMERGENCY OPERATIONS CENTER, BACKUP OR ALTERNATIVE FACILITIES, PRIMARY AND BACKUP COMMUNICATION, ALARM ADEQUATE TO NOTIFY PERSONNEL, TRANSPORTATION, MEDICAL TREATMENT, RESPIRATORY EQUIPMENT, EXPOSURE CONTROLS, INSTRUMENTATION TO MEASURE EXPOSURE, ETC.

DATE: $5 / 20 / 97$

OBSERVATION STATEMENT: UTILITY DISCONNECTS LISTED IN THE BUILDING EMERGENCY PLAN ARE NOT DESIGNATED BY I.D. NUMBERS.

DISCUSSION/CONCLUSION: DURING WALK AROUNDS WITH PLANT PERSONNEL IT WAS CLEAR THAT PERSONNEL COULD NOT DISCONNECT ELECTRICAL POWER TO MANY OF THE STORAGE BUILDINGS IN A TIMELY MANNER. MANY OF THE BUILDINGS HAD SEVERAL ELECTRICAL PANELS AND PERSONNEL WERE NOT SURE OF WHICH BREAKER TO OPEN.

RECOMMENDATION: REVISE THE BUILDING EMERGENCY PLAN TO LIST SPECIFIC ELECTRICAL BOX PANEL/BREAKER ID NUMBERS FOR ELECTRICAL POWER DISCONNECTION DURING EMERGENCY CONDITIONS.

RESOLUTION:

SIGNATURES:

TEAM MEMBER:

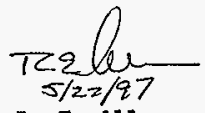

R. E. Allen

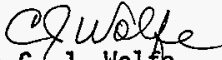

TEAM LEADER: C. J. Hol fe 


\section{ORR OBSERVATION FORM}

OBSERVATION NUMBER: $0.8-1.4 .2$

CORE REQUIREMENT NUMBER: 8-1 ADEQUATE EMERGENCY PREPAREDNESS ORGANIZATION AND PROGRAM.

CRITERIA NUMBER: $8-1.4$

CRITERIA STATEMENT: FACILITIES, EQUIPMENT, AND RESOURCES ARE IN PLACE AND ADEQUATE TO SUPPORT EMERGENCY RESPONSE OPERATIONS AND ENSURE THE PROTECTION OF ALL PERSONNEL (e.g., EMERGENCY OPERATIONS CENTER, BACKUP OR ALTERNATIVE FACILITIES, PRIMARY AND BACKUP COMMUNICATION, ALARM ADEQUATE TO NOTIFY PERSONNEL, TRANSPORTATION, MEDICAL TREATMENT, RESPIRATORY EQUIPMENT, EXPOSURE CONTROLS, INSTRUMENTATION TO MEASURE EXPOSURE, ETC.

DATE: $5 / 20 / 97$

OBSERVATION STATEMENT: SITE EVACUATION SIRENS ARE NOT DISCUSSED IN THE BUILDING EMERGENCY PLAN.

DISCUSSION/CONCLUSION: PERSONNEL HAVE BEEN TRAINED TO EVACUATE/TAKE COVER DURING SIREN SOUNDINGS PER HGET TRAINING. AN AWARENESS THAT SITE EMERGENCY SIRENS ARE LOCATED NEAR THE FACILITY SHOULD BE STATED IN THE BUILDING EMERGENCY PLAN.

RECOMMENDATION: AWARENESS OF OUTER PERIMETER EVACUATION/TAKE COVER SIRENS SHOULD BE PLACED IN THE BUILDING EMERGENCY PLAN.

RESOLUTION:

SIGNATURES :

TEAM MEMBER:

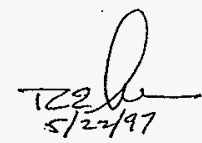

R. E. Allen

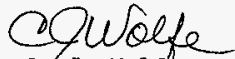

TEAM LEADER: C. J. WOIf fe 


\section{ORR OBȘĘRVATION FORM}

OBSERVATION NUMBER: $0.8-3.1 .1$

CORE REQUIREMENT NUMBER: 8.3 CORE REQUIREHENT STATEMENT: There is an adequate Environmental Protection organization and program.

CRITERIA NUMBER: $8.3 .1 \mathrm{c}$ CRITERIA STATEMENT: Is a Groundwater Monitoring protocol in place, to monitor possible contamination release from Phase $V$ or from trenches which may provide wastes to be received by Phase V?

DATE: May 20, 1997

\section{OBSERVATION STATEMENT:}

There is no current program in place which can monitor only possible contamination release from either Phase $V$ buildings, or the trenches which may supply wastes to Phase $V$.

DISCUSSION/CONCLUSION: This condition is a requirement in the current S/RID, section 20.3 and WAC 173-303-645. Discussion with CWC EC staff revealed that the current CWC philosophy continues a pre-PHMC approach, letting PNNL provide groundwater monitoring. Therefore, this is an issue needing correction in the S/RIDs.

Should CWC/SWD so decide, there are numerous RCRA-compliant monitoring wells in the 200-West Area, which are used to show that the entire 200-West Area meets requirements similar to this one. Results from these and other wells outside the 200-West boundary fence are collected for the annual Hanford Environmental Report (PNNL-11139, issued Sept 1996, for calendar year 1995).

The groundwater flow pattern is presented in the annual report; has been calculated beneath the 200-West Area for other programs; and the data should be available to comply with this requirement should it be determined.

RECOMMENDATION: The SWD/CWC management needs to review and update the S/RID document. It should determine what roles/responsibilities/requirements will be followed, consistent with the current PHMC contract, and memoranda of understanding with other primary site contractors.

A determination of significance needs to be made whether this requirement for CWC can be folded into the reporting for the entire 200-West Area possible releases. Concurrence with State regulators should also be sought for the final decision.

\section{RESOLUTION:}

SIGNATURES:

TEAM MEMBER:

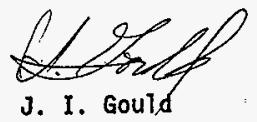

$5 \cdot 22-97$ 


\section{ORR OBSERVATION FORM}

OBSERVATION NUMBER: $0.8-3.2 .1$

CORE REQUIREMENT NUMBER: 8.3

adequate Environmental Protection organization and program.

CRITERIA NUMBER: $8.3 .2 \mathrm{a}$

CRITERIA STATEMENT: Has the Phase V

facility input waste stream been evaluated for potential-to-emit purposes, and is the facility going to be registered as a Toxic Air Pollutant (TAPs) source, per HAC 174-400-110 and 173-400-030.

DATE: May 20, 1997

\section{OBSERVATION STATEMENT:}

The Phase $V$ input waste streams can not be fully characterized in total; many container records are only category types and not quantifjed. A separate evaluation -- would be needed to determine if buildings 2404-WA,-WB, -WC contain sufficient source materials to require registration of the any Phase $V$ building as a whole.

DISCUSSION/CONCLUSION: Toxic Air Pollutant registration, if necessary, should be undertaken for only one building at a time. A systematic review of the container inventory on the SWITS database should be made, and a potential to emit for the same worst-case container breach accident used to determine a reasonable administrative control level for the number of vented drums, from each potential generator. As long as this inventory control is not exceeded, there would be no need for TAPs registration.

RECOMMENDATION: The SWD/CWC management needs to complete the evaluation of Phase $V$ conditions affecting possible TAPs registration. If TAPs registration is necessary, then a strategy should be developed which would require registration of the minimum number of buildings, consistent with the current operational policy of the CWC for Phase $V$.

No wastes in vented containers should be accepted into the Phase $V$ buildings, until this evaluation is completed. This is an action item from the Pre-ORR facility management review. Actionee is Kent McDonald, manager Environmental Compliance and Training.

RESOLUTION:

SIGNATURES:

TEAM MEMBER: J. I. GouTd

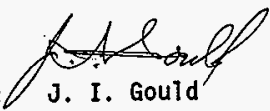

$5-22-97$
TEAM LEADER: c. J. Wolfo 


\section{ORR OBSERVATION FORM}

OBSERVATION NUMBER: $0.8-3.2 .2$

CORE REQUIREMENT NUMBER: 8.3

CORE REQUIREMENT STATEMENT: There is an adequate Environmental Protection organization and program.

CRITERIA NUMBER: $8.3 . \mathrm{b}$

CRITERIA STATEMENT: Is a complete 1 ist of the expected input waste streams (including designations) posted in the Phase $V$ facility for reference by facility workers and external oversight personnel? Is documentation incorporated in the Phase $V$ portion of the SAD Interim Safety Basis document? This is a requirement from the S/RID, section 20.2 .

DATE: May 20, 1997

\section{OBSERVATION STATEMENT:}

The Phase $V$ input waste streams can not be fully characterized. SWD scope of responsibility under the PHMC contract is to accept all wastes generated on site, provided that each container meets the published Hanford Waste Acceptance Criteria EP-0053-4 (soon to be rev 5). Also, the CWC is directed to accept wastes generated at selected other DOE facilities, provided that they meet the 0063 acceptance criteria.

DISCUSSION/CONCLUSION: The Phase $V$ buildings have been designed, evaluated, and registered for operation under the assumptions of the upgraded ISB. The inability to predict all potential input waste streams is not a function of the operational limits of either the ISB or the acceptance criteria 10063 document). Rather, this is an issue of comparability between the S/RIDs, and current scope of proposed operation.

RECOMMENDATION: The CWC/SWD management needs to include this criterion in consideration of the applicability of individual S/RIDs requirements for the Phase $V$ and other storage buildings. This observation can be closed simultaneously with observation 0.8.3.1.1, following the review/evaluation and revision of the S/RIDs for applicability.

Collection of the requirements for facility waste operations in a single referable document, represents a best management practice, with opportunity for process improvements. This issue is related to Phase $V$ conduct of operations.

RESOLUTION:

SIGNATURES: TEAM LEADER: $\mathrm{c}$ J. Wol te

$$
5 \cdot 22 \cdot 97
$$




\section{ORR OBȘĘRVATION FORM}

OBSERVATION NUMBER: $0.8-3.4 .1$

CORE REQUIREMENT NUMBER: 8.3

CORE REQUIREMENT STATEMENT: There is an adequate Environmental Protection organization and program.

CRITERIA NUMBER: $8.3 .4 \mathrm{a}$

CRITERIA STATEMENT: Is a Pollution

Prevention/Waste Minimization plan (goals, procedures, training, schedules, etc) being effectively implemented for the Phase V? Does the PP/W-M plan have a written policy showing local and corporate management support for implementation? Will wastes be treated or otherwise stabilized to reduce toxicity, availability to environment, reduce facility worker dose, etc) during storage? This is a requirement from the S/RID, section 20.5.

DATE: May 20, 1997

OBSERVATION STATEMENT: The CWC does not have a separate PP/W-M plan for Phase $\checkmark$ operation. The CWC management has chosen to operate under the Hanford SiteWide PP/W-M program. Phase $V$ will not perform any stabilization of container wastes to reduce toxicjty, availability to the environment, or reduction of potential facility worker exposure/dose.

DISCUSSION/CONCLUSION: The S/RIDs do not state whether individual facilities such as CWC/Phase $V$ should be required to implement a separate PP/W-M program. All similar actions are performed by either the generator of the container, by the WRAP facility or by SWD Generator services.

In the view of this ORR member, SWD or its parent organization RFSH/WMX, needs its own PP/W-M program. Operation under the present Hanford Site-wide PP/W-M program is not good business practice, due to divisions of responsibility which are in effect under the PHMC contract. CHC staff can improve the cultural climate for awareness of environmental impacts through the use of PP/W-M techniques and setting of appropriate goals. This will be useful when Phase $V$ begins to accept containers directly retrieved from burial trenches.

RECOMMENDATION: The CWC/SAD management needs to include this criterion for consideration of applicability of individual S/RIDs requirements for the Phase $V$ and other storage buildings. This observation can be closed simultaneously with observation 0.8 .3 .1 .1 , following the evaluation of the S/RIDs for applicability.

RESOLUTION:

SIGNATURES : TEAM MENBER:

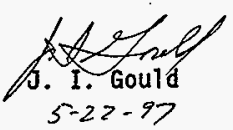

TEAH LEADER:

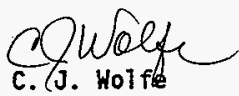

$$
5-27-97
$$




\section{ORR OBSERVATION FORM}

OBSERVATION NUMBER: $0.8-3 \cdot 10.1$

CORE REQUIREMENT NUMBER: 8.3

CORE REQUIREMENT STATEMENT: There is an adequate Environmental Protection organization and program.

CRITERIA NUMBER: $8.3 .10 \mathrm{f}$

CRITERIA STATEMENT: Are procedures in place to provide the following information in required (annual) reports: Emissions inventory, monitoring, investigation by oversight groups, demonstration/testing for regulatory compliance, air flow rate(s), emission logs, shutdown notifications, decontamination/decommissioning/closure, etc?

DATE: May 20, 1997

\section{OBSERVATION STATEMENT:}

The CWC EC maintains an extensive regulatory issues file, as required by CM-75 for all facilities on site. Data retrieval was judged satisfactory for environmental issues.

A second issue, the recording criteria for generating records was pursued; this path was less satisfactory. Instructions to record data are on most of the Plant Operating Procedures for a specific job task. Those PoPs actually examined stated (in many cases) that the data sheet was to be given to the first 7 ine supervisor or cog manager. This person was assumed to forward those records of environmental compliance nature to the CWC EC manager.

The Writers Guide for POPs was examined, under the headings of data sheets and records; it did not have a similar instruction to incorporate the forwarding to the CWC EC manager. This is an editorial deficiency, which has been operationally closed in the past by the general expertise of the Procedure writers, without the specific guidance.

DISCUSSION/CONCLUSION: This criterion addresses the general adequacy of the records management system, from the environmental perspective. The Facility Evaluation Board report, which was part of the background reading for the ORR Team, implied that the CWC EC organization was weak in its personnel support, covering deficiencies in other areas of application.

This ORR member investigated the possible impact of the FEB conclusions, and found that the CWC EC organization is suitably staffed, and in the case of multiple emergencies, or other schedule conflicts is able to call for temporary assistance from several other environmental organizations.

Adequacy of records retrieval was demonstrated. Several items were requested from different sources, and a road map was given to this ORR member with which to find the requested information; several of which were physically located.

CWC EC can $\mathrm{Call}^{-}$upon other environmental support organizations at T-Plant, 222-S Laboratory and the centra]. Environmental Services organization at 2440 Stevens. 
This criterion is similar to I-P Criterion 8.3.5: "Is a procedure in place to maintain a $l o g$ of inspections for compliance of Phase $V$ stored wastes. Are sufficient numbers of environmental personnel available to support these inspections?"

The Writers Guide for POPS was examined, under several headings of data sheets and records; it did not have a similar instruction to incorporate the forwarding to the CWC EC manager. This is an editorial deficiency, which apparently has been operationally closed in the past by the general expertise of the Procedure writers, without the specific guidance.

RECOMMENDATION: The CWC EC management has been very pro-active in developing cross-training for backup within its own staff, and interfaces with the other SWD facilities and the central ES organizations. It participates in regular Environmentai Compliance officer meetings, as well as one-on-one consulting to define issues and develop strategy. This is a good business practice, and is a positive note for the CWC EC organization, and should be continued.

The Writers' Guide for POPs should be reviewed and revised to clatrify further disposition of records generated by individual POPs, as appropriate.

\section{RESOLUTION:}

SIGNATURES: TEAM MEMBER:

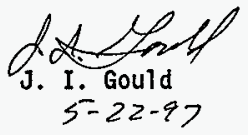

TEAM LEADER: C. J. WoIfle

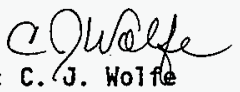




\section{ORR OBSER்}

OBSERVATION NUMBER: $0.8 \cdot 3.14 .1$

CORE REQUIREHENT NUHBER: 8.3

CORE REQUIREMENT STATEMENT: There is an adequate Environmental Protection organization and program.

CRITERIA NUMBER: 8.3 .14

CRITERIA STATEMENT: Personnel in the

environmental compliance organization have the needed knowledge, skills, and abilities to conduct the program.

DATE: May 20, 1997

\section{OBSERVATION STATEMENT:}

The CWC Environmental Compliance organization is very aggressive in doing facility inspections, and maintains a $\log$ of the results in the organization office in $\mathrm{MO}-720$.

When the workload of the normally assigned staff is excessive, CWC EC can call upon other environmental support organizations at T-Plant, 222-S Laboratory and the central Environmenta? Services organization at 2440 Stevens to assist in the inspections.

DISCUSSION/CONCLUSION: The Facility Evaluation Board report, which was supplied as part of the background reading for the ORR Team, implied that the CWC EC organization was weak in its personnel support, covering deficiencies in other areas of application. This ORR member investigated the possible impact of the FEB conclusions, and found that the CWC EC organization is suitably staffed, and in the case of multiple emergencies, or other schedule conflicts is able to call for temporary support from several other environmental organization, as noted.

This criterion is similar to Criterion 5, which requires: Is a procedure in place to maintain a log of inspections for compliance of Phase $V$ stored wastes. Are sufficient numbers of environmental personnel available to support these inspections?

RECOMMENDATION: The CWC EC management has been very pro-active in developing cross-training for backup within its own staff, and interfaces with the other SWD facilities and the central ES organizations. It participates in regular Environmental Compliance officer meetings, as well as one-on-one consulting to define issues and develop strategy. This is a good business practice, and is a positive note for the CWC EC organization.

RESOLUTION:

SIGNATURES: TEAM MEHBER:

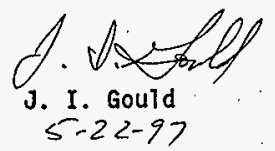

TEAM LEADER:

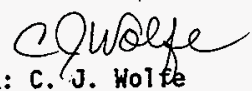




\section{ORR OBSERVATION FORM}

OBSERVATION NUMBER: $0.8-10.7 .1$

CORE REQUIREMENT NUMBER: $8-10$

CORE REQUIREMENT STATEMENT: There exists an adequate configuration management program to assure necessary change and drawing control of plant structures, systems, and components and to assure changes are reflected in training, procedure development, maintenance instructions, and technical baseline.

CRITERIA NUMBER: 7

CRITERIA STATEMENT:An administrative program is in place to ensure that modifications are analyzed, documented, approved by appropriate personnel and organizations, and reflected in design drawings, new/revised procedures and training materials.

DATE: $05 / 15 / 97$

OBSERVATION STATEMENT: Noted the configuration control and change process for Plant Operations Procedures as a 'Good Practice'. All current Plant Operations Procedures (POPS) and all associated illustrations and figures are available electronically on a shared drive. Changes to POPs are initiated and authorized using a Document Change Request (DCR) form. Draft procedure changes are routed for review and approval using a Document Acceptance Review Form (DARF). Procedures with changes in-process are all indexed on a master status tracking list. This status 1 ist is available (read only) to all employees electronically and includes the responsible individual currentiy assigned a review/comment action. Once a POP revision has been approved, the electronic version of the new/revised procedure is made available on the shared drive. A hard copy listing of all current controlled POPs is printed daily for quick procedure control reference (this list is also available on the shared drive). An entire hard copy set of all the current POPs is maintained for use in the event that the network is down. A revision history of procedure changes, including the entire electronic versions of all previous procedure revisions, is available for the past two (2) years.

DISCUSSION/CONCLUSION:

RECOMMENDATION:

RESOLUTION:

SIGNATURES:

TEAM MEMBER:

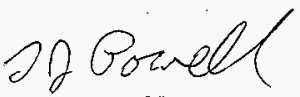

T. J. Powell

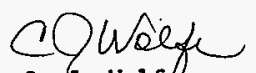

TEAM LEADER:
: 3. Wolfe 


\section{ORR OBSERVATION FORM}

OBSERVATION NUMBER: $0.8-11.1 .1$

CORE REQUTREMENT NUMBER:8.11

CORE REQUIREMENT STATEMENT: An adequate records management/document program exists to assure that all important documents, records, and related information are maintained current and readily retrievable.

CRITERIA NUMBER: 1

CRITERIA STATEMENT: The records management program defines responsibilities for determining what documents will be controlled in a system; methods used for acquisition, identification, storage, retention, and retrieval of documents; and controls to be exercised for changes, distribution, and removal.

DATE: May 20, 1997

OBSERVATION STATEMENT: A unique records management program for Solid Waste Management that addresses all responsibilities, document controls, storage, and retrievability does not exist.

DISCUSSION/CONCLUSION: The review conducted for this core requirement was to assure that documentation associated with both project $W 112$ and implementation of the CWC Interim Safety Basis was being properiy controlied, retained, and retrieved. It was very difficult to review a non-existent program, although the records for maintenance, operations, and engineering were each being addressed independently from the others and appeared to be adequate.

RECOMMENDATION: Facility management needs to determine if the current records management processes are appropriate for a nuclear facility organization with hazard category 2 responsibilities. It is suggested that a management self assessment be conducted that looks at Records/Document Management from the top down which would result in a measure of confidence that the current processes meet all requirements and customer needs.

\section{RESOLUTION:}

SIGNATURES:

TEAM MEMBER: William $W$ Bowen

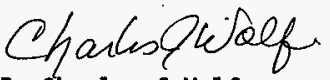

TEAN LEADER: Charles $\mathrm{J}$ Wolfe

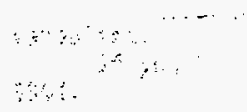




\section{ORR OBSERVATION FORM}

OBSERVATION NUMBER: 0.12 .1 .1

CORE REQUIREMENT NUMBER: 12 CORE REQUIREMENT STATEMENT: The impiementation status for DOE Order 5480.19, Conduct of Operations Requirements for DOE Facilities, is adequate for operations

CRITERIA NUMBER: 1

CRITERIA STATEMENT: The facility has implemented the WHC-CM-5-34 Conduct of Operations chapters.

DATE: MAY 21, 1997

OBSERVATION STATEMENT: The following deficiencies were noted during reviewS of documentation and field observations of work in progress:

1) CWC Operators are reporting out of specification surveillance conditions to the Operations Team Leader. However, they are not red circling these readings as required by $5-34$, Section 3.7 , para. 4.6 .

2) Team Leaders are not Togging in the Facility Logbook periodic observations of operator rounds as required by 5-34, Section 3.7, para. 4.6 .

3) SW-040-043, Inspect the CWC and Sodium Storage Building, establishes an expectation that comminications be maintained with operations personne? in the complex. However, communications with these personnel is difficult because of shared radio channels, radios not working properly and operations personnel not maintaining beepers on or with adequate batteries. (Finding F.8.1.4.2 specifically addresses problems with radio communications.)

4) 5-34, Section 3.5, Rev 2, para. 2.0 cites SWD facilities as Hazard Category 3 vice Hazard Category 2 as indicated in the Interim Safety Bas is document.

5) Posted criticality prevention specifications in the storage buildings are not being controlled as operator aids. Operations personnel are relying on an individual's knowledge and quarterly inspections by compliance personnel to ensure the CPS postings are current.

6) Non-active alarms on the CAM alarm panel for the 2403 series buildings are not labeled as required by $5-34$, Section $3.16,5.0 .1$.

DISCUSSION/CONCLUSION: These deficiencies were found during comprehensive reviews of conduct of operations documentation and practices at the CWC facility and are not indicative of programatic failures for anyof athe areas. reviewed. 
RECOMMENDATION: Establish corrective actions for the above items on a not to delay startup of the Phase $V$ buildings basis.

RESOLUTION:

SIGNATURES:

TEAM MEMBER:
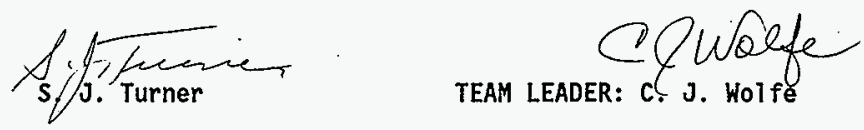


\section{APPENDIX C}

\section{LINES OF INQUIRY}


Core Requirement 1.0 There are adequate and correct procedures and safety limits for operating the process and utility systems.

\begin{tabular}{|c|c|c|c|c|}
\hline \multirow{2}{*}{$\begin{array}{c}\text { SUBJECT/ACTIVITY } \\
\text { REQUIREMENT REFERENCE }\end{array}$} & \multirow{2}{*}{$\begin{array}{l}\text { EVIDENCE EXAMINED/ } \\
\text { PERSONNEL CONTACTED }\end{array}$} & \multirow{2}{*}{ OBSERVATIONS/COMMENTS } & \multicolumn{2}{|c|}{ COMPLY } \\
\hline & & & YES & NO \\
\hline $\begin{array}{l}\text { References, } \mathrm{HHC}_{\mathrm{CH}-5-34}, 3.22 \\
\mathrm{ISB}-007, \mathrm{ReV} 0 \\
\mathrm{TSR}-0.05\end{array}$ & + & ४४४ - & & \\
\hline $\begin{array}{l}\text { 1. Have operating procedures } \\
\text { been updated to reflect ISB } \\
\text { requirements and the addition of } \\
2404 \text { buildings? }\end{array}$ & $\begin{array}{l}\text { SW-001-310, } 330 \\
S W-040-043,051 \\
\text { SW-100-110 } \\
\text { SW-150-003, } 005\end{array}$ & $\begin{array}{l}\text { Al1 procedures reviewed have been } \\
\text { updated to reflect ISB/IOSR } \\
\text { requirements, are considered } \\
\text { technically correct and include } \\
\text { the } 2404 \text { buildings. }\end{array}$ & $X$ & \\
\hline $\begin{array}{l}\text { 2. Do operating procedures } \\
\text { accurately incorporate IOSR } \\
\text { administrative controls? }\end{array}$ & $\begin{array}{l}\text { SW-001-310, } 330 \\
\text { SW-040-043, } 051 \\
\text { SW-100-110 } \\
\text { SW-150-003, } 005\end{array}$ & $\begin{array}{l}\text { All procedures reviewed have been } \\
\text { updated to reflect ISB/IOSR } \\
\text { requirements, are considered } \\
\text { technically correct and include } \\
\text { the } 2404 \text { buildings. }\end{array}$ & $X$ & \\
\hline $\begin{array}{l}\text { 3. Are technical details } \\
\text { correct and consistent between } \\
\text { operating procedures, drawings, } \\
\text { systems descriptions and } \\
\text { training? }\end{array}$ & $\begin{array}{l}S W-001-310,330 \\
S W-040-043,051 \\
S W-100-110 \\
S W-150-003,005\end{array}$ & $\begin{array}{l}\text { A11 procedures reviewed have been } \\
\text { updated to reflect ISB/IOSR } \\
\text { requirements, are considered } \\
\text { technically correct and include } \\
\text { the } 2404 \text { buildings. } \\
\text { Procedure SW-001-310 is missing } \\
\text { steps from the BEP, HNF-IP-0263- } \\
\text { CWC. (Details included in findings } \\
\text { and observations.) }\end{array}$ & & $x$ \\
\hline $\begin{array}{l}\text { 4. Is a program in place that } \\
\text { ensures periodic review and } \\
\text { update of procedures? }\end{array}$ & $\begin{array}{l}\text { Procedure change program } \\
\text { Jan Van Slyck }\end{array}$ & $\begin{array}{l}\text { The facility has all procedures on } \\
\text { the I drive with one set of } \\
\text { goldenrod procedures as backup. } \\
\text { The procedure administrator has a } \\
\text { number of internal control } \\
\text { mechanisms in place to ensure } \\
\text { procedures are updated and to } \\
\text { ensure comments on procedures are } \\
\text { dispositioned. DARFs are used for } \\
\text { review and approval. }\end{array}$ & $x$ & \\
\hline
\end{tabular}




\begin{tabular}{|c|c|c|c|c|}
\hline \multirow{2}{*}{$\begin{array}{l}\text { SUBJECT/ACTIVITY } \\
\text { REQUIREMENT REFERENCE }\end{array}$} & \multirow{2}{*}{$\begin{array}{l}\text { EVIDENCE EXAMINED/ } \\
\text { PERSONNEL CONTACTED }\end{array}$} & \multirow{2}{*}{ OBSERVATIONS/COMMENTS } & \multicolumn{2}{|c|}{ COMPLY } \\
\hline & & & YES & No \\
\hline $\begin{array}{l}\text { 5. Are temporary procedure } \\
\text { change controls specified and } \\
\text { being followed? }\end{array}$ & $\begin{array}{l}\text { No temporary procedure changes } \\
\text { were found. }\end{array}$ & Not Observed & & \\
\hline $\begin{array}{l}\text { 6. Is training provided to } \\
\text { operations personnel on } \\
\text { procedure changes prior to use? }\end{array}$ & $\begin{array}{l}\text { Required reading } \\
\text { Attended a training session } \\
\text { provided by R. Ames for the ISB } \\
\text { Reviewed ISB training records }\end{array}$ & $\begin{array}{l}\text { Required reading is the principat } \\
\text { tool used for procedure changes } \\
\text { and is routed to operations } \\
\text { personnel for review and } \\
\text { signature. } \\
\text { ISB implementation training was } \\
\text { provided and documented for } \\
\text { operations personne1. Training } \\
\text { provided for the review team on } \\
5 / 14 / 97 \text { covered the key elements } \\
\text { in the IOSRs. }\end{array}$ & $x$ & \\
\hline $\begin{array}{l}\text { 7. Is training on procedure } \\
\text { changes documented? }\end{array}$ & Required reading & $\begin{array}{l}\text { Procedure changes are routed } \\
\text { through operations personnel for } \\
\text { review and signature. The } \\
\text { Operations Secretary and CWC Team } \\
\text { Leader progress required reading. } \\
\text { As noted above, special training } \\
\text { was provided for ISB } \\
\text { implementation. }\end{array}$ & $x$ & \\
\hline $\begin{array}{l}\text { 8. Are personnel complying with } \\
\text { procedures in the field? }\end{array}$ & $\begin{array}{l}\text { Observed work using the } \\
\text { following procedures: SW-001- } \\
310 \text {, SW-040-043, and SW-100-110 }\end{array}$ & $\begin{array}{l}\text { Procedures were not used during an } \\
\text { observed drill and some steps were } \\
\text { missed. Found some instances of } \\
\text { inattention to detail in following } \\
\text { procedures. Some fire system } \\
\text { components were found to be } \\
\text { missing labels in } 2404 \text { series } \\
\text { buildings. (Details are included } \\
\text { in findings and observations.) }\end{array}$ & & $x$ \\
\hline
\end{tabular}




\section{PHASE V STORAGE ORR APPRAISAL FORM}

Training 2.1

CORE REQUIREMENT: Training and qualification programs for operations and operations support personnel have been established, documented, and implemented (the training and qualification programs encompass the range of duties and activities required to be performed).

APPROACH: Review training goals, procedures, and records. Interview training personnel. Observe, if possible, trained personne? performance.

CRITERIA: Training and qualification programs for operations and operations support personnel have been established, documented, and implemented.

1. Procedures are developed and implemented that describe the qualification process.

2. Procedures include examination requirements for certification of operations and maintenance personnel, requalification, maintenance of proficiency, granting of exceptions and extensions, alternatives to educational requirements, remediation, and evaluations by facility and training management.

3. Goals, objectives, and plans are in place to describe the implementation of the training and qualification programs.

4. Classroom training is conducted in accordance with formal lesson plans based to established learning objectives.

5. Written and oral examinations are used to evaluate trainee comprehension of training content.

6. Training programs incorporate formal on-the-job training (0JT) and hands-on evaluation of skills.

7. The qualification program includes requirements for successful completion of written, oral, operations evaluations for operations and maintenance personnel.

8. Procedures are in place to ensure that non-resident personnel have received the proper training for escorted and unescorted access to the CWC and are current in their training requirements.

\begin{tabular}{|c|c|c|c|c|}
\hline \multirow{2}{*}{$\begin{array}{c}\text { SUBJECT/ACTIVITY } \\
\text { REQUIREMENT REFERENCE }\end{array}$} & \multirow{2}{*}{$\begin{array}{l}\text { EVIDENCE EXAMINED/ } \\
\text { PERSONNEL CONTACTED }\end{array}$} & \multirow[t]{2}{*}{ OBSERVATIONS/COMMENTS } & \multicolumn{2}{|c|}{ ACCEPTABLE } \\
\hline & & & YES & No \\
\hline
\end{tabular}




\begin{tabular}{|c|c|c|c|}
\hline $\begin{array}{l}\text { 1) Review training and } \\
\text { qualification records for } \\
\text { operators, maintenance } \\
\text { personnel, shift technical } \\
\text { engineers, and supervisors, } \\
\text { including results of written, } \\
\text { oral, and operational } \\
\text { evaluations, to ensure the } \\
\text { training program is being } \\
\text { formally administered. }\end{array}$ & $\begin{array}{l}\text { Reviewed training records for } 4 \\
\text { Engineers and Lead Personnel and } \\
\text { training records for } 4 \text { NPOs. }\end{array}$ & Training program is being formally administered. & $x$ \\
\hline $\begin{array}{l}\text { 2) Verify training records } \\
\text { are maintained in an auditable } \\
\text { manner and support management } \\
\text { information needs by providing } \\
\text { required data on each } \\
\text { individual's training } \\
\text { participation, performance, } \\
\text { and qualification or } \\
\text { certification. }\end{array}$ & $" 1$ & $\begin{array}{l}\text { Training records are maintained neat and orderly, all } \\
\text { information is in the file, required information is } \\
\text { present. Records are easily auditable. }\end{array}$ & $x$ \\
\hline $\begin{array}{l}\text { 3) Review the evaluation and } \\
\text { self-assessment program for } \\
\text { involvement by facility and } \\
\text { training management in } \\
\text { program, instructor (classroom } \\
\text { and OJT), and training } \\
\text { materials assessment. }\end{array}$ & $\begin{array}{l}\text { CM-5-34, Section } 1.8, \text { para. } \\
5.4 .4 \text {, para. } 5.4 .5 \\
\text { Manager, Envi ronmental } \\
\text { Compl iance and Training }\end{array}$ & $\begin{array}{l}\text { There is a HATs item for training evaluation resulting from } \\
\text { the FEB evaluation. Item is due to complete by } 6 / 30 / 97 \text {. }\end{array}$ & $x$ \\
\hline $\begin{array}{l}\text { 4) Review the remedial } \\
\text { training program for adequacy. }\end{array}$ & $\begin{array}{l}\text { CM-5-34, Section } 1.8 \\
\text { Manager, Environmental } \\
\text { Compliance and Training. }\end{array}$ & $\begin{array}{l}\text { Procedure is adequate. } \\
\text { Program is implemented - self study focussed. }\end{array}$ & $x$ \\
\hline $\begin{array}{l}\text { 5) Review the CWC access } \\
\text { control procedures for } \\
\text { positive control of non- } \\
\text { resident personnel. }\end{array}$ & CM-5-34, Section 1.8 & $\begin{array}{l}\text { Access Control procedure is adequate and provides for } \\
\text { positive control of visitors. } \\
\text { (Field visit reveals that access is not positively } \\
\text { controlled. Although procedure is adequate, implementation } \\
\text { allows visitor to bypass the check- in point and to enter } \\
\text { facility unmonitored) }\end{array}$ & $x$ \\
\hline $\begin{array}{l}\text { 6) Review the written goals } \\
\text { and objectives related to the } \\
\text { implementation of the training } \\
\text { and qualification processes } \\
\text { and ensure they are documented } \\
\text { in strategic plans and that } \\
\text { the goals and objectives } \\
\text { adequately address the current } \\
\text { issues that are important to } \\
\text { both contractor management and } \\
\text { DoE. }\end{array}$ & $\begin{array}{l}\text { CM-5-34, Section } 1.8 \text {, Rev. } 4 \\
4 / 1 / 96 \\
\text { K. McDonald } \\
\text { J. Carlson }\end{array}$ & $\begin{array}{l}\text { Training plan is satisfactory and contains all elements for } \\
\text { a successful program. } \\
\text { FEB report noted weakness in documentation of training } \\
\text { package development. Program is in process to develop new } \\
\text { training packages to guidelines of DOE Order } 5480-.20 \mathrm{~A} \text {. } \\
\text { Due at end of FY1997. }\end{array}$ & $x$ \\
\hline
\end{tabular}




\begin{tabular}{|c|c|c|c|}
\hline $\begin{array}{l}\text { 7) Interview training } \\
\text { personnel to determine if they } \\
\text { have sufficient experience and } \\
\text { qual ifications for assessing } \\
\text { operations and maintenance } \\
\text { personnel. (Interview } \\
\text { questions directed } \\
\text { specifically to previous } \\
\text { experience and qualifications, } \\
\text { certifications, or training } \\
\text { for accompl ishing this } \\
\text { objective.) }\end{array}$ & $\begin{array}{l}\text { K. McDonald } \\
\text { J. Carlson } \\
\text { L. Olson } \\
\text { M. McLellan } \\
\text { C. Haas }\end{array}$ & $\begin{array}{l}\text { Experience and qualifications include appropriate training } \\
\text { instructor courses and certification, thorough plant } \\
\text { knowledge, holding advanced degree in an appropriate field, } \\
\text { Management experience, Naval Nuclear experience. }\end{array}$ & $x$ \\
\hline $\begin{array}{l}\text { 8) Observe operator, } \\
\text { operations support personnel, } \\
\text { or supervisor examinations, by } \\
\text { attending oral or operational } \\
\text { evaluations (OJr), if } \\
\text { possible. }\end{array}$ & $\mathrm{N} / \mathrm{A}$ & & \\
\hline $\begin{array}{l}\text { 9) Verify that personnel } \\
\text { demonstrate knowledge of } \\
\text { activities and evolutions that } \\
\text { were included in their } \\
\text { training program. }\end{array}$ & See Core Requirement \#3. & & \\
\hline & & & \\
\hline & & & \\
\hline
\end{tabular}


Training 2.2

CORE REQUIREMENT: Training and qualification programs for operations and operations support personnel have been established, documented, and implemented (the training and qualification programs encompass the range of duties and activities required to be performed).

APPROACH: Review training program content. Interview training personnel. Observe training in process.

CRITERIA: The training and qualification programs encompass the range of duties and activities required to be performed.

9. The tasks required for the personnel working in the CWC are identified and documented through a systematic analysis of job requirements.

10. The training program is based on the results of this analysis. Learning objectives are derived from the analysis.

11. Requirements for continuing training have been adequately defined and programs have been developed.

12. Continuing training includes conduct of realistic drills to maintain proficiency in responding to abnormal and accident situations, including those involving radiological and dangerous waste hazards.

13. Training programs for operations and maintenance personnel include training on the requirements contained in the approved operating basis for the facility.

14. Training programs for operations and maintenance personnel emphasize the importance of compliance with procedures and safety requirements.

15. Training for technical staff personnel is based on an assessment of position duties and responsibilities associated with operating the CWC.

16. The training department uses post-training feedback, internal evaluations (self assessment), and operating experience to modify the training program when needed. This inciudes:

$0 \quad$ Using feedback on training effectiveness from trainees and supervisors

o Incorporating feedback from operating experience at the site and from other DOE sites

- Conducting formal reviews of training effectiveness

o Incorporating comments from line management self-assessments and other audits. 


\begin{tabular}{|c|c|c|c|c|}
\hline \multirow{2}{*}{$\begin{array}{c}\text { SUBJECT/ACTIVITY } \\
\text { REQUIREMENT REFERENCE }\end{array}$} & \multirow{2}{*}{$\begin{array}{l}\text { EVIDENCE EXAMINED/ } \\
\text { PERSONNEL CONTACTED }\end{array}$} & \multirow[t]{2}{*}{ OBSERVATIONS/COMMENTS } & \multicolumn{2}{|c|}{ ACCEPTABLE } \\
\hline & & & YES & No \\
\hline $\begin{array}{l}\text { 1) Review operations and } \\
\text { maintenance lesson plans for } \\
\text { incorporation of safety } \\
\text { requirements; technical safety } \\
\text { requirements, operational } \\
\text { safety requi rements, and } \\
\text { procedure compliance. }\end{array}$ & $\begin{array}{l}\text { Lesson Plan Course W-112: } \\
\text { a. New Authorization Basis for } \\
\text { the Central Waste Complex. } \\
\text { b. Central Waste Complex W- } \\
112 \text { Project (2404W series } \\
\text { buildings) Orientation Update. }\end{array}$ & Meets requirements. & $x$ & \\
\hline $\begin{array}{l}\text { 2) Review trainee feedback } \\
\text { forms, training evaluations of } \\
\text { lessons learned from operating } \\
\text { experiences, and formal } \\
\text { training program reviews to } \\
\text { verify feedback is addressed } \\
\text { in a formal manner. }\end{array}$ & K. McDonald & $\begin{array}{l}\text { Feedback solicited; received by instructor. } \\
\text { Instructor reviews and assesses. } \\
\text { Iraining Manager reviews and decides whether change is } \\
\text { required or not. } \\
\text { Resolution to FEB comment will incorporate feedback } \\
\text { comments designated for inclusion and remaining } \\
\text { unincorporated. }\end{array}$ & $x$ & \\
\hline $\begin{array}{l}\text { 3) Review the continuing } \\
\text { training program plan and } \\
\text { drill schedule to verify its } \\
\text { adequacy to support safe } \\
\text { operations. }\end{array}$ & K. McDonald & $\begin{array}{l}\text { Continuing training consists primarily of required reading } \\
\text { program, monthly safety meeting topics, and personnel } \\
\text { briefing for significant technical issues. HAIS item from } \\
\text { FEB comment to upgrade the recertification program and } \\
\text { include formal continuing training aspect. } \\
\text { Drill training schedule meets minimum requirements. } \\
\text { (Demonstration off normal exercise was unsatisfactory, } \\
\text { indicating Drill training program is marginal.) }\end{array}$ & $x$ & \\
\hline $\begin{array}{l}\text { 4) Review the systematic } \\
\text { analysis of job requirements } \\
\text { conducted to provide } \\
\text { reasonable assurance that all } \\
\text { tasks essential to safe and } \\
\text { efficient operation of the CWC } \\
\text { are addressed by the training } \\
\text { program. }\end{array}$ & $\begin{array}{l}\text { K. MeDonald } \\
\text { J. Carlson }\end{array}$ & $\begin{array}{l}\text { A systematic approach is being performed for revising the } \\
\text { training materials. Resulting product will be based on } \\
\text { operating procedures and Authorization Basis requirements. } \\
\text { Process will meet } 5480.20 A \text { requirements. Some portions are } \\
\text { complete or nearly complete: Needs Analys is, Job Analysis, } \\
\text { Task/Training correspondence Chart, rask Analysis. } \\
\text { Revision and upgrade program is scheduled to complete by } \\
\text { the end of FY1997. }\end{array}$ & $x$ & \\
\hline $\begin{array}{l}\text { 5) Verify that subject matter } \\
\text { experts, line management, and } \\
\text { training staff developed and } \\
\text { maintain a valid cWC } \\
\text { pperations task list as the } \\
\text { basis for the training } \\
\text { program. }\end{array}$ & & See item 4.) & & \\
\hline $\begin{array}{l}\text { 6) Verify that the current } \\
\text { facility safety analysis } \\
\text { report, operating procedures, } \\
\text { technical and professional } \\
\text { references, and } \\
\text { facility/industry operating } \\
\text { experience are used to } \\
\text { identify training content and } \\
\text { information for use in } \\
\text { developing training materials. }\end{array}$ & & See item \#4) & & \\
\hline
\end{tabular}




\begin{tabular}{|c|c|c|c|c|}
\hline $\begin{array}{l}\text { 7) Review the degree to which } \\
\text { on-the-job training and hands- } \\
\text { on evaluations for operations } \\
\text { and maintenance personnel are } \\
\text { used to reinforce classroom } \\
\text { activities. }\end{array}$ & R. Robbins & $\begin{array}{l}\text { Lead OJT Evaluator described OJT and OJT evaluation } \\
\text { process. Nearly a one-on-one training process. Process } \\
\text { emphasizes application of classroom knowledge to job } \\
\text { performance. Remedial program reinforces weak knowledge. } \\
\text { Management led oral examinations complete the reinforcing. }\end{array}$ & $x$ & \\
\hline $\begin{array}{l}\text { 8) Interview training } \\
\text { personnel responsible for } \\
\text { training and drill scenario } \\
\text { development and } \\
\text { implementation. } \\
\text { Interview personnel } \\
\text { responsible for establishing } \\
\text { training needs for operations } \\
\text { and maintenance personnel. }\end{array}$ & M. McLellan & & & \\
\hline $\begin{array}{l}\text { How are the tasks } \\
\text { determined for which } \\
\text { training is provided? }\end{array}$ & & $\begin{array}{l}\text { Generate task list based on interviews and evaluation of } \\
\text { what people do -- a list of needs. }\end{array}$ & $x$ & \\
\hline $\begin{array}{l}\text { What is the source of } \\
\text { the learning } \\
\text { objectives for the } \\
\text { training? }\end{array}$ & & POPs and task list define the needs. & $x$ & \\
\hline $\begin{array}{l}\text { Describe the source of } \\
\text { the continuing } \\
\text { training requirements. }\end{array}$ & & $\begin{array}{l}\text { Radcon refresher } \\
\text { Safety meetings } \\
\text { Required reading }\end{array}$ & $\mathrm{x}$ & \\
\hline $\begin{array}{l}\text { Where does the safety } \\
\text { authorization basis } \\
\text { fit into the training? }\end{array}$ & & $\begin{array}{l}\text { Recent briefing on new ISB for operations and operations } \\
\text { support personnel. }\end{array}$ & $x$ & \\
\hline $\begin{array}{l}\text { Describe how is } \\
\text { procedure compl iance } \\
\text { emphasized in the } \\
\text { training? }\end{array}$ & & Strong emphasis. Continued through OJT and OJT evaluation. & $\mathrm{x}$ & \\
\hline $\begin{array}{l}\text { What methods are used } \\
\text { to improve the } \\
\text { training program? }\end{array}$ & & $\begin{array}{l}\text { Revising training program materials to meet DOE } 5480.20 \mathrm{~A} \\
\text { requirements. Emphasis, money, and personnel are adequate } \\
\text { to complete the job. }\end{array}$ & $x$ & \\
\hline $\begin{array}{l}\text { 9) Observe operator and } \\
\text { maintenance personnel response } \\
\text { to drills. }\end{array}$ & ORR Drill off-normal exercise & Unsatisfactory. See discussion elsewhere in this report. & & $x$ \\
\hline $\begin{array}{l}\text { 10) Evaluate a training } \\
\text { classroom lecture or field } \\
\text { training activity for } \\
\text { technical and administrative } \\
\text { adequacy. }\end{array}$ & $\begin{array}{l}\text { ISB upgrade briefing presented } \\
\text { to ORR tean. } \\
2404 W \text { Series modules briefing } \\
\text { presented to ORR team. }\end{array}$ & $\begin{array}{l}\text { ISB briefing was satisfactory. } \\
\text { Facility mod briefing was unsatisfactory. Team feedback } \\
\text { provided. Later tour patched the holes. }\end{array}$ & $x$ & \\
\hline
\end{tabular}


Core Requirement 3.0 Level of knowledge of operations and operations support personnel is adequate based on reviews of examinations, examination results and selected interviews of operating and operations support personnel.

\begin{tabular}{|c|c|c|c|c|}
\hline \multirow{2}{*}{$\begin{array}{l}\text { SUBJECT/ACTIVITY } \\
\text { REQUIREMENT REFERENCE }\end{array}$} & \multirow{2}{*}{$\begin{array}{l}\text { EVIDENCE EXAMINED/ } \\
\text { PERSONNEL CONTACTED }\end{array}$} & \multirow{2}{*}{ OBSERVATIONS/COMMENTS } & \multicolumn{2}{|c|}{ COMPLY } \\
\hline & & & YES & NO \\
\hline 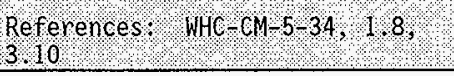 & & & & 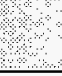 \\
\hline $\begin{array}{l}\text { 1. Does training provided to } \\
\text { operations and operations } \\
\text { support personnel reflect ISB } \\
\text { requirements and the addition of } \\
2404 \text { buildings? }\end{array}$ & $\begin{array}{l}\text { Reviewed training outline and } \\
\text { was provided the training in a } \\
\text { session on } 5 / 13 / 97 \text { by } R \text {. Ames }\end{array}$ & $\begin{array}{l}\text { The training included the } \\
\text { necessary elements of the ISB and } \\
\text { IOSRs. }\end{array}$ & $x$ & \\
\hline $\begin{array}{l}\text { 2. Does training include } \\
\text { written or oral examinations to } \\
\text { test personnel knowledge? }\end{array}$ & $\begin{array}{l}\text { Review of training } \\
\text { documentation }\end{array}$ & $\begin{array}{l}\text { No examinations were given on the } \\
\text { ISB and IOSR training. Facility } \\
\text { preparations included interviews } \\
\text { of operations, but not operations } \\
\text { support personnel. }\end{array}$ & & $x$ \\
\hline $\begin{array}{l}\text { 3. Is the examination material } \\
\text { of sufficient depth to } \\
\text { adequately test for an } \\
\text { understanding of applicable } \\
\text { facility/system capabilities, } \\
\text { limitations and requirements? }\end{array}$ & No exams given & Same as above & & $x$ \\
\hline $\begin{array}{l}\text { 4. Do examinations establish a } \\
\text { pass/fail criteria? }\end{array}$ & No exams given & Same as above & & $x$ \\
\hline $\begin{array}{l}\text { 5. Is the pass/fail criteria } \\
\text { adequate? }\end{array}$ & No exams given & Same as above & & $x$ \\
\hline
\end{tabular}




\begin{tabular}{|c|c|c|c|c|}
\hline \multirow{2}{*}{$\begin{array}{c}\text { SUBJECT /ACTIVITY } \\
\text { REQUIREMENT REFERENCE }\end{array}$} & \multirow{2}{*}{$\begin{array}{l}\text { EVIDENCE EXAMINED/ } \\
\text { PERSONNEL CONTACTED }\end{array}$} & \multirow{2}{*}{ OBSERVATIONS/COMMENTS } & \multicolumn{2}{|c|}{ COMPLY } \\
\hline & & & YES & No \\
\hline $\begin{array}{l}\text { 6. Do oral interviews of } \\
\text { operations and operations } \\
\text { support personnel indicate an } \\
\text { understanding of applicable } \\
\text { facility/system capabilities, } \\
\text { limitations and requirements? }\end{array}$ & $\begin{array}{l}\text { Discussions with operators and } \\
\text { CWC Team Leader on } 043 \text { and } 110 \\
\text { procedures. } \\
\text { Oral interviews conducted of } 5 \\
\text { operations support personnel } \\
\text { who had attended the ISB/IOSR } \\
\text { training. } \\
\text { B. Brannan } \\
\text { E. Millikin } \\
\text { R. Clinton } \\
\text { P. Hemsworth } \\
\text { G. Mickle }\end{array}$ & $\begin{array}{l}\text { Level of knowledge of operations } \\
\text { personnel was determined to be } \\
\text { satisfactory during procedure } \\
\text { discussions for core requirements } \\
1 \text { and } 12 \text {. } \\
5 \text { of } 5 \text { personnel interviewed did } \\
\text { not provide acceptable responses } \\
\text { to following questions: } \\
\text {-You attend the POD and are told } \\
\text { the facility is in restricted } \\
\text { mode. What does this mean? } \\
\text {-Please explain the adminjistrative } \\
\text { controls established by the I0SRs. } \\
\text { Partial answers were provided by } \\
\text { all personnel. }\end{array}$ & & $x$ \\
\hline
\end{tabular}




\section{Core Requirement 4}

Facility safety documentation is in place that describes the "safety envelope" of the facility. The safety documentation should characterize the hazards/risks associated with the facility and should identify mitigating measures (systems, procedures, administrative controls, etc.) that protect workers and the public from those hazards/risks. Safety systems and systems essential to worker and public safety are defined and a system to maintain control over the design and modification of facilities and safety-related utility systems is established.

\section{Approach:}

1. Ascertain that the authorization basis has been reviewed and approved by the proper organization based on the approval designator.

Verification of authorization basis was performed by reviewing the current ISB, HNF-SD-WM-ISB-007 and companion document HNF-SD-WM-TSR-005.

2. Review operating, maintenance, and administrative procedures to determine if the operation described is in within the limits of the authorization basis and proper controls are provided to maintain those limits.

Procedures were reviewed for content and application to ascertain compliance with the authorization basis envelope. Operating procedures reviewed were SW-100-110 Receive Radioactive Solid Waste At The Central Waste Complex and SW-100-043 Inspect The Central Waste Complex and Sodium Storage Building and Associated Equipment.

3. Review selected procedures to ascertain that the requirements of the authorization basis are noted as appropriate. Procedures called out in item 2 above were reviewed for authorization basis requirements.

4. Review documentation to ascertain that requirement for worker safety as it relates to industrial, hygiene, radiological, has been established. Worker safety is incorporated into the procedures mentioned in item 2 above and programmatically implemented through management.

5. Review the configuration control program to determine if changes include an evaluation for worker safety and authorization basis impact. The configuration control program as it relates to authorization basis is implemented through the WHC-CM-5-34 Solid Waste Disposal Operations Administration Manual Section 1.24 USQ Procedure.

6. Verify a program is in place that identifies workplace hazards and the information is used both in planning the work tasks and used by operating personnel in conducting work. Programs are in place to assure hazards are identified and addressed in the performance of work for the Central Waste Complex. These include the USQ procedure WHC-CM-5-34 Section 1.24 and Shift Routines and Operating Practices Section 3.7. Radiological issues are programmatically addressed in the HSRCM which 
implements 10 CFR 835. Industrial Safety and Industrial Hygiene are

\section{Criteria:}

1. The authorization basis for operation has been established, reviewed, and approved by WHC. The CWC ISB was approved by DOE in March of 1997 and fully implemented in April of 1997 .

2. Systems and support system to be operated within authorization basis. Based upon review of documentation in interviews with CWC personnel operations are conducted in compliance with the approved authorization basis.

3. Documentation provides for the protection of the worker and the public.

Documentation reviewed during the ORR reflects the concern and implementation of worker safety philosophy. A CPS clarity issue was identified as an observation.

4. Documentation is in accordance with applicable administrative and regulatory requirements for this type of facility. The documentation reflects the criteria for a Category 2 Nuclear Facility that performs non complex operations.

5. Program is in place to update the SAR/TSR and to evaluate impact of changes or errors to the authorization basis to the authorization basis.

WHC-CM-5-34 Section 1.24 USQ procedure implements the requirement for change control mandated by DOE 5480.21 .

6. A program is in place that identifies workplace hazards and the information is used in planning and conducting facility work. Several programs are implemented to identify hazards and address them in performance of work at the CWC. The Job Hazards Analysis is performed for tasks, maintenance, and work plans. The Radiation Work Permit addresses radiological hazards and the controls necessary to perform work in radiological environments. The ALARA review of work packages implements another tier of scrutiny to assure appropriate controls are addressed in the performance of work. The Joint Review Committee was developed to review hazards and concerns during high risk jobs or non-routine activities. The crafts are empowered with a safety logbook to identify hazards and bring them to the attention of management which is required to review and address the issues brought forth. The safety council is another forum by which safety issues are addressed.

\begin{tabular}{|c|c|c|c|c|}
\hline \multirow{2}{*}{$\begin{array}{c}\text { SUBJECT/ACTIVITY } \\
\text { REQUIREMENT REFERENCE }\end{array}$} & \multirow{2}{*}{$\begin{array}{l}\text { EVIDENCE EXAMINED/ } \\
\text { PERSONNEL CONTACTED }\end{array}$} & \multirow{2}{*}{ OBSERVATIONS/COMMENTS } & \multicolumn{2}{|c|}{ COMPLY } \\
\hline & & & YES & NO \\
\hline 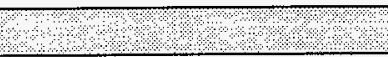 & ४ै। & अप & 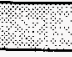 & \\
\hline 1.Criteria 1 & $\begin{array}{l}\text { HNF-SD-WM-ISB-007 } \\
\text { HNF-SD-WM-TSR-005 }\end{array}$ & $\begin{array}{l}\text { Document is approved by DOE and } \\
\text { the subcontractor. }\end{array}$ & YES & \\
\hline
\end{tabular}




\begin{tabular}{|c|c|c|c|c|}
\hline \multirow{2}{*}{$\begin{array}{c}\text { SUBJECT/ACTIVITY } \\
\text { REQUIREMENT REFERENCE }\end{array}$} & \multirow{2}{*}{$\begin{array}{l}\text { EVIDENCE EXAMINED/ } \\
\text { PERSONNEL CONTACTED }\end{array}$} & \multirow{2}{*}{ OBSERVAT IONS/COMMENTS } & \multicolumn{2}{|c|}{ COMPLY } \\
\hline & & & YES & No \\
\hline 2.Criteria 2 & $\begin{array}{l}\text { Interviews with CWC personnel: } \\
\text { Bob Girior Manager SWO-SWBG/CWC } \\
\text { Pau1 Crane Manager Operations } \\
\text { CWC } \\
\text { Mike Aichele CWC Team Lead } \\
\text { Rhonda Durfee Team Lead } \\
\text { Programs } \\
\text { Don Zahn CWC operator } \\
\text { Bruce Rogers CWC Lead Operator } \\
\text { Mat Irwin Manager Engineering } \\
\text { Randy Ames Team Lead CWC } \\
\text { Authorization Basis } \\
\text { Documents Reviewed: } \\
\text { HNF-SD-WM-ISB-007 } \\
\text { HNF-SD-WM-TSR-005 } \\
\text { PROCEDURE SW-100-043 } \\
\text { PROCEDURE SW-100-110 } \\
\text { HNF-CD-5-34 } 3.7 / 1.24 \\
\text { CPS-SW-149-00002 } \\
\text { FEB REPORT FDH- } 9752462\end{array}$ & $\begin{array}{l}\text { A weakness may exist within the } \\
\text { criticality prevention } \\
\text { specification relating to } \\
\text { mitigated accident scenarios. } \\
\text { SW-100-110 Section E, under } \\
\text { caution notes relating to } \\
\text { Flammable Acid segregation should } \\
\text { be changed to preclude } \\
\text { misinterpretation. Clarification } \\
\text { of inspection aisle widths and } \\
\text { segregation requirements according } \\
\text { to different drivers would be } \\
\text { helpful. (IE RCRA requirement or } \\
\text { ISB requirement etc) }\end{array}$ & YES & \\
\hline
\end{tabular}




\begin{tabular}{|c|c|c|c|c|}
\hline \multirow{2}{*}{$\begin{array}{l}\text { SUBJECT/ACTIVITY } \\
\text { REQUIREMENT REFERENCE }\end{array}$} & \multirow{2}{*}{$\begin{array}{l}\text { EVIDENCE EXAMINED/ } \\
\text { PERSONNEL CONTACTED }\end{array}$} & \multirow{2}{*}{ OBSERVATIONS/COMMENTS } & \multicolumn{2}{|c|}{ COMPLY } \\
\hline & & & YES & No \\
\hline 3.Criteria 3 & $\begin{array}{l}\text { Interviews with CWC personne } 1 \text { : } \\
\text { Bob Girior Manager SWO-SWBG/CWC } \\
\text { Paul Crane Manager Operations } \\
\text { CWC } \\
\text { Mike Aichele CWC Team Lead } \\
\text { Rhonda Durfee Team Lead } \\
\text { Programs } \\
\text { Don Zahn CWC operator } \\
\text { Bruce Rogers CWC Lead Operator } \\
\text { Mat Irwin Manager Engineering } \\
\text { Randy Ames Team Lead CWC } \\
\text { Authorization Basis } \\
\text { Documents Reviewed: } \\
\text { HNF-SD-WM-SB-007 } \\
\text { HNF-SD-WM-SSR-005 } \\
\text { PROCEDURE SW-100-043 } \\
\text { PROCEDURE SW-100-110 } \\
\text { HNF-CD-5-34 3.7/1.24 } \\
\text { CPS-SW-149-00002 } \\
\text { FEB REPORT FDH-9752462 } \\
\text { Management Self } \\
\text { AsSeSSment(W112) }\end{array}$ & $\begin{array}{l}\text { There is a high degree of } \\
\text { awareness related to hazards and } \\
\text { safety for the operation of the } \\
\text { facility. There was a clarity } \\
\text { issue identified as an } \\
\text { observation. Their CPS complies } \\
\text { with the intent of DOE } 5480.24 \text {, } \\
\text { however there appears to be an } \\
\text { area that was not clarified. As } \\
\text { part of the annual review of the } \\
\text { AB, it is suggested that critical } \\
\text { supporting documents be reviewed } \\
\text { for currency also. }\end{array}$ & YES & \\
\hline 4.criteria 4 & $\begin{array}{l}\text { Documents- Reviewed: } \\
\text { HNF-SD-WM-ISB-007 } \\
\text { HNF-SD-WM-TSR-005 } \\
\text { PROCEDURE SW-100-043 } \\
\text { PROCEDURE SW-100-110 } \\
\text { HNF-CD-5-34 } 3.7 / 1.24 \\
\text { CPS-SW-149-00002 } \\
\text { FEB REPORT FDH-9752462 } \\
\text { Management Self Assessment } \\
\text { (W112) }\end{array}$ & $\begin{array}{l}\text { Documentation is in place and } \\
\text { utilized by appropriate personnel. }\end{array}$ & YES & \\
\hline 5.Criteria 5 & $\begin{array}{l}\text { Document reviewed : } \\
\text { HNF-CM-5-34 Section } 1.24\end{array}$ & $\begin{array}{l}\text { The USQ process is implemented } \\
\text { through the mentioned section } \\
\text { reviewed. }\end{array}$ & YES & \\
\hline
\end{tabular}




\begin{tabular}{||c|l|l|c||}
\hline $\begin{array}{c}\text { SUBJECT/ACTIVITY } \\
\text { REQUIREMENT REFERENCE }\end{array}$ & \multicolumn{1}{|c|}{$\begin{array}{c}\text { EVIDENCE EXAMINED/ } \\
\text { PERSONNEL CONTACTED }\end{array}$} & OBSERVATIONS/COMMENTS & COMPLY \\
\hline \hline 6.Criteria 6 & $\begin{array}{l}\text { JHA, RWP, ALARA Review, Prejob, } \\
\text { Safety Meetings, JRC, Safety } \\
\text { Counci1 }\end{array}$ & $\begin{array}{l}\text { All mentioned processes contribute } \\
\text { to an awareness of safety, } \\
\text { hazards, and mitigation of } \\
\text { hazards. }\end{array}$ & YES \\
\hline
\end{tabular}




\section{Core Requirement 5:}

A program is in place to confirm and periodically reconfirm the condition and operability of safety systems, including safety-related process systems and safety-related utility systems. This includes examinations of records of tests and calibration of safety system and other instruments that monitor limiting conditions of operation or that satisfy

Technical Safety Requirements. All systems are currentiy operable and in a satisfactory condition. The items 1 isted below are specific prerequisites for this core requirement.

\section{CRITERIA:}

1. All safety systems and safety related process and utility systems are operable and available.

2. Operational Test Procedures have been completed and documented for all facility systems.

3. Review of completed surveillances and/or tests are conducted to ensure that acceptance criteria are met and any trends are identified.

\section{APPROACH:}

1. Review ATPS and OTPS to verify the adequacy of the administrative control program for test record retention and retrieval process, documentation for completion of testing and operational turnover. Verify that all tests were reviewed and approved by appropriate organization and departments.

2. Verify ATPS and OTPS have acceptance criteria defined, and the testing verified that they were met.

3. Review operability of: Critical systems; Compressed Air System; Fire Suppression System; Radiation Detection and Control Devices.

\begin{tabular}{|c|c|c|c|c|}
\hline \multirow{2}{*}{$\begin{array}{c}\text { SUBJECT/ACTIVITY } \\
\text { REQUIREMENT REFERENCE }\end{array}$} & \multirow{2}{*}{$\begin{array}{l}\text { EVIDENCE EXAMINED/ } \\
\text { PERSONNEL CONTACTED }\end{array}$} & \multirow{2}{*}{ OBSERVATIONS/COMMENTS } & \multicolumn{2}{|c|}{ COMPLY } \\
\hline & & & YES & No \\
\hline $\begin{array}{l}\text { 1. Did the test program confirm } \\
\text { al1 equipment met specified } \\
\text { acceptance criteria? (Electrical } \\
\text { power, compressed air, fire } \\
\text { suppression and radiation } \\
\text { detection) }\end{array}$ & $\begin{array}{l}\text { WHC-SD-W112-ATP-003, 004, } 005 \text {, } \\
006,007 \\
\text { Matt Irwin confirmed vender } \\
\text { Acceptance Test Report for } \\
\text { equipment met ATP criteria }\end{array}$ & & $x x$ & \\
\hline
\end{tabular}




\begin{tabular}{|c|c|c|c|c|}
\hline \multirow{2}{*}{$\begin{array}{c}\text { SUBJECT/ACTIVITY } \\
\text { REQUIREMENT REFERENCE }\end{array}$} & \multirow{2}{*}{$\begin{array}{l}\text { EVIDENCE EXAMINED/ } \\
\text { PERSONNEL CONTACTED }\end{array}$} & \multirow{2}{*}{ OBSERVATIONS/COMMENTS } & \multicolumn{2}{|c|}{ COMPLY } \\
\hline & & & YES & No \\
\hline $\begin{array}{l}\text { 2. Have test program procedures } \\
\text { been validated? }\end{array}$ & $\begin{array}{l}\text { Procedures were reviewed and } \\
\text { validated by KEH and WHC - } \\
\text { Matt Irwin }\end{array}$ & & $x x$ & \\
\hline $\begin{array}{l}\text { 3. Has on-the-job training been } \\
\text { conducted and documented } \\
\text { during/subsequent to the test } \\
\text { program? }\end{array}$ & $\begin{array}{l}\text { Buildings and systems in } W-112 \\
\text { are turn-key delivery. Systems } \\
\text { are run to failure. } \\
\text { Classroom training and an } \\
\text { orientation walkdown of the new } \\
\text { facilities provided. Operation } \\
\text { is consistent with existing } \\
\text { facilities at CWC. } \\
\text { Larry 0lsen, Training. }\end{array}$ & & $x x$ & \\
\hline $\begin{array}{l}\text { 4. Are specific controls } \\
\text { established for quality- } \\
\text { affecting software identified in } \\
\text { controlled and documented plans? } \\
\text { CM-5-36 (4.2, 4.2) }\end{array}$ & $\begin{array}{l}\text { Controls for regulating SWITS } \\
\text { are in HNF-IP-1097 }\end{array}$ & & $x x$ & \\
\hline $\begin{array}{l}\text { 5. Have verification reviews of } \\
\text { software documentation been } \\
\text { performed by individuals who are } \\
\text { independent? } \\
\text { CM-5-36 }(4.2,4.2 .2 .1)\end{array}$ & Yes, included in HNF-IP-1097 & & $x x$ & \\
\hline $\begin{array}{l}\text { 6. Have all startup test } \\
\text { program deficiencies been } \\
\text { corrected or evaluated as no } \\
\text { impact on startup? (ORs, ECNs, } \\
\text { NCRs) }\end{array}$ & $\begin{array}{l}\text { No formal OTP perfarmed. } \\
\text { Operational tests completed and } \\
\text { documented during initial PM }\end{array}$ & & $x x$ & \\
\hline $\begin{array}{l}\text { 1. Has the project been } \\
\text { officially accepted by Solid } \\
\text { Waste? }\end{array}$ & $\begin{array}{l}\text { Yes, Transmittal letter and } \\
\text { documentation } \\
\text { RFSH-9750257 }\end{array}$ & & $x x$ & \\
\hline
\end{tabular}




\begin{tabular}{|c|c|c|c|c|}
\hline \multirow{2}{*}{$\begin{array}{l}\text { SUBJECT/ACTIVITY } \\
\text { REQUIREMENT REFERENCE }\end{array}$} & \multirow{2}{*}{$\begin{array}{l}\text { EVIDENCE EXAMINED/ } \\
\text { PERSONNEL CONTACTED }\end{array}$} & \multirow{2}{*}{ OBSERVATIONS/COMMENTS } & \multicolumn{2}{|c|}{ COMPLY } \\
\hline & & & YES & NO \\
\hline $\begin{array}{l}\text { 2. Have all open items been } \\
\text { resoived? }\end{array}$ & $\begin{array}{l}\text { Matt Irwin } \\
\text { Sagebrush mitigation and } \\
\text { contractor claims remain open. } \\
\text { A11 building or systems item } \\
\text { are resolved. }\end{array}$ & & & \\
\hline $\begin{array}{l}\text { 3. Have incomplete items been } \\
\text { evaluated and none impact } \\
\text { facility start-up? }\end{array}$ & $\begin{array}{l}\text { Open items are not facility or } \\
\text { systems related. }\end{array}$ & & $x x$ & \\
\hline $\begin{array}{l}\text { 4. Have construction drawings } \\
\text { been turned over to Solid Waste } \\
\text { and a controlled drawing file } \\
\text { established? }\end{array}$ & $\begin{array}{l}\text { Yes, As-built and Operating and } \\
\text { Maintenance information on } \\
\text { file. }\end{array}$ & & $x x$ & \\
\hline $\begin{array}{l}\text { 5. Are there systems in place } \\
\text { to maintain operational and } \\
\text { modification configuration } \\
\text { control of facility systems and } \\
\text { components? }\end{array}$ & $\begin{array}{l}\text { WHC-CM-5-34 procedure } 2.1 \text { and } \\
2.3 \\
\text { Document control in M0-535. }\end{array}$ & & $x x$ & \\
\hline & & & & \\
\hline
\end{tabular}




\section{PHASE V STORAGE ORR APPRAISAL FORM}

CORE REQUIREMENT 6 - A process has been established to identify, evaluate, and resolve deficiencies and recommendations made by oversight groups, official review teams, audit organizations, and the operating contractor.

APPROACH: 1) Review Corrective Action Plan for FEB assessment of CWC Dec. 1996.

2) Verify implementation of the CAP has effectively addressed and rectified nonconformances.

CRITERIA: A system for identifying, reviewing, cataloging, and resolving deficiencies and recommendations is adequately implemented. (5480.19, CH VI and VIII; 5700.6C, para 9.b(1)(c), 9.b.(3)(a)).

\begin{tabular}{|c|c|c|c|c|}
\hline \multirow{2}{*}{$\begin{array}{l}\text { SUBJECT/ACTIVITY } \\
\text { REQUIREMENT } \\
\text { REFERENCE }\end{array}$} & \multirow{2}{*}{$\begin{array}{l}\text { EVIDENCE EXAMONED/ } \\
\text { PERSONNEL CONTACTED }\end{array}$} & \multirow[t]{2}{*}{ OBSERVATIONS/COMMENTS } & \multicolumn{2}{|c|}{ COMPLY } \\
\hline & & & YES & No \\
\hline $\begin{array}{l}\text { 1) Core Rqmt. } 6 \\
\text { Verify implementation of the } \\
\text { CAP to date has effectively } \\
\text { addressed and rectified } \\
\text { nonconformances identified in } \\
\text { the FEB Assessment }\end{array}$ & $\begin{array}{l}\text { All corrective actions identified } \\
\text { in the Corrective Action Plan } \\
\text { were reviewed. Those items } \\
\text { related to the Phase V Storage } \\
\text { Facil. were discussed with the } \\
\text { indicated personnel. }\end{array}$ & $\begin{array}{l}\text { RFSH conducted a root cause analysis of the } 4 \text { core issues } \\
\text { to ensure that the CAP accurately and comprehensively } \\
\text { addressed the real issues. }\end{array}$ & $\mathbf{X}$ & \\
\hline $\begin{array}{l}\text { 2) FEB ASSESSMENT } \\
2.1 .2 \\
\text { Management/Self- Assessment }\end{array}$ & $\begin{array}{l}\text { Solid Waste Management } \\
\text { Admin. HNF-IP-0845 "Mgt. } \\
\text { Overview Program" Solid } \\
\text { Waste Disposal } \\
\text { Operations Admin. } \\
\text { WHC-CM-5-34 Self Assmt. } \\
\text { QA - Dave Vance } \\
\text { FM - Robert Giroir } \\
\text { OPS - Michael Aichele } \\
\text { OPS - Jim Mitchell } \\
\text { OPS - Paul Crane } \\
\text { FS - Nancie Daniel } \\
\text { ENG - Mat Irwin }\end{array}$ & $\begin{array}{l}\text { Assessments are being conducted However, The FEB } \\
\text { identified a weakness in the implementation of the } \\
\text { program. FDH has issued a draft Mgt. Assessment } \\
\text { Procedure for comment. RFSH actions are in progress to } \\
\text { revise and upgrade the assessment process and a draft } \\
\text { procedure has been written to replace the one in WHC- } \\
\text { CM-5-34 with a due date of } 9 / 30 / 97 \text {. Surveillances of } \\
\text { routine operations are not currently being performed by } \\
\text { OPS - Compliance - marginal - with improvements in } \\
\text { process. }\end{array}$ & $\mathbf{X}$ & \\
\hline $\begin{array}{l}\text { 3) FEB ASSESSMENT } \\
2.1 .3 \\
\text { Requirements Management }\end{array}$ & $\begin{array}{l}\text { S/RWDs } \\
\text { Memorandum RFSH-9750224 } \\
\text { Revise RFSH S/RIDS in } \\
\text { accordance with Hanford site } \\
\text { wide guidelines. } \\
\text { FM - Robert Giroir } \\
\text { FS - Nancie Daniel }\end{array}$ & $\begin{array}{l}\text { As previously committed to DOE-RL and FDH the update } \\
\text { of the RFSH S/RWDs is in progress with a forecast } \\
\text { completion date of } 7 / 18 / 97 \text {. This action is administrative. } \\
\text { There is an approved S/RID for the current ongoing } \\
\text { operations. The Phase V (Project W-112) addition will } \\
\text { not introduce new work processes. The current work } \\
\text { processes are being upgraded as indicated in the CAP. } \\
\text { There is no physical impact to operations resulting from } \\
\text { this corrective action. }\end{array}$ & N/A & \\
\hline
\end{tabular}




\begin{tabular}{|c|c|c|c|}
\hline $\begin{array}{l}\text { 4) FEB ASSESSMENT } \\
2.1 .4 \\
\text { GOALS }\end{array}$ & $\begin{array}{l}\text { CAP 2.1.4.1 Develop } \\
\text { performance indicators to } \\
\text { clearly communicate } \\
\text { performance goals and } \\
\text { objectives to Solid Waste } \\
\text { Operations empl. } \\
\text { FM - Robert Giroir } \\
\text { OPS - Paul Crane }\end{array}$ & Performance indicators have been developed and posted. & $\mathbf{x}$ \\
\hline $\begin{array}{l}\text { 5) FEB ASSESSMENT } \\
2.2 .1 \\
\text { Operating Practices }\end{array}$ & $\begin{array}{l}\text { CAP 2.2.1.1 Develop a } \\
\text { management High Risk Review } \\
\text { Committee (HRRC) to provide } \\
\text { additional management } \\
\text { oversight and review for the } \\
\text { performance of high risk } \\
\text { and/or non-routine activities. } \\
\text { FM - Robert Giroir } \\
\text { OPS - Paul Crane } \\
\text { FS - Nancie Daniel } \\
\text { RC - Brad Brannon } \\
\text { QA - Dave Vance } \\
\text { ENG - Mat Irwin }\end{array}$ & $\begin{array}{l}\text { A HRRC was established and then evolved into further } \\
\text { into a Joint Review Committee. The charter was } \\
\text { expanded from "just" High Risk activities to also include } \\
\text { infrequently performed work activities. All cognizant } \\
\text { management and technical disciplines participate } \\
\text { including QA, H\&S, Rad Con, II, and expertise from } \\
\text { outside the organization as required. JRC-97-02 Tank } \\
\text { Farms Tanker Grouting dated April 22, } 1997 \text { provides an } \\
\text { example of JRC actions taken. (See procedure WHC-CM- } \\
\text { 5-34-1.19) }\end{array}$ & $\mathbf{x}$ \\
\hline $\begin{array}{l}\text { 6) FEB ASSESSMENT } \\
2.2 .1 \\
\text { Operating Practices }\end{array}$ & $\begin{array}{l}\text { 2.2.1.1 Implement a program } \\
\text { requiring weekly management } \\
\text { surveillances. Scope to include } \\
\text { pre-job meeting, hazard ident. } \\
\text { \& procedural consistency. } \\
\text { FM - Robert Giroir } \\
\text { QA - Dave Vance } \\
\text { OPS - Paul Crane } \\
\text { OPS - Jim Mitchell } \\
\text { OPS - Mike Aichele } \\
\text { OS - Nancie Daniel } \\
\text { ENV - Kent McDonald }\end{array}$ & $\begin{array}{l}\text { Weekly surveillances are being performed. } \\
\text { Each manager is scheduled weekly. Pat Bowmaster has } \\
\text { schedules. While these surveillances were specifically } \\
\text { established to be "Management Assessments" the QA } \\
\text { representative and other support functions such as Health } \\
\text { and Safety could team on occasion to provide more in } \\
\text { depth coverage. This has not yet been done. }\end{array}$ & $\mathbf{X}$ \\
\hline
\end{tabular}




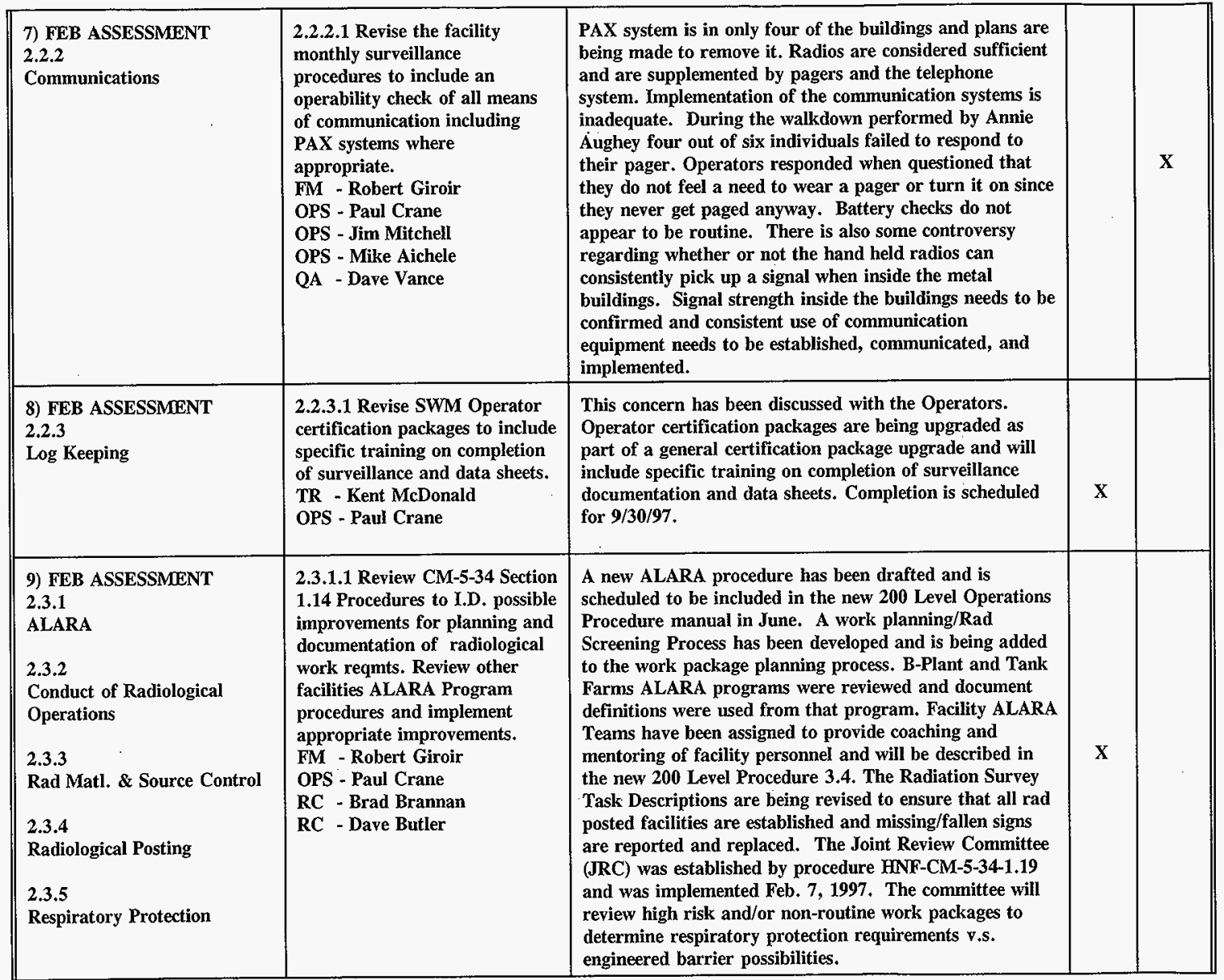




\begin{tabular}{|c|c|c|c|}
\hline $\begin{array}{l}\text { 10) FEB ASSESSMENT } \\
\text { 2.4.1 } \\
\text { Engineering Processes }\end{array}$ & $\begin{array}{l}\text { 2.4.1.2 Review USQ program } \\
\text { admin. record reqmt's in } \\
\text { Engineering and assign } \\
\text { responsibility to perform } \\
\text { verification of USQ records. } \\
\text { ENG - Mat Irwin } \\
\text { OPS - Paul Crane } \\
\text { OS - Nancie Daniel }\end{array}$ & $\begin{array}{l}\text { The review of the USQ program administrative record } \\
\text { requirements was followed by location of missing USQ } \\
\text { screening records which are now located in a fireproof file } \\
\text { cabinet. Karen Skelly now performs record verification } \\
\text { on a quarterly basis in parallel with the report to DOE on } \\
\text { USQs. }\end{array}$ & $\mathrm{X}$ \\
\hline $\begin{array}{l}\text { 11) FEB ASSESSMENT } \\
\text { 2.4.1 } \\
\text { Engineering Processes }\end{array}$ & $\begin{array}{l}\text { 2.4.1.4 Issue an approved } \\
\text { Maint. Imp. Plan(MIP) to } \\
\text { provide standard and sched. } \\
\text { for completing and maint. of } \\
\text { the Master Equip List. } \\
\text { ENG - Mat Irwin } \\
\text { OS - Nancie Daniel }\end{array}$ & $\begin{array}{l}\text { The Maint. \& Imp. Plan (MMP) has been updated and } \\
\text { includes labeling rqmts., drawings, \& Certified Vendor } \\
\text { Information. Robin Bushore has the assignment to } \\
\text { maintain the Master Equip. List current and up to date. } \\
\text { The documentation closing this corrective action is not yet } \\
\text { complete. }\end{array}$ & $\mathbf{x}$ \\
\hline $\begin{array}{l}\text { 12) FEB ASSESSMENT } \\
\text { 2.5.3 } \\
\text { Performance Monitoring and } \\
\text { Analysis }\end{array}$ & $\begin{array}{l}\text { 2.5.3.2 Develop program to } \\
\text { track and tend work sched. v.s. } \\
\text { the work completed. Status at } \\
\text { POD } \\
\text { OPS - Paul Crane } \\
\text { ENG - Mat Irwin } \\
\text { OS - Nancie Daniel }\end{array}$ & $\begin{array}{l}\text { A program has been developed where Level } 4 \text { s present } \\
\text { performance indicators such as ECN status, Safety \& } \\
\text { House Keeping Insp., Monthly Safety Mtgs., Facility } \\
\text { improvement proposals etc. at the Plan of the Day } \\
\text { Meetings. Documentation of the program is in progress. }\end{array}$ & $\mathbf{x}$ \\
\hline $\begin{array}{l}\text { 13) FEB ASSESSMENT } \\
2.5 .4 \\
\text { Quality of Work Control } \\
\text { Documentation }\end{array}$ & $\begin{array}{l}\text { 2.5.4.1 Revise internal work } \\
\text { mgt procedures to strengthen } \\
\text { rqmts for work package } \\
\text { documentation. } \\
\text { QA - Dave Vance } \\
\text { OPN - Paul Crane } \\
\text { ENG - Mat Irwin }\end{array}$ & $\begin{array}{l}\text { Internal work mgt. procedures are being revised with a } \\
\text { current schedule for completion of } 5 / 30 / 97 \text {. }\end{array}$ & $\mathbf{x}$ \\
\hline
\end{tabular}




\begin{tabular}{|c|c|c|c|}
\hline $\begin{array}{l}\text { 14) FEB ASSESSMENT } \\
\text { 2.6.1 } \\
\text { Occupational Safety Program } \\
\text { Implementation \& } \\
\text { Performance }\end{array}$ & $\begin{array}{l}\text { 2.6.1.1 Implement strengthened } \\
\text { interim surveillance program } \\
\text { while implementing procedures } \\
\text { are being developed. } \\
\text { 2.6.1.2 Safety personnel to } \\
\text { participate a mentors in the } \\
\text { FDH sponsored "pre-job Safety } \\
\text { Briefing Mentoring " Program. } \\
\text { FM - Rober Giroir } \\
\text { OPN - Paul Crane } \\
\text { QA - Dave Vance } \\
\text { OS - Nancie Daniel }\end{array}$ & $\begin{array}{l}\text { Interim Surveillance activities have started. However, } \\
\text { Construction forces activities are nearly complete at the } \\
\text { present time. Attention needs to be maintained to ensure } \\
\text { completion of this corrective action and an ongoing } \\
\text { program for future construction monitoring actions. The } \\
\text { program/process is still being developed and is incomplete } \\
\text { at this time. While this is a safety commitment the } \\
\text { program could be strengthened by teaming with QA, } \\
\text { Environ. Compliance, and Conduct of Opns. staff. The } \\
\text { mentoring corrective action was closed } 4 / 1 / 97 \text { and the } \\
\text { letter describing the program was issued to FDH April 3, } \\
\text { 1997. There have been four mentoring sessions conducted } \\
\text { by Gary Mickle with four more scheduled. The program } \\
\text { will be evaluated quarterly. }\end{array}$ & $\mathbf{X}$ \\
\hline $\begin{array}{l}\text { 15) FEB ASSESSMENT } \\
2.7 .1 \\
\text { Training }\end{array}$ & $\begin{array}{l}\text { 2.7.1.1 Develop a } \\
\text { comprehensive training } \\
\text { evaluation program. }\end{array}$ & $\begin{array}{l}\text { Performance indicators include training scheduled } 60 \text { days } \\
\text { in advance, courses planned v.s. courses taught, TMX } \\
98 \% \text { training currency, and Occurrence Reports with } \\
\text { training findings. A random test generation method is } \\
\text { being developed. The Certification program upgrade for } \\
\text { both operators and trainers is on track with all } \\
\text { commitments scheduled for completion by } 9 / 30 / 97 \text {. }\end{array}$ & $\mathbf{X}$ \\
\hline $\begin{array}{l}\text { 16) FEB ASSESSMENT } \\
\text { 2.8.1 } \\
\text { Emergency Preparedness }\end{array}$ & $\begin{array}{l}\text { 2.8.1.1 Sched. and perform } \\
\text { contamination spread/spill drills } \\
\text { FM - Robert Giroir } \\
\text { OPS - Paul Crane } \\
\text { TRN - Kent McDonald }\end{array}$ & $\begin{array}{l}\text { Drills have been scheduled and are conducted once per } \\
\text { month minimum. Drill critiques are performed and } \\
\text { communicated. Revision of Building Emergency Plans and } \\
\text { Hazards Assessments performance criteria are scheduled } \\
\text { for completion } 5 / 30 / 97 \text {. Drill effectiveness is still } \\
\text { marginal and is being worked to upgrade. The procedure } \\
\text { to ensure re-stocking of spill kits following their use is } \\
\text { scheduled to be upgraded by } 5 / 30 / 97 \text {. }\end{array}$ & $\mathbf{X}$ \\
\hline
\end{tabular}




\begin{tabular}{|c|c|c|c|}
\hline $\begin{array}{l}\text { 17) FEB ASSESSMENT } \\
2.10 .1 \\
\text { QA Program }\end{array}$ & $\begin{array}{l}\text { 2.10.1.1 Assess the SWO QA } \\
\text { Program implementation status } \\
\text { to determine the extent of } \\
\text { compliance to the criteria of } 10 \\
\text { CFR } 830.120 \text {. Revise CM-5-34 } \\
\text { to incorporate rqmits of QAMS- } \\
\text { 004/80, Revise SAPs to include } \\
\text { the QAMS-005/80 rqmts. } \\
\text { Include annual QA evaluations } \\
\text { of mgt. assessments. } \\
\text { QA - Dave Vance } \\
\text { QA - Don Volkman } \\
\text { FM - Robert Giroir } \\
\text { OPN- Paul Crane } \\
\text { TRN- Kent McDonald }\end{array}$ & $\begin{array}{l}\text { The QA Program is in review. The QAPP is being } \\
\text { revised along with the ongoing revisions to company } \\
\text { procedures, S/RIDS, \& implementation plans. Sampling } \\
\text { and Analysis Plans are scheduled for revision } 5 / 30 / 97 \text {. } \\
\text { The QA Program assessment is scheduled for } 6 / 30 / 97 \text { and } \\
\text { evaluation of Mgt. Assessments is scheduled for } 9 / 30 / 97 \text {. } \\
\text { All those interviewed agree that the QA Program is } \\
\text { adequate but that upgrades are needed to improve its } \\
\text { effectiveness. This will be a major consideration in } \\
\text { development of the company implementation of the soon } \\
\text { to be issued FDH QA Program. }\end{array}$ & $\mathbf{X}$ \\
\hline \multicolumn{2}{|c|}{$\begin{array}{l}\text { 18) FEB ASSESSMENT } \\
2.10 .2 \\
\text { Quality Improvement } 2.10 .2 .1 \text { Evaluate and correct the Corrective } \\
\text { Action Management System to bring it into full compliance with the } \\
\text { QAPP. } \\
\text { QA - Dave Vance } \\
\text { FM - Robert Giroir } \\
\text { OS - Nancie Daniel }\end{array}$} & $\begin{array}{l}\text { The Corrective Action Management system upgrade and } \\
\text { revision is in process with a completion schedule set for } \\
7 / 31 / 97 \text {. The existing system performance is under } \\
\text { Nancie Daniel. }\end{array}$ & $\mathbf{X}$ \\
\hline
\end{tabular}


Core Requirement 7 A systematic review of the facility's conformance to applicable DOE orders has been performed, any nonconformances have been identified, and schedules for gaining compliance have been justified in writing and formally approved.

Criteria: 1. A compliance assessment has been completed, non compliances have been identified, and schedules for gaining compliance have been made.

Approach 1 Review and assess documentation of the facility's compliance assessment.

Approach 2 Review and assess corrective action schedules

\begin{tabular}{|c|c|c|c|c|}
\hline \multirow{2}{*}{$\begin{array}{c}\text { SUBJECT/ACTIVITY } \\
\text { REQUIREMENT REFERENCE }\end{array}$} & \multirow{2}{*}{$\begin{array}{l}\text { EVIDENCE EXAMIIED/ } \\
\text { PERSONNEL CONTACTED }\end{array}$} & \multirow{2}{*}{ OBSERVATIONS/COMMENTS } & \multicolumn{2}{|c|}{ COMPLY } \\
\hline & & & YES & NO \\
\hline $\begin{array}{l}\text { 1. Has a systematic review for compliance } \\
\text { to applicable DOE orders been } \\
\text { performed? }\end{array}$ & $\begin{array}{l}\text { WHC-IP-1120 Rev. } 4 \text { (S/RID) } \\
\text { Phase I and Phase II Assessment for } \\
\text { SWD-S/RID }\end{array}$ & $\begin{array}{l}\text { DOE-RL challenged Phase I. DOE approved corrective action } \\
\text { plan to replace S/RID and Phase I assessment (97-SWT-042) }\end{array}$ & $\mathrm{XX}$ & \\
\hline $\begin{array}{l}\text { 2. Has the review been documented and } \\
\text { is it retrievable? }\end{array}$ & Same as above (1) & Same as above (1) & $\mathrm{XX}$ & \\
\hline $\begin{array}{l}\text { 3. Does the assessment examine all } \\
\text { commitments made in the S/RID? }\end{array}$ & $\begin{array}{l}\text { Phase I Assessment } \\
887700-D C D-002 \text { Self Assessment } \\
\text { of SWD Req. }\end{array}$ & Same as above (1) & $\mathrm{XX}$ & \\
\hline $\begin{array}{l}\text { 4. Have areas of noncompliance been } \\
\text { documented? }\end{array}$ & None identified by Phase I & Same as above (1) & $\mathrm{XX}$ & \\
\hline $\begin{array}{l}\text { 5. Were the individuals who performed } \\
\text { the assessment knowledgeable of the } \\
\text { requirements and facility operation? }\end{array}$ & $\begin{array}{l}\text { Letter DC Durban to distribution } \\
\text { "SWD Requirement Self-Assessiment } \\
887700 \text {-DCD-001" } \\
\text { A.E. Aughey }\end{array}$ & $\begin{array}{l}\text { Expert were selected and appointed by facility management for } \\
\text { expertise in specific functional areas. }\end{array}$ & $\mathrm{XX}$ & \\
\hline $\begin{array}{l}\text { 6. Were all requirements in the SWD } \\
\text { S/RIDs presented to a SME for } \\
\text { compliance consideration? }\end{array}$ & AE Aughey & $\begin{array}{l}\text { All requirements were reviewed by the facility SME and facility } \\
\text { manager. }\end{array}$ & $\mathrm{XX}$ & \\
\hline $\begin{array}{l}\text { 7. Was a definitive response returned on } \\
\text { all queries? }\end{array}$ & AE Aughey & Specific responses were returned for all queries. & $\mathrm{XX}$ & \\
\hline $\begin{array}{l}\text { 8. Does a compliance Review Corrective } \\
\text { Action Schedule exist? }\end{array}$ & $\begin{array}{l}\text { RFSH-9750224 } \\
\text { Corrective Action Plan for replacing } \\
\text { SWD-S/RID and Phase I } \\
\text { Assessment. }\end{array}$ & $\begin{array}{l}\text { S/RID due to FDH } 7 / 18 / 97 \\
\text { Phase I due FDH } 1 / 16 / 97\end{array}$ & $\mathrm{XX}$ & \\
\hline
\end{tabular}




\section{READINESS REVIEW EMERGENCY MANAGEMENT CORE REQUIREMENT 8.1}

CORE REQUIREMENT: 8.1 There is an adequate emergency preparedness organization and program.

\section{CRITERIA:}

8.1.1 Emergency and off-normal procedures effectively guide personnel in responding to single and multiple events. APPROACH: 1,2

KEY:

* 1= HNF-SD-WM-ISB-007, CWC Safety Basis.

* 2= WHC-SD-PRP-HA-010, Sol id Waste Burial Ground/Central Waste Complex Hazard Assessment.

* $3=$ HFN-IP-0263-CWC, BEP for CWC.

* 4= HNF-PR-000424, Maintaining Facility Emergency Preparedness.

* 5= DOE-0223, Emergency Plan Implementing Procedure.

* $6=$ WHC-IP-GEN, Guidance and format for Building Emergency Plans.

* 7= WHC-IP-1018, Emergency Prep Program P1an.

* $8=$ WHC-CM-5-34, 1.5 Emergency/Operational Drill Program.

\begin{tabular}{|c|c|c|c|}
\hline CRITERIA & $\begin{array}{l}\text { REFERENCE } \\
\text { DOCUMENTS }\end{array}$ & ASSESSMENT & ACTION ITEMS \\
\hline $\begin{array}{l}\text { 8.1.1.1 current copies of } \\
\text { emergency management } \\
\text { documentation (building } \\
\text { emergency plan; and } \\
\text { emergency recognition and } \\
\text { classification, protective } \\
\text { action guidance and initial } \\
\text { emergency response } \\
\text { procedures are available } \\
\text { to the building emergency } \\
\text { response organization. } \\
\text { DOE 5500.3A, Section } \\
11 . \text { d. (1)] }\end{array}$ & $\begin{array}{l}* 3 \\
* 5 \\
\text { Charles Davis } \\
\text { Pau1 Crane } \\
\text { Bruce Rodgers } \\
\text { Mike Aichele }\end{array}$ & $\begin{array}{l}\text { Copies are } \\
\text { located in ICP, } \\
\text { On-Ca11 Mgrs. } \\
\text { Briefcase. }\end{array}$ & $\begin{array}{l}\text { Meets Criteria No } \\
\text { Action Required. }\end{array}$ \\
\hline
\end{tabular}




\begin{tabular}{|c|c|c|c|}
\hline $\begin{array}{l}\text { 8.1.1.2 Current copies of } \\
\text { the building emergency plan } \\
\text { are available to the } \\
\text { building occupants for } \\
\text { their review. [HNF-PR- } \\
\text { 000424] }\end{array}$ & $\begin{array}{l}\text { * } 3 \\
\text { Charles Davis } \\
\text { Bruce Rodgers } \\
\text { Paul Crane }\end{array}$ & $\begin{array}{l}\text { Copies are } \\
\text { located in ICP, } \\
\text { On-Call Mgrs. } \\
\text { Briefcase. }\end{array}$ & $\begin{array}{l}\text { Meets Criteria No } \\
\text { Action Required. }\end{array}$ \\
\hline $\begin{array}{l}8.1 .1 .3 \text { The current copy } \\
\text { of the facility-specific } \\
\text { "Recognition and } \\
\text { classification of } \\
\text { Emergencies" procedure is } \\
\text { available for use by } \\
\text { emergency response } \\
\text { personne } 7 \text { [D0E } 5500.3 \mathrm{~A} \text {, } \\
\text { Section 11.c. (3); Best } \\
\text { Management Practice] } \\
\text { Note: Although the Site } \\
\text { Emergency Preparedness } \\
\text { organization is responsible } \\
\text { for the issuance of the } \\
\text { facility-specific } \\
\text { "Recognition and } \\
\text { classification of } \\
\text { Emergencies" procedure, the } \\
\text { facility is responsible for } \\
\text { ensuring that the procedure } \\
\text { is implemented during } \\
\text { emergency events. }\end{array}$ & $\begin{array}{l}\text { * } 5 \\
\text { Paul Crane } \\
\text { Charles Davis } \\
\text { Mike Aichele }\end{array}$ & $\begin{array}{l}\text { Copies located } \\
\text { with on-call } \\
\text { managers } \\
\text { briefcase and the } \\
\text { Incident Command } \\
\text { Post. }\end{array}$ & $\begin{array}{l}\text { Meets Criteria No } \\
\text { Action Required. }\end{array}$ \\
\hline
\end{tabular}




\begin{tabular}{|c|c|c|c|}
\hline $\begin{array}{l}\text { 8.1.1.4 The current copy } \\
\text { of the area-specific } \\
\text { "Initial Response for } \\
\text { Declared Emergencies" } \\
\text { procedures is available for } \\
\text { use by emergency response } \\
\text { personnel. [DOE/RL-94-02; } \\
\text { Best Management Practice] } \\
\text { Note: Although the Site } \\
\text { Emergency Preparedness } \\
\text { organization is responsible } \\
\text { for the issuance of the } \\
\text { area-specific "Initial } \\
\text { Response for Declared } \\
\text { Emergencies" procedure, the } \\
\text { facility is responsible for } \\
\text { ensuring that the procedure } \\
\text { is implemented during } \\
\text { emergency events. }\end{array}$ & $\begin{array}{l}\text { * } 5 \\
\text { Paul Crane } \\
\text { Charles Davis } \\
\text { Mike Aichele }\end{array}$ & $\begin{array}{l}\text { Copies located } \\
\text { with on-call } \\
\text { managers } \\
\text { briefcase and the } \\
\text { Incident Command } \\
\text { Post. }\end{array}$ & $\begin{array}{l}\text { Meets Criteria No } \\
\text { Action Required. }\end{array}$ \\
\hline $\begin{array}{l}\text { 8.1.1.5 Provisions and } \\
\text { procedures are in place for } \\
\text { facility evacuation. [DOE } \\
5500.3 \mathrm{~A} \text {, Section } \\
11 . \text { c.(6)(c); DOE/RL-94-02] }\end{array}$ & $\begin{array}{l}* 3 \\
* 5 \\
\text { Charles Davis }\end{array}$ & $\begin{array}{l}\text { Stated in BEP. } \\
\text { Evacuation sirens } \\
\text { are in place for } \\
\text { outside of } \\
\text { building; inside } \\
\text { is by Radio } \\
\text { contact or } \\
\text { runners or pager. }\end{array}$ & $\begin{array}{l}\text { Site evacuation } \\
\text { sirens are not stated } \\
\text { in BEP. } \\
\text { Radio contact in some } \\
\text { areas are poor due to } \\
\text { weak signa7. } \\
\text { Findings in LOI } \\
8.1 .4 .1\end{array}$ \\
\hline $\begin{array}{l}8.1 .1 .6 \text { A system for } \\
\text { personnel accountability is } \\
\text { in place. [DOE } 5500.3 \mathrm{~A} \text {, } \\
\text { Section } 11 . c .(6)(\mathrm{c}) ; \\
\text { DOE/RL-94-02] }\end{array}$ & $\begin{array}{l}* 3 \\
* 5 \\
\text { Charles Davis }\end{array}$ & $\begin{array}{l}\text { Stated in BEP, } \\
\text { staging areas } \\
\text { posted, drills } \\
\text { performed. }\end{array}$ & Meets Criteria. \\
\hline
\end{tabular}




\begin{tabular}{||l|l|l|l||}
\hline $\begin{array}{l}\text { 8.1.1.7 Primary and } \\
\text { aiternate staging areas } \\
\text { have been identified for } \\
\text { the facility. }\end{array}$ & $* 4$ & $\begin{array}{l}\text { Stated in BEP, } \\
\text { signs at staging } \\
\text { area. } \\
\text { observation: The } \\
\text { alternate staging } \\
\text { area or site } \\
\text { evacuation siren } \\
\text { arenot mentioned } \\
\text { in the facility } \\
\text { orientation. }\end{array}$ & $\begin{array}{l}\text { Meets Criteria. } \\
\text { Place the alternate } \\
\text { staging area location } \\
\text { and site evacuation } \\
\text { sirens in facility } \\
\text { orientation. }\end{array}$ \\
$\begin{array}{l}\text { Note: Signs to } \\
\text { direct to staging } \\
\text { area in outer areas. } \\
\text { Good Practice. }\end{array}$ \\
\hline
\end{tabular}


CRITERIA:

8.1.2 An approved emergency plan and supporting documents exist and have been tested to ensure effective emergency preparedness and response. Provisions are in place to upgrade the Emergency Plan based on lessons learned from drills, exercises and actual emergencies. The emergency plan incorporates required emergency preparedness program features.

APPROACH: $2,3,4,7$

\begin{tabular}{|c|c|c|c|}
\hline CRITERIA & $\begin{array}{l}\text { REFERENCE } \\
\text { DOCUMENTS } \\
\end{array}$ & ASSESSMENT & ACTION ITEMS \\
\hline $\begin{array}{l}8.1 .2 .1 \text { The building } \\
\text { emergency plan is based on } \\
\text { facility-specific safety } \\
\text { analyses of potential } \\
\text { abnormal conditions and } \\
\text { covers the range of } \\
\text { credible emergencies. } \\
\text { [DOE 5500.3A, Section } \\
11 . b .(1) ; \text { DOE/RL-94-02] }\end{array}$ & $\begin{array}{l}\text { * } 1 \\
* 3 \\
* 5 \\
* 2 \\
\text { Les Sutton } \\
\text { Charles Davis }\end{array}$ & $\begin{array}{l}\text { Current Hazards } \\
\text { Assessment does } \\
\text { not reflect ISB } \\
\text { event scenario } \\
\text { and consequences } \\
\text { (example, Mixed } \\
\text { Waste drum fire } \\
\text { Beryllium } \\
\text { Concentrations). }\end{array}$ & $\begin{array}{l}\text { Revise Emergency } \\
\text { Plans, Hazards } \\
\text { Assessment and } \\
\text { Emergency Action } \\
\text { Levels to reflect } \\
\text { ISB content as } \\
\text { appropriate. } \\
\text { As referenced in LOI } \\
\text { finding } 8.1 .6 .1 \text {. }\end{array}$ \\
\hline $\begin{array}{l}8.1 .2 .2 \text { The building } \\
\text { emergency plan is updated } \\
\text { or verified at least } \\
\text { annually. [DOE } 5500.3 \mathrm{~A} \text {, } \\
\text { Section } 11 . c .(13)(\mathrm{b}) \text {; } \\
\text { DOE/RL-94-02] }\end{array}$ & $\begin{array}{l}* 3 \\
* 4 \\
\text { Charles Davis } \\
\text { Mike Aichele }\end{array}$ & $\begin{array}{l}\text { Emergency plan } \\
\text { revised and } \\
\text { updated annually. } \\
\text { Current copy date } \\
1 / 8 / 97 \text {, procedure } \\
\text { states on page } \\
\text { one that it will } \\
\text { be updated } \\
\text { annually. }\end{array}$ & $\begin{array}{l}\text { Meets Criteria No } \\
\text { Action Required. }\end{array}$ \\
\hline $\begin{array}{l}\text { 8.1.2.3 The building } \\
\text { emergency plan is approved } \\
\text { by Site Emergency } \\
\text { Management, Hanford Fire } \\
\text { Department, and the } \\
\text { building emergency } \\
\text { director. [DOE/RL-94-02] }\end{array}$ & $\begin{array}{l}* 3 \\
* 4 \\
\text { Charles Davis } \\
\text { Mike Aichele }\end{array}$ & $\begin{array}{l}\text { Approved verified } \\
\text { per HNF-IP-0263- } \\
\text { CWC. The Plan is } \\
\text { reviewed by plant } \\
\text { personnel for } \\
\text { technical content } \\
\text { and lessons } \\
\text { learned from } \\
\text { drills. }\end{array}$ & $\begin{array}{l}\text { Meets Criteria No } \\
\text { Action Required. }\end{array}$ \\
\hline
\end{tabular}




\begin{tabular}{||l|l|l|l||}
\hline $\begin{array}{l}\text { 8.1.2.4 There is a } \\
\text { distribution and control } \\
\text { system which assures that } \\
\text { al] copies of the building } \\
\text { emergency plan is kept } \\
\begin{array}{l}\text { current. [D0E 5500.3A, } \\
\text { Section 11,c. (13)(b); } \\
\text { DOE/RL-94-02] }\end{array}\end{array}$ & $\begin{array}{l}* 3 \\
* 4\end{array}$ & $\begin{array}{l}\text { Copies are } \\
\text { Mike Aichele } \\
\text { through Company } \\
\text { Internal } \\
\text { publication } \\
\text { process. }\end{array}$ & $\begin{array}{l}\text { Meets Criteria No } \\
\text { Action Required. }\end{array}$ \\
$\begin{array}{l}\text { 8.1.2.5 An electronic copy } \\
\text { of the approved building } \\
\text { emergency plan is sent to } \\
\text { Site Emergency Management } \\
\text { for publication on the } \\
\text { Hanford Local Area Network } \\
\text { (HLAN). }\end{array}$ & $\begin{array}{l}* 3 \\
* 4\end{array}$ & $\begin{array}{l}\text { The Emergency } \\
\text { Mike AicheTe } \\
\text { on HLAN. }\end{array}$ & $\begin{array}{l}\text { Meets Criteria No } \\
\text { Action Required. }\end{array}$ \\
\hline
\end{tabular}

\section{CRITERIA:}

8.1.3 Facility Emergency Response personnel are trained to effectively respond and mitigate the consequences of emergencies (assessed under Core Requirement 2 and 3 , provided here for information and completeness). Facility nonemergency response personnel are adequately trained on emergencies situations (assessed under Core Requirement 2 and 3 , provided here for information and completeness). Non-facility emergency response personnel are trained to respond to and support CWC. NOTE: only training that is unique to CWC or describes CWC's operations is to be assessed.

\section{APPROACH: 5,9}

\begin{tabular}{||c|c|c|c|}
\hline CRITERIA & $\begin{array}{c}\text { REFERENCE } \\
\text { DOCUMENTS }\end{array}$ & ASSESSMENT & ACTION ITEMS \\
\hline
\end{tabular}




\begin{tabular}{|c|c|c|c|}
\hline $\begin{array}{l}8.1 .3 .1 \text { A program is } \\
\text { established for the initial } \\
\text { and ongoing training of } \\
\text { emergency response } \\
\text { personnel appointed by the } \\
\text { building emergency } \\
\text { director [DOE } 5500.3 \mathrm{~A}, \\
\text { Section } 11 . c .(11)(\mathrm{b}) ; \\
\text { DOE/RL-94-02] } \\
\text { NOTE: The site Emergency } \\
\text { Management organization is } \\
\text { responsible for } \\
\text { establishing and } \\
\text { maintaining the building } \\
\text { emergency director and bomb } \\
\text { search team training } \\
\text { program. }\end{array}$ & $\begin{array}{l}* 3 \\
* 4 \\
\text { Charles Davis } \\
\text { Mike Aichele } \\
\text { Mary McLellan } \\
\text { Marvene } \\
\text { McChesney }\end{array}$ & $\begin{array}{l}\text { BED trained by } \\
\text { site EP. } \\
\\
\text { BEO trained by } \\
\text { SWM Training } \\
\text { Package. } \\
\text { Accountability } \\
\text { Aides, Building } \\
\text { Sweeps trained by } \\
\text { SWM training. }\end{array}$ & Meets Criteria. \\
\hline $\begin{array}{l}\text { 8.1.3.2 All members of the } \\
\text { building emergency response } \\
\text { organization receive } \\
\text { initial training before } \\
\text { participation. Skill } \\
\text { levels and skills that must } \\
\text { be demonstrated are } \\
\text { identified, completed, and } \\
\text { documented prior to } \\
\text { assignment to perform the } \\
\text { task independently. [DOE } \\
\text { 5500.3A, Section } \\
\text { l1.c. (11) (b); D0E/RL-94-02] } \\
\text { NOTE: Course \#02028B for } \\
\text { initial building emergency } \\
\text { director training; course } \\
\text { \#037510. }\end{array}$ & $\begin{array}{l}* 3 \\
* 4 \\
\text { Charles Davis } \\
\text { Mike Aichele } \\
\text { Mary McLennan } \\
\text { Marvene } \\
\text { McChesney }\end{array}$ & $\begin{array}{l}\text { Training } \\
\text { performed before } \\
\text { personnel are } \\
\text { assigned to } \\
\text { position. }\end{array}$ & $\begin{array}{l}\text { Good Practice. } \\
\text { Accountability } \\
\text { aides perform a } \\
\text { drill at end of } \\
\text { class. } \\
\text { Meets Criteria. }\end{array}$ \\
\hline
\end{tabular}




\begin{tabular}{|c|c|c|c|}
\hline $\begin{array}{l}8.1 .3 .3 \text { A11 members of the } \\
\text { building emergency response } \\
\text { organization participate in } \\
\text { continuing training on at } \\
\text { least an annua] basis. } \\
\text { [DOE } 5500.3 A \text {, Section } \\
11 . c(12)(d) ; \text { DOE } / R L-94-02]\end{array}$ & $\begin{array}{l}* 3 \\
* 4 \\
\text { Charles Davis } \\
\text { Mike Aichele } \\
\text { Mary McLennan } \\
\text { Marvene } \\
\text { McChesney }\end{array}$ & $\begin{array}{l}\text { Personnel are } \\
\text { trained per \# } \\
037510 \text { (BED } \\
\text { training), } 301740 \\
\text { (Haz. Comm. Trng) } \\
\text { and } 301750 \text { (event } \\
\text { command post } \\
\text { trng.) }\end{array}$ & Meets Criteria. \\
\hline $\begin{array}{l}8.1 .3 .4 \text { Training records } \\
\text { for each individual } \\
\text { appointed by the building } \\
\text { emergency director are } \\
\text { maintained per requirements } \\
\text { of the training program. } \\
\text { [DOE } 5500.3 \mathrm{~A} \text {, Section } \\
\text { I1.c. (11) (b)] } \\
\text { NoTE: The Site Emergency } \\
\text { Management organization is } \\
\text { responsible for submitting } \\
\text { the building emergency } \\
\text { director and bomb search } \\
\text { team training records. }\end{array}$ & $\begin{array}{l}* 3 \\
* 4 \\
\text { Charles Davis } \\
\text { Mike Aichele } \\
\text { Mary McLennan } \\
\text { Marvene } \\
\text { McChesney }\end{array}$ & $\begin{array}{l}\text { Lesson Plans, } \\
\text { Course Completion } \\
\text { Rosters, TMX } \\
\text { referenced, no } \\
\text { abnormalities } \\
\text { noted. }\end{array}$ & Meets Criteria. \\
\hline $\begin{array}{l}8.1 .3 .5 \text { The facility } \\
\text { personnel have reviewed the } \\
\text { building emergency plan } \\
\text { within } 30 \text { days after } \\
\text { assignment to the building } \\
\text { and annually thereafter. }\end{array}$ & $\begin{array}{l}* 3 \\
* 4 \\
\text { Charles Davis } \\
\text { Mike Aichele } \\
\text { Mary McLennan } \\
\text { Marvene } \\
\text { McChesney }\end{array}$ & $\begin{array}{l}\text { Personnel } \\
\text { annually review } \\
\text { plan as per } \\
\text { Hazards } \\
\text { Communication } \\
\text { Class \# } 301740 .\end{array}$ & Meets Criteria. \\
\hline $\begin{array}{l}\text { 8.1.3.6 Facility personnel } \\
\text { completing a review of the } \\
\text { building emergency plan is } \\
\text { documented on the Facility } \\
\text { Emergency and Hazard } \\
\text { Information Checklist and } \\
\text { forwarded to the contractor } \\
\text { training records program. }\end{array}$ & $\begin{array}{l}* 3 \\
* 4 \\
\text { Charles Davis } \\
\text { Mike Aichele } \\
\text { Mary McLennan } \\
\text { Marvene } \\
\text { McChesney }\end{array}$ & $\begin{array}{l}\text { Exempt from } \\
\text { Checklist use } \\
\text { Hazards } \\
\text { Communication } \\
\text { Class \# } 301740 .\end{array}$ & Meets Criteria. \\
\hline
\end{tabular}




\section{CRITERIA:}

8.1.4 Facilities, equipment, and resources are in place and adequate to support emergency response operations and ensure the protection of all personne1 (e.g., Emergency operations Center, backup or alternative facilities, primary and backup communication, alarm adequate to notify personnel, transportation, medical treatment, respiratory equipment, exposure controls, instrumentation to measure exposure, etc.

\section{APPROACH: 5}

\begin{tabular}{|c|c|c|c|}
\hline CRITERIA & $\begin{array}{l}\text { REFERENCE } \\
\text { DOCUMENTS } \\
\end{array}$ & ASSESSMENT & ACTION ITEMS \\
\hline $\begin{array}{l}8.1 .4 .1 \text { Alarms notify a11 } \\
\text { affected personnel of } \\
\text { emergencies. Plant } \\
\text { announcing systems ensure } \\
\text { full coverage of the } \\
\text { facility. [29CFR1910 Part } \\
165 \text { (b)(1)] }\end{array}$ & $\begin{array}{l}* 3 \\
\text { Charles Davis }\end{array}$ & $\begin{array}{l}\text { Site wide sirens } \\
\text { ensure adequate } \\
\text { coverage. } \\
\text { Personnel inside } \\
\text { facility are also } \\
\text { covered by two- } \\
\text { way radio and } \\
\text { pager. }\end{array}$ & $\begin{array}{l}\text { Two-way radio } \\
\text { signals are weak or } \\
\text { non existent in } \\
\text { some areas. } \\
\text { Suggest upgrade to } \\
\text { two-way radio } \\
\text { system. }\end{array}$ \\
\hline $\begin{array}{l}8.1 .4 .2 \text { Preventative } \\
\text { maintenance is performed on } \\
\text { evacuation/take cover } \\
\text { alarms by the responsible } \\
\text { maintenance organization in } \\
\text { accordance with established } \\
\text { preventative maintenance } \\
\text { procedures. [DOE } 5500.3 \mathrm{~A} \text {, } \\
\text { Section } 11 . c .(10)(\mathrm{d})\end{array}$ & $\begin{array}{l}\text { * } 3 \\
\text { Charles Davis } \\
\text { Mike Aichele }\end{array}$ & $\begin{array}{l}\text { Site wide sirens } \\
\text { are audibly } \\
\text { tested monthly } \\
\text { and } \\
\text { electronically } \\
\text { tested weekly as } \\
\text { per Statement of } \\
\text { Work, Maintenance } \\
\text { and Monitoring of } \\
\text { the Hanford Site } \\
\text { Emergency } \\
\text { Alerting System. }\end{array}$ & Meets Criteria. \\
\hline
\end{tabular}




\begin{tabular}{|c|c|c|c|}
\hline $\begin{array}{l}8.1 .4 .3 \text { Evacuation/take } \\
\text { cover alarms are audibly } \\
\text { tested at a predesignated } \\
\text { time each month. This } \\
\text { requirement is incorporated } \\
\text { into preventative } \\
\text { maintenance programs. [OOE } \\
5500.3 \mathrm{~A} \text {, Section } \\
11 . c(10)(\mathrm{d})]\end{array}$ & $\begin{array}{l}* 3 \\
\text { Charles Davis } \\
\text { Mike Aichele }\end{array}$ & $\begin{array}{l}\text { Site wide sirens } \\
\text { are audibly } \\
\text { tested monthly } \\
\text { and } \\
\text { electronically } \\
\text { tested weekly as } \\
\text { per Statement of } \\
\text { Work, Maintenance } \\
\text { and Monitoring of } \\
\text { the Hanford Site } \\
\text { Emergency } \\
\text { Alerting System. }\end{array}$ & Meets Criteria. \\
\hline $\begin{array}{l}8.1 .4 .4 \text { Emergency } \\
\text { equipment, as identified in } \\
\text { the respective building } \\
\text { emergency plan, is } \\
\text { inventoried, tested, and } \\
\text { serviced on a periodic } \\
\text { basis. Inventories and } \\
\text { tests are documented (and } \\
\text { posted where applicable). } \\
\text { [DOE } 5500.3 \mathrm{~A} \text {, Section } \\
11 . c .(10)(\mathrm{d})]\end{array}$ & $\begin{array}{l}* 3 \\
\text { Charles Davis } \\
\text { Mike Aichele }\end{array}$ & $\begin{array}{l}\text { The Emergency } \\
\text { Plan does not } \\
\text { give specific } \\
\text { locations of } \\
\text { emergency } \\
\text { equipment. } \\
\text { Spill control } \\
\text { kits are locked } \\
\text { with wire ties } \\
\text { which cannot be } \\
\text { broken without } \\
\text { tools. Should be } \\
\text { able to break and } \\
\text { open by hand. } \\
\text { Not al spill } \\
\text { kits have } \\
\text { inventory sheets } \\
\text { in cabinets. } \\
\text { Radiological } \\
\text { posting signs are } \\
\text { outdated. }\end{array}$ & $\begin{array}{l}\text { Give specific } \\
\text { locations of } \\
\text { emergency equipment } \\
\text { in Emergency Plan. } \\
\text { Replace wire ties } \\
\text { with break away } \\
\text { ties. } \\
\text { Replace missing } \\
\text { inventory sheets. } \\
\text { Replace Rad. signs } \\
\text { with current site } \\
\text { wide approved } \\
\text { signs. }\end{array}$ \\
\hline
\end{tabular}




\begin{tabular}{|c|c|c|c|}
\hline $\begin{array}{l}8.1 .4 .5 \text { The building } \\
\text { emergency director has } \\
\text { ensured that vehicles are } \\
\text { available to move all } \\
\text { personnel from the } \\
\text { facility. This may be } \\
\text { accomplished by a } \\
\text { combination of government- } \\
\text { owned and private vehicles. } \\
\text { [DOE/RL-94-02] }\end{array}$ & $\begin{array}{l}\text { * } 3 \\
\text { Paul Crane } \\
\text { Charles Davis } \\
\text { Mike Aichele }\end{array}$ & $\begin{array}{l}\text { Staging Area } \\
\text { Manager requires } \\
\text { personnel at } \\
\text { staging area to } \\
\text { account for keys } \\
\text { and number of } \\
\text { personnel per } \\
\text { vehicle. }\end{array}$ & Meets Criteria. \\
\hline $\begin{array}{l}\text { 8.1.4.6 Utility } \\
\text { disconnects identified in } \\
\text { the building emergency plan } \\
\text { are properly labeled in the } \\
\text { building. [Best Management } \\
\text { Practice] }\end{array}$ & $\begin{array}{l}\text { * } 3 \\
\text { Paul Crane } \\
\text { Charles Davis } \\
\text { Mike Aichele }\end{array}$ & $\begin{array}{l}\text { Utility } \\
\text { disconnects are } \\
\text { stated in BEP for } \\
\text { location. There } \\
\text { are no disconnect } \\
\text { ID numbers } \\
\text { stated. }\end{array}$ & $\begin{array}{l}\text { Revise Emergency } \\
\text { Plan or Guide to } \\
\text { list specific ID } \\
\text { numbers for } \\
\text { electrical } \\
\text { disconnects. }\end{array}$ \\
\hline
\end{tabular}




\section{CRITERIA :}

8.1.5 Provisions and procedures are in place to support correct classification of emergencies, assessment of consequences, notification of emergency response personne1, and to recommend appropriate protective actions.

APPROACH: 8

\begin{tabular}{|c|c|c|c|}
\hline CRITERIA & $\begin{array}{l}\text { REFERENCE } \\
\text { DOCUMENTS }\end{array}$ & ASSESSMENT & ACTION ITEMS \\
\hline $\begin{array}{l}8.1 .5 .1 \text { The current copy } \\
\text { of the facility-specific } \\
\text { "Recognition and } \\
\text { Classification of } \\
\text { Emergencies" procedure is } \\
\text { avai]able for use by } \\
\text { emergency response } \\
\text { personne1. [D0E } 5500.3 A \text {, } \\
\text { Section 11.c. (3); DOE/RL- } \\
\text { 94-02; Best Management } \\
\text { Practice] } \\
\text { Note: Although the Site } \\
\text { Emergency Preparedness } \\
\text { organization is responsible } \\
\text { for the issuance of the } \\
\text { facility-specific } \\
\text { "Recognition and } \\
\text { Classification of } \\
\text { Emergencies" procedure, the } \\
\text { facility is responsible for } \\
\text { ensuring that the procedure } \\
\text { is implemented during } \\
\text { emergency events. }\end{array}$ & $\begin{array}{l}\text { * } 3 \\
\text { * } 5 \\
\text { Paul Crane } \\
\text { Mike Aichele } \\
\text { Charles Davis }\end{array}$ & $\begin{array}{l}\text { Copies are } \\
\text { located at the } \\
\text { ICP and on-cal1 } \\
\text { Mgrs. Briefcase. }\end{array}$ & Meets Criteria. \\
\hline
\end{tabular}




\section{CRITERIA :}

8.1.6 Hazard assessment are prepared, documented, and maintained which considers emergency events that could affect CWC.

\section{APPROACH: 6,8}

\begin{tabular}{|c|c|c|c|}
\hline CRITERIA & $\begin{array}{l}\text { REFERENCE } \\
\text { DOCUMENTS }\end{array}$ & ASSESSMENT & ACTION ITEMS \\
\hline $\begin{array}{l}\text { 8.1.6.1 The building } \\
\text { emergency plan is based on } \\
\text { facility-specific safety } \\
\text { analyses of potential } \\
\text { abnormal conditions and } \\
\text { covers the range of } \\
\text { credible emergencies. } \\
\text { [DOE 5500.3A, Section } \\
\text { l1.b.(1); DOE/RL-94-02] }\end{array}$ & $\begin{array}{l}* 1 \\
* 2 \\
* 3 \\
* 5 \\
\text { Charies Davis }\end{array}$ & $\begin{array}{l}\text { Current Hazards } \\
\text { Assessment does } \\
\text { not reflect ISB } \\
\text { event scenario } \\
\text { and consequences } \\
\text { (example, Mixed } \\
\text { Waste drum fire } \\
\text { Beryllium } \\
\text { Concentrations). }\end{array}$ & $\begin{array}{l}\text { Revise Emergency } \\
\text { Plans, Hazards } \\
\text { Assessment and } \\
\text { Emergency Action } \\
\text { Levels to reflect } \\
\text { ISB content as } \\
\text { appropriate. }\end{array}$ \\
\hline
\end{tabular}




\begin{tabular}{|c|c|c|c|}
\hline $\begin{array}{l}8.1 .6 .2 \text { The current copy } \\
\text { of the facility-specific } \\
\text { "Recognition and } \\
\text { Classification of } \\
\text { Emergencies" procedure is } \\
\text { available for use by } \\
\text { emergency response } \\
\text { personnel. [DOE 5500.3A, } \\
\text { Section li.c. (3); Best } \\
\text { Management Practice] } \\
\text { Note: Although the Site } \\
\text { Emergency Preparedness } \\
\text { organization is responsible } \\
\text { for the issuance of the } \\
\text { facility-specific } \\
\text { "Recognition and } \\
\text { Classification of } \\
\text { Emergencies" procedure, the } \\
\text { facility is responsible for } \\
\text { ensuring that the procedure } \\
\text { is implemented during } \\
\text { emergency events. }\end{array}$ & $\begin{array}{l}* 1 \\
* 2 \\
* 3 \\
* 5 \\
\text { Charies Davis } \\
\text { Mike Aichele }\end{array}$ & $\begin{array}{l}\text { The current } \\
\text { Emergency Action } \\
\text { Leve1s reflect } \\
\text { the Hazards } \\
\text { Assessment } \\
\text { current } \\
\text { revisions. } \\
\text { The EAL's are } \\
\text { available to BEO } \\
\text { personnel at the } \\
\text { ICP and the on- } \\
\text { call manager. }\end{array}$ & Meets Criteria. \\
\hline
\end{tabular}




\section{CRITERIA:}

8.1.7 Individuals and alternates are designated to perform all emergency roles using clear lines of succession. APPROACH: 10,1

\begin{tabular}{|c|c|c|c|}
\hline CRITERIA & $\begin{array}{l}\text { REFERENCE } \\
\text { DOCUMENTS }\end{array}$ & ASSESSMENT & ACTION ITEMS \\
\hline $\begin{array}{l}8.1 .7 .1 \text { Individuals and } \\
\text { aiternates are designated } \\
\text { to perform all emergency } \\
\text { roles. [DOE } 5500.3 \mathrm{~A} \text {, } \\
\text { Section 11.c.1] }\end{array}$ & $\begin{array}{l}* 3 \\
* 4 \\
\text { Mike Aichele } \\
\text { Charles Davis }\end{array}$ & $\begin{array}{l}\text { The Solid Waste } \\
\text { Management } \\
\text { Authorization } \\
\text { Listing of } \\
\text { Emergency } \\
\text { Personnel } \\
\text { designates } \\
\text { Building } \\
\text { Emergency } \\
\text { Organization } \\
\text { Personnel. }\end{array}$ & $\begin{array}{l}\text { Meets Criteria No } \\
\text { Action Required. }\end{array}$ \\
\hline $\begin{array}{l}8.1 .7 .2 \text { Responsibilities } \\
\text { for each person in the } \\
\text { building emergency response } \\
\text { organization are well } \\
\text { defined. [DOE } 5500.3 \mathrm{~A} \text {, } \\
\text { Section 11.C.1] }\end{array}$ & $\begin{array}{l}\text { * } 3 \\
\text { Mike Aichele } \\
\text { Charles Davis }\end{array}$ & $\begin{array}{l}\text { Responsibilities } \\
\text { are defined in } \\
\text { the BEP sections } \\
3.1,3.2 \text {. More } \\
\text { specific } \\
\text { definitions are } \\
\text { in the upcoming } \\
\text { Building } \\
\text { Emergency } \\
\text { Response Guide. }\end{array}$ & $\begin{array}{l}\text { Implement Building } \\
\text { Emergency Response } \\
\text { Guide or more } \\
\text { specific } \\
\text { information in } \\
\text { plan.. }\end{array}$ \\
\hline
\end{tabular}




\begin{tabular}{|c|c|c|c|}
\hline $\begin{array}{l}8.1 .7 .3 \text { Building emergency } \\
\text { response organization } \\
\text { personnel selection is } \\
\text { based on assignments } \\
\text { similar to normal day to } \\
\text { day responsibilities and } \\
\text { the individual's ability to } \\
\text { properly analyze data, } \\
\text { assess situations, and make } \\
\text { decisions under high stress } \\
\text { conditions. [D0E } 5500.3 \mathrm{~A}, \\
\text { Section 11.c.1] }\end{array}$ & $\begin{array}{l}\text { * } 3 \\
\text { Mike Aichele } \\
\text { Charles Davis }\end{array}$ & $\begin{array}{l}\text { Job assignments } \\
\text { were considered } \\
\text { when selecting } \\
\text { emergency } \\
\text { organization } \\
\text { members. BED is } \\
\text { Operations Team } \\
\text { Leads. }\end{array}$ & $\begin{array}{l}\text { Meets Criteria No } \\
\text { Action Required. }\end{array}$ \\
\hline $\begin{array}{l}8.1 .7 .4 \text { Additional support } \\
\text { personnel such as Health } \\
\text { Physics, Maintenance, } \\
\text { Engineering, or Hazardous } \\
\text { Material Coordinators have } \\
\text { been identified as a part } \\
\text { of the building emergency } \\
\text { response organization as } \\
\text { needed. }\end{array}$ & $\begin{array}{l}* 3 \\
\text { Mike Aichele } \\
\text { Charles Davis } \\
\text { Paul Crane }\end{array}$ & $\begin{array}{l}\text { Support Personnel } \\
\text { are identified in } \\
\text { the Authorization } \\
\text { Listing of } \\
\text { Emergency } \\
\text { Personnel for } \\
\text { Solid Waste } \\
\text { Management. }\end{array}$ & $\begin{array}{l}\text { Meets Criteria No } \\
\text { Action Required. }\end{array}$ \\
\hline $\begin{array}{l}8.1 .7 .5 \text { A listing of the } \\
\text { complete building emergency } \\
\text { response organization } \\
\text { including positions, names, } \\
\text { work locations, and } \\
\text { telephone numbers is } \\
\text { maintained separate from } \\
\text { the building emergency plan } \\
\text { in an internally controlled } \\
\text { facility document. }\end{array}$ & $\begin{array}{l}* 3 \\
* 4 \\
\text { Mike Aichele } \\
\text { Charles Davis } \\
\text { PauT Crane }\end{array}$ & $\begin{array}{l}\text { The Authorization } \\
\text { Listing of } \\
\text { Emergency } \\
\text { Personnel for } \\
\text { Solid Waste } \\
\text { Management is } \\
\text { maintained } \\
\text { separately from } \\
\text { emergency plan } \\
\text { and controlled } \\
\text { internally. }\end{array}$ & $\begin{array}{l}\text { Meets Criteria No } \\
\text { Action Required. }\end{array}$ \\
\hline $\begin{array}{l}8.1 .7 .6 \text { Copies of the } \\
\text { complete building emergency } \\
\text { response organization } \\
\text { listing are issued, at a } \\
\text { minimum, to appropriate } \\
\text { facility location and to } \\
\text { Site Emergency Management. }\end{array}$ & $\begin{array}{l}* 3 \\
* 4 \\
\text { Charles Davis }\end{array}$ & $\begin{array}{l}\text { Copies are kept } \\
\text { at the Incident } \\
\text { Command Post, } \\
\text { Briefcase, EOC, } \\
\text { Site Emergency } \\
\text { Procedures. }\end{array}$ & $\begin{array}{l}\text { Meets Criteria No } \\
\text { Action Required. }\end{array}$ \\
\hline
\end{tabular}




\section{Approach:}

1. Interview individuals responsible for implementation of the emergency preparedness program. Ensure that the emergency preparedness program includes the necessary elements of staffing, management support, resources, training, and planning, to cope with emergencies.

2. Review procedures (operations, maintenance, surveillance, RADCON, administrative, etc.) to verify that emergency and off-normal event are sufficiently linked to the emergency plan. Through discussions with operations personnel and facility managers, confirm knowledge of emergency/off-normal operating procedures. During conduct of the ORR evaluate how personnel utilize procedures during event drills.

3. Review the Emergency P1 an and supporting documentation and compare to the requirements of the FSAR, Hea1th and Safety Plan (HASP), Hazards Baseline Assessment, TSR, and CSER. Ensure that provisions are in place to incorporate drills and actual emergency lessons learned into the Emergency Plan.

4. Review procedures and training material for non-facility emergency response personnel (e.g., fire department, ambulance, hazmat team, security, etc.) to assure CWC has been included, noting it's unique processes.

5. Review the Emergency Plan for commitment and definition of facility, equipment, and resources for emergency response. Conduct a site walk through to ensure medical, fire, hazmat, radiological response, and monitoring equipment are in place. Review surveillance procedures for emergency response equipment to ensure their continued maintenance and ensure up-to-date contact names and telephone numbers are provided at a1] times.

6. Interview personnel responsible for classification of emergencies to determine if the classification scheme is consistent with operating procedures and technical specifications.

7. Perform waik down of facilities and equipment, review procedures and interview appropriate onsite and, as necessary, offsite personnel to verify that provisions are adequate and in place for transportation and treatment of contaminated/injured personnel, fire/rescue support, and protection of security personnel during emergencies.

8. Review Hazard Analysis for CWC to ensure a comprehensive hazard assessment has been conducted and that the emergency plan is responsive to the full spectrum of accidents.

9. Review procedures (operations, maintenance, surveil]ance, RADCON, administrative, etc.) to verify that emergency and off-normal event are sufficiently linked to the emergency plan. Through discussions with operators and operations managers, confirm operator knowledge of emergency/off-normal operating procedures. During conduct of the ORR evaluate how personnel utilize procedures during event drills.

10. Ensure up-to-date contact names and telephone numbers are provided at all times. 
Core Requirement 8.2 There is an adequate engineering support organization and program including the cognizant/system engineer approach.

Criteria: 7. Procedure and controls that ensure safe and reliable operations are adequately employed in conduct of engineering activities.

8. Standard engineering practices, principles, convention and approaches are employed.

Approach: 1. Obtain and review programs, processes, and procedures which control engineering work and confirm appropriate checks and balances exist which would preclude or correct errors (e.g., design, procedure, etc.), standard engineering practices and approaches are employed.

2. Interview engineering support personnel to confirm their understanding of governing and applicable programs/procedures. Include confirming their knowledge of applying these programs and procedures.

3. Through discussion with maintenance, operation and management, develop an understanding of the adequacy of engineering. Determine if responsibility for completing work is clearly defined.

\begin{tabular}{|c|c|c|c|}
\hline LINE OF INQUIRY & EVIDENCE EXAMINED & COMMENTS & $\begin{array}{lll}\mathrm{F} & \mathrm{OR} & \mathbf{0} \\
? & & \end{array}$ \\
\hline $\begin{array}{l}\text { Are areas of } \\
\text { responsibility } \\
\text { identified within } \\
\text { engineering? }\end{array}$ & $\begin{array}{l}\text { Mat Irwin, Manager } \\
\text { Staff Knowledge Checkl ist } \\
\text { Technical Basel ine } \\
\text { Description }\end{array}$ & $\begin{array}{l}\text { A11 cog. engineers are required to complete a } \\
\text { staff knowledge checklist. Checklist is generic to } \\
\text { SWM as apposed to area specific, LLBG or CWC. }\end{array}$ & none \\
\hline $\begin{array}{l}\text { Are areas of } \\
\text { responsibility } \\
\text { jdentified within } \\
\text { engineering? }\end{array}$ & $\begin{array}{l}\text { Robin Bushore, Engineer } \\
\text { Staff Knowledge check } 1 \text { ist } \\
\text { required reading/mgr signoff } \\
\text { Technical Baseline } \\
\text { Description }\end{array}$ & Same as above & none \\
\hline
\end{tabular}




\begin{tabular}{|c|c|c|c|}
\hline LINE OF INQUIRY & EVIDENCE EXAMINED & COMMENTS & $\begin{array}{lll}F & \text { OR } & 0 \\
? & & \end{array}$ \\
\hline $\begin{array}{l}\text { Evaluate adequacy of } \\
\text { Engineering Support. }\end{array}$ & Paul Hemsworth, Maintenance & $\begin{array}{l}\text { Paul's response was that engineering support and } \\
\text { response to maintenance for all aspect of project } \\
112 \text { was excellent }\end{array}$ & none \\
\hline $\begin{array}{l}\text { Are standard } \\
\text { engineering } \\
\text { practices/conventions/ } \\
\text { approaches used. }\end{array}$ & $\begin{array}{l}\text { Mat Irwin } \\
\text { WHC-CM-6-1 }\end{array}$ & $\begin{array}{l}\text { CM-6-1 is the guiding document for engineering } \\
\text { procedures at SWM. National standard ANSI, NFPA, } \\
\text { and NEC are used as necessary. }\end{array}$ & none \\
\hline $\begin{array}{l}\text { Are standard } \\
\text { engineering } \\
\text { practices/conventions/ } \\
\text { approaches used. }\end{array}$ & $\begin{array}{l}\text { Robin Bushore } \\
\text { Technical Basel ine } \\
\text { Description } \\
\text { WHC-CM-6-1 }\end{array}$ & $\begin{array}{l}\text { The Technical baseline establishes history and } \\
\text { reference source documentation of current and } \\
\text { future projects in SWM. WHC-CM-6-1 is the guiding } \\
\text { document for engineering procedures at SWM. } \\
\text { National standard ANSI, NFPA, and NEC are used as } \\
\text { necessary. }\end{array}$ & none \\
\hline
\end{tabular}




\section{PHASE V STORAGE ORR APPRAISAL FORM}

CORE REQUIREMENT 8.3: There is an adequate environmental protection organization and program, to include Air Quality, Surface Water, Groundwater, Solid and Hazardous Waste, Hazardous Materiai Handi ing, Environmentai Ḧonitoring, Hazardous Substance Release Reporting, and Environmental Protection Quality Assurance.

\section{CRITERION 1:}

Environmental Compliance programs are defined in formal policies, standards, and procedures.

\section{APPROACH:}

\begin{tabular}{|c|c|c|c|c|}
\hline \multirow{2}{*}{$\begin{array}{c}\text { SUBJECT / ACTIVITY } \\
\text { REQUIREMENT REFERENCE }\end{array}$} & \multirow{2}{*}{$\begin{array}{l}\text { EVIDENCE EXAMINED/ } \\
\text { PERSONNEL CONTACTED }\end{array}$} & \multirow[t]{2}{*}{ OBSERVATIONS/COMMENTS } & \multicolumn{2}{|c|}{ COMPLY } \\
\hline & & & YES & No \\
\hline $\begin{array}{l}\text { 1, S/RID 20.1) Is Phase V operational } \\
\text { scope completely described in the CWC/SWD } \\
\text { program \& facility operating procedures? } \\
\text { * Are the increases in the safety } \\
\text { envelope and environmental compliance } \\
\text { limits separately evaluated and not } \\
\text { considered as incremental increases of a } \\
\text { continued action [40 CFR 1508.25]? }\end{array}$ & $\begin{array}{l}\text { Interviews with: } \\
\text { Kent McDonald } \\
\text { Brett Barnes } \\
\text { Larry Olsen } \\
\text { Bob Giroir } \\
\text { Read Interim Safety } \\
\text { Basis document (IP- } \\
1120) \text { \& Solid Waste } \\
\text { Technical Baseline (SD- } \\
\text { WM-RPT-060 }\end{array}$ & $\begin{array}{l}\text { Phase } V \text { scope defined in terms of } \\
\text { general CWC strategic } p] \text { lan of } \\
\text { operation and tech baseline. } \\
\text { Buildings } 2404-W A \text {, WB, WC will be } \\
\text { operated to same standards as rest } \\
\text { of CWC storage. } \\
\text { Inventory \& Drum limits defined in } \\
\text { the ISB. Earlier Phases of } \\
\text { storage were operating under pre- } \\
\text { ISB control (FSAR). Now all units } \\
\text { to be administered under the ISB. }\end{array}$ & $x$ & \\
\hline $\begin{array}{l}\text { la, S/RID 20.1) Is the proposed Phase } V \\
\text { operational scope due to a legislative } \\
\text { agreement or court order (eg, TPA)? } \\
\text { * If so, is this requirement noted in the } \\
\text { facility operations program? [WAC 197-11 } \\
\& 352-11 \text { ] }\end{array}$ & $\begin{array}{l}\text { Kent McDonald. } \\
\text { Brett Barnes } \\
\text { Larry 0lsen } \\
\text { Bob Giroir } \\
\text { Referred to Strategic } \\
\text { Plan \& Technical } \\
\text { Baseline document }\end{array}$ & $\begin{array}{l}\text { Not a court order issue. } \\
\text { The new SWD contract rewards } \\
\text { management for reaching final } \\
\text { waste disposal, not storage. } \\
\text { Facility operating policy will be } \\
\text { to output wastes as efficiently as } \\
\text { possible to final disposal. }\end{array}$ & & $\mathrm{n} / \mathrm{a}$ \\
\hline
\end{tabular}




\section{PHASE V STORAGE ORR APPRAISAL FORM}

CORE REQUIREMENT 8.3: There is an adequate environmental protection organization and program, to include Air Quality, Surface Water, Groundwater, Solid and Hazardous Waste, Hazardous Haterial Handiing, Environmentai Honitoring, Hazardous Substance Release Reporting, and Environmental Protection Quality Assurance.

1b) Has the Phase $V$ scope of operation been evaluated for impacts on the safety basis (ISB)?

* Verify that CWC/SWD Environmental Compliance has reviewed Phase $V$ operating procedures, and determined that they are complete and compliant with the Interim Safety Basis document.

1c, S/RID 20.3) Is a groundwater monitoring protocol in place to monitor possibie contamination release from Phase $V$, or from trenches which may provide wastes received by Phase V?

[WAC 173-303-645]?

* Is the protocol sufficiently sensitive to detect potential Phase $V$ releases to the soil under off-normal operating conditions?

* Has the CWC/SWD monitoring program been evaluated for sufficiency in the past 3 years?

* Have a11 CWC/SWD waste program deficiencies been included on the Hanford Action Tracking system for closure?

\section{Kent McDonaid \\ Brett Barnes \\ Larry 01 sen \\ Bob Giroir}

Examine ISB \& CWC EC Regulatory File Index

B. Barnes

L. Otsen

Examine Site-wide EC Manual (CM-7-5) and WAC 173 sections.
Upgraded safety requirements given comp 1 iance reviews by CWC EC staff; verified that they do not conflict.

CWC EC reviews all new facility operating procedures (POPs), and revisions if the $\operatorname{cog}$ engineer requires it.

Groundwater monitoring is not done by CWC as an individual action. Reliance on the overall GW program under PNNL control for the entire Hanford Site.

This requirement is under review for next version of the S/RID.

Impact potential is negligible per CWC. No GW violations have been reported by $\mathrm{PNNL}$.

See Observation 0.8 .3 .1 .1 


\section{PHASE V STORAGE ORR APPRAISAL FORM}

CORE REQUIREMENT 8.3: There is an adequate environmental protection organization and program, to include Air Quality, Surface Water, Groundwater, Solid and Hazardous Waste, Hazardous Material Handling, Environmental Monitoring, Hazardous Substance Release Reporting, and Environmental Protection Quality Assurance.

\begin{tabular}{|c|c|c|c|c|}
\hline $\begin{array}{l}\text { 1d, S/RID 20.3) Is a procedure in place } \\
\text { to evaluate the CWC potential impact on } \\
\text { ground water contaminant transport as part } \\
\text { of the Hanford site-wide RCRA program? } \\
\text { [WAC } 173-303-645]\end{array}$ & $\begin{array}{l}\text { K. McDonald } \\
\text { B. Barnes }\end{array}$ & $\begin{array}{l}\text { Does not apply specifically to } \\
\text { CWC. }\end{array}$ & & $n / a$ \\
\hline $\begin{array}{l}\text { 1e, S/RID 20.3) Is a procedure in place } \\
\text { to estimate potential radioactive dose to } \\
\text { the maximum individual (on-site and off- } \\
\text { site), as a result of Phase } V \text { operations? } \\
\text { [WAC } 173-480-70]\end{array}$ & B. Barnes & $\begin{array}{l}\text { Not part of CWC EC program. } \\
\text { Responsibility given to Radiation } \\
\text { Protection. } \\
\text { Insufficient time available to } \\
\text { verify this issue. }\end{array}$ & & $n / a$ \\
\hline $\begin{array}{l}\text { If, S/RID 20.6) Is a procedure in place } \\
\text { to evaluate if wastes to be received at } \\
\text { Phase V can be excluded from reporting } \\
\text { requirements under "de minimus" rules? } \\
\text { Are sufficient personnel trained to } \\
\text { implement similar procedures at other } \\
\text { CWC/SWD facilities? [ } 40 \text { CFR } 372.38]\end{array}$ & $\begin{array}{l}\text { K. McDonald } \\
\text { B. Barnes } \\
\text { L. O1sen }\end{array}$ & $\begin{array}{l}\text { Waste containers packaged by } \\
\text { others, containers must meet Waste } \\
\text { Acceptance Criteria (EP-0063-4). } \\
\text { Insufficient time to verify this } \\
\text { issue outside of CWC. }\end{array}$ & & $n / a$ \\
\hline $\begin{array}{l}\text { 1g, S/RID 20.6) Is a procedure in place } \\
\text { for Phase V record keeping? } \\
\text { * Are compliance implementation records } \\
\text { maintained and readily retrievable within } \\
\text { CWC? } \\
\text { * Are sufficient personnel trained to } \\
\text { enable effective implementation? } \\
\text { [ } 40 \text { CFR } 377.10]\end{array}$ & $\begin{array}{l}\text { K. McDonald } \\
\text { B. Barnes } \\
\text { M. McChesney } \\
\text { L. Olsen } \\
\text { J. Skolrud } \\
\text { J. Winterhalder }\end{array}$ & $\begin{array}{l}\text { Records are scattered throughout } \\
\text { the CWC and sometimes the entire } \\
\text { Hanford Site. Record retention } \\
\text { guidelines followed in RIDS. Data } \\
\text { for compliance reporting verified/ } \\
\text { validated by source cog personnel } \\
\text { before publication. Environmental } \\
\text { records indexed in CWC EC files. } \\
\text { This topic reviewed by other ORR } \\
\text { team members, also. }\end{array}$ & $x$ & \\
\hline
\end{tabular}




\section{PHASE V STORAGE ORR APPRAISAL FORM}

CORE REQUIREMENT 8.3: There is an adequate environmental protection organization and program, to include Air Quality, Surface Water, Groundwater, Solid and Hazardous Waste, Hazardous Material Handiing, Environmental Monitoring, Hazardous Substance Release Reporting, and Environmental Protection Quality Assurance.

\begin{tabular}{|l|l|l||}
\hline $\begin{array}{l}\text { Ih, S/RID 20.6) Is a procedure in place } \\
\text { for recording (in facility logs) all } \\
\text { actions taken to manage received waste at } \\
\text { Phase V? }\end{array}$ & $\begin{array}{l}\text { B. Giroir } \\
\text { R. Irwin (Mat) } \\
\text { B. Barnes } \\
\text { Drill Participants }\end{array}$ & $\begin{array}{l}\text { Facility logs being kept. } \\
\text { critique. }\end{array}$ \\
$\begin{array}{l}\text { * Are similar procedures implemented at } \\
\text { other CWC/SWD facilities? }\end{array}$ & $\begin{array}{l}\text { Examine EC facility } \\
\text { inspection checklist of } \\
\text { [WAC 173-303-380] }\end{array}$ & $\begin{array}{l}\text { EC facility inspection checklists } \\
\text { wel1 utilized. } \\
\text { Insufficient time available to } \\
\text { verify effectiveness of drum } \\
\text { tracking in the SWITS. }\end{array}$ \\
\hline
\end{tabular}




\section{PHASE V STORAGE ORR APPRAISAL FORM}

CORE REQUIREMENT 8.3: There is an adequate environmental protection organization and program, to include Air quality, Surface Water, Groundwater, Solid and Hazardous Waste, Hazardous Material Handling, Environmental Monitoring, Hazardous Substance Release Reporting, and Environmental Protection Quality Assurance.

\section{CRITERION 2:}

A plan for monitoring air-effluent sources has been formalized in a document and has received appropriate review and approval.

\section{APPROACH:}

\begin{tabular}{|c|c|c|c|c|}
\hline \multirow{2}{*}{$\begin{array}{c}\text { SUBJECT/ACTIVITY } \\
\text { REQUIREMENT REFERENCE }\end{array}$} & \multirow{2}{*}{$\begin{array}{l}\text { EVIDENCE EXAMINED/ } \\
\text { PERSONNEL CONTACTED }\end{array}$} & \multirow[t]{2}{*}{ OBSERVATIONS/COMMENTS } & \multicolumn{2}{|c|}{ COMPLY } \\
\hline & & & YES & NO \\
\hline $\begin{array}{l}\text { 2) Verify that the waste program has been } \\
\text { suitabiy reviewed to meet the specific air } \\
\text { emission requirements of Phase } V \\
\text { operation. }\end{array}$ & $\begin{array}{l}\text { K. McDonald } \\
\text { B. Barnes } \\
\text { L. OLsen } \\
\text { J. Luke } \\
\text { B. Curn } \\
\text { CWC/EC Files } \\
\text { Central ES Files }\end{array}$ & $\begin{array}{l}\text { Requirements for Phase } V \text { developed } \\
\text { before many of current CWC staff } \\
\text { were involved. Some reviews and } \\
\text { interfacing with State regulators } \\
\text { done by central Environmental } \\
\text { Services organization. CWC EC } \\
\text { files contain evidence that } \\
\text { program requirements were met. }\end{array}$ & $x$ & \\
\hline $\begin{array}{l}\text { 2a) Verify that the air-emission sources } \\
\text { from Phase } V \text { have been evaluated for } \\
\text { potential to emit, and that app]icable } \\
\text { ALARA requirements are incorporated in } \\
\text { facility design. } \\
\text { * Was supporting data submitted for state } \\
\text { review under new air source emissions and } \\
\text { Toxic Air Pollutants? } \\
\text { [WAC 173-400-110 \& WAC 173-400-30] }\end{array}$ & $\begin{array}{l}\text { K. McDonald } \\
\text { B. Barnes } \\
\text { L. OLsen } \\
\text { J. Luke } \\
\text { B. Curn } \\
\text { CWC/EC Files } \\
\text { Central ES Files } \\
\text { Notice of Construction }\end{array}$ & $\begin{array}{l}\text { A formal NOC (RL-95-79) was } \\
\text { submitted to the State on Aug } 29 \text {, } \\
\text { 1995. It was developed as a } \\
\text { cooperative effort between Solid } \\
\text { Waste, and central ES staff. It } \\
\text { contained all necessary estimates } \\
\text { of air emissions data based on the } \\
\text { facility design studies. }\end{array}$ & $x$ & \\
\hline
\end{tabular}




\section{PHASE V STORAGE ORR APPRAISAL FORM}

CORE REQUIREMENT 8.3: There is an adequate environmental protection organization and program, to include Air Quality, Surface Water, Groundwater, Solid and Hazardous Waste, Hazardous Material Handling, Environmental Monitoring, Hazardous Substance Release Reporting, and Environmental Protection Quality Assurance.

\begin{tabular}{|c|c|c|c|c|}
\hline $\begin{array}{l}2 \mathrm{~b} \text {, S/RID } 20.2 \text { ) As a new emission source, } \\
\text { was the facility design subjected to a } \\
\text { Best Available Radioactive Control } \\
\text { Technology (BARCT) review? } \\
\text { * Is any active control method } \\
\text { implemented in the Phase } V \text { building(s) } \\
\text { other than HEPA filtration? } \\
\text { * Was a new source review made in support } \\
\text { of the Air Operation Permit application to } \\
\text { the State regulators [WAC } 173-400-110] \text { ? }\end{array}$ & $\begin{array}{l}\text { K. MCDonaTd } \\
\text { CWC/EC Files } \\
\text { Central ES Files } \\
\text { NEPA/Environmental } \\
\text { Assessment } \\
\text { NOC }\end{array}$ & $\begin{array}{l}\text { Potential scope and impacts were } \\
\text { collected, evaluated and presented } \\
\text { in an environmental Assessment for } \\
\text { comp } 1 \text { iance to NEPA requirements } \\
\text { (D0E/EA-0891, Sept 1995). } \\
\text { The project construction would not } \\
\text { have been a1lowed to proceed, per } \\
\text { project management requirements, } \\
\text { until the BARCT studies had been } \\
\text { completed, and incorporated. } \\
\text { The question of a new-source } \\
\text { review has been identified in a } \\
\text { pre-0RR assessment and is } \\
\text { identified as a Pre-Start Action } \\
\text { for the CWC/EC organization, prior } \\
\text { to accepting wastes into the Phase } \\
V \text { buildings. }\end{array}$ & $X$ & TBD \\
\hline $\begin{array}{l}\text { 2b, S/RID 20.1) Was a Notice of } \\
\text { Construction and/or other communication } \\
\text { prepared and submitted to the State } \\
\text { regulatory agencies, with estimates of } \\
\text { environmental aspects of proposed Phase V } \\
\text { operational workscope? [WAC 197-11-960] }\end{array}$ & NOC examined & $\begin{array}{l}\text { See above response. } \\
\text { Insufficient time was available to } \\
\text { verify content of past reviews. } \\
\text { The FEB assessment found no } \\
\text { deficiencies in the program basis. }\end{array}$ & $x$ & \\
\hline
\end{tabular}




\section{PHASE V STORAGE ORR APPRAISAL FORM}

CORE REQUIREMENT 8.3: There is an adequate environmental protection organization and program, to include Air Quality, Surface Water, Groundwater, Solid and Hazardous Waste, Hazardous Material Handling, Environmental Monitoring, Hazardous Substance Release Reporting, and Environmental Protection Quality Assurance.

\begin{tabular}{|c|c|c|c|c|}
\hline $\begin{array}{l}2 \mathrm{~b}, \text { S/RID } 20.1 \text { ) Were any engineered } \\
\text { barriers required in the design to enable } \\
\text { Phase } V \text { to meet NEPA/SEPA compliance (per } \\
\text { ROD/FONSI or State DNS)? } \\
\text { * If so, were the designs reviewed by the } \\
\text { applicable external engineering oversight } \\
\text { authority [WAC } 352-11 \text { et seq]? }\end{array}$ & NOC exămined & $\begin{array}{l}\text { Irsufficient time was àajlable to } \\
\text { verify project construction files, } \\
\text { for certification of background } \\
\text { studies. No objections were made } \\
\text { by the State regulators to prevent } \\
\text { operation of Phase } V \text { facilities. }\end{array}$ & $x$ & \\
\hline $\begin{array}{l}\text { 2c, S/RID 20.2) Is the Phase } V \text { facility } \\
\text { required to register with the State as a } \\
\text { new air emissions source under WAC 173-401 } \\
\text { for Toxic Air Pollutants, etc? } \\
\text { * If so, is documentation of registration } \\
\text { maintained in the CWC/SWD program records, } \\
\text { as well as supporting "potential to emit" } \\
\text { estimates for normal operational scope } \\
\text { [WAC } 173-400-141 \text { \& }-171] \text { ? }\end{array}$ & $\begin{array}{l}\text { K. McDonald } \\
\text { B. Barnes }\end{array}$ & $\begin{array}{l}\text { This issue on CWC/EC Action } 1 \text { ist, } \\
\text { per pre-ORR assessment. } \\
\text { An observation, } 0.8 .3 .2 .1 \text {, is } \\
\text { submitted on this area. }\end{array}$ & & TBD \\
\hline
\end{tabular}




\section{PHASE V STORAGE ORR APPRAISAL FORM}

CORE REQUIREMENT 8.3: There is an adequate environmental protection organization and program, to include Air Qualjty, Surface Water, Groundwater, Solid and Hazardous Waste, Hazardous Material Handling, Environmental Monitoring, Hazardous Substance Release Reporting, and Environmental Protection Quality Assurance.

\begin{tabular}{|c|c|c|c|c|}
\hline $\begin{array}{l}\text { 2d, S/RID 20.2) Are Phase V operäting } \\
\text { procedures in place to prevent air } \\
\text { emissions or waste inventories from } \\
\text { exceeding approved design and operating } \\
\text { permit limits? } \\
\text { * Are sufficient numbers of facility } \\
\text { workers trained to these procedures? } \\
\text { * Are similar procedures being } \\
\text { implemented effectively at other CWC/SWD } \\
\text { facilities? [WAC } 173-216-110 \text { et seq] }\end{array}$ & $\begin{array}{l}\text { K. McDonaTd } \\
\text { B. Barnes } \\
\text { L. 01sen } \\
\text { B. Giroir } \\
\text { J Skoirud } \\
\text { Examined 1ist of POPS } \\
\text { from HLAN, SWMPROC } \\
\text { directory. } \\
\text { Hanford Site } 1995 \\
\text { Environmental Report }\end{array}$ & $\begin{array}{l}\text { A11 CWC storage buildings operate } \\
\text { under the same procedures and } \\
\text { administrative controls for air } \\
\text { emissions requirements. } \\
\text { CWC operations personnel are } \\
\text { trained to same (safety) basis } \\
\text { criteria for a11 } 24 X X-\text { series } \\
\text { buildings. Buildings are not } \\
\text { required to perform continuous } \\
\text { emissions monitoring. A record } \\
\text { sampler is maintained for the } \\
\text { annual environmental report. }\end{array}$ & $X$ & \\
\hline $\begin{array}{l}2 e, \text { S/RID 20.4) Has an evaluation of } \\
\text { Phase } V \text { operational scope been performed } \\
\text { to determine need to comply with } 40 \text { CFR } 61 \\
\text { registration and monitoring of air } \\
\text { emissions? } \\
\text { * Will the CWC meet threshold requirement } \\
\text { of less than } 10 \text { millirem/year (beta-gamma) } \\
\text { dose to the general public? } \\
\text { * Will the CWC meet threshold requirement } \\
\text { of less than } 25 \text { millirem/year (TRU-alpha) } \\
\text { dose to general public? } \\
\text { [40 CFR 61.92 \& } 191.03 \text { ] }\end{array}$ & $\begin{array}{l}\text { K. McDonald } \\
\text { B. Barnes } \\
\text { L. 01sen }\end{array}$ & $\begin{array}{l}\text { 0perational scope reviewed, per } \\
\text { criteria responses above. } \\
\text { Procedures to evaluate expected } \\
\text { dose are outside the CWC/EC } \\
\text { responsibility. Referred to the } \\
\text { Rad Con organization. Time not } \\
\text { available to verify this issue } \\
\text { further. } \\
\text { Data to support the estimates is } \\
\text { backed up for the Hanford Site } \\
\text { Environmental Report, published by } \\
\text { PNNL, (1atest year 1995, issued } \\
\text { Sept 1996). }\end{array}$ & $X$ & TBD \\
\hline
\end{tabular}




\section{PHASE V STORAGE ORR APPRAISAL FORM}

CORE REQUIREMENT 8.3: There is an adequate environmental protection organization and program, to include Air Quality, Surface Water, Groundwater, Solid and Hazardous Waste, Hazardous Material Handling, Environmental Monitoring, Hazardous Substance Release Reporting, and Environmental Protection Quality Assurance.

\begin{tabular}{|c|c|c|c|c|}
\hline $\begin{array}{l}2 f \text { S/RID 20.4) Has the Phase } V \text { scope of } \\
\text { operations been documented as meeting } \\
\text { ALARA (radioactive emissions) for facility } \\
\text { workers? [WAC 402-10-010] }\end{array}$ & $\begin{array}{l}\text { K. McDonald } \\
\text { B. Barnes } \\
\text { L. Olsen }\end{array}$ & $\begin{array}{l}\text { CWC/EC provides personnel to } \\
\text { attend and participate in ALARA } \\
\text { meetings, lessons learned, safety } \\
\text { briefings, pre-job reviews and } \\
\text { drill critiques. A separate ALARA } \\
\text { plan is not used. }\end{array}$ & $X$ & \\
\hline $\begin{array}{l}2 \mathrm{~g} \text { ) Review goals, procedures, roles \& } \\
\text { responsibilities, training/certifications } \\
\text { and implementing records for air emission } \\
\text { compliance at similar CWC/SWD facilities. } \\
\text { * Coordinate responses and supporting } \\
\text { data with ORR lead reviewer for training. }\end{array}$ & $\begin{array}{l}\text { B. Giroir } \\
\text { K. McDonald }\end{array}$ & $\begin{array}{l}\text { Solid Waste Division maintains a } \\
\text { Strategic Plan and Technical } \\
\text { Baseline for forward planning. } \\
\text { The EC organization interfaces } \\
\text { with other SWD facilities and } \\
\text { other organizations as need and } \\
\text { opportunity requires. Staff are } \\
\text { provided cross-training and other } \\
\text { skills upgrade assistance on a } \\
\text { case-by-case basis. } \\
\text { Sufficient time was not available } \\
\text { to verify details of in these } \\
\text { outside organizations. }\end{array}$ & $x$ & TBD \\
\hline
\end{tabular}


CORE REQUIREMENT 8.3: There is an adequate environmental protection organization and program, to include Air Quality, Surface Water, Groundwater, Sol id and Hazardous Haste, Hazardous Material Handling, Environmental Monitoring, Hazardous Substance Release Reporting, and Environmental Protection Quality Assurance.

\section{CRITERION 3:}

A formal waste program exists, which includes goals, procedures, roles and responsibitities for identifying,

characterizing, and managing all waste streams.

\section{APPROACH :}

\begin{tabular}{|c|c|c|c|c|}
\hline \multirow{2}{*}{$\begin{array}{c}\text { SUBJECT/ACTIVITY } \\
\text { REQUIREMENT REFERENCE }\end{array}$} & \multirow{2}{*}{$\begin{array}{l}\text { EVIDENCE EXAMINED/ } \\
\text { PERSONNEL CONTACTED }\end{array}$} & \multirow[t]{2}{*}{ OBSERVATIONS/COMMENTS } & \multicolumn{2}{|c|}{ COMPLY } \\
\hline & & & YES & NO \\
\hline $\begin{array}{l}\text { 3) Verify that a formal waste program is } \\
\text { documented, including goals, procedures, } \\
\text { roles, training and responsibilities for } \\
\text { identifying, characterizing, and managing } \\
\text { a11 waste streams within the scope of the } \\
\text { CWC Interim Safety Basis document. }\end{array}$ & $\begin{array}{l}\text { K. McDonald } \\
\text { B. Giroir } \\
\text { R. Irwin } \\
\text { B. Barnes } \\
\text { L. Olsen } \\
\text { J. Winterhalder } \\
\\
\text { Strategic Plan/ } \\
\text { Technical Baseline } \\
\text { ISB } \\
\text { POPS }\end{array}$ & $\begin{array}{l}\text { Policy, goals, procedures, } \\
\text { training, inspections, } \\
\text { assessments, critiques all being } \\
\text { followed regularly by the CWC. } \\
\text { Roles and responsibilities are not } \\
\text { uniformly assigned within CWC, but } \\
\text { when outside assistance/expertise } \\
\text { is needed requests can be made to } \\
\text { other SWD and RUST organizations. } \\
\text { Charters of the separate RUST } \\
\text { organizations are being reviewed } \\
\text { in order to optimize staff } \\
\text { effectiveness. This is a good } \\
\text { management practice, and not the } \\
\text { result of an outside requirement. }\end{array}$ & $x$ & \\
\hline
\end{tabular}


PHASE V STORAGE ORR APPRAISAL FORM

CORE REQUIREMENT 8.3: There is an adequate environmental protection organization and program, to include Air Quality, Surface Water, Groundwater, Solid and Hazardous Waste, Hazardous Material Handling, Environmental Monitoring, Hazardous Substance Release Reporting, and Environmental Protection Quality Assurance.

\begin{tabular}{|c|c|c|c|}
\hline $\begin{array}{l}\text { 3a) Verify that similar procedures, and } \\
\text { training are being effectively implemented } \\
\text { for other, similar CWC/SWD facilities. }\end{array}$ & See above. & $\begin{array}{l}\text { The FEB evatuation (Dec 1996) } \\
\text { shows no non-compliance issues in } \\
\text { the environmental protection } \\
\text { program. A finding is submitted } \\
\text { for improvement of non-radioactive } \\
\text { hazards emphasis, as a result of } \\
\text { the 0RR critique of the emergency } \\
\text { drill. }\end{array}$ & TBD \\
\hline $\begin{array}{l}\text { 3b, S/RID 20.2) Is a complete list of } \\
\text { expected input waste streams (including } \\
\text { designations) posted in the Phase } V \\
\text { facility for reference by facility workers } \\
\text { and external oversight personnel? } \\
\text { * Is documentation incorporated in the } \\
\text { Phase V portion of the CWC/SWD Interim } \\
\text { Safety Basis? }\end{array}$ & $\begin{array}{l}\text { K. McDonald } \\
\text { B. Barnes } \\
\text { L. Olsen }\end{array}$ & $\begin{array}{l}\text { Buildings do not list input waste } \\
\text { streams in this manner. The SWITS } \\
\text { and facility logs provide the } \\
\text { nearest equivalent information. } \\
\text { See observation } 0.8 .3 .2 .2\end{array}$ & $x$ \\
\hline $\begin{array}{l}\text { 3c, S/RID 20.2) Will an up-to-date and } \\
\text { comprehensive inventory of stored waste(s) } \\
\text { be maintained at the Phase } V \text { facility? } \\
\text { * Is the composition data for individual } \\
\text { waste containers readily available to } \\
\text { facility and oversight personnel, at } \\
\text { similar CWC/SWD facilities? }\end{array}$ & $\begin{array}{l}\text { K. McDonald } \\
\text { B. Barnes } \\
\text { L. Olsen } \\
\text { B. Giroir }\end{array}$ & $\begin{array}{l}\text { See above comment. Implementation } \\
\text { of this requirement represents a } \\
\text { best management practice under. } \\
\text { "conduct of ops." } \\
\text { See observation } 0.8 .3 .2 .2\end{array}$ & $x$ \\
\hline
\end{tabular}


PHASE V STORAGE ORR APPRAISAL FORM

CORE REQUIREMENT 8.3: There is an adequate environmental protection organization and program, to include Air Quality, Surface Water, Groundwater, Solid and Hazardous Waste, Hazardous Material Handling, Environmental Monitoring, Hazardous Substance Release Reporting, and Environmental Protection Quality Assurance.

\begin{tabular}{|c|c|c|c|c|}
\hline $\begin{array}{l}\text { 3d, S/RID 20.3) Is a procedure in place } \\
\text { to maintain a log of inspection for the } \\
\text { Phase } V \text { stored wastes? } \\
\text { * Are suitable numbers of CWC/SWD } \\
\text { personnel trained to these procedures to } \\
\text { operate Phase } V \text { ? } \\
\text { * Are similar procedures effectively } \\
\text { utilized at other CWC/SWD facilities? }\end{array}$ & $\begin{array}{l}\text { K. McDonald } \\
\text { B. Barnes } \\
\text { L. Olsen } \\
\text { Examine POPs index } \\
\text { Selected POPs } \\
\text { CWC/EC Training file }\end{array}$ & $\begin{array}{l}\text { CWC EC staff are suitably trained; } \\
\text { an EJTA has just been completed in } \\
\text { evaluation of changes/upgrades to } \\
\text { the required training. CWC EC } \\
\text { staff follow approved procedures } \\
\text { for doing facility inspections. } \\
\text { Insufficient time was available to } \\
\text { verify non-EC use of facility log } \\
\text { upkeep. Drill critique did not } \\
\text { indicated that facility log was } \\
\text { consulted during the drill } \\
\text { accident for drum waste contents. }\end{array}$ & $X$ & TBD \\
\hline $\begin{array}{l}\text { 3e, S/RID 20.4) Is a procedure in place } \\
\text { to ensure that Phase } V \text { scope of operations } \\
\text { will meet threshold levels (maximum } \\
\text { contaminant levels) for all other } \\
\text { hazardous chemicals, specified by the } \\
\text { Environmental Protection Agency and the } \\
\text { state Board of Health? [WAC 246-290-310] }\end{array}$ & $\begin{array}{l}\text { B. Barnes } \\
\text { L. Olsen } \\
\text { Examined Hazards } \\
\text { Communication Program } \\
\text { Plan (IP-0845, section } \\
\text { 1.8) }\end{array}$ & $\begin{array}{l}\text { A search of the POPs index did not } \\
\text { show that this issue was directly } \\
\text { being met. Emergence drill } \\
\text { critique indicated this is a } \\
\text { problem area. } \\
\text { A finding is submitted which } \\
\text { includes this issue as part of the } \\
\text { overall hazards awareness actions. }\end{array}$ & & $x$ \\
\hline
\end{tabular}


CORE REQUIREMENT 8.3: There is an adequate environmental protection organization and program, to include Air Quality, Surface Water, Groundwater, Solid and Hazardous Waste, Hazardous Material Handling, Environmental Monitoring, Hazardous Substance Release Reporting, and Environmental Protection Quality Assurance.

\begin{tabular}{|c|c|c|c|c|}
\hline $\begin{array}{l}3 f \text {, S/RID } 20.6 \text { ) Are labeling requirements } \\
\text { for Phase } V \text { wastes being suitably } \\
\text { implemented at other similar CWC/SWD } \\
\text { facilities? } \\
\text { * Are Phase V designation/segregation } \\
\text { requirements being implemented at other } \\
\text { CWC buildings? [40 CFR } 377.10]\end{array}$ & $\begin{array}{l}\text { K. McDonald } \\
\text { B. Barnes } \\
\text { L. 01sen } \\
\text { S. Addelman } \\
\text { Examine EC Inspection } \\
\text { CheckT ist from } 3 / 28 / 97 \\
\text { Solid Waste Acceptance } \\
\text { Criteria (EP-0063-4) }\end{array}$ & $\begin{array}{l}\text { Most CWC EC personnel participate } \\
\text { in the facility walk-down } \\
\text { inspections. Drum labels are one } \\
\text { of the items verified. } \\
\text { The generator is responsible for } \\
\text { proper labels on containers. CWC } \\
\text { may do selected verification and } \\
\text { sampling on an as-needed basis. } \\
\text { Sampling for verification of drum } \\
\text { contents is outside the scope of } \\
\text { the CWC/EC responsibility, as long } \\
\text { as the waste is certified by its } \\
\text { generator as meeting the Sw } \\
\text { acceptance criteria. Insufficient } \\
\text { time was available to verify this } \\
\text { issue outside of CWC Phase V. }\end{array}$ & $X$ & $\mathrm{n} / \mathrm{a}$ \\
\hline $\begin{array}{l}3 g, \text { S/RID 20.4) Is a procedure in place } \\
\text { to limit fugitive emissions (PM-10) from } \\
\text { waste trenches, which may supply waste to } \\
\text { the Phase V facility? [WAC 173-400-040] } \\
\text { * Is the procedure being effectively } \\
\text { implemented for other CWC/SWD facility } \\
\text { receival operations? }\end{array}$ & $\begin{array}{l}\text { B. Barnes } \\
\text { L. 01sen } \\
\text { WAC sections } \\
\text { EC manual (CM-7-5) }\end{array}$ & $\begin{array}{l}\text { Trenches inspected and stabilized } \\
\text { on an as-needed basis, annually as } \\
\text { a minimum. }\end{array}$ & $X$ & \\
\hline
\end{tabular}




\section{PHASE V STORAGE ORR APPRAISAL FORM}

CORE REQUIREMENT 8.3: There is an adequate environmental protection organization and program, to include Air Quality, Surface Water, Groundwater, Solid and Hazardous Waste, Hazardous Material Handling, Environmental Monitoring, Hazardous Substance Release Reporting, and Environmental Protection Quality Assurance.

\section{GRITERION 4 :}

There is a formal Pollution/Waste Minimization Plan.

\section{APPROACH:}

\begin{tabular}{|c|c|c|c|c|}
\hline \multirow{2}{*}{$\begin{array}{c}\text { SUBJECT/ACTIVITY } \\
\text { REQUIREMENT REFERENCE }\end{array}$} & \multirow{2}{*}{$\begin{array}{l}\text { EVIDENCE EXAMINED/ } \\
\text { PERSONNEL CONTACTED }\end{array}$} & \multirow[t]{2}{*}{ OBSERVATIONS/COMMENTS } & \multicolumn{2}{|c|}{ COMPLY } \\
\hline & & & YES & NO \\
\hline $\begin{array}{l}\text { 4) Verify that a pollution prevention/ } \\
\text { waste minimization plan (with goals, } \\
\text { procedures, training \& scheduTes) is in } \\
\text { place for Phase } V \text { facility. }\end{array}$ & $\begin{array}{l}\text { K. McDonald } \\
\text { B. Barnes } \\
\text { L. Olsen } \\
\text { B. Giroir }\end{array}$ & $\begin{array}{l}\text { Phase } V \text { does not have a separate } \\
\text { PP/W-M plan. CWC has chosen to } \\
\text { operate under the Hanford Site- } \\
\text { Wide PP/W-M program. Phase } V \text { will } \\
\text { not stabilize container wastes to } \\
\text { reduce toxicity, availability to } \\
\text { the environment, or reduction of } \\
\text { potential facility worker } \\
\text { exposure/dose. } \\
\text { A1 } 1 \text { similar actions are performed } \\
\text { by either the generator of the } \\
\text { container, by the WRAP facility or } \\
\text { by SwD Generator services. } \\
\text { An observation, } 0.8 .3 .4 .1 \text {, is } \\
\text { submitted for this issue. }\end{array}$ & & $x$ \\
\hline
\end{tabular}




\section{PHASE V STORAGE ORR APPRAISAL FORM}

CORE REQUIREMENT 8.3: There is an adequate environmental protection organization and program, to include Air Quality, Surface Water, Groundwater, Solid and Hazardous Waste, Hazardous Material Handling, Environmental Monitoring, Hazardous Substance Release Reporting, and Environmental Protection Quality Assurance.

\begin{tabular}{|c|c|c|c|}
\hline $\begin{array}{l}4 a, \text { S/RID 20.5) Is the P2/WM plan being } \\
\text { effectively implemented at other CWC/SWD } \\
\text { facilities? } \\
\text { * Does CWC/SWD have a written policy } \\
\text { showing local and corporate management } \\
\text { support for the P2/WM plan objectives? } \\
\text { * Are specific goals and objectives in } \\
\text { place for Phase V during FY 1997? } \\
{[40 \text { CFR } 372.85]}\end{array}$ & $\begin{array}{l}\text { Review S/RIDs and other } \\
\text { drivers. }\end{array}$ & $\begin{array}{l}\text { See above comment: } \\
\text { Insufficient time was available to } \\
\text { verify non-Phase } V \text { implementation } \\
\text { activity. }\end{array}$ & TBD \\
\hline $\begin{array}{l}\text { 4b, S/RID } 20.5 \text { ) Will wastes be treated to } \\
\text { meet compliance requirements (stabilize, } \\
\text { reduce toxicity, availability to } \\
\text { environment, reduce facility worker } \\
\text { radioactive dose, etc) during storage? } \\
\text { * Are sufficient CWC personnel trained to } \\
\text { implement P2/WM program requirements in } \\
\text { Phase V? [WAC } 173-303-030 \text { ] }\end{array}$ & $\begin{array}{l}\text { K. McDonald. } \\
\text { B. Barnes } \\
\text { L. O1sen } \\
\text { B. Giroir }\end{array}$ & $\begin{array}{l}\text { Insufficient time available to } \\
\text { verify implementation outside CWC. } \\
\text { A review effort is underway to } \\
\text { evaluate the S/RID content and } \\
\text { streamline CWC operation in } \\
\text { accordance with the Strategic Plan } \\
\text { and Technical Baseline. }\end{array}$ & TBD \\
\hline
\end{tabular}


CORE REQUIREMENT 8.3: There is an adequate environmental protection organization and program, to include Air Quality, Surface Water, Groundwater, Sol id and Hazardous Waste, Hazardous Material Handling, Environmental Monitoring, Hazardous Substance Release Reporting, and Environmental Protection Quality Assurance.

\section{CRITERION-5}

There is a formal program which defines the inventory control, release prevention, and use of chemicals and toxic materials.

\section{APPROACH:}

\begin{tabular}{|c|c|c|c|c|}
\hline \multirow{2}{*}{$\begin{array}{l}\text { SUBJECT/ACTIVITY } \\
\text { REQUIREMENT REFERENCE }\end{array}$} & \multirow{2}{*}{$\begin{array}{l}\text { EVIDENCE EXAMINED/ } \\
\text { PERSONNEL CONTACTED }\end{array}$} & \multirow[t]{2}{*}{ OBSERVATIONS/COMMENTS } & \multicolumn{2}{|c|}{ COMPLY } \\
\hline & & & YES & NO \\
\hline $\begin{array}{l}\text { 5) Verify documentation exists for a } \\
\text { program which defines the training and use } \\
\text { of chemicals and toxic materials, within } \\
\text { Phase } V \text { and the CWC. }\end{array}$ & $\begin{array}{l}\text { K. Mcdonald } \\
\text { B. Barnes } \\
\text { L. 01sen } \\
\text { S. Addelman } \\
\text { M. McChesney } \\
\text { Examined Hazards } \\
\text { Awareness Program Plan } \\
\text { (IP-0845, section 1.8) }\end{array}$ & $\begin{array}{l}\text { The program and support were } \\
\text { verified and judged adequate. } \\
\text { Selected CWC/EC personnel are } \\
\text { involved in hazards awareness } \\
\text { briefings. Briefings are given } \\
\text { regularly about every } 2 \text { months. } \\
\text { Training and safety attendance } \\
\text { records are maintained by the EC } \\
\text { staff. }\end{array}$ & $x$ & \\
\hline $\begin{array}{l}\text { 5a) Verify that inventory control } \\
\text { procedures are in place for monitoring and } \\
\text { limiting the type and unnecessary quantity } \\
\text { of chemicals and toxic materials } \\
\text { purchased. }\end{array}$ & & $\begin{array}{l}\text { This issue is covered in } P P / W-M \\
\text { activities. CWC currently follows } \\
\text { the site-Wide PP/W-M program. } \\
\text { Insufficient time was available to } \\
\text { verify how SWD/CWC implements } \\
\text { quantity controls on purchases of } \\
\text { hazardous materials. }\end{array}$ & $\mathrm{n} / \mathrm{a}$ & $\mathrm{TBD}$ \\
\hline
\end{tabular}


CORE REQUIREMENT 8.3: There is an adequate environmental protection organization and program, to include Air Quality, Surface Water, Groundwater, Solid and Hazardous Waste, Hazardous Material Handling, Environmental Monitoring, Hazardous Substance Release Reporting, and Environmental Protection Quality Assurance.

\begin{tabular}{|c|c|c|c|}
\hline $\begin{array}{l}\text { 5b) Verify procedures are in place to } \\
\text { prevent/minimize the release of toxic } \\
\text { chemical materials from Phase V to the } \\
\text { environment. Verify implementation at } \\
\text { other cWC facilities. }\end{array}$ & $\begin{array}{l}\text { Emergency Dri1] } \\
\text { Participants and } \\
\text { observers }\end{array}$ & $\begin{array}{l}\text { General level of needs associated } \\
\text { with proper conduct and response } \\
\text { during off-normal operations was } \\
\text { judged inadequate. } \\
\text { Hazards awareness at CWC and } \\
\text { preparations for Phase } V \\
\text { utilization do not give balanced } \\
\text { attention to both radioactive and } \\
\text { non-radioactive sources in the } \\
\text { possible Phase } V \text { waste stream } \\
\text { inputs. } \\
\text { NoTE: on May } 14 \text {, during the Phase } \\
V \text { oRR evaluation, a chemical } \\
\text { explosion occurred at the PFP } \\
\text { facility. This event should } \\
\text { reinforce the on-going need to } \\
\text { improve the chemical hazards } \\
\text { awareness efforts, prior to } \\
\text { stating full Phase V readiness. } \\
\text { A finding, F.8.3.5.1, is submitted } \\
\text { which includes recommendations to } \\
\text { improve non-radioactive hazards } \\
\text { awareness. }\end{array}$ & $x$ \\
\hline
\end{tabular}




\section{PHASE V STORAGE ORR APPRAISAL FORM}

CORE REQUIREMENT 8.3: There is an adequate environmental protection organization and program, to include Air Quality, Surface Water, Groundwater, Solid and Hazardous Waste, Hazardous Material Handi ing, Environmental Monitoring, Hazardous Substance Release Reporting, and Environmental Protection Quality Assurance.

\section{-... CRITERION 6:}

A Response Action Plan or equivalent document is in place, which includes specific responsibilities for, and

procedures to assess, all releases potentially subject to reporting and notification requirements. APPROACH:

\begin{tabular}{|c|c|c|c|c|}
\hline \multirow{2}{*}{$\begin{array}{c}\text { SUBJECT / ACTIVITY } \\
\text { REQUIREMENT REFERENCE }\end{array}$} & \multirow{2}{*}{$\begin{array}{l}\text { EVIDENCE EXAMINED/ } \\
\text { PERSONNEL CONTACTED }\end{array}$} & \multirow[t]{2}{*}{ OBSERVATIONS/COMMENTS } & \multicolumn{2}{|c|}{ COMPLY } \\
\hline & & & YES & NO \\
\hline $\begin{array}{l}\text { 6) Verify that response action plans or } \\
\text { equivalent documents are in place, which } \\
\text { establish the nature and scope of the } \\
\text { response action program. }\end{array}$ & $\begin{array}{l}\text { Emergency Dri11 } \\
\text { Participants \& } \\
\text { Observers }\end{array}$ & $\begin{array}{l}\text { Because of crowded conditions, } \\
\text { this ORR member did not act as an } \\
\text { official observer, but did visit } \\
\text { the lower command post and talk } \\
\text { with the oRR observers prior to } \\
\text { the execution of the drill. Was a } \\
\text { participant in the post drill } \\
\text { debriefing. } \\
\text { The S/RID requirement, to evaluate } \\
\text { or determine notification need to } \\
\text { higher officials was the only } \\
\text { action to estimate air releases. } \\
\text { This is partial basis for } \\
\text { judgement that the drill was } \\
\text { unsatisfactory. } \\
\text { See finding F.8.3.5.1 for other } \\
\text { details. }\end{array}$ & & $x$ \\
\hline
\end{tabular}


PHASE V STORAGE ORR APPRAISAL FORM

CORE REQUTREMENT 8.3: There is an adequate environmental protection organization and program, to include Air Quality, Surface Water, Groundwater, Solid and Hazardous Waste, Hazardous Material Handling, Environmental Monitoring, Hazardous Substance Release Reporting, and Environmental Protection Quality Assurance.

\begin{tabular}{|c|c|c|c|c|}
\hline $\begin{array}{l}6 \mathrm{a}, \text { S/RID } 20.2 \text { ) Are procedures in place } \\
\text { and staff trained to meet monitoring \& } \\
\text { reporting requirements due to Phase } V \\
\text { registration as a point source? }\end{array}$ & $\begin{array}{l}\text { Same as above, } \\
\text { K. McDonald } \\
\text { B. Barnes } \\
\text { J. Skolrud }\end{array}$ & $\begin{array}{l}\text { Records structure is maintained in } \\
\text { the CWC/EC Regulatory Issues file. } \\
\text { Data for compliance reports is } \\
\text { collected and forwarded to central } \\
\text { RUST ES Reports organization. } \\
\text { User guide is available for input/ } \\
\text { retrieval of data from SWITS } \\
\text { database. Desk instructions are } \\
\text { used for compilation of reports, } \\
\text { validation and issuing schedule. }\end{array}$ & $X$ & - \\
\hline $\begin{array}{l}\text { 6b) Verify that CWC/SWD staff understand } \\
\text { responsibilities and procedures to assess } \\
\text { a } 11 \text { Phase } V \text { releases potentially subject } \\
\text { to reporting and notification } \\
\text { requirements. }\end{array}$ & $\begin{array}{l}\text { K. McDonald } \\
\text { M. McChesney }\end{array}$ & $\begin{array}{l}\text { Training program is evaluated } \\
\text { under Core Requirement } 2 \text {. CWC/EC } \\
\text { operation was examined, along with } \\
\text { general level of understanding for } \\
\text { organization staff. ETJAs had } \\
\text { just been completed when the ORR } \\
\text { began. }\end{array}$ & $x$ & \\
\hline
\end{tabular}




\section{PHASE V STORAGE ORR APPRAISAL FORM}

CORE REQUIREMENT 8.3: There is an adequate environmental protection organization and program, to include Air Quality, Surface Water, Groundwater, Solid and Hazardous Waste, Hazardous Material Handling, Environmental Monitoring, Hazardous Substance Release Reporting, and Environmental Protection Quality Assurance.

\begin{tabular}{|c|c|c|c|}
\hline $\begin{array}{l}\text { 6c) Are these procedures being effectively } \\
\text { implemented in nearby CWC/SWD buildings? } \\
\text { * Verify that sufficient personnel are } \\
\text { trained and available on a round-the-clock } \\
\text { basis to respond to the above actions. } \\
\text { [Coordinate the response and supporting } \\
\text { documentation with lead ORR reviewer for } \\
\text { training]. }\end{array}$ & $\begin{array}{l}\text { K. McDonald } \\
\text { B. Giroir } \\
\text { R. Irwin } \\
\text { J. Winterhaider }\end{array}$ & $\begin{array}{l}\text { Management expressed that current } \\
\text { staffing levels are adequate for } \\
\text { normal operations in existing CWC } \\
\text { facilities plus addition of Phase } \\
V \text { buildings. A11 } 24 X X \text {-series of } \\
\text { buildings are served by same } \\
\text { personnel. CWC can draw on other } \\
\text { SWD staff if workscope requires. } \\
\text { Normal operation/waste movements } \\
\text { into Phase } V \text { buildings are on day- } \\
\text { shift. Off-normal response is by } \\
\text { selected staff "on-call." }\end{array}$ & $X$ \\
\hline
\end{tabular}


CORE REQUIREMENT 8.3: There is an adequate environmental protection organization and program, to include Air Quality, Surface Water, Groundwater, Solid and Hazardous Waste, Hazardous Material Handling, Environmental Monitoring, Hazardous Substance Release Reporting, and Environmental Protection Quality Assurance.

\section{CRITERION 7:}

A11 required permits for construction and operation are possessed and associated requirements are in effect.

\section{APPROACH:}

\begin{tabular}{|c|c|c|c|c|}
\hline \multirow{2}{*}{$\begin{array}{c}\text { SUBJECT/ACTIVITY } \\
\text { REQUIREMENT REFERENCE }\end{array}$} & \multirow{2}{*}{$\begin{array}{l}\text { EVIDENCE EXAMINED/ } \\
\text { PERSONNEL CONTACTED }\end{array}$} & \multirow[t]{2}{*}{ OBSERVATIONS/COMMENTS } & \multicolumn{2}{|c|}{ COMPLY } \\
\hline & & & YES & No \\
\hline $\begin{array}{l}\text { 7) Verify that all required permits for } \\
\text { construction and Phase } V \text { operations (e.g., } \\
\text { air, water, waste, TSD, etc) are possessed } \\
\text { (or on file at SWD) and associated } \\
\text { requirements are ready to be implemented. }\end{array}$ & K. McDonald & $\begin{array}{l}\text { Regulatory documents, including } \\
\text { permits, applications, supporting } \\
\text { studies, (everything except actual } \\
\text { construction) are maintained in } \\
\text { CWC EC manager area. Regulatory } \\
\text { File Index is used as a road map } \\
\text { to facilitate individual document/ } \\
\text { data retrieval. }\end{array}$ & $x$ & \\
\hline $\begin{array}{l}\text { 7a) Verify that all Phase } V \text { environmental } \\
\text { permits and studies are completed; all } \\
\text { permit requirements and actions identified } \\
\text { by environmental reviews, analyses or } \\
\text { studies, have been completed or are } \\
\text { captured within the CWC/SWD compliance } \\
\text { program; no additional permits or studies } \\
\text { are required. }\end{array}$ & $\begin{array}{l}\text { K. McDonald } \\
\text { B. Barnes } \\
\text { L. McDonald }\end{array}$ & Same comment as above. & $x$ & \\
\hline $\begin{array}{l}7 \mathrm{~b}, \text { S/RID 20.1) Was a review of Phase } V \\
\text { project scope made to determine comp] } \\
\text { to National Environmenta] Policy Act } \\
\text { requirements [10 CFR } 1021 \text { et seq]? Do the } \\
\text { CWC/SWD program files contain evidence of } \\
\text { this review? }\end{array}$ & G. Cummins & $\begin{array}{l}\text { NEPA evaluation in environmental } \\
\text { assessment (DOE/EA-0981) developed } \\
\text { by central ES organization, issued } \\
\text { Sept } 1995 \text {. }\end{array}$ & $x$ & \\
\hline
\end{tabular}




\section{PHASE V STORAGE ORR APPRAISAL FORM}

CORE REQUIREMENT 8.3: There is an adequate environmental protection organization and program, to include Air Quality, Surface Water, Groundwater, Solid and Hazardous Waste, Hazardous Material Handling, Environmental Monitoring, Hazardous Substance Release Reporting, and Environmental Protection Quality Assurance.

\begin{tabular}{|c|c|c|c|}
\hline $\begin{array}{l}7 \mathrm{c}, \mathrm{S} / \mathrm{RID} 20.1 \text { ) HaS DOE/RL determined } \\
\text { that Phase } V \text { is covered for NEPA under } \\
\text { pre-existing documentation? } \\
\text { * Is the change to the Interim Safety } \\
\text { Basis noted and accounted for in the NEPA } \\
\text { documentation? } \\
\text { * Is a copy of the DOE NEPA designation } \\
\text { (ROD/FONSI) available in CWC/SWD project } \\
\text { files? } \\
\text { * Was a separate SEPA review made, or } \\
\text { SEPA checklist submitted? [WAC 197-11 \& } \\
352-11]\end{array}$ & $\begin{array}{l}\text { Examined EA/FONSI for } \\
\text { CWC/SWD Phase } V \\
\text { proposed action(s). }\end{array}$ & $\begin{array}{l}\text { A Finding of No Significant Impact } \\
\text { (FONSI) was signed by the DOE/RL } \\
\text { site manager and bound into the EA } \\
\text { document. } \\
\text { The EA/FONSI is maintained in the } \\
\text { Site-wide NEPA characterization } \\
\text { library, by the central ES } \\
\text { organization. }\end{array}$ & $X$ \\
\hline $\begin{array}{l}\text { 7d, S/RID 20.2) Will the Phase V facility } \\
\text { operate as a Resource Conservation and } \\
\text { Recovery (RCRA) treatment/storage/disposal } \\
\text { facility [WAC 173-303-400]? } \\
\text { * If so, is a RCRA Part A permit in } \\
\text { place? } \\
\text { * Has supporting data for the RCRA Part B } \\
\text { permit been submjtted for inclusion in the } \\
\text { averal Hanford RCRA permit? }\end{array}$ & $\begin{array}{l}\text { SWD Strategic Plan \& } \\
\text { Technical Baseline } \\
\text { Document }\end{array}$ & $\begin{array}{l}\text { By customer (DOE) decision, the } \\
\text { Hanford facilities will comply } \\
\text { with all legislated requirements, } \\
\text { including Resource Conservation } \\
\text { and Recovery Act (RCRA) treatment, } \\
\text { storage \& disposal requirements, } \\
\text { as applicable. }\end{array}$ & $X$ \\
\hline
\end{tabular}


PHASE V STORAGE ORR APPRAISAL FORM

CORE REQUIREMENT 8.3: There is an adequate environmental protection organization and program, to include Air Quality, Surface Water, Groundwater, Sol id and Hazardous Waste, Hazardous Material Handling, Environmental Monitoring, Hazardous Substance Release Reporting, and Environmental Protection Quality Assurance.

\begin{tabular}{|c|c|c|c|}
\hline $\begin{array}{l}\text { 7e, S/RID 20.2) Has a Ticense to operate } \\
\text { been granted for Phase } V \text { by the State? } \\
\text { [WAC 246-247-060] } \\
\text { * Have emissions data been estimated and } \\
\text { submitted for inclusion in the next } \\
\text { revision of the Hanford Air Operating } \\
\text { Permit? }\end{array}$ & $\begin{array}{l}\text { B. Giroir } \\
\text { K. McDonald } \\
\text { B. Curn }\end{array}$ & $\begin{array}{l}\text { The Phase facilities were built } \\
\text { as a turn-key project. } \\
\text { Construction was regularly } \\
\text { overseen by State \& Federal } \\
\text { regulators. All proposed } \\
\text { emissions data are included in the } \\
\text { NOC (DOE/RL-95-79). }\end{array}$ & $X$ \\
\hline
\end{tabular}


PHASE V STORAGE ORR APPRAISAL FORM

CORE REQUIREMENT 8.3: There is an adequate environmental protection organization and program, to include Air Quality, Surface Water, Groundwater, Sol id and Hazardous Waste, Hazardous Material Handling, Environmental Monitoring, Hazardous Substance Release Reporting, and Environmental Protection Quality Assurance.

CRITERION-8:

A1I environmental reviews and studies have been performed.

\section{APPROACH:}

\begin{tabular}{|c|c|c|c|c|}
\hline \multirow{2}{*}{$\begin{array}{c}\text { SUBJECT/ACTIVITY } \\
\text { REQUIREMENT REFERENCE }\end{array}$} & \multirow{2}{*}{$\begin{array}{l}\text { EVIDENCE EXAMINED/ } \\
\text { PERSONNEL CONTACTED }\end{array}$} & \multirow[t]{2}{*}{ OBSERVATIONS/COMMENTS } & \multicolumn{2}{|c|}{ COMPLY } \\
\hline & & & YES & No \\
\hline $\begin{array}{l}\text { 8) Verify that all environmental reviews } \\
\text { and studies (required per CM-6-2 \& CM-7-5) } \\
\text { have been performed (e.g., NEPA, BARCT, } \\
\text { T-RACT, ALARARCT, etc.) }\end{array}$ & & $\begin{array}{l}\text { Environmental reviews and studies } \\
\text { are part of the project design \& } \\
\text { management requirements (CM-6-2). } \\
\text { Environmental compliance is } \\
\text { assured by multiple reviews/ } \\
\text { studies by both the CWC facility } \\
\text { and the central ES organization. } \\
\text { Comments and quality changes to } \\
\text { the facility design/implementation } \\
\text { requirements are maintained in the } \\
\text { project construction file for the } \\
\text { operating life of the facility. } \\
\text { Verification of the construction } \\
\text { records was not made, due to time } \\
\text { limitations. }\end{array}$ & $x$ & \\
\hline
\end{tabular}




\section{PHASE V STORAGE ORR APPRAISAL FORM}

CORE REQUIREMENT 8.3: There is an adequate environmental protection organization and program, to include Air Quality, Surface Water, Groundwater, Solid and Hazardous Haste, Hazardous Material Handling, Environmental Monitoring, Hazardous Substance Release Reporting, and Environmental Protection Quality Assurance.

\begin{tabular}{|c|c|c|c|c|}
\hline $\begin{array}{l}\text { 8a) Coordinate verification with ORR } \\
\text { safety reviewer, to ensure that no } \\
\text { conflict exists between the environmental } \\
\text { boundary of operation, defined in the } \\
\text { reviews, and the ISB document. }\end{array}$ & $\begin{array}{l}\text { K. McDonald } \\
\text { B. Barnes } \\
\text { L. Olsen }\end{array}$ & $\begin{array}{l}\text { The ISB has been and S/RID current } \\
\text { being reviewed for possible } \\
\text { conflicts and effectiveness. } \\
\text { Review of the S/RID is covered by } \\
\text { Observation } 0.8 .3 .1 .1 \text {. } \\
\text { See comments also from ORR member } \\
\text { on Safety. }\end{array}$ & TBD & \\
\hline $\begin{array}{l}8 \mathrm{~b}, \text { S/RID 20.2) Were any waivers to } \\
\text { existing Hanford operating permits } \\
\text { required as a result of the proposed } \\
\text { operational scope of Phase V? } \\
\text { * If so, were any compliance plans } \\
\text { developed as a result of Phase V review by } \\
\text { technical authorities? [WAC 173-480] }\end{array}$ & $\begin{array}{l}\text { K. McDonald } \\
\text { B. Barnes } \\
\text { L. Olsen }\end{array}$ & $\begin{array}{l}\text { No waivers apply to Phase } V \text {. } \\
\text { No recovery plans apply. }\end{array}$ & $\mathrm{n} / \mathrm{a}$ & \\
\hline
\end{tabular}




\section{PHASE V STORAGE ORR APPRAISAL FORM}

CORE REQUIREMENT 8.3: There is an adequate environmental protection organization and program, to include Air Quality, Surface Water, Groundwater, Solid and Hazardous Waste, Hazardous Material Handling, Environmental Monitoring, Hazardous Substance Release Reporting, and Environmental Protection Quality Assurance.

\section{CRITERION $9:$}

A system is in place to provide estimates of quantities and assess integrated impacts of releases of hazardous material on personnel, the public and the environment.

\section{APPROACH:}

\begin{tabular}{|c|c|c|c|c|}
\hline \multirow{2}{*}{$\begin{array}{l}\text { SUBJECT/ACTIVITY } \\
\text { REQUIREMENT REFERENCE }\end{array}$} & \multirow{2}{*}{$\begin{array}{l}\text { EVIDENCE EXAMINED/ } \\
\text { PERSONNEL CONTACTED }\end{array}$} & \multirow[t]{2}{*}{ OBSERVATIONS/COMMENTS } & \multicolumn{2}{|c|}{ COMPLY } \\
\hline & & & YES & NO \\
\hline $\begin{array}{l}\text { 9) Verify that inventory control } \\
\text { procedures are in place for monitoring and } \\
\text { limiting the type and quantity of toxic } \\
\text { and chemical materials purchased by CWC. }\end{array}$ & $\begin{array}{l}\text { K. McDonald } \\
\text { B. Barnes } \\
\text { L. 01sen } \\
\text { R. Irwin } \\
\text { Examined POPs Index } \\
\text { Examined selected POPS } \\
\text { from HLAN } \\
\text { ISB }\end{array}$ & $\begin{array}{l}\text { Each facility, including Phase } V \\
\text { buildings have a radioactive } \\
\text { inventory control Timit(s) as } \\
\text { specified in the ISB. Only the } \\
616 \text { building has explicit controls } \\
\text { for handling of hazardous, non- } \\
\text { radioactive materials. The SW } \\
\text { Acceptance criteria (EP-0063-4) } \\
\text { has the primary controls for } \\
\text { incoming waste packaging. These } \\
\text { are administratively controlled as } \\
\text { if separate facilities. }\end{array}$ & $x$ & \\
\hline $\begin{array}{l}\text { 9a) Verify that procedures are in } \mathrm{place} \\
\text { for Phase } v \text { to prevent the release of } \\
\text { toxic and chemical materials to the } \\
\text { environment. } \\
\text { * Verify training and implementation at } \\
\text { other CWC facilities. }\end{array}$ & $\begin{array}{l}\text { Same as above, plus } \\
\text { Drill participants }\end{array}$ & $\begin{array}{l}\text { Drill participant awareness of } \\
\text { non-radioactive hazards and } \\
\text { appropriate off-normal responses } \\
\text { judged inadequate. } \\
\text { A finding, F.8.3.5.1, is submitted } \\
\text { to improve this issue. }\end{array}$ & & $x$ \\
\hline
\end{tabular}


PHASE V STORAGE ORR APPRAISAL FORM

CORE REQUIREMENT 8.3: There is an adequate environmental protection organization and program, to include Air Quality, Surface Water, Groundwater, Solid and Hazardous Waste, Hazardous Material Handling, Environmental Monitoring, Hazardous Substance Release Reporting, and Environmental Protection Quality Assurance.

\begin{tabular}{|c|c|c|c|c|}
\hline $\begin{array}{l}9 \mathrm{~b}, \text { S/RID } 20.3 \text { ) Is a procedure in place } \\
\text { to track and close deficiencies identified } \\
\text { by inspections at Phase } V \text { ? } \\
\text { * Are sufficient numbers of CWC/SWD } \\
\text { personnel trained in order to implement at } \\
\text { Phase } V \text { ? } \\
\text { * Are similar procedure being effectively } \\
\text { implemented at other CWC/SWD facilities? } \\
\text { * [Coordinate answers with ORR reviewer } \\
\text { for Core Requirement } 6 . \text { ] }\end{array}$ & $\begin{array}{l}\text { K. McDonald } \\
\text { B. Barnes } \\
\text { L. Olsen } \\
\text { M. McChesney } \\
\text { Examined POPs Index } \\
\text { S/RIDs } \\
\text { Training files }\end{array}$ & $\begin{array}{l}\text { The FEB did not issue any findings } \\
\text { against the environmental training } \\
\text { part in this area of ORR. The CWC } \\
\text { EC maintains its own action list } \\
\text { for low-impact deficiencies } \\
\text { (housekeeping, etc). Compliance } \\
\text { deficiencies are put on the } \\
\text { Hanford Action Tracking System } \\
\text { by the person who identifies the } \\
\text { item/issue. } \\
\text { Threshold action limits are } \\
\text { determined outside the CWC. This } \\
\text { requirement is a partial basis for } \\
\text { finding F.8.3.5.1, due to critique } \\
\text { of the drill. }\end{array}$ & $x$ & TBD \\
\hline $\begin{array}{l}\text { 9c, S/RID 20.6) Will Phase V operations } \\
\text { require support from on-site laboratory to } \\
\text { meet waste composition/identification/ } \\
\text { analysis/designation, labeling, } \\
\text { segregation, and storage requirements? } \\
\text { * If so, is an interface procedure in } \\
\text { place to define how samples will be taken, } \\
\text { packaged, transported, custody controlled, } \\
\text { and disposed of after analysis? } \\
\text { [40 CFR } 372.30]\end{array}$ & $\begin{array}{l}\text { K. McDonald } \\
\text { B. Barnes } \\
\text { B. Giroir } \\
\text { Examine S/RIDs } \\
\text { Examine POPs Index }\end{array}$ & $\begin{array}{l}\text { Phase } V \text { will not generate samples } \\
\text { for the laboratory. Selected } \\
\text { verification of container waste } \\
\text { contents/designation is done } \\
\text { before receipt at Phase V. } \\
\text { Verification of Sampling by the } \\
\text { Waste Generators at other SWD } \\
\text { facilities was not done due to } \\
\text { insufficient time. }\end{array}$ & $\mathrm{n} / \mathrm{a}$ & TBD \\
\hline
\end{tabular}


CORE REQUIREMENT 8.3: There is an adequate environmental protection organization and program, to include Air Quality, Surface Water, Groundwater, Sol id and Hazardous Waste, Hazardous Material Handling, Environmental Monitoring, Hazardous Substance Release Reporting, and Environmental Protection Quality Assurance.

\section{CRITERION 10}

Hazardous substances are monitored, sampled and analyzed in order to support notifications and reporting to authorities.

\section{APPROACH:}

\begin{tabular}{|c|c|c|c|c|}
\hline \multirow{2}{*}{$\begin{array}{c}\text { SUBJECT/ACTIVITY } \\
\text { REQUIREMENT REFERENCE }\end{array}$} & \multirow{2}{*}{$\begin{array}{l}\text { EVIDENCE EXAMINED/ } \\
\text { PERSONNEL CONTACTED }\end{array}$} & \multirow[t]{2}{*}{ OBSERVATIONS/COMMENTS } & \multicolumn{2}{|c|}{ COMPLY } \\
\hline & & & YES & NO \\
\hline $\begin{array}{l}\text { 10) Verify that procedures for operating } \\
\text { monitoring, sampling and } 1 \text { aboratory } \\
\text { analysis equipment to support Phase } V \text { are } \\
\text { in place. }\end{array}$ & $n / a$ & $\begin{array}{l}\text { Monitoring and sampling are not } \\
\text { performed inside of Phase } V \text {. } \\
\text { Wastes must meet characterization/ } \\
\text { labeling requirements before being } \\
\text { accepted at CWC. }\end{array}$ & $n / a$ & \\
\hline $\begin{array}{l}\text { 10a) If these activities will be done by } \\
\text { CWC/SWD personnel, verify training (or } \\
\text { certification) is current. } \\
\text { * If activities will be done by non-CWC } \\
\text { personnel, verify the administrative } \\
\text { program for training is being implemented. } \\
\text { * If activities will be done by non-PHMC } \\
\text { laboratory/contractor, verify the source } \\
\text { quality program has been reviewed by } \\
\text { appropriate oversight organization. }\end{array}$ & $n / a$ & See above comment. & $n / a$ & \\
\hline
\end{tabular}




\section{PHASE V STORAGE ORR APPRAISAL FORM}

CORE REQUIREMENT 8.3: There is an adequate environmental protection organization and program, to include Air Quality, Surface Water, Groundwater, Solid and Hazardous Waste, Hazardous Material Handling, Environmental Monitoring, Hazardous Substance Release Reporting, and Environmental Protection Quality Assurance.

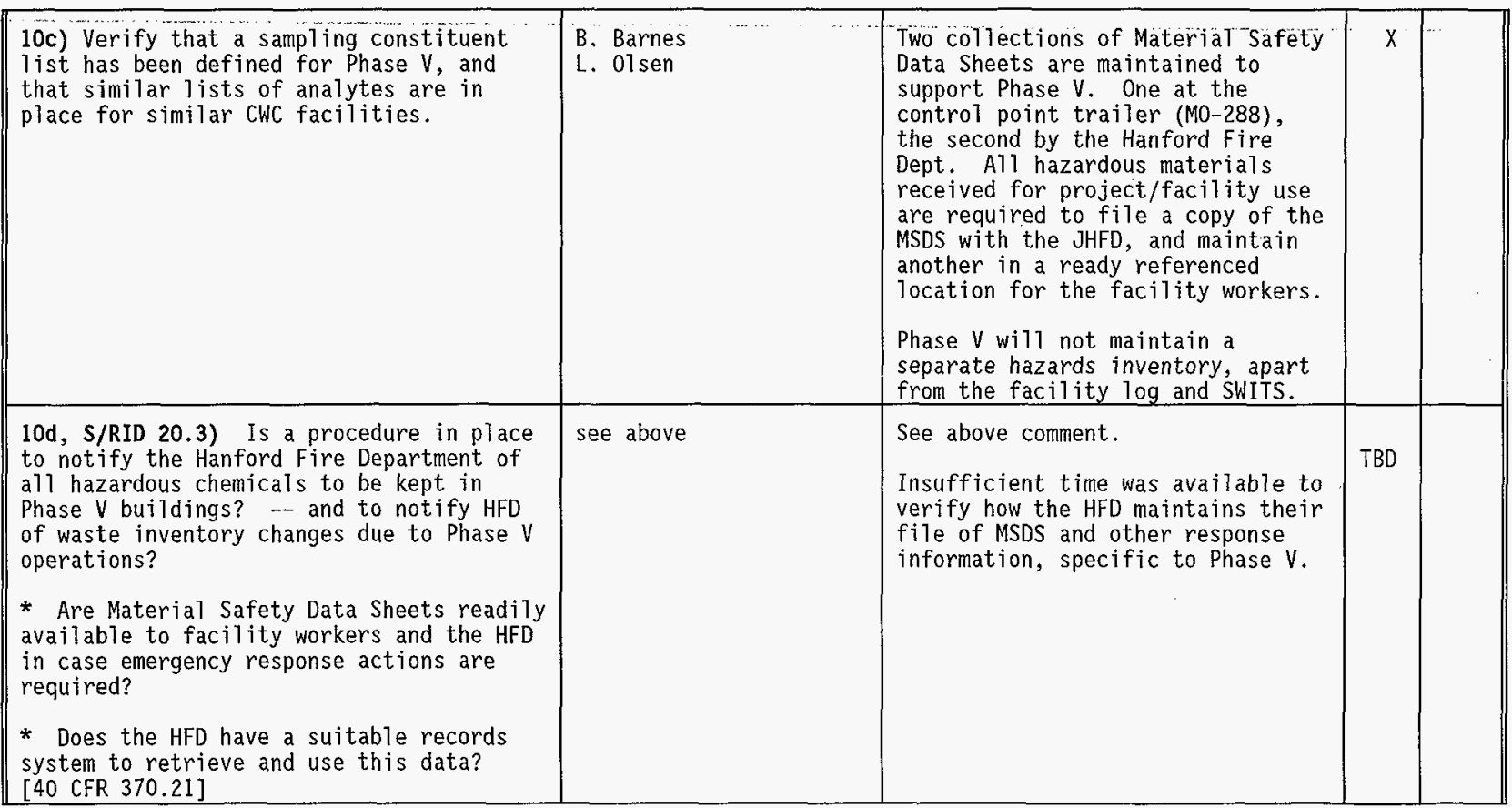


PHASE V.STORAGE ORR APPRAISAL FORM

CORE REQUIREMENT 8.3: There is an adequate environmental protection organization and program, to include Air Quality, Surface Water, Groundwater, Solid and Hazardous Waste, Hazardous Material Handling, Environmental Monitoring, Hazardous Substance Release Reporting, and Environmental Protection Quality Assurance.

\begin{tabular}{|c|c|c|c|c|}
\hline $\begin{array}{l}10 \mathrm{e} \text { S/RID 20.3) Are sufficient numbers } \\
\text { of CWC workers trained to use the above } \\
\text { notification procedures? } \\
\text { * Are the above procedures being } \\
\text { effectively implemented in other CWC/SWD } \\
\text { buildings? }\end{array}$ & $\begin{array}{l}\text { Dri17 Participants \& } \\
\text { Observers }\end{array}$ & $\begin{array}{l}\text { Drilt responsibility was judged } \\
\text { unsatisfactory in this area. See } \\
\text { finding F.8.3.5.1 }\end{array}$ & & $x$ \\
\hline $\begin{array}{l}\text { 10f, S/RID 20.6) Is a procedure in place } \\
\text { to provide the following information in } \\
\text { annual report (s): Emission inventory, } \\
\text { monitoring, investigation by oversight } \\
\text { groups, demonstration/testing for } \\
\text { regulatory compliance, air flow rate(s), } \\
\text { average emission rate \& emission logs, } \\
\text { shutdown notifications, decontamination/ } \\
\text { decommissioning/closure plans? } \\
\text { [WAC } 246-247-80 \text { and } 40 \text { CFR } 61 \text { parts H \& I] }\end{array}$ & $\begin{array}{l}\text { K. McDonald } \\
\text { B. Barnes } \\
\text { B. Curn } \\
\text { L. Olsen } \\
\text { J. Skolrud } \\
\text { J. Winterhalder }\end{array}$ & $\begin{array}{l}\text { Desk instructions and a database } \\
\text { user guide are available to } \\
\text { control data retrieval for } \\
\text { reports. Specific data for Phase } \\
V \text { are in the NOC (DOE/RL-95-79). } \\
\text { Operational data have not been } \\
\text { generated, yet. Data are copied } \\
\text { to originator for verification/ } \\
\text { validation prior to issuing the } \\
\text { annual report(s). }\end{array}$ & $X$ & $\mathrm{n} / \mathrm{a}$ \\
\hline
\end{tabular}


PHASE V STORAGE ORR APPRAISAL FORM

CORE REQUIREMENT 8.3: There is an adequate environmental protection organization and program, to include Air Quality, Surface Water, Groundwater, Sol id and Hazardous Waste, Hazardous Material Handling, Environmental Monitoring, Hazardous Substance Release Reporting, and Environmental Protection Quality Assurance.

\section{CRITERION-11:}

Environmental Sampling Programs are conducted to establish a baseline for radioactivity in the environment near Phase $V$ buildings, and establish a baseline for comparison in the event of excursion.

\section{APPROACH:}

\begin{tabular}{|c|c|c|c|c|}
\hline \multirow{2}{*}{$\begin{array}{c}\text { SUBJECT/ACTIVITY } \\
\text { REQUIREMENT REFERENCE }\end{array}$} & \multirow{2}{*}{$\begin{array}{l}\text { EVIDENCE EXAMINED/ } \\
\text { PERSONNEL CONTACTED }\end{array}$} & \multirow[t]{2}{*}{ OBSERVATIONS/COMMENTS } & \multicolumn{2}{|c|}{ COMPLY } \\
\hline & & & YES & NO \\
\hline $\begin{array}{l}\text { 11) Review procedures and observe } \\
\text { operations of equipment used for sampling, } \\
\text { monitoring, and analyzing hazardous } \\
\text { substances. [See Criterion 13, also.] }\end{array}$ & $n / a$ & $\begin{array}{l}\text { Insufficient time was available to } \\
\text { verify this issue, beyond what is } \\
\text { provided in the prior comments. }\end{array}$ & & TBD \\
\hline $\begin{array}{l}\text { Ila, S/RID 20.2) Were any pre-operational } \\
\text { tests conducted to determine effectiveness } \\
\text { of the compliance monitoring instruments? } \\
\text { * Was Phase V required to perform a } \\
\text { compliance demonstration test to verify } \\
\text { meeting BARCT and ALARACT goals? } \\
\text { * Has a similar performance demonstration } \\
\text { been performed for any nearby CWC/SWD } \\
\text { facility? } \\
\text { * Was opportunity to observe these tests } \\
\text { offered to the State regulators [WAC } 246- \\
247 \text { et seq]? }\end{array}$ & $\begin{array}{l}\text { B. Barnes } \\
\text { B. Giroir } \\
\text { R. Irwin }\end{array}$ & $\begin{array}{l}\text { Insufficient time was available to } \\
\text { verify this issue beyond the Phase } \\
V \text { buildings. } \\
\text { The State regulators had a } \\
\text { representative on sit for the } \\
\text { majority of the construction of } \\
\text { Phase } V \text { facilities. They were } \\
\text { aware of, but chose not to attend } \\
\text { the ATP/OTP activity. }\end{array}$ & $n / a$ & \\
\hline
\end{tabular}


CORE REQUIREMENT 8.3: There is an adequate environmental protection organization and program, to include Air Quality, Surface Water, Groundwater, Solid and Hazardous Waste, Hazardous Material Handi ing, Environmental Monitoring, Hazardous Substance Release Reporting, and Environmental Protection Quality Assurance.

\begin{tabular}{|c|c|c|c|c|}
\hline $\begin{array}{l}\text { 11b) Verify that the Phase } V \text { facility has } \\
\text { sufficient staff trained and able: to } \\
\text { characterize wastes, to determine if } \\
\text { releases are occurring, to collect data } \\
\text { for notification and reporting, in } \\
\text { compliance with Federal and State } \\
\text { requirements. }\end{array}$ & K. McDonald & $\begin{array}{l}\text { See prior comments on training and } \\
\text { staff sufficiency. } \\
\text { This activity is outside the scope } \\
\text { of Phase } V \text { operations. See prior } \\
\text { comments. }\end{array}$ & $\begin{array}{r}X \\
n / a\end{array}$ & \\
\hline
\end{tabular}




\section{PHASE V STORAGE ORR APPRAISAL FORM}

CORE REQUIREMENT 8.3: There is an adequate environmental protection organization and program, to include Air Quality, Surface Water, Groundwater, Solid and Hazardous Waste, Hazardous Material Handling, Environmental Monitoring, Hazardous Substance Release Reporting, and Environmental Protection Quality Assurance.

\section{CRIFERION 12:}

Equipment and resources for sampling and analysis of environmental media are in place to assure that significant spills/releases from Phase $V$ storage are not occurring, and radioactive or hazardous materials are not accumulating in the environment.

\section{APPROACH:}

\begin{tabular}{|c|c|c|c|c|}
\hline \multirow{2}{*}{$\begin{array}{c}\text { SUBJECT/ACTIVITY } \\
\text { REQUIREMENT REFERENCE }\end{array}$} & \multirow{2}{*}{$\begin{array}{l}\text { EVIDENCE EXAMINED/ } \\
\text { PERSONNEL CONTACTED }\end{array}$} & \multirow[t]{2}{*}{ OBSERVATIONS/COMMENTS } & \multicolumn{2}{|c|}{ COMPLY } \\
\hline & & & YES & NO \\
\hline $\begin{array}{l}\text { 12) Verify that the pre-operational } \\
\text { baseline assessment of environmental } \\
\text { radioactivity levels has been reviewed to } \\
\text { ensure that changes in radioactivity } \\
\text { levels, significant per regulatory basis, } \\
\text { can be determined and measured. Verify the } \\
\text { data can be analyzed in a timely manner. }\end{array}$ & $\mathrm{n} / \mathrm{a}$ & $\begin{array}{l}\text { This is a standard requirement } \\
\text { before actual construction can } \\
\text { start, per project management } \\
\text { manual (CM- } 6-1 \text { ) Insufficient } \\
\text { time was available to verify data } \\
\text { to confirm the item. } \\
\text { The evaluation of radioactivity } \\
\text { levels by the CWC/EC staff } \\
\text { represents a potential process } \\
\text { improvement issue. }\end{array}$ & . & \\
\hline
\end{tabular}


CORE REQUIREMENT 8.3: There is an adequate environmental protection organization and program, to include Air Quality, Surface Water, Groundwater, Solid and Hazardous Waste, Hazardous Material Handling, Environmental Monitoring, Hazardous Substance Release Reporting, and Environmental Protection Quality Assurance.

\begin{tabular}{|c|c|c|c|c|}
\hline $\begin{array}{l}12 a, \text { S/RID 20.3) Is a procedure in place } \\
\text { to inspect Phase } V \text { compliance monitoring } \\
\text { equipment, which would detect or prevent } \\
\text { release of contamination to the } \\
\text { environment? [WAC 173-303-320] } \\
\text { * Are sufficient number of personnel } \\
\text { trained in use of the procedure(s)? } \\
\text { * Are similar procedures effectively } \\
\text { implemented at other CWC/SWD facilities? }\end{array}$ & $\begin{array}{l}\text { B. Barnes } \\
\text { L. Olsen }\end{array}$ & $\begin{array}{l}\text { This is outside the scope of the } \\
\text { CWC Environmental program. } \\
\text { Only standard instrumentation is } \\
\text { the air samplers, which are a } \\
\text { maintenance worker responsibility. } \\
\text { The EC facility inspections focus } \\
\text { mainly on facility/waste container } \\
\text { integrity. }\end{array}$ & (1) & \\
\hline $\begin{array}{l}\text { 12a) Verify that CWC/SWD has supplied data } \\
\text { to the most recent Hanford Site-wide } \\
\text { Environmental Report. } \\
\text { * Verify that CWC Environmental } \\
\text { Compliance reviewed the data for } \\
\text { applicability/trends and suitability of } \\
\text { administrative controls at Phase V. }\end{array}$ & $\begin{array}{l}\text { Hanford Site annua? } \\
\text { Environmental Report } \\
\text { (1995) }\end{array}$ & $\begin{array}{l}\text { SWD } / \text { CWC contaminants tracked as } \\
\text { part of the overall } 200 \text {-West Area } \\
\text { summary in annual report. No non- } \\
\text { compliant issues identified. }\end{array}$ & $X$ & \\
\hline $\begin{array}{l}12 \mathrm{~b}, \text { S/RID } 20.6 \text { ) Is a procedure in place } \\
\text { to respond to spills and other unplanned } \\
\text { releases from Phase V? } \\
\text { * Are sufficient numbers of CWC personnel } \\
\text { trained to effectively implement the } \\
\text { procedure? } \\
\text { * Are similar procedure being implemented } \\
\text { at other CWC/SWD facilities? }\end{array}$ & $\begin{array}{l}\text { Drill participants \& } \\
\text { observers }\end{array}$ & $\begin{array}{l}\text { Phase } V \text { will use the same response } \\
\text { procedures as the other dry } \\
\text { storage buildings. } \\
\text { Program requirements in current } \\
\text { documents are judged adequate, but } \\
\text { response actions for non- } \\
\text { radioactive hazards judged } \\
\text { unsatisfactory. See Finding } \\
\text { F.8.3.5.1. }\end{array}$ & $X$ & $x$ \\
\hline
\end{tabular}




\section{PHASE V STORAGE ORR APPRAISAL FORM}

CORE REQUIREMENT 8.3: There is an adequate environmental protection organization and program, to include Air Quality, Surface Water, Groundwater, Solid and Hazardous Waste, Hazardous Material Handling, Environmental Monitoring, Hazardous Substance Release Reporting, and Environmental Protection Quality Assurance.

\section{CRITERION 13:}

Phase V Sample and Analysis procedures are in place.

\section{APPROACH:}

\begin{tabular}{|c|c|c|c|c|}
\hline \multirow{2}{*}{$\begin{array}{l}\text { SUBJECT/ACTIVITY } \\
\text { REQUIREMENT REFERENCE }\end{array}$} & \multirow{2}{*}{$\begin{array}{l}\text { EVIDENCE EXAMINED/ } \\
\text { PERSONNEL CONTACTED }\end{array}$} & \multirow[t]{2}{*}{ OBSERVATIONS/COMMENTS } & \multicolumn{2}{|c|}{ COMPLY } \\
\hline & & & YES & No \\
\hline $\begin{array}{l}\text { 13, S/RID 20.3) Are procedures in place } \\
\text { to evaluate container contents as mixtures } \\
\text { of hazardous, radioactive, or extremely } \\
\text { hazardous/dangerous materials (wastes), } \\
\text { which are to be received into the Phase } V \\
\text { buildings, and apply the applicable } \\
\text { management controls? } \\
\text { * Are suitable numbers of personnel } \\
\text { trained in use of these procedures, and } \\
\text { effectively implementing them in other } \\
\text { CWC/SWD buildings? }\end{array}$ & $\begin{array}{l}\text { B. Barnes } \\
\text { L. O1sen } \\
\text { Examine S/RIDS } \\
\text { EC manual (CM-7-5) } \\
\text { Training records file }\end{array}$ & $\begin{array}{l}\text { Insufficient time was available to } \\
\text { verify all details of this } \\
\text { requirement. } \\
\text { Sampling and designation is done. } \\
\text { within CWC by the Generator } \\
\text { Services organization. The same } \\
\text { procedures in use for all CWC } \\
\text { facilities. } \\
\text { Waste containers should be } \\
\text { characterized prior to receipt } \\
\text { into the Phase } V \text { facilities. }\end{array}$ & $\mathrm{TBD}$ & TBD \\
\hline $\begin{array}{l}\text { 13) Review procedures and verify training/ } \\
\text { operations of equipment used for sampling, } \\
\text { monitoring, and analyzing hazardous } \\
\text { substances in incoming and stored Phase V } \\
\text { containers. [See Criterion 11.] }\end{array}$ & $n / a$ & $\begin{array}{l}\text { Insufficient time was available to } \\
\text { verify. }\end{array}$ & & TBD \\
\hline
\end{tabular}


PHASE V STORAGE ORR APPRAISAL FORM

CORE REQUIREMENT 8.3: There is an adequate environmental protection organization and program, to include Air Quality, Surface Water, Groundwater, Solid and Hazardous Waste, Hazardous Material Handling, Environmental Monitoring, Hazardous Substance Release Reporting, and Environmental Protection Quality Assurance.

13a) If analysis of samples is to be done by non-CWC personnel, verify per approach

B. Barnes

Sampling/analysis is outside the scope of Phase $V$ operation. 


\section{PHASE V STORAGE ORR APPRAISAL FORM}

CORE REQUIREMENT 8.3: There is an adequate environmental protection organization and program, to include Air Quality, Surface Water, Groundwater, Solid and Hazardous Waste, Hazardous Material Handling, Environmental Monitoring, Hazardous Substance Release Reporting, and Environmental Protection Quality Assurance.

\section{CRITERION 14:}

Personnel in CWC Environmental Compliance have the needed knowledge, skills and abilities to conduct the program.

\section{APPROACH:}

\begin{tabular}{|c|c|c|c|c|}
\hline \multirow{2}{*}{$\begin{array}{l}\text { SUBJECT/ACTIVITY } \\
\text { REQUIREMENT REFERENCE }\end{array}$} & \multirow{2}{*}{$\begin{array}{l}\text { EVIDENCE EXAMINED/ } \\
\text { PERSONNEL CONTACTED }\end{array}$} & \multirow[t]{2}{*}{ OBSERVAT IONS/COMMENTS } & \multicolumn{2}{|c|}{ COMPLY } \\
\hline & & & YES & NO \\
\hline $\begin{array}{l}\text { 14) Interview random CWC personnel who } \\
\text { wil1 support Phase } V \text { operations. Verify } \\
\text { that sufficient training or certification } \\
\text { has been completed to provide coverage for } \\
\text { all required actions in the facility, plus } \\
\text { at least one backup person. }\end{array}$ & $\begin{array}{l}\text { K. McDonald } \\
\text { B. Barnes } \\
\text { L. Olsen } \\
\text { S. Addelman } \\
\text { M. McChesney }\end{array}$ & $\begin{array}{l}\text { The ETJAs have been completed for } \\
\text { CWC/EC staff. Training records } \\
\text { are being maintained, annual } \\
\text { retraining is scheduled. } \\
\text { Interviews with staff demonstrate } \\
\text { good understanding and competency } \\
\text { to operate. } \\
\text { Level of knowledge is al so covered } \\
\text { by ORR Core Requirement } 3 \text {. }\end{array}$ & $x$ & \\
\hline $\begin{array}{l}\text { 14a) Verify that a job skills analysis or } \\
\text { similar evaluation has been made for all } \\
\text { key personnel assigned to support Phase } V \text {. } \\
\text { Coordinate verification of criterion } 14 \text {, } \\
\text { with ORR reviewer(s) for Core Requirements } \\
2 \& 3 \text {. }\end{array}$ & $n / a$ & $\begin{array}{l}\text { These activities outside the scope } \\
\text { of CWC/EC involvement to support } \\
\text { Phase } V \text {. See comments on approach } \\
13 \text {, above. } \\
\text { Waste containers must be (sampled) } \\
\text { characterized/designated prior to } \\
\text { receipt into Phase } V \text { buildings. }\end{array}$ & $n / a$ & \\
\hline
\end{tabular}




\section{PHASE V STORAGE ORR APPRAISAL FORM}

CORE REQUIREMENT 8.3: There is an adequate environmental protection organization and program, to include Air Quality, Surface Water, Groundwater, Solid and Hazardous Waste, Hazardous Material Handling, Environmental Monitoring, Hazardous Substance Release Reporting, and Environmental Protection Quality Assurance.

\section{CRITERION 15:}

Phase V storage impact has been assessed by independent monitoring groups and appropriate actions have been made.

\section{APPROACH:}

\begin{tabular}{|c|c|c|c|c|}
\hline \multirow{2}{*}{$\begin{array}{c}\text { SUBJECT/ACTIVITY } \\
\text { REQUIREMENT REFERENCE }\end{array}$} & \multirow{2}{*}{$\begin{array}{l}\text { EVIDENCE EXAMINED/ } \\
\text { PERSONNEL CONTACTED }\end{array}$} & \multirow[t]{2}{*}{ OBSERVATIONS/COMMENTS } & \multicolumn{2}{|c|}{ COMPLY } \\
\hline & & & YES & No \\
\hline $\begin{array}{l}\text { 15) Verify that corrective actions } \\
\text { identified by the Facility Evaluation } \\
\text { Board and/or other external oversight } \\
\text { groups have been closed or suitably } \\
\text { dispositioned. }\end{array}$ & $\begin{array}{l}\text { Facility Evaluation } \\
\text { Board Report, from } F E B \\
\text { evaluation during Dec } \\
9-20,1995 .\end{array}$ & $\begin{array}{l}\text { No environmental program } \\
\text { deficiencies identified by FEB } \\
\text { team. }\end{array}$ & $x$ & \\
\hline $\begin{array}{l}\text { 15a) Verify that all pre-start items from } \\
\text { environmental compliance perspective at } \\
\text { the facility have been dispositioned. }\end{array}$ & $\begin{array}{l}\text { Hanford Action Tracking } \\
\text { System }\end{array}$ & $\begin{array}{l}\text { CWC/EC has no outstanding items on } \\
\text { HATS for Phase } V \text {. } \\
\text { A pre-acceptance action based on } \\
\text { the facility self assessment has } \\
\text { been generated and is referenced } \\
\text { in observation } 0.8 .3 .2 .1\end{array}$ & $\mathrm{TBD}$ & \\
\hline
\end{tabular}




\section{PHASE V STORAGE ORR APPRAISAL FORM}

CORE REQUIREMENT 8.3: There is an adequate environmenta1 protection organization and program, to include Air Quality, Surface Water, Groundwater, Solid and Hazardous Waste, Hazardous Material Handling, Environmental Monitoring, Hazardous Substance Release Reporting, and Environmental Protection Quality Assurance.

\section{CRITERION 16:}

Intra-building waste movements are controlled.

\section{APPROACH.}

\begin{tabular}{|c|c|c|c|c|}
\hline \multirow{2}{*}{$\begin{array}{c}\text { SUBJECT/ACTIVITY } \\
\text { REQUIREMENT REFERENCE }\end{array}$} & \multirow{2}{*}{$\begin{array}{l}\text { EVIDENCE EXAMINED/ } \\
\text { PERSONNEL CONTACTED }\end{array}$} & \multirow[t]{2}{*}{ OBSERVATIONS/COMMENTS } & \multicolumn{2}{|c|}{ COMPLY } \\
\hline & & & YES & NO \\
\hline $\begin{array}{l}\text { 16) Verify administrative controls for } \\
\text { intra-building waste movements are issued } \\
\text { and applicable to Phase } V \text { implementation. }\end{array}$ & $\begin{array}{l}\text { B. Barnes } \\
\text { L. Olsen } \\
\text { K. McDonald } \\
\text { POPs Index }\end{array}$ & $\begin{array}{l}\text { CWC/EC routinely reviews all work } \\
\text { packages, for large quantity } \\
\text { movements of waste. EC does not } \\
\text { review small quantities, except at } \\
\text { request of cog engineer/manager. }\end{array}$ & $x$ & \\
\hline $\begin{array}{l}\text { 16a) Verify environmental requirements, } \\
\text { waste packaging requirements, and safety } \\
\text { basis (ISB) requirements for Phase } V \text { are } \\
\text { incorporated in controls for intra- } \\
\text { building waste movements. }\end{array}$ & $\begin{array}{l}\text { Examine POPS } \\
\text { ISB } \\
\text { WAS sections } \\
\text { CM- } 7-5\end{array}$ & $\begin{array}{l}\text { Specific procedures not used only } \\
\text { to control intra-building waste } \\
\text { movement. } \\
\text { This issue is a potential for } \\
\text { process improvement and is } \\
\text { submitted as an observation. }\end{array}$ & TBD & \\
\hline $\begin{array}{l}\text { 16b, S/RID 20.2) Does Phase V operational } \\
\text { scope include use of any buried piping to } \\
\text { transport, store or treat liquid (either } \\
\text { hazardous, radioactive, mixed or non- } \\
\text { hazardous) wastes? } \\
\text { * If so, is monitoring capability readily } \\
\text { available to determine if leaks can impact } \\
\text { the groundwater? }\end{array}$ & $n / a$ & $\begin{array}{l}\text { Phase } V \text { has no buried piping. } \\
\text { CWC has no known piping for waste } \\
\text { transmission, treatment or } \\
\text { storage. } \\
\text { The TRUSAF has some short run } \\
\text { underground piping, which was not } \\
\text { assessed during this ORR. }\end{array}$ & $n / a$ & \\
\hline
\end{tabular}


PHASE V STORAGE ORR APPRAISAL FORM

CORE REQUIREMENT 8.3: There is an adequate environmental protection organization and program, to include Air Quality, Surface Water, Groundwater, Solid and Hazardous Waste, Hazardous Material Handling, Environmental Monitoring, Hazardous Substance Release Reporting, and Environmental Protection Quality Assurance.

\begin{tabular}{|l|l|l|l|l|}
\hline $\begin{array}{l}\text { 16c) Verify these or similar controls are } \\
\text { being effectively implemented at other } \\
\text { CWC/SWD facilities. }\end{array}$ & n/a & $\begin{array}{l}\text { Inadequate time was available to } \\
\text { verify this issue. }\end{array}$ \\
\hline
\end{tabular}




\section{CORE REQUIREMENT: $\quad 8.4$}

\section{PHASE V STORAGE ORR APPRAISAL FORM}

There is an adequate fire protection program.

Criteria:

1. The Hanford Fire Department is cognizant of CWC's needs and have taken appropriate actions to meet.

2. Administrative procedures are established to control specific fire hazards.

3. A11 facility fire hazards are identified and evaluated on a continuing basis. A Fire Hazard Analysis is documented and complete.

4. Requirements of NFPA and Life Safety Code are specified, implemented, and maintained.

5. Fire protection systems and equipment are available as specified in fire protection program documents.

6. A pre-fire plan is in place and it reflects the current conditions in the facility.

7. A qualified cognizant individual is identified as the single point of contact for CWC's fire systems and fire protection program.

8. Procedures/policies provide for appropriate notifications of fire protection system outages.

9. Provisions are made for the proper storage of radioactive, flammable, and combustible materials.

10. Fire emergency procedures are established and implemented.

11. Means of controlling liquid run-offs from a credible fire are provided so that contaminated (including nonradiological containments) liquids, including potentially contaminated water resulting from fire fighting operations, will not escape to the environment.

\section{Approach:}

1. Identify and review procedures related to fire protection. Verify that procedures are in place for combustible and flammable materials, hot work including cutting and welding, smoking, and fire protection system impairments. Inspect existing conditions to determine implementation of the identified procedures. 
2. Review the Fire Hazards Analysis to determine that all facility areas and fire hazards are included. Determine that operating parameters were considered, including unusual operations, ventilation requirements, maintenance activities, and radiation control parameters.

3. Review the fire protection program and assure the requirements for periodic review are jdentified. Review work control procedures to confirm the requirement for independent safety review (fire protection) in the modification approval cycle. Interview engineering and Safety personnel to determine the level of understanding of the review process.

4. Verify that construction has implemented the Fire Protection requirements identified in Construction specifications through design and instaliation.

5. Inspect the facility to observe existing conditions for compliance to fire protection requirements, such as; 1) Proper portable fire extinguishers are mounted, marked and operable, 2) Activities site access is clear and unobstructed for emergency vehicle response, 3) Fire hydrants are accessible, 4) Exits are arranged and maintained to provide free unobstructed egress from the facility, 5) Exit routes are clearly marked and illuminated where required, 6) Emergency lighting is provided and operable where required, 7) Proper storage of radioactive, flammable and combustible material.

6. Interview the Fire Department to ensure they are cognizant of CWC's (in general) and Phase $V$ Storage (in particular) needs and have taken all appropriate actions.

7. Ensure a Pre-Fire Plan is in place which adequately encompasses the facility.

\begin{tabular}{|c|c|c|c|c|}
\hline \multirow{2}{*}{$\begin{array}{c}\text { SUBJECT/ACTIVITY } \\
\text { REQUIREMENT REFERENCE }\end{array}$} & \multirow{2}{*}{$\begin{array}{l}\text { EVIDENCE EXAMINED/ } \\
\text { PERSONNEL. CONTACTED }\end{array}$} & \multirow[t]{2}{*}{ OBSERVATIONS/COMMENTS } & \multicolumn{2}{|c|}{ COMPLY } \\
\hline & & & YES & No \\
\hline $\begin{array}{l}\text { 1) Fire Protection } \\
\text { System }\end{array}$ & $\begin{array}{l}\text { Fire Protection water } \\
\text { System } \\
\text { Paul Hemsworth }\end{array}$ & $\begin{array}{l}\text { Observed that some of the valves on the } \\
\text { fire protection system are not labeled. } \\
\text { Still need to ask a Fire Protection } \\
\text { Engineer to look at the systems for proper } \\
\text { labeling }\end{array}$ & & \\
\hline
\end{tabular}




\begin{tabular}{|c|c|c|c|c|}
\hline $\begin{array}{l}\text { 2) Fire Protection } \\
\text { System }\end{array}$ & $\begin{array}{l}\text { Preventive Maintenance } \\
\text { and Regular Maintenance } \\
\text { Paul Hemsworth }\end{array}$ & $\begin{array}{l}\text { Asked if the fire protection system is } \\
\text { tracked and completed by the Hanford Fire } \\
\text { Department. The HFD works with maintenance } \\
\text { schedulers to complete PM's and regular } \\
\text { maintenance. }\end{array}$ & $x$ & \\
\hline 3) Fire Protection & $\begin{array}{l}\text { Fire systems reviewed } \\
\text { during this core } \\
\text { Requirement review and } \\
\text { Core Requirement } 15^{\prime} \mathrm{s} \\
\text { review showed a } \\
\text { deficiency in the area } \\
\text { of installation and } \\
\text { valve tagging and was } \\
\text { reported on Finding in } \\
\text { Core requirement } 15\end{array}$ & & & $x X$ \\
\hline
\end{tabular}




\section{PHASE V STORAGE ORR APPRAISAL FORM}

CORE REQUIREMENT 8.6 - There is an adequate quality assurance organization and program.

APPROACH:

1. Identify and evaluate Quality Assurance Program documentation for adequacy and assess the facility for compliance to $\mathrm{WHC}-\mathrm{CM}-5-34$.

2. Review work packages to verify QA personnel approval when required.

3. Verify proper QA approval of procedures and oversight on specific work items.

4. Use WHC-CM-5-36, Chapter 4-2 and QR 19.0 to determine that the software is properly controlled and maintained.

\section{CRITERIA:}

1. The QA program is clearly defined and documented, has well defined interfaces and responsibilities, and includes

a well defined system for audits, surveillances, document review, corrective action, and follow up. There are procedures for systematic reviews and audits, inciuding self-assessments.

2. Quality assurance reports are distributed to the appropriate level of management. The reports reflect adequate and timely QA reviews.

3. Administrative controls are implemented by management to maintain control of the quality assurance program el ements.

4. Acceptance/operational tests and inspections are verified to be accurate and complete for systems important to safe operations.

5. Calibration of measurement, test, and monitoring systems are ensured and verified.

6. The QA program is effectively implemented through QA review and approval of procedures and work activities on safety class equipment and personnel safety items.

7. QA personnel have the necessary knowledge, skills and abilities to actively participate in the QA program.

(Assessed under Core Requirements 2 and 3, provided here for information and completeness).

8. Software is adequately controlled.

\begin{tabular}{|c|c|c|c|c|}
\hline $\begin{array}{c}\text { SUBJECT/ACTIVITY } \\
\text { REQUIREMENT REFERENCE }\end{array}$ & $\begin{array}{l}\text { EVIDENCE EXAMINED/ } \\
\text { PERSONNEL. CONTACTED }\end{array}$ & OBSERVATIONS/COMMENTS & COMPLY \\
\cline { 4 - 6 } & & YES & NO \\
\hline
\end{tabular}




\begin{tabular}{|c|c|c|c|}
\hline $\begin{array}{l}\text { 1) } 8.6 \\
\text { There is an adequate } \\
\text { QA Org. \& Program }\end{array}$ & $\begin{array}{l}\text { 1. QA Program } \\
\text { documented in WHC-CM-5- } \\
34 \text { sect. } 1.9 \text { \& Appen A } \\
\text { - QA program index. } \\
\text { FM - Robert Giroir } \\
\text { OPS - Paul Crane } \\
\text { QA - Dave Vance } \\
\text { ENG - Mat Irwin } \\
\text { RC - Brad Brannan } \\
\text { EC/T- Kent McDonald }\end{array}$ & $\begin{array}{l}\text { The QA Program hierarchy of documents } \\
\text { includes } 10 \text { CFR } 830.120 \text {, WHC-CM-4-2, and } \\
\text { WHC-5-34. section } 1.9 \text {. QA reports } \\
\text { independently up through the Vice } \\
\text { President ES\&H. The QA staff are hard } \\
\text { lined to that organization with dotted } \\
\text { line reporting to facility management. } \\
\text { Dave Vance is the QA representative for } \\
\text { CWC \& can draw additional resource from } \\
\text { the other QA staff members. The FDH QA } \\
\text { program is being revised and is due to be } \\
\text { issued for DOE approval by } 7 / 1 / 97 \text {. This } \\
\text { wi1l be followed within } 120 \text { days with the } \\
\text { implementing QA program and procedures } \\
\text { from RFSH which wil1 mesh with the new } \\
\text { S/RIDs and operating procedures being } \\
\text { issued by RFSH. This work is ongoing. }\end{array}$ & $x$ \\
\hline & $\begin{array}{l}\text { 2. Review work packages } \\
\text { to verify QA personne1 } \\
\text { approval when required. } \\
\text { QA - Dave Vance } \\
\text { OPN - Paul Crane } \\
\text { OPN - Mike Aichele } \\
\text { OPN - Jim Mitchel1 } \\
\text { ENG - Mat Irwin }\end{array}$ & $\begin{array}{l}\text { The responsibility for determination of QA } \\
\text { review of work packages or other work } \\
\text { control documentation is by the cog. } \\
\text { Engineer. Most work is performed as a } \\
\text { routine and work packages are seldom used } \\
\text { except for seldom performed tasks or for } \\
\text { one time unique tasks. There were no work } \\
\text { packages requiring QA review and approval. } \\
\text { The QA representative attends the POD } \\
\text { meetings and facility staff meetings and } \\
\text { provides input as requested or deemed } \\
\text { appropriate by him. Procedures are } \\
\text { reviewed and approved by the QA } \\
\text { representative }\end{array}$ & $x$ \\
\hline
\end{tabular}




\begin{tabular}{|c|c|c|c|}
\hline & $\begin{array}{l}\text { 4. WHC-CM-5-36 SWD } \\
\text { Internal Requirements - } \\
\text { SWITS Final } \\
\text { Verification \& } \\
\text { Val idation Report for } \\
\text { Initial Implementation } \\
\text { ENG - Mat Irwin } \\
\text { OPN - Paul Crane } \\
\text { ENV - Kent MCDonald } \\
\text { RC - Brad Brannan } \\
\text { SP - Dariene Hage1 } \\
\end{array}$ & $\begin{array}{l}\text { There was no software recognized by those } \\
\text { interviewed in CWC as needing application } \\
\text { of QA requirements. QR } 19.0 \text { of WHC-CM-5- } \\
36 \text {, chapter 4-2 Appendix B defines systems } \\
\text { that are subject to the software QA rqmts. } \\
\text { specified therein. The SWITS system } \\
\text { appears to meet several of these } \\
\text { requirements. Para. 5.1.3 imposes minimum } \\
\text { user requirements found in Para. } 4.4 .1 \text {. } \\
\text { The SWITS software is properly controiled } \\
\text { and maintained by the RFSH Strategic } \\
\text { Planning Org. under Ken HIadek. } \\
\text { Verification and Val idation were } \\
\text { accomplished under the requirements of } \\
\text { WHC-CM-4-2 QA Program and per IEEE STD. } \\
830-1984 \text {. Strategic Planning provides user } \\
\text { training on a } 1-0 n-1 \text { basis as required. A } \\
\text { training manual has been prepared. This } \\
\text { training is informal and undocumented due } \\
\text { to the frequent changes of user personnel. }\end{array}$ & $X$ \\
\hline
\end{tabular}




\section{PHASE V STORAGE ORR APPRAISAL FORM}

CORE REQUIREMENT: Health physics (HP) programs and procedures provide appropriate direction, effectively support safe operation of the facility, and ensure adequate protection of workers, the public, and the environment.

APPROACH: Review the organizational structure of the health physics group and its relationship to the line management structure. Determine if the organizational structure is clearly defined.

CRITERIA: Organization and administration of the HP program ensures effective implementation and control of HP activities.

\begin{tabular}{|c|c|c|c|c|}
\hline \multirow{2}{*}{$\begin{array}{l}\text { SUBJECT/ACTIVITY } \\
\text { REQUIREMENT REFERENCE }\end{array}$} & \multirow{2}{*}{$\begin{array}{l}\text { EVIDENCE EXAMINED/ } \\
\text { PERSONNEL CONTACTED }\end{array}$} & \multirow[t]{2}{*}{ OBSERVATIONS/COMMENTS } & \multicolumn{2}{|c|}{ COMPLY } \\
\hline & & & YES & NO \\
\hline $\begin{array}{l}\text { 1) Are there sufficient } \\
\text { numbers of qualified and } \\
\text { knowledgeable personnel in } \\
\text { RadCon to support safe } \\
\text { operations? (HSRCM Art. } 141.2 \text {, } \\
143.1 \text { ) }\end{array}$ & $\begin{array}{l}\text { P. B. Brannan - SWM RadCon } \\
\text { Manager } \\
\text { SWM RadCon Staffing List and } \\
\text { training files examined. }\end{array}$ & $\begin{array}{l}\text { The RadCon Manager and Health Physicist are NRRPT } \\
\text { certified. The RC organization is sufficiently staffed and } \\
\text { knowledgeable to support safe operations. }\end{array}$ & $X$ & \\
\hline $\begin{array}{l}\text { 2) Are all RPP elements } \\
\text { audi ted tri-annually? ( } 10 \mathrm{CFR} \\
835.102 \text { ) }\end{array}$ & $\begin{array}{l}\text { Self Assessment Program / } 10 \text { CFR } \\
835 \vee \& \text { process. } \\
\text { P. B. Brannan and E. J. Millikin }\end{array}$ & $\begin{array}{l}\text { The SWM RadCon staff will complete the tri-annual } \\
\text { assessment of the Radiation Protection Program by Sept. } \\
1998 \text {. Efforts are underway to complete most program } \\
\text { assessments by the end of cr'97. }\end{array}$ & $X$ & \\
\hline $\begin{array}{l}\text { 3) Do audits include program } \\
\text { content and field } \\
\text { implementation? ( } 10 \text { CFR } \\
835.102 \text { ) }\end{array}$ & $\begin{array}{l}\text { Self Assessment Program / } 10 \text { CFR } \\
835 \vee \& \text { process. } \\
\text { P. B. Brannan and E. J. Millikin }\end{array}$ & $\begin{array}{l}\text { The } 10 \text { CFR } 835 \vee \& \vee \text { process will include both program and } \\
\text { field implementation assessments. }\end{array}$ & $X$ & \\
\hline
\end{tabular}




\section{PHASE V STORAGE ORR APPRAISAL FORM}

CORE REQUIREMENT: Health physics (HP) programs and procedures provide appropriate direction, effectively support safe operation of the facility, and ensure adequate protection of workers, the public, and the environment.

APPROACH: Interview the Health Physics Manager and staff members to determine if adequate resources are provided by consistent with the radiological risk of the facility as defined in the ISB and CSER.

CRITERIA: Personnel performing health physics duties have successfuTty completed HSRCM training and qualification program. (Assessed under Core Requirements 2 and 3, provided here for information and completeness)

\begin{tabular}{|c|c|c|c|c|}
\hline \multirow{2}{*}{$\begin{array}{c}\text { SUBJECT/ACTIVITY } \\
\text { REQUIREMENT REFERENCE }\end{array}$} & \multirow{2}{*}{$\begin{array}{l}\text { EVIDENCE EXAMINED/ } \\
\text { PERSONNEL CONTACTED }\end{array}$} & \multirow[t]{2}{*}{ OBSERVATIONS/COMMENTS } & \multicolumn{2}{|c|}{ COMPLY } \\
\hline & & & YES & No \\
\hline $\begin{array}{l}\text { 1) All RCTs passed a } \\
\text { comprehensive written exam } \\
\text { within last } 2 \text { yrs? (HSRCM Art } \\
643.1 \text { ) }\end{array}$ & $\begin{array}{l}\text { RCT training files. } \\
\text { P. B. Brannan }\end{array}$ & $\begin{array}{l}\text { All RCTs have successfully passed the written exam within } \\
\text { the last two years and are qualified. }\end{array}$ & $x$ & \\
\hline $\begin{array}{l}\text { 2) All RCIs passed an Oral } \\
\text { Board with in last } 2 \text { yrs? } \\
\text { (HSRCH Art. } 643.1 \text { ) }\end{array}$ & $\begin{array}{l}\text { RCT training files. } \\
\text { P. B. Brannan }\end{array}$ & $\begin{array}{l}\text { All RCTs have successfully passed oral boards within the } \\
\text { last two years and are qualified. }\end{array}$ & $x$ & \\
\hline $\begin{array}{l}\text { 3) The facility RadCon } \\
\text { Manager has qualified as an } \\
\text { RCT and participates in } \\
\text { continuing training? (HSRCM } \\
\text { Art. 344.1) }\end{array}$ & $\begin{array}{l}\text { Soft Reporting Records. } \\
\text { P. B. Brannan }\end{array}$ & $\begin{array}{l}\text { The facility RC Manager has successfully passed written } \\
\text { exams and oral boards within the last two years and is } \\
\text { currently qualified. The RC manager participates in RCT } \\
\text { continuing training. }\end{array}$ & $x$ & \\
\hline
\end{tabular}

PHASE V STORAGE ORR APPRAISAL FORM

CORE REQUIREMENT: Health physics (HP) programs and procedures provide appropriate direction, effectively support safe operation of the facility, and ensure adequate protection of workers, the public, and the environment.

APPROACH: Review operating procedures and health physics procedures to determine their adequacy in supporting normal, process upset, and documented emergencies. Assure they were prepared in accordance with the approved writers Guide. 
CRITERIA: Programs to control radioactive material are effective in: 1) providing adequate packaging, labeling, accountability, and safe transportation of such material; and 2) minimizing the contamination of areas, equipment, and personneT.

\begin{tabular}{|c|c|c|c|c|}
\hline \multirow{2}{*}{$\begin{array}{l}\text { SUBJECT/ACTIVITY } \\
\text { REQUIREMENT REFERENCE }\end{array}$} & \multirow{2}{*}{$\begin{array}{l}\text { EVIDENCE EXAMINED/ } \\
\text { PERSONNEL CONTACTED }\end{array}$} & \multirow[t]{2}{*}{ OBSERVATIONS/COMMENTS } & \multicolumn{2}{|c|}{ COMPLY } \\
\hline & & & YES & No \\
\hline $\begin{array}{l}\text { 1) Are routines conducted at } \\
\text { radiological area boundaries. } \\
\text { (HSRCM Art. } 551 \text { ) }\end{array}$ & $\begin{array}{l}\text { Routine task Descriptions SW- } \\
\text { CWC-W035, W036, W037, M022, } \\
\text { MO23, and M024. } \\
\text { P. B. Brannan }\end{array}$ & Routine survey program meets requirements & $X$ & \\
\hline $\begin{array}{l}\text { 2) Do release procedures } \\
\text { contain release criteria and } \\
\text { are procedures compl ied with } \\
\text { in the field. (HSRCM Art. } 422 \text { ) }\end{array}$ & $\begin{array}{l}\text { POP SW-150-011/A-1, Release } \\
\text { Surveys }\end{array}$ & Procedures are adequate to ensure compl iance. & & \\
\hline $\begin{array}{l}\text { 3) Are items found to be } \\
\text { above the release criteria } \\
\text { when surveyed controlled as } \\
\text { radioactive material? (HSRCM } \\
\text { Art, 422) }\end{array}$ & $\begin{array}{l}\text { POP SH-150-011/A-1, Release } \\
\text { Surveys }\end{array}$ & Procedures are adequate to ensure compl iance. & & \\
\hline $\begin{array}{l}\text { 4) Do personnel exiting } \\
\text { radiological areas monitor in } \\
\text { accordance with posted } \\
\text { requirements? (HSRCM Art. 338) }\end{array}$ & ORR Drill exercise & $\begin{array}{l}\text { Though the CWC complex does not require exit surveys for } \\
\text { the buildings, contamination surveys were infrequently } \\
\text { performed during the observed drill. (see drill write up) }\end{array}$ & & $x$ \\
\hline
\end{tabular}




\section{PHASE V STORAGE ORR APPRAISAL FORM}

CORE REQUIREMENT: Health physics (HP) programs and procedures provide appropriate direction, effectively support safe operation of the facility, and ensure adequate protection of workers, the public, and the environment.

APPROACH: Verify exposure records are maintained for appropriate personne1.

CRITERIA: Programs to evaluate, monitor, and control internal and external radiation exposure, (e.g., dosimetry, exposure records, trend analysis, bioassay program, work area radiation records, procedures, etc.).

\begin{tabular}{|c|c|c|c|c|}
\hline \multirow{2}{*}{$\begin{array}{c}\text { SUBJECT/ACTIVITY } \\
\text { REQUIREMENT REFERENCE }\end{array}$} & \multirow{2}{*}{$\begin{array}{l}\text { EVIDENCE EXAMINED/ } \\
\text { PERSONNEL CONTACTED }\end{array}$} & \multirow[t]{2}{*}{ OBSERVATIONS/COMMENTS } & \multicolumn{2}{|c|}{ COMPLY } \\
\hline & & & YES & NO \\
\hline $\begin{array}{l}\text { 1) Does management compile } \\
\text { data and are they aware of } \\
\text { trends regarding radiation } \\
\text { exposure, radioactive waste } \\
\text { management, and contamination } \\
\text { control within the facility? } \\
\text { (HSRCM Art. 551) }\end{array}$ & $\begin{array}{l}\text { P. B. Brannan, E. J. Millikin } \\
\text { P. J. Crane, J. Mitchell }\end{array}$ & $\begin{array}{l}\text { Though management does not officially trend data, they do } \\
\text { review survey data to determine if action levels were } \\
\text { exceeded. } \\
\text { Management is aware of personnel exposure trends. }\end{array}$ & $x$ & \\
\hline $\begin{array}{l}\text { 2) Are personnel wearing } \\
\text { appropriate dosimetry when } \\
\text { entering radiological areas? } \\
\text { (HSRCM Art. 332, 334, 335) }\end{array}$ & B. Rogers and Mike Aichele & $\begin{array}{l}\text { Personnel wore appropriate dosimetry prior to entering } \\
\text { Radiation Areas. }\end{array}$ & $x$ & \\
\hline $\begin{array}{l}\text { 3) Do facility RWPs state } \\
\text { internal dosimetry } \\
\text { requirements? (HSRCM Art. 521) }\end{array}$ & $\begin{array}{l}\text { RWPs SW-001 Rev } 012, \text { SW-017 Rev } \\
010, \text { SW-046 Rev 002, SW-047 Rev } \\
002, \text { SW-050, SW-051, SW-052, SW* } \\
125 \text { Rev } 011 \text {. }\end{array}$ & $\begin{array}{l}\text { RWPs SW- } 052 \text { and SW- } 125 \text { Rev } 011 \text { state internal dosimetry } \\
\text { requirements. }\end{array}$ & $x$ & \\
\hline $\begin{array}{l}\text { 4) Does the facility have an } \\
\text { area dosimetry program? (HSRCM } \\
\text { Art. } 514 \text { ) }\end{array}$ & $\begin{array}{l}\text { J. D. Butler } \\
\text { P. B. Brannan } \\
\text { E. J. Millikin }\end{array}$ & $\begin{array}{l}\text { SWM RadCon is in the process of implementing an Area } \\
\text { Dosimetry Program. }\end{array}$ & $x$ & \\
\hline
\end{tabular}




\section{PHASE V STORAGE ORR APPRAISAL FORM}

CORE REQUIREMENT: Health physics (HP) programs and procedures provide appropriate direction, effectively support safe operation of the facility, and ensure adequate protection of workers, the pubiic, and the environment.

APPROACH: Review radiological survey procedures and techniques for the release of materials to clean areas.

CRITERIA: Programs to control radioactive material are effective in: 1) providing adequate packaging, labeling, accountability, and safe transportation of such material; and 2) minimizing the contamination of areas, equipment, and personne1.

\begin{tabular}{|c|c|c|c|c|}
\hline \multirow{2}{*}{$\begin{array}{l}\text { SUBJECT/ACTIVITY } \\
\text { REQUIREMENT REFERENCE }\end{array}$} & \multirow{2}{*}{$\begin{array}{l}\text { EVIDENCE EXAMINED/ } \\
\text { PERSONNEL CONTACTED }\end{array}$} & \multirow[t]{2}{*}{ OBSERVATIONS/COMMENTS } & \multicolumn{2}{|c|}{ COMPLY } \\
\hline & & & YES & NO \\
\hline $\begin{array}{l}\text { 1) Instruments used for } \\
\text { radiological monitoring are } \\
\text { adequate to measure the } \\
\text { intended radiation types, } \\
\text { (evels, and energies? (10 CFR } \\
835.401 . c \text { ) }\end{array}$ & ORR Drill exercise & $\begin{array}{l}\text { The RCTs who initially responded to an emergency situation } \\
\text { did not have an instrument capable of obtaining dose rates. } \\
\text { It should be noted that the back up responding RCT did have } \\
\text { a dose rate instrument. }\end{array}$ & $X$ & \\
\hline $\begin{array}{l}\text { 2) Contamination surveys } \\
\text { incorporate techniques to } \\
\text { detect both fixed and } \\
\text { removable contamination? } \\
\text { (HSRCH Art. } 554.3 \text { ) }\end{array}$ & ORR Drill exercise & $\begin{array}{l}\text { The RCTs responding to the ORR Drill did not perform swipes } \\
\text { for removable contanination (see drill write-up). }\end{array}$ & & $x$ \\
\hline $\begin{array}{l}\text { 3) Is material that has been } \\
\text { surveyed and found with } \\
\text { contamination levels greater } \\
\text { than HSRCM Table } 2-2 \text { labeled } \\
\text { and control led as radioactive } \\
\text { material? (HSRCM Art. 412) }\end{array}$ & $\begin{array}{l}\text { POP SW-150-011/A-1 Release } \\
\text { Surveys. }\end{array}$ & $\begin{array}{l}\text { Materiat stored in the CWC buildings have been posted as } \\
\text { Radioactive Material. }\end{array}$ & $X$ & \\
\hline
\end{tabular}




\section{PHASE V STORAGE ORR APPRAISAL FORM}

CORE REQUIREMENT: Health physics (HP) programs and procedures provide appropriate direction, effectively support safe operation of the facility, and ensure adequate protection of workers, the public, and the environment.

APPROACH: Ensure contamination control procedures are understood by interviewing field personne1, performing a facility tour and reviewing documentation.

CRITERIA: Contamination controls are adequate to protect the worker (e.g., PPE removal procedures are posted, contaminated and non contaminated areas are routinely surveyed, laundry procedures minimize contamination spread, air borne generating devices, such as fans and vacuum cleaners, are adequately controlled, personnel monitoring is adequate, decontamination facilities are available, proper engineered barriers, etc.).

\begin{tabular}{|c|c|c|c|c|}
\hline \multirow{2}{*}{$\begin{array}{c}\text { SUBJECT/ACTIVITY } \\
\text { REQUIREMENT REFERENCE }\end{array}$} & \multirow{2}{*}{$\begin{array}{l}\text { EVIDENCE EXAMINED/ } \\
\text { PERSONNEL CONTACTED }\end{array}$} & \multirow[t]{2}{*}{ OBSERVATIONS/COMMENTS } & \multicolumn{2}{|c|}{ COMPLY } \\
\hline & & & YES & NO \\
\hline $\begin{array}{l}\text { 1) Is monitoring of areas } \\
\text { performed to document and } \\
\text { characterize radiological } \\
\text { conditions in the workplace, } \\
\text { detect changes in radiological } \\
\text { conditions, and to control } \\
\text { potential sources of radiation } \\
\text { and/or radioactive material. } \\
\text { [10cFR835.401(a); HSRCM Art. } \\
551]\end{array}$ & $\begin{array}{l}\text { Rout ine task Descriptions SW- } \\
\text { CWC-W035, W036, WO37, M022, } \\
\text { M023, and M024. } \\
\text { P. B. Brannan }\end{array}$ & Routine survey program meets requirements. & $x$ & \\
\hline $\begin{array}{l}\text { 2) Personnel remove } \\
\text { protective clothing in a } \\
\text { manner that minimizes } \\
\text { personnel and clothing } \\
\text { contaminations and perform } \\
\text { exit surveys. } \\
\text { [10CFR835.404(g); HSRCM } \\
\text { Appendix } 3 \mathrm{C}]\end{array}$ & P. B. Brannan & $\begin{array}{l}\text { Protective Clothing is not normally required at the CWC } \\
\text { complex. Did not witness removal of } P C \text {, but discussions } \\
\text { concluded practice is adequate to prevent the spread of } \\
\text { contamination. }\end{array}$ & $x$ & \\
\hline
\end{tabular}




\section{PHASE V STORAGE ORR APPRAISAL FORM}

CORE REQUIREMENT: Health physics (HP) programs and procedures provide appropriate direction, effectively support safe operation of the facility, and ensure adequate protection of workers, the public, and the environment.

APPROACH: Review operating procedures and health physics procedures to determine their adequacy in supporting normal, process upset, and documented emergencies. Assure they were prepared in accordance with the approved Writers Guide.

CRITERIA: A documented, acceptable air monitoring program is in place, and is supported by sufficient studies (e.g., air flow patterns, particle size, etc.).

\begin{tabular}{|c|c|c|c|c|}
\hline \multirow{2}{*}{$\begin{array}{l}\text { SUBJECT/ACTIVITY } \\
\text { REQUIREMENT REFERENCE }\end{array}$} & \multirow{2}{*}{$\begin{array}{l}\text { EVIDENCE EXAMINED/ } \\
\text { PERSONNEL CONTACTED }\end{array}$} & \multirow[t]{2}{*}{ OBSERVATIONS/COMMENTS } & \multicolumn{2}{|c|}{ COMPLY } \\
\hline & & & YES & NO \\
\hline $\begin{array}{l}\text { 1) Do the type and location } \\
\text { of air sampling and monitoring } \\
\text { equipment used meet the } \\
\text { requirements of the facility } \\
\text { workplace air sampling } \\
\text { program? [10CFR835.403; HSRCM } \\
\text { Art. 555] }\end{array}$ & $\begin{array}{l}\text { WHC-SD-SQA-TA-20014 ReV } 1 \text { A } \\
\text { Workplace Air Sampl ing for CWC } \\
\text { P. B. Brannan } \\
\text { E. J. Hillikin }\end{array}$ & $\begin{array}{l}\text { The CWC buildings do not meet the criteria for Workplace } \\
\text { Air Sampling. Facility RadCon will revise the document to } \\
\text { include the } 2404 \text { series buildings. Initial studies } \\
\text { determine WPAS is not required, however, approximately one } \\
\text { month of air sample data will be evaluated prior to the } \\
\text { revision of the SD. }\end{array}$ & $X$ & \\
\hline $\begin{array}{l}\text { 2) Do the facilities have } \\
\text { record air samplers to monitor } \\
\text { all facility exhaust in } \\
\text { accordance with the ISB. (step } \\
2.1 .8 .3 \text {, pg } 2-24 \text { ) }\end{array}$ & $\begin{array}{l}\text { WHC-SD-SQA-TA-20014 Rev } 1 A \\
\text { Workplace Air Sampling for CWC } \\
\text { P. B. Brannan } \\
\text { E. J. Millikin }\end{array}$ & $\begin{array}{l}\text { An ECN was submitted to remove the "record" air sample } \\
\text { statement fron the ISB. The air sample for all cWC } \\
\text { facilities are non-record. }\end{array}$ & $X$ & \\
\hline $\begin{array}{l}\text { 3) Are monitoring and } \\
\text { workplace records including } \\
\text { airborne radioactivity } \\
\text { monitoring records maintained } \\
\text { to demonstrate compl iance with } \\
10 \text { CFR } 835 \text { Subpart E? [10 CFR } \\
835.701(\text { a) ] }\end{array}$ & $\begin{array}{l}\text { Air sample counter logs } \\
\text { P. B. Brannan } \\
\text { E. J. Millikin }\end{array}$ & $\begin{array}{l}\text { Records of air sampling data are maintained and reviewed by } \\
\text { RadCon Management. }\end{array}$ & $X$ & . \\
\hline
\end{tabular}

PHASE V STORAGE ORR APPRAISAL FORM

CORE REQUIREMENT: Health physics (HP) programs and procedures provide appropriate direction, effectively support safe operation of the facility, and ensure adequate protection of workers, the public, and the environment.

APPROACH: Verify an ALARA program has been established and is being utilized. 
CRITERIA: An ALARA program has been established and successfully implemented. ALARA program has taken into account all facets of exposure reduction (e.g., posting hot spots, shielding, special tools, monitoring, traffic routing, location of office areas and work stations, protection from transient radiation, adequate communications).

\begin{tabular}{|c|c|c|c|c|}
\hline \multirow{2}{*}{$\begin{array}{l}\text { SUBJECT/ACTIVITY } \\
\text { REQUIREMENT REFERENCE }\end{array}$} & \multirow{2}{*}{$\begin{array}{l}\text { EVIDENCE EXAMINED/ } \\
\text { PERSONNEL CONTACTED }\end{array}$} & \multirow[t]{2}{*}{ OBSERVATIONS/COMHENTS } & \multicolumn{2}{|c|}{ COMPLY } \\
\hline & & & YES & NO \\
\hline $\begin{array}{l}\text { 1) Is the ALARA process } \\
\text { appl ied to radiological work } \\
\text { as evidenced by pre-job } \\
\text { planning, pre-job briefings, } \\
\text { and ALARA reviews? } \\
\text { [10CFR835. } 101 \text { (c); HSRCM Art. } \\
311,312,313,315\end{array}$ & $\begin{array}{l}\text { HNF-CM-5-34 } \\
\text { J. D. Butler } \\
\text { J. Mitchell } \\
\text { P. J. Crane }\end{array}$ & $\begin{array}{l}\text { Discussions with facility personnel concluded that the } \\
\text { ALARA process has been applied to numerous activities } \\
\text { throughout SWM. }\end{array}$ & $X$ & \\
\hline $\begin{array}{l}\text { 2) ALARA records including } \\
\text { ALARA meeting minutes, policy } \\
\text { and management commitment, } \\
\text { assignment of } \\
\text { responsibilities, } \\
\text { optimizations, design reviews, } \\
\text { and radiological work and } \\
\text { experiment planning records } \\
\text { are maintained. } \\
\text { [10CFR835.701(a),704(b); HSRCM } \\
\text { Art. } 712(\mathrm{f}), 742]\end{array}$ & $\begin{array}{l}\text { HNF-CH-5-34 } \\
\text { J. D. Butler }\end{array}$ & $\begin{array}{l}\text { The } 5-34 \text { manual captures the policy and management } \\
\text { commitment towards ALARA. } \\
\text { The ALARA coordinator was in the process of typing the } \\
\text { minutes from previous SWM ALARA meetings. }\end{array}$ & $X$ & \\
\hline $\begin{array}{l}\text { 3) Are corrective actions in } \\
\text { response to the FEB report } \\
\text { complete? }\end{array}$ & J. D. Butler & $\begin{array}{l}\text { The due date for the new ALARA process was revised to allow } \\
\text { for the procedure review cycle. }\end{array}$ & $X$ & \\
\hline $\begin{array}{l}\text { 4) Are corrective actions in } \\
\text { response to the } F E B \text { report } \\
\text { adequate to prevent } \\
\text { recurrence? }\end{array}$ & J. D. Butler & $\begin{array}{l}\text { The revised ALARA procedure and applicable training on } \\
\text { revised process should be adequate. }\end{array}$ & $X$ & \\
\hline
\end{tabular}




\section{PHASE V STORAGE ORR APPRAISAL FORM}

CORE REQUIREMENT: Heaith physics (HP) programs and procedures provide appropriate direction, effectively support safe operation of the facility, and ensure adequate protection of workers, the public, and the environment.

APPROACH: Review documentation and tour the facility to ensure proper control of sources.

CRITERIA: Source material is adequately controlled, labeled, handled, shipped, received, and surveyed.

\begin{tabular}{|c|c|c|c|c|}
\hline \multirow{2}{*}{$\begin{array}{l}\text { SUBBJECT/ÂCTIVITY } \\
\text { REQUIREMENT REFERENCE }\end{array}$} & \multirow{2}{*}{$\begin{array}{l}\text { EVIDENCE EXAMINED/ } \\
\text { PERSONNEL CONTACTED }\end{array}$} & \multirow[t]{2}{*}{ OBSERYAT IONS/COMHENTS } & \multicolumn{2}{|c|}{ COMPLY } \\
\hline & & & YES & NO \\
\hline $\begin{array}{l}\text { 1) Are the facilities } \\
\text { contamination surveys adequate } \\
\text { to demonstrate levels outside } \\
\text { Contamination Areas are } \\
\text { maintained below Table } 2-2 \text { ? } \\
\text { HSRCM Art } 554.1 .9 \text { ) }\end{array}$ & $\begin{array}{l}\text { Routine task Descriptions SW- } \\
\text { CWC-W035, W036, W037, M022, } \\
\text { MO23, and M024. } \\
\text { P. B. Brannan }\end{array}$ & Routine survey program meets requirements & $X$ & \\
\hline $\begin{array}{l}\text { 2) Do facility personnel } \\
\text { properly package their } \\
\text { contaminated material (above } \\
\text { table } 2-2 \text { ) prior to moving } \\
\text { them to uncontrolled areas? } \\
\text { (HSRCM Art. } 413 \text { ) }\end{array}$ & $\begin{array}{l}\text { RMAs at CWC } \\
\text { P. B. Brannan } \\
\text { B Rogers }\end{array}$ & Radioactive material is properly packaged. & $X$ & \\
\hline $\begin{array}{l}\text { 3) Are RMAs posted with the } \\
\text { signs in HSRCM, Appendix H2 D, } \\
\text { Part A, \#6? }\end{array}$ & $\begin{array}{l}\text { RMAs at CWC } \\
\text { B. Rogers }\end{array}$ & $\begin{array}{l}\text { Most areas at cwC are properly posted. The Low Flash Point } \\
\text { Modules should be posted so signs are visible when doors } \\
\text { are open. }\end{array}$ & $X$ & \\
\hline $\begin{array}{l}\text { 4) Does the facility use } \\
\text { radioactive material labels } \\
\text { that list the date the } \\
\text { material was surveyed, } \\
\text { surveyor's name, radiation and } \\
\text { contamination levels, and } \\
\text { description of the item? } \\
\text { (HSRCM Art } 412.4 \text { ) }\end{array}$ & $\begin{array}{l}\text { RMAs at CWC } \\
\text { B. Rogers }\end{array}$ & $\begin{array}{l}\text { Radioactive material stored at the CWC was labeled with the } \\
\text { proper information. }\end{array}$ & $X$ & \\
\hline
\end{tabular}




\section{PHASE V STORAGE ORR APPRAISAL FORM}

CORE REQUIREMENT: Health physics (HP) programs and procedures provide appropriate direction, effectively support safe operation of the facility, and ensure adequate protection of workers, the public, and the environment.

APPROACH: Tour facility and ensure all required status boards are in place to properly define facility conditions.

CRITERIA: Facility status boards adequately represent radiological conditions of the facility and provide enough information to personnel to allow safe operations and minimize exposure.

\begin{tabular}{|c|c|c|c|c|}
\hline \multirow{2}{*}{$\begin{array}{l}\text { SUBJECT/ACTIVITY } \\
\text { REQUIREMENT REFERENCE }\end{array}$} & \multirow{2}{*}{$\begin{array}{l}\text { EVIDENCE EXAMINED/ } \\
\text { PERSONNEL CONTACTED }\end{array}$} & \multirow[t]{2}{*}{ OBSERVATIONS/COMMENTS } & \multicolumn{2}{|c|}{ COMPLY } \\
\hline & & & YES & No \\
\hline $\begin{array}{l}\text { 1) Does the facilities } \\
\text { radiation surveys have a } \\
\text { sufficient number of survey } \\
\text { points documented so that it } \\
\text { characterizes the area being } \\
\text { surveyed? (HSRCM Art } 551.6 \text { ) }\end{array}$ & $\begin{array}{l}\text { Rout ine task Descriptions SW- } \\
\text { CWC-W035, W036, WO37, MO22, } \\
\text { MO23, and MO24. } \\
\text { P. B. Brannan }\end{array}$ & Rout ine survey program meets requi rements. & $X$ & \\
\hline $\begin{array}{l}\text { 2) Does the facility perform } \\
\text { radiation/contamination } \\
\text { surveys before, during and } \\
\text { after a job that there is a } \\
\text { potential of change in the } \\
\text { radiological conditions? } \\
\text { (HSRCM Art } 551.8 \text { ) }\end{array}$ & $\begin{array}{l}\text { POP SW-150-005/A-3 Radioactive } \\
\text { Shipment and Receipt Surveys } \\
\text { P. B. Brannan } \\
\text { E. J. Millikin }\end{array}$ & $\begin{array}{l}\text { Procedure are adequate to ensure compliance. Field } \\
\text { observations verified procedure techniques were } \\
\text { implemented. }\end{array}$ & $X$ & \\
\hline $\begin{array}{l}\text { 3) Are results of current } \\
\text { surveys or survey maps } \\
\text { conspicuously posted to inform } \\
\text { personnel of radiological } \\
\text { conditions? (HSRCH Art. } \\
551.10 \text { ) }\end{array}$ & $\begin{array}{l}\text { J. Mitchell } \\
\text { P. B. Brannan } \\
\text { B. Rogers }\end{array}$ & $\begin{array}{l}\text { Management and workers were aware of and knew locations of } \\
\text { status boards. Workers referred to the status boards prior } \\
\text { to entering facilities to familiarize themselves with the } \\
\text { radiological conditions. }\end{array}$ & $X$ & \\
\hline
\end{tabular}




\section{PHASE V STORAGE ORR APPRAISAL FORM}

CORE REQUIREMENT: Health physics (HP) programs and procedures provide appropriate direction, effectively support safe operation of the facility, and ensure adequate protection of workers, the public, and the environment.

APPROACH: Tour facility and ensure all required posting, boundaries, radiation monitoring equipment are in place.

CRITERIA: Facility posting is adequate to provide personnel with enough information to allow safe operations and minimize exposure. Posting is in accordance with all requirements.

\begin{tabular}{|c|c|c|c|c|}
\hline \multirow{2}{*}{$\begin{array}{l}\text { SUBJECT/ACTIVITY } \\
\text { REQUIREMENT REFERENCE }\end{array}$} & \multirow{2}{*}{$\begin{array}{l}\text { EVIDENCE EXANINED/ } \\
\text { PERSONNEL CONTACTED }\end{array}$} & \multirow[t]{2}{*}{ OBSERVATIONS/COMHENTS } & \multicolumn{2}{|c|}{ COMPLY } \\
\hline & & & YES & NO \\
\hline $\begin{array}{l}\text { 1) Is each access point to } \\
\text { areas established to control } \\
\text { the spread of radioactive } \\
\text { contamination (Radiological } \\
\text { Buffer Areas, Contamination } \\
\text { Areas, High Contamination } \\
\text { Areas and Soil Contamination } \\
\text { Areas) barricaded and posted } \\
\text { to prevent inadvertent entry. } \\
\text { (10CFR835.501, HSRCM Art 231j }\end{array}$ & $\begin{array}{l}\text { Tour of CWC } \\
\text { P. B. Brannan } \\
\text { B Rogers } \\
\text { M. Aichele }\end{array}$ & $\begin{array}{l}\text { The CWC does not meet the requirements for posting areas } \\
\text { for these areas. The buildings are correctly posted for } \\
\text { the radiological conditions present. } \\
\text { The spill kit inspected east of } 2404-\text { WB had out dated } \\
\text { radiological signs stored inside, Current radiological } \\
\text { signs should be stored in the spill kits. }\end{array}$ & & $X$ \\
\hline $\begin{array}{l}\text { 2) Physical barriers are } \\
\text { placed such that they are } \\
\text { clearly visible from all entry } \\
\text { approaches. (HSRCM Art } 231.10 \text { ) }\end{array}$ & $\begin{array}{l}\text { Tour of CHC } \\
\text { P. B. Brannan } \\
\text { B Rogers } \\
\text { M. Aichele }\end{array}$ & $\begin{array}{l}\text { With the exception for the Low Flash Point Modules, all } \\
\text { access points to the radiological areas are properly posted } \\
\text { and controlled. }\end{array}$ & $X$ & \\
\hline $\begin{array}{l}\text { 3) Are routine task in place } \\
\text { to ensure posting is adequate } \\
\text { for the radiological } \\
\text { conditions present? (HSRCM } \\
\text { Art } 231.5 \text { ) }\end{array}$ & $\begin{array}{l}\text { Routine task Descriptions SW- } \\
\text { CWC-W035, W036, W037, M022, } \\
\text { M023, and M024. } \\
\text { P. B. Brannan }\end{array}$ & Routine survey program meets requirements. & $X$ & \\
\hline
\end{tabular}




\section{PHASE V STORAGE ORR APPRAISAL FORM}

CORE REQUIREMENT: Health physics (HP) programs and procedures provide appropriate direction, effectively support safe operation of the facility, and ensure adequate protection of workers, the public, and the environment.

APPROACH: Review and selected RWPs used in critical process areas for applicability, correct controls, accuracy, and completeness.

CRITERIA: Facility Radiological Work Permits (RWPs) are adequate to protect the worker, public, and environment. RWPs contain adequate provisions for protective equipment, work 1 imitations, job descriptions, and special instructions. RWPs are posted at entrances to work areas. Out-of-date RWPs are removed in a timely manner.

\begin{tabular}{|c|c|c|c|c|}
\hline \multirow{2}{*}{$\begin{array}{l}\text { SUBJECT/ACTIVITY } \\
\text { REQUIREMENT REFERENCE }\end{array}$} & \multirow{2}{*}{$\begin{array}{l}\text { EVIDENCE EXANINED/ } \\
\text { PERSONNEL CONTACTED }\end{array}$} & \multirow[t]{2}{*}{ OBSERVATIONS/COMMENTS } & \multicolumn{2}{|c|}{ COMPLY } \\
\hline & & & YES & NO \\
\hline $\begin{array}{l}\text { 1) Do radiological workers } \\
\text { fol low the requi rements in } \\
\text { Radiation Work Permi ts, } \\
\text { radiological work procedures, } \\
\text { and technical work documents? } \\
\text { (HSRCM Art } 341.1 \text { ) }\end{array}$ & $\begin{array}{l}\text { Tour of CWC } \\
\text { B Rogers }\end{array}$ & $\begin{array}{l}\text { Radiological worker wore proper dosimetry and met all entry } \\
\text { requi rements of the RWP. }\end{array}$ & $x$ & \\
\hline $\begin{array}{l}\text { 2) Are radiological workers } \\
\text { following the requirements of } \\
\text { Radiation Work Permits, } \\
\text { including Personal Protective } \\
\text { clothing and Equipment, } \\
\text { dosimeters, and frisking as } \\
\text { required by RWP? (HSRCM Art } \\
321,325,338 \text { ) }\end{array}$ & $\begin{array}{l}\text { Tour of CWC } \\
\text { B Rogers }\end{array}$ & $\begin{array}{l}\text { Though PPE and frisking are not nornally required at cwc, } \\
\text { radiological worker wore proper dosimetry and met all entry } \\
\text { requirements of the RWP. }\end{array}$ & $x$ & \\
\hline $\begin{array}{l}\text { 3) Are RWPs posted at the } \\
\text { access points to the } \\
\text { appt icable radiological work } \\
\text { area? (HSRCM Art } 322.6 \text { ) }\end{array}$ & $\begin{array}{l}\text { Tour of CWC } \\
\text { B Rogers }\end{array}$ & RWPS are posted at the ACES station. & $x$ & \\
\hline
\end{tabular}

PHASE V STORAGE ORR APPRAISAL FORM

\section{CORE REQUIREMENT: 8.8}

Industrial hygiene and safety programs, policies, and procedures have been developed which are consistent with the hazards present or anticipated in the working environment as well as with DOE Orders and OSHA standards. The overall 
program is effectively managed to promptly address and remedy hazards, and systems are in place to communicate information to workers in order to prevent occupational injuries and ilinesses.

\section{Criteria:}

1. A formal safety and health program has been developed which includes procedures and policies consistent with DOE Orders and OSHA.

5. Sufficient work place surveillance exists to seek and track safety and health hazards. Regular and periodic audits are conducted to assess work place conditions.

8. As a minimum Industrial Safety, Industrial Hygiene, and Nuclear Safety should have assessed the following: A - 1. Work area is safe.

\section{Approach :}

1. A review of all relevant aspects of the formal safety and health program will be undertaken to evaluate the content for accuracy, adequacy, and consistency with DOE Orders and OSHA.

2. Safety and health resources, such as staffing, equipment, and the availability of reference resources will be evaluated to determine whether knowledge and tools exist to operate and manage an effective program.

3. Review the frequency of scheduled safety inspections to assure it meets the needs of the facility's mission objective.

4. Review records to determine if they are properly maintained. This review will include injury and illness records and inspection records.

5. A physical walk through of selected areas of the facility will be performed to observe actual work site conditions and practices to assess compliance with existing requirements

\begin{tabular}{||c|c|c|c||}
\hline $\begin{array}{c}\text { SUBJECT/ACTIVITY } \\
\text { REQUIREMENT REFERENCE }\end{array}$ & $\begin{array}{l}\text { EVIDENCE EXAMINED/ } \\
\text { PERSONNEL CONTACTED }\end{array}$ & OBSERVATIONS/COMMENTS & COMPLY \\
\cline { 4 - 5 } & & & YES \\
\hline
\end{tabular}




\begin{tabular}{|c|c|c|c|}
\hline $\begin{array}{l}\text { 1) Confined Space } \\
\text { program. } \\
29 \text { CFR } 1910.146\end{array}$ & $\begin{array}{l}\text { Facility walkdown } \\
\text { Gary Mickle }\end{array}$ & $\begin{array}{l}\text { All areas that appear to be possible } \\
\text { confined spaces are labeled as such. } \\
\text { Individuals knew the classification } \\
\text { criteria and knew where the confined } \\
\text { spaces were. }\end{array}$ & $X$ \\
\hline $\begin{array}{l}\text { 2) Confined Space } \\
\text { Program } \\
29 \text { CFR } 1910.146\end{array}$ & $\begin{array}{l}\text { Initial } \\
\text { Characterization } \\
\text { Gary Mickle }\end{array}$ & $\begin{array}{l}\text { Mr. Mickle indicated that he was the } \\
\text { individual responsible for the } \\
\text { characterization of the confined spaces } \\
\text { and had already performed that task. }\end{array}$ & $x$ \\
\hline $\begin{array}{l}\text { 3) Confined Space } \\
\text { Program } \\
29 \text { CFR } 1910.146\end{array}$ & $\begin{array}{l}\text { Confined space } \\
\text { classification } \\
\text { Paut Crane } \\
\text { PauT Hemsworth } \\
\text { Tony McCullough } \\
\text { Jim Irvin } \\
\end{array}$ & $\begin{array}{l}\text { All individuals knew who classified the } \\
\text { confined spaces for CWC, including the new } \\
\text { storage buildings. }\end{array}$ & $x$ \\
\hline $\begin{array}{l}\text { 4) Confined Space } \\
\text { Program } \\
29 \text { CFR } 1910.146\end{array}$ & $\begin{array}{l}\text { Confined space } \\
\text { locations } \\
\text { Paul Crane } \\
\text { Paul Hemsworth } \\
\text { Tony McCullough } \\
\text { Jim Irvin } \\
\end{array}$ & $\begin{array}{l}\text { None individual knew the classification of } \\
\text { the manholes around the new storage } \\
\text { buildings, but immediately added them to } \\
\text { their lists, or knew who to ask to find } \\
\text { out. }\end{array}$ & $X$ \\
\hline 5) & & & \\
\hline
\end{tabular}




\section{PHASE V STORAGE ORR APPRAISAL FORM}

\section{CORE REQUIREMENT:}

8.8

Industrial hygiene and safety programs, policies, and procedures have been developed which are consistent with the hazards present or anticipated in the working environment as well as with DOE Orders and OSHA standards. The overal1 program is effectively managed to promptly address and remedy hazards, and systems are in place to communicate information to workers in order to prevent occupational injuries and illnesses.

\section{Criteria:}

1. A formal safety and health program has been developed which includes procedures and policies consistent with DoE Orders and OSHA.

2. Sufficient resources are available and dedicated to occupational safety and health to operate an effective program. Personnel, equipment, and reference materials are available to administer the program.

7. A system exists and is utilized whereby employees may identify safety and health hazards to their manager for corrective action without fear of reprisal. Employees are aware of their access rights to information including medical and monitoring records and Material Safety Data Sheets.

9. A system is in place and implemented to estimate quantities and assess the integrated impact of hazardous material releases on personnel and the public.

\section{Approach:}

1. A review of all relevant aspects of the formal safety and health program will be undertaken to evaluate the content for accuracy, adequacy, and consistency with DOE Orders and OSHA.

6. Employee interviews will be conducted to determine the extent of their knowledge regarding worker rights, such as Employee Concern program and access to information.

7. Review procedures and observe equipment for sampling, monitoring, and analyzing hazardous substances to ensure that provisions are in place to collect data for notification and reporting as directed by Federal and state requirements. 


\begin{tabular}{|c|c|c|c|c|}
\hline \multirow{2}{*}{$\begin{array}{c}\text { SUBJECT/ACTIVITY } \\
\text { REQUIREMENT REFERENCE }\end{array}$} & \multirow{2}{*}{$\begin{array}{l}\text { EVIDENCE EXAMINED/ } \\
\text { PERSONNEL CONTACTED }\end{array}$} & \multirow[t]{2}{*}{ OBSERVATIONS/COMMENTS } & \multicolumn{2}{|c|}{ COMPLY } \\
\hline & & & YES & No \\
\hline $\begin{array}{l}\text { 1) Hazard Communication } \\
29 \text { CFR1910.1200 }\end{array}$ & $\begin{array}{l}\text { Haz. Com. station/ } \\
\text { Paul Crane } \\
\text { Gary Mick1e } \\
\text { Paul Hemsworth } \\
\text { Tony McCullough } \\
\text { (Painter) } \\
\text { Jim Irvin (HPT) } \\
\end{array}$ & $\begin{array}{l}\text { Individuals were well aware of where the } \\
\text { Haz. Com. station was located, and who } \\
\text { administered the program in Solid waste } \\
\text { Management. }\end{array}$ & $x$ & \\
\hline 2)Haz. Com. - MSDS & $\begin{array}{l}\text { MSDS book, inventory } \\
\text { Paul Crane } \\
\text { Gary Mickle } \\
\text { Paul Hemsworth } \\
\text { Tony McCuIlough } \\
\text { Jim Irvin } \\
\end{array}$ & $\begin{array}{l}\text { A11 individuals were asked to show they } \\
\text { understood the information contained in a } \\
\text { few MSDS's. A17 of the people interviewed } \\
\text { demonstrated how to read an MSDS and what } \\
\text { the information means. }\end{array}$ & $x$ & \\
\hline 3) & & & & \\
\hline
\end{tabular}


Core Requirement 8.8 Industrial Hygiene and safety programs, policies, and procedures have been developed which are consistent with the hazards present or anticipated in the working environment as well as with DOE Orders and OSHA standards. The overall program is effectively managed to promptly address and remedy hazards, and systems are in place to communicate information to workers in order to prevent occupational injuries and illnesses.

Approach 1 A review of all relevant aspects of the formal safety and health program will be undertaken to evaluate the content for accuracy, adequacy, and consistency with DOE orders and OSHA.

Criteria $1 \mathrm{~A}$ formal safety and health program has been developed which includes procedures and policies consistent with DOE orders and OSHA.

\begin{tabular}{|c|c|c|c|c|}
\hline \multirow{2}{*}{$\begin{array}{l}\text { SUBJECT/ACTIVITY } \\
\text { REQUIREMENT REFERENCE }\end{array}$} & \multirow{2}{*}{$\begin{array}{l}\text { EVIDENCE EXAMINED/ } \\
\text { PERSONNEL CONTACTED }\end{array}$} & \multirow{2}{*}{ OBSERVATIONS/COMMENTS } & \multicolumn{2}{|c|}{ COMPLY } \\
\hline & & & YES & NO \\
\hline 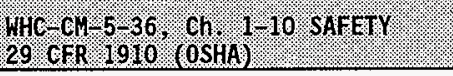 & & 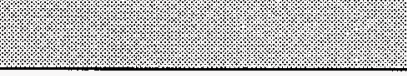 & & \\
\hline $\begin{array}{l}\text { 1. Review the Health and Safety } \\
\text { PIan (HASP). } \\
\text { Interview the facility safety } \\
\text { rep. and selected management and } \\
\text { operators to determine if the } \\
\text { knowledge of the HASP is } \\
\text { adequate. } \\
\text { Does the safety and health } \\
\text { program contain the following } \\
\text { elements: } \\
\text { - Organizational structure } \\
\text { - comprehensive work plan } \\
\text { - site-specific safety and } \\
\text { health plan } \\
\text { - safety and health training } \\
\text { program } \\
\text { - medical surveillance } \\
\text { program }\end{array}$ & $\begin{array}{l}\text { CWC HASP } \\
\text { Valerie Mitche11 } \\
\text { Gary Mickle }\end{array}$ & All appears to be in order & $x x$ & \\
\hline
\end{tabular}




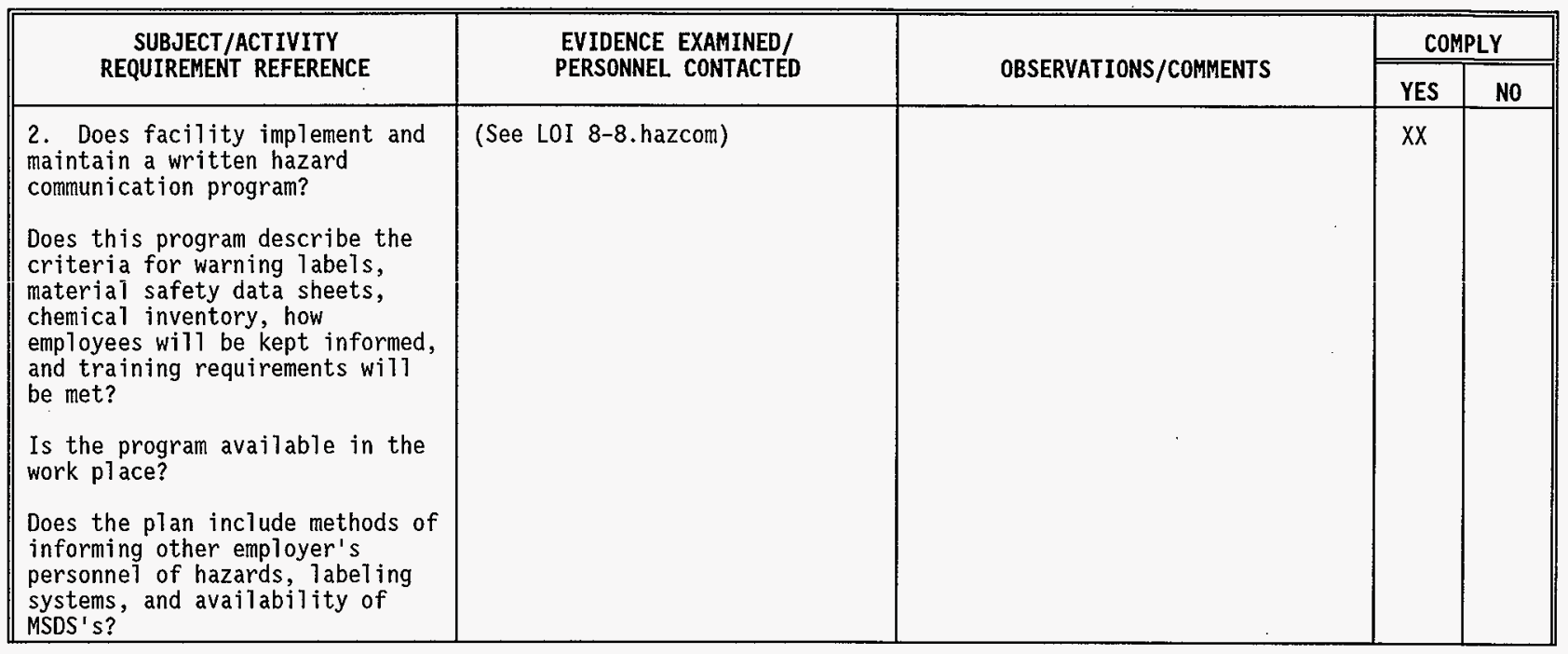




\begin{tabular}{|c|c|c|c|c|}
\hline \multirow{2}{*}{$\begin{array}{c}\text { SUBJECT/ACTIVITY } \\
\text { REQUIREMENT REFERENCE }\end{array}$} & \multirow{2}{*}{$\begin{array}{l}\text { EVIDENCE EXAMINED/ } \\
\text { PERSONNEL CONTACTED }\end{array}$} & \multirow{2}{*}{ OBSERVATIONS/COMMENTS } & \multicolumn{2}{|c|}{ COMPLY } \\
\hline & & & YES & NO \\
\hline $\begin{array}{l}\text { 3. Does facility have a } \\
\text { material data sheet for each } \\
\text { hazardous chemical which they } \\
\text { use? } \\
\text { Do any of the MSDS's have any } \\
\text { areas not completed? } \\
\text { Are MSDS's current, and } \\
\text { accurate? } \\
\text { Are MSDS's readily available to } \\
\text { workers in the work place? } \\
\text { (Review a few MSDS's at their } \\
\text { location.) }\end{array}$ & $\begin{array}{l}\text { No problems were observed in } \\
\text { this area after reviewing a few } \\
\text { MSDS's. There is very little } \\
\text { chemicals in use in the } \\
\text { facility other than the waste } \\
\text { that is being stored. } \\
\text { V. Mitchell } \\
\text { G. Mickle } \\
\text { B. Rogers } \\
\text { M. Aichele }\end{array}$ & & $X X$ & \\
\hline $\begin{array}{l}\text { 4. Prior to work, is all } \\
\text { information concerning chemical, } \\
\text { physical, toxicologic properties } \\
\text { of substances to be encountered } \\
\text { communicated to employees? }\end{array}$ & $\begin{array}{l}\text { This is done we11 } \\
\text { V. Mitche11 } \\
\text { G. Mickle } \\
\text { B. Rogers }\end{array}$ & & $X X$ & \\
\hline $\begin{array}{l}\text { 5. Do operating procedures } \\
\text { provide direction to ensure that } \\
\text { potential hazards are identified } \\
\text { for correction, and do they } \\
\text { ensure that safety requirements } \\
\text { are uniformly implemented? }\end{array}$ & $\begin{array}{l}\text { This area was reviewed } \\
\text { thoroughly in Core Requirement } \\
1\end{array}$ & & $X X$ & \\
\hline
\end{tabular}

Approach 2 Safety and Health resources, such as staffing, equipment and the availability of reference resources will be evaluated to determine whether knowledge and tools exist to operate and manage an effective program. 
Criteria 2 Sufficient resources are available and dedicated to occupational safety and health to operate an effective program. Personnel, equipment, and reference materials are available to administer the program.

\begin{tabular}{|c|c|c|c|c|}
\hline \multirow{2}{*}{$\begin{array}{c}\text { SUBJECT/ACTIVITY } \\
\text { REQUIREMENT REFERENCE }\end{array}$} & \multirow{2}{*}{$\begin{array}{l}\text { EVIDENCE EXAMINED/ } \\
\text { PERSONNEL CONTACTED }\end{array}$} & \multirow{2}{*}{ OBSERVATIONS/COMMENTS } & \multicolumn{2}{|c|}{ COMPLY } \\
\hline & & & YES & NO \\
\hline 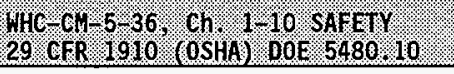 & G. & & & \\
\hline $\begin{array}{l}\text { 1. Are qualified staff assigned } \\
\text { to direct and operate the safety } \\
\text { program? }\end{array}$ & $\begin{array}{l}\text { The two safety individuals are } \\
\text { well qualified with proper } \\
\text { credentials to operate the } \\
\text { safety program. }\end{array}$ & & $x x$ & \\
\hline $\begin{array}{l}\text { 2. Does the safety staff have } \\
\text { sufficient time and availability } \\
\text { to fully implement the program? }\end{array}$ & $\begin{array}{l}\text { They are stretched to the limit } \\
\text { in many areas but appear to be } \\
\text { able to cover the area } \\
\text { sufficiently. }\end{array}$ & & $x x$ & \\
\hline $\begin{array}{l}\text { 3. Does the safety staff have } \\
\text { the authority necessary to fully } \\
\text { implement the program? }\end{array}$ & $\begin{array}{l}\text { The safety staff has the } \\
\text { authority needed. The operators } \\
\text { also feel they have the } \\
\text { authority if needed. } \\
\text { B. Rogers }\end{array}$ & & $X X$ & \\
\hline $\begin{array}{l}\text { 4. Are qualified Industrial } \\
\text { Hygienists identified and } \\
\text { available for consultation with } \\
\text { line management? }\end{array}$ & $\begin{array}{l}\text { Valerie Mitchell is an } \\
\text { Industrial Hygienist and is on } \\
\text { the staff at CWC. }\end{array}$ & & $x x$ & \\
\hline $\begin{array}{l}\text { 5. Have facility specific } \\
\text { safety issues been identified, } \\
\text { and have established practices } \\
\text { for prioritizing spending for } \\
\text { capital improvement projects } \\
\text { factor in safety issues as a } \\
\text { high priority? }\end{array}$ & $\begin{array}{l}\text { The preoccupancy checklist } \\
\text { inspection was thorough and } \\
\text { well documented except in the } \\
\text { area of illumination. This was } \\
\text { noted on finding F.8-8.1 as a } \\
\text { prestart finding. }\end{array}$ & . & & $x X$ \\
\hline
\end{tabular}




\begin{tabular}{||l|l|l|l|}
\hline \multicolumn{1}{|c|}{$\begin{array}{c}\text { SUBJECT/ACTIVITY } \\
\text { REQUIREMENT REFERENCE }\end{array}$} & \multicolumn{1}{|c|}{$\begin{array}{c}\text { EVIDENCE EXAMINED/ } \\
\text { PERSONNEL CONTACTED }\end{array}$} & OBSERVATIONS/COMMENTS \\
\hline \hline $\begin{array}{l}\text { 6. Is the need for specialized } \\
\text { safety equipment and technical } \\
\text { resources at the facility } \\
\text { identified? }\end{array}$ & $\begin{array}{l}\text { Well done. After discussions } \\
\text { with operators and safety } \\
\text { personnel, and observing in the } \\
\text { field, safety equaipment is } \\
\text { supplied and used properly. }\end{array}$ & YES \\
$\begin{array}{l}\text { Is specialized safety equipment } \\
\text { properly maintained in } \\
\text { accordance with approved } \\
\text { procedures? }\end{array}$ & $\begin{array}{l}\text { B. Rogers } \\
\text { M. Aichele }\end{array}$ & & XX \\
\hline
\end{tabular}

Approach 3 Review the frequency of scheduled safety inspections to assure it meets the needs of the facility's mission objective.

Criteria 5 Sufficient work place surveillance exists to seek and track safety and health hazards. Regular, and periodic audits are conducted to assess work place conditions.

\begin{tabular}{|c|c|c|c|c|}
\hline \multirow{2}{*}{$\begin{array}{c}\text { SUBJECT/ACTIVITY } \\
\text { REQUIRENENT REFERENCE }\end{array}$} & \multirow{2}{*}{$\begin{array}{l}\text { EVIDENCE EXAMINED/ } \\
\text { PERSONNEL CONTACTED }\end{array}$} & \multirow{2}{*}{ OBSERVATIONS/COMMENTS } & \multicolumn{2}{|c|}{ COMPLY } \\
\hline & & & YES & No \\
\hline 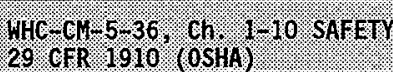 & & & & \\
\hline
\end{tabular}




\begin{tabular}{|c|c|c|c|c|}
\hline \multirow{2}{*}{$\begin{array}{c}\text { SUBJECT/ACTIVITY } \\
\text { REQUIREMENT REFERENCE }\end{array}$} & \multirow{2}{*}{$\begin{array}{l}\text { EVIDENCE EXAMINED/ } \\
\text { PERSONNEL CONTACTED }\end{array}$} & \multirow{2}{*}{ OBSERVATIONS/COMMENTS } & \multicolumn{2}{|c|}{ COMPLY } \\
\hline & & & YES & NO \\
\hline $\begin{array}{l}\text { 1. Is there a self assessment } \\
\text { program to evaluate the } \\
\text { effectiveness of the safety } \\
\text { program? } \\
\text { Is the self assessment } \\
\text { implemented through a formal } \\
\text { plan or procedure? } \\
\text { Does the self assessment program } \\
\text { incorporate feedback from } \\
\text { facility workers? }\end{array}$ & $\begin{array}{l}\text { The self assessment program in } \\
\text { effect at CWC appears to be } \\
\text { reasonably well suited for } \\
\text { finding and fixing basic safety } \\
\text { concerns. } \\
\text { G. Mickel } \\
\text { G. Whitney }\end{array}$ & & $X X$ & \\
\hline $\begin{array}{l}\text { 2. Is there a baseline survey } \\
\text { of the work area? Does it } \\
\text { document potential risks to the } \\
\text { workers? } \\
\text { Are the results of the baseline } \\
\text { document recorded, tracked and } \\
\text { ready for inspection? }\end{array}$ & $\begin{array}{l}\text { This has been documented on } \\
\text { F.8.8.1 as previously } \\
\text { mentioned. }\end{array}$ & & & $x X$ \\
\hline $\begin{array}{l}\text { 3. Are periodic walk through } \\
\text { surveys of the work place } \\
\text { conducted by a safety specialist } \\
\text { and documented? Are walk } \\
\text { through findings reported } \\
\text { immediately to management, and } \\
\text { tracked to closure? }\end{array}$ & $\begin{array}{l}\text { Yes. Several of the recent } \\
\text { walkthroughs were reviewed and } \\
\text { discussed with the clsoure of } \\
\text { the items aTso being reveiwed. } \\
\text { G. Mickel } \\
\text { G. Whitney }\end{array}$ & & $x x$ & \\
\hline
\end{tabular}




\begin{tabular}{||l|l|l|l|}
\hline \multicolumn{1}{|c|}{$\begin{array}{c}\text { SUBJECT/ACTIVITY } \\
\text { REQUIREMENT REFERENCE }\end{array}$} & \multicolumn{1}{|c|}{$\begin{array}{c}\text { EVIDENCE EXANINED/ } \\
\text { PERSONNEL CONTACTED }\end{array}$} & OBSERVATIONS/COMMENTS \\
\cline { 2 - 4 } $\begin{array}{l}\text { 4. Is there a schedule of } \\
\text { safety inspections and is it } \\
\text { being followed? }\end{array}$ & $\begin{array}{l}\text { Yes. The safety staff assumes } \\
\text { this responsibility and at } \\
\text { least weekly walk around the } \\
\text { facilities and talk to the } \\
\text { workers about safety concerns. } \\
\text { G. Mickel } \\
\text { B. Rogers }\end{array}$ & NO & \\
\hline $\begin{array}{l}\text { 5. Does management perform } \\
\text { safety inspections of the plant } \\
\text { on a regular basis? Are } \\
\text { findings tracked to closure? }\end{array}$ & $\begin{array}{l}\text { Yes. The management assessment } \\
\text { program is scheduled and } \\
\text { includes safety inspections as } \\
\text { well as con. of ops. type } \\
\text { inspections. } \\
\text { G. Whitney }\end{array}$ & XX \\
\hline
\end{tabular}

Approach 4 Review records to determine if they are properly maintained. This review will include injury and illness records and inspection records.

Criteria 3 Appropriate record keeping procedures have been established to document injuries, illnesses, and accident occurrences and to permit the ready analysis of such records.

Criteria 6 Noncompliant conditions are documented, corrective actions dates established, and tracking programs implemented to assure prompt abatement of observed hazards. Where engineering or administrative controls are not readily implemented, personal protective equipment is available and used to provide employee protection.

\begin{tabular}{|c|c|c|c|c|}
\hline \multirow{2}{*}{$\begin{array}{c}\text { SUBJECT/ACTIVITY } \\
\text { REQUIREMENT REFERENCE }\end{array}$} & \multirow{2}{*}{$\begin{array}{l}\text { EVIDENCE EXAMINED/ } \\
\text { PERSONNEL CONTACTED }\end{array}$} & \multirow{2}{*}{ OBSERVATIONS/COMMENTS } & \multicolumn{2}{|c|}{ COMPLY } \\
\hline & & & YES & NO \\
\hline 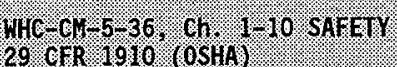 & & & & \\
\hline
\end{tabular}




\begin{tabular}{|c|c|c|c|c|}
\hline \multirow{2}{*}{$\begin{array}{c}\text { SUBJECT/ACTIVITY } \\
\text { REQUIREMENT REFERENCE }\end{array}$} & \multirow{2}{*}{$\begin{array}{l}\text { EVIDENCE EXAMINED/ } \\
\text { PERSONNEL CONTACTED }\end{array}$} & \multirow{2}{*}{ OBSERVATIONS/COMMENTS } & \multicolumn{2}{|c|}{ COMPLY } \\
\hline & & & YES & NO \\
\hline $\begin{array}{l}\text { 1. Review established record } \\
\text { keeping procedures for reporting } \\
\text { and investigating illnesses, } \\
\text { injuries, and accidents. } \\
\text { Review performance indicators } \\
\text { for tracking and trending first } \\
\text { aid, recordable, etc. }\end{array}$ & $\begin{array}{l}\text { This is being done. Dsicussions } \\
\text { with safety personnel were } \\
\text { positive and records were } \\
\text { reviewed. } \\
\text { G. Mickel }\end{array}$ & & $x x$ & \\
\hline $\begin{array}{l}\text { 2. Review WRTS for open safety } \\
\text { items and timely closure. Are } \\
\text { safety items reported and } \\
\text { tracked to closure? }\end{array}$ & $\begin{array}{l}\text { A11 items being tracked. This } \\
\text { was more fully reviewed in core } \\
\text { requirement } \# 6 \text {. }\end{array}$ & & $x x$ & \\
\hline $\begin{array}{l}\text { 3. Review procedures to } \\
\text { determine if PPE is properly } \\
\text { called for. } \\
\text { Observe workers in facility to } \\
\text { determine if PPE is being } \\
\text { properly utilized. }\end{array}$ & $\begin{array}{l}\text { One possible weakness is in the } \\
\text { response to process upset } \\
\text { (drills). This is documented in } \\
\text { Core Requirements } 8.1 \text { and } 9 \text {. }\end{array}$ & & & \\
\hline $\begin{array}{l}\text { 4. Do employees understand } \\
\text { their responsibility in } \\
\text { reporting injuries, unsafe } \\
\text { conditions? }\end{array}$ & $\begin{array}{l}\text { Yes. The operators interviewed } \\
\text { showed a positive understanding } \\
\text { in their responsibility for } \\
\text { their own safety and reporting } \\
\text { any injuries. } \\
\text { B. Rogers } \\
\text { s. Kenneliy }\end{array}$ & & $x X$ & \\
\hline
\end{tabular}




\begin{tabular}{|c|c|c|c|c|}
\hline \multirow{2}{*}{$\begin{array}{c}\text { SUBJECT/ACTIVITY } \\
\text { REQUIREMENT REFERENCE }\end{array}$} & \multirow{2}{*}{$\begin{array}{l}\text { EVIDENCE EXAMINED/ } \\
\text { PERSONNEL CONTACTED }\end{array}$} & \multirow{2}{*}{ OBSERVATIONS/COMMENTS } & \multicolumn{2}{|c|}{ COMPLY } \\
\hline & & & YES & No \\
\hline $\begin{array}{l}\text { 5. Does the occurrence } \\
\text { reporting system trigger } \\
\text { investigation of incidents and } \\
\text { events that resulted, or could } \\
\text { have resulted, in occupational } \\
\text { injuries or death? }\end{array}$ & $\begin{array}{l}\text { Yes. This is more fully } \\
\text { reviewed in core requirement } \\
8.12 \text {. }\end{array}$ & & $x X$ & \\
\hline $\begin{array}{l}\text { 6. Do investigations identify } \\
\text { probable causes and corrective } \\
\text { actions to prevent recurrence os } \\
\text { similar accidents? } \\
\text { Are lessons learned from } \\
\text { investigations documented and } \\
\text { the information disseminated to } \\
\text { facility personnel? }\end{array}$ & $\begin{array}{l}\text { Yes. This was also more fully } \\
\text { reviewed in core requirement } \\
8.12 \text {. }\end{array}$ & & $x x$ & \\
\hline
\end{tabular}

Approach 5 A physical walk through of selected areas of the facility will be performed to observe actual work site conditions and practices to assess compliance with existing requirements, and the effectiveness of internal audits. As a minimum the following will be assessed: ...

Criteria 8 As a minimum Industrial Safety, Industrial Hygiene, and Nuclear Safety should have assessed the following respectively: ...

Criteria 10 Ladders, guard rails, and fall protection equipment are well maintained and meet applicable standards.

\begin{tabular}{|c|c|c|c|c|}
\hline \multirow{2}{*}{$\begin{array}{c}\text { SUBJECT/ACTIVITY } \\
\text { REQUIREMENT REFERENCE }\end{array}$} & \multirow{2}{*}{$\begin{array}{l}\text { EVIDENCE EXAMINED/ } \\
\text { PERSONNEL CONTACTED }\end{array}$} & \multirow[b]{2}{*}{ OBSERVAT IONS/COMMENTS } & \multicolumn{2}{|c|}{ COMPLY } \\
\hline & & & YES & No \\
\hline 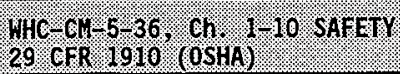 & & & & \\
\hline
\end{tabular}




\begin{tabular}{|c|c|c|c|c|}
\hline \multirow{2}{*}{$\begin{array}{l}\text { SUBJECT/ACTIVITY } \\
\text { REQUIREMENT REFERENCE }\end{array}$} & \multirow{2}{*}{$\begin{array}{l}\text { EVIDENCE EXAMINED/ } \\
\text { PERSONNEL CONTACTED }\end{array}$} & \multirow{2}{*}{ OBSERVATIONS/COMMENTS } & \multicolumn{2}{|c|}{ COMPLY } \\
\hline & & & YES & No \\
\hline $\begin{array}{l}\text { 1. Are a } 71 \text { compressed gas } \\
\text { cylinders stored and handled in } \\
\text { accordance with all applicable } \\
\text { requirements? } \\
\text { WHC-CM-5-36, Chapter } 1-10, \\
\text { Section WKS } 14 ; 29 \text { CFR1910.101; } \\
\text { PGA-1 }\end{array}$ & $N / A$ & & & \\
\hline $\begin{array}{l}\text { 2. Are al1 places of } \\
\text { employment, passageways, } \\
\text { storerooms, etc. kept clean, } \\
\text { orderly, dry, and in a sanitary } \\
\text { condition? } \\
\text { Are permanent aisles and } \\
\text { passageways marked, kept clear } \\
\text { with no obstructions? } \\
\text { Do floors used for storage have } \\
\text { their safe maximum floor load } \\
\text { posted? } \\
\text { WHC-CM-5-36, Chapter 1-10, } \\
\text { Section WKS } 18\end{array}$ & $\begin{array}{l}\text { This is well done. A walkdown } \\
\text { of the } 2404 \text { series buildings } \\
\text { was very positive that these } \\
\text { requirements are being met. } \\
\text { G. Mickel } \\
\text { B. Rogers }\end{array}$ & & $x x$ & \\
\hline
\end{tabular}




\begin{tabular}{|c|c|c|c|c|}
\hline \multirow{2}{*}{$\begin{array}{c}\text { SUBJECT/ACTIVITY } \\
\text { REQUIREMENT REFERENCE }\end{array}$} & \multirow{2}{*}{$\begin{array}{l}\text { EVIDENCE EXAMINED/ } \\
\text { PERSONNEL CONTACTED }\end{array}$} & \multirow{2}{*}{ OBSERVATIONS/COMMENTS } & \multicolumn{2}{|c|}{ COMPLY } \\
\hline & & & YES & NO \\
\hline $\begin{array}{l}\text { 3. Is there a standard guard } \\
\text { rail for open sided floors, } \\
\text { walkway, platforms, wall } \\
\text { openings or floor holes through } \\
\text { which a person may walk? Do } \\
\text { temporary floor openings have a } \\
\text { standard rail as required? } \\
\text { Is every stairway and ladderway } \\
\text { floor opening guarded by a } \\
\text { standard railing on all exposed } \\
\text { sides except at access openings? } \\
\text { Are toeboards provided at } \\
\text { exposed ladderway sides? Are } \\
\text { entrances protected by swinging } \\
\text { gate, chain (of proper height } \\
\text { and strength), or offset so that } \\
\text { persons cannot walk directly } \\
\text { into the opening? } \\
\text { Is every open-sided floor or } \\
\text { platform four feet or more above } \\
\text { adjacent floor or ground level } \\
\text { guarded by a standard guardrail } \\
\text { on all open sides? Is the } \\
\text { railing provided with a toeboard } \\
\text { where falling materials may pose } \\
\text { a hazard? } \\
\text { WHC-CM-5-36, Chapter l-10, } \\
\text { Sections WKS 18, 19 Sections }\end{array}$ & $\begin{array}{l}\text { The only concern of the } \\
\text { operators is the fixed ladder } \\
\text { that goes up the side of the } \\
\text { buildings to the roof. It's } \\
\text { under } 20^{\prime} \text { high and meets } \\
\text { minimum requirements for safety } \\
\text { equipment, but the facility is } \\
\text { planning on making it even } \\
\text { better by possibly adding a } \\
\text { safety cage to the outside of } \\
\text { the ladder. } \\
\text { G. Mickel } \\
\text { B. Rogers } \\
\text { S. Kennelly }\end{array}$ & & $x x$ & \\
\hline
\end{tabular}




\begin{tabular}{|c|c|c|c|c|}
\hline \multirow{2}{*}{$\begin{array}{l}\text { SUBJECT/ACTIVITY } \\
\text { REQUIREMENT REFERENCE }\end{array}$} & \multirow{2}{*}{$\begin{array}{l}\text { EVIDENCE EXAMINED/ } \\
\text { PERSONNEL CONTACTED }\end{array}$} & \multirow{2}{*}{ OBSERVATIONS/COMMENTS } & \multicolumn{2}{|c|}{ COMPLY } \\
\hline & & & YES & No \\
\hline $\begin{array}{l}\text { 4. Does every flight of stairs } \\
\text { with } 4 \text { or more risers have a } \\
\text { standard stair rail? } \\
\text { Are all stairway treads } \\
\text { reasonably slip-resistant and } \\
\text { the nosings of non-slip finish? } \\
\text { Is the vertical clearance above } \\
\text { any stair tread on an overhead } \\
\text { obstruction at least } 7 \text { feet from } \\
\text { the edge of the tread? }\end{array}$ & $N / A$ & & & \\
\hline $\begin{array}{l}\text { 5: Do employees working with } \\
\text { portable ladders know and follow } \\
\text { establ ished rules and safe } \\
\text { practices for ladder use? } \\
\text { Are all ladders maintained in } \\
\text { good condition at all times? } \\
\text { Are ladders safety feet in } \\
\text { p Tace and in good condition? } \\
\text { Are ladders inspected before } \\
\text { each use? }\end{array}$ & $\begin{array}{l}\text { Yes. All laders observed in } \\
\text { the facility were in good } \\
\text { shape. Although the ladders } \\
\text { are not used much, individuats } \\
\text { showed that they knew the basic } \\
\text { safety requirements for using } \\
\text { the ladders. } \\
\text { B. Rogers } \\
\text { S. Kennelly }\end{array}$ & & $X X$ & \\
\hline
\end{tabular}




\begin{tabular}{|c|c|c|c|c|}
\hline \multirow{2}{*}{$\begin{array}{l}\text { SUBJECT/ACTIVITY } \\
\text { REQUIREMENT REFERENCE }\end{array}$} & \multirow{2}{*}{$\begin{array}{l}\text { EVIDENCE EXAMINED/ } \\
\text { PERSONNEL CONTACTED }\end{array}$} & \multirow{2}{*}{ OBSERVATIONS/COMMENTS } & \multicolumn{2}{|c|}{ COMPLY } \\
\hline & & & YES & NO \\
\hline $\begin{array}{l}\text { 6. Are wooden ladders painted? } \\
\text { Is a ladder ever used to gain } \\
\text { access to a roof if it doesn't } \\
\text { extend at least } 3 \text { feet? } \\
\text { Do all metal, portable ladders } \\
\text { have rungs/steps that are } \\
\text { corrugated, knurled, dimpled, } \\
\text { coated with skip resistant } \\
\text { material to prevent possibility } \\
\text { of slipping? }\end{array}$ & $\begin{array}{l}\text { No wooden ladders were observed } \\
\text { that were painted. } \\
\text { all portable ladders observed } \\
\text { met requirements. } \\
\text { G. Micke1 }\end{array}$ & & & \\
\hline $\begin{array}{l}\text { 7. Is the clearance behind the } \\
\text { ladder a minimum of } 7^{11} \text { or are } \\
\text { the rungs appropriately arranged } \\
\text { for foot clearance? } \\
\text { Is the step across distance for } \\
\text { any fixed ladder greater than } \\
12^{11} \text { or less than } 21 / 2^{\prime \prime} \text { ? } \\
\text { Are landing platforms a proper } \\
\text { size and equipped with proper } \\
\text { railings? Is there a rung of } \\
\text { the Tadder at the landing level? } \\
\text { Do ladders have extensions or } \\
\text { grab bars at least } 31 / 2 \text { feet } \\
\text { above landing and of proper } \\
\text { construction? }\end{array}$ & $\begin{array}{l}\text { Yes. Al so see comment to item } 3 \\
\text { above. }\end{array}$ & & $X X$ & \\
\hline
\end{tabular}




\begin{tabular}{|c|c|c|c|c|}
\hline \multirow{2}{*}{$\begin{array}{l}\text { SUBJECT/ACTIVITY } \\
\text { REQUIREMENT REFERENCE }\end{array}$} & \multirow{2}{*}{$\begin{array}{l}\text { EVIDENCE EXAMINED/ } \\
\text { PERSONNEL. CONTACTED }\end{array}$} & \multirow{2}{*}{ OBSERVATIONS/COMMENTS } & \multicolumn{2}{|c|}{ COMPLY } \\
\hline & & & YES & No \\
\hline $\begin{array}{l}\text { 8. Does storage of material } \\
\text { create a hazard? ie. are items } \\
\text { stored in tiers stacked, } \\
\text { blocked, interlocked and limited } \\
\text { in height so it is stable? } \\
\text { (broken pallets) } \\
\text { Are clearance limits posted? } \\
\text { ie. fork lift speed limit signs, } \\
\text { floor loading, shelving load } \\
\text { limits }\end{array}$ & $\begin{array}{l}\text { Yes. As storage is the main } \\
\text { business of CWC all was well } \\
\text { stored. No broken pallets or } \\
\text { unstable loads were observed. } \\
\text { Floor loading is well posted. } \\
\text { G. Mickel } \\
\text { B. Rogers }\end{array}$ & & $x x$ & \\
\hline $\begin{array}{l}\text { 9. Are areas for battery } \\
\text { charging/storage designated? } \\
\text { Do battery charging/storage } \\
\text { areas have facilities for } \\
\text { flushing, and fire protection? } \\
\text { Are spill and ventilation } \\
\text { systems adequate for the battery } \\
\text { storage/charging area? } \\
\text { Are any ignition sources located } \\
\text { in charging/storage area? }\end{array}$ & $N / A$ & & & \\
\hline
\end{tabular}




\begin{tabular}{|c|c|c|c|c|}
\hline \multirow{2}{*}{$\begin{array}{c}\text { SUBJECT/ACTIVITY } \\
\text { REQUIREMENT REFERENCE }\end{array}$} & \multirow{2}{*}{$\begin{array}{l}\text { EVIDENCE EXAMINED/ } \\
\text { PERSONNEL CONTACTED }\end{array}$} & \multirow{2}{*}{ OBSERVATIONS/COMMENTS } & \multicolumn{2}{|c|}{ COMPLY } \\
\hline & & & YES & NO \\
\hline $\begin{array}{l}\text { 10. Does facility have any } \\
\text { active working areas over } 85 \\
\text { DBA? } \\
\text { Are engineering and } \\
\text { administrative controls used } \\
\text { when noise levels exceed } 85 \text { DBA } \\
\text { levels in a } 8 \text { hour time-weighted } \\
\text { average (TWA)? } \\
\text { If controls fail to bring levels } \\
\text { \& } 85 \text { DBA, is hearing protection } \\
\text { provided and used? } \\
\text { Does facility administer a } \\
\text { hearing conservation program for } \\
\text { areas with an action level of } 85 \\
\text { DBA for an eight (8) hour TWA? } \\
\text { What employees are in this h.c. } \\
\text { program? }\end{array}$ & $N / A$ & . & & \\
\hline $\begin{array}{l}\text { 11. Are signs and tags used to } \\
\text { indicate danger, warn or } \\
\text { caution? } \\
\text { Are signs correct color for } \\
\text { hazard level? } \\
\text { Is equipment properly labeled } \\
\text { for ease of understanding and } \\
\text { immediate recognition of } \\
\text { hazards? }\end{array}$ & $\begin{array}{l}\text { yes. The facility has given a } \\
\text { lot of thought into the sign } \\
\text { postings as too many are found } \\
\text { not to be effective. The signs } \\
\text { that are visible are } \\
\text { appropriate. } \\
\text { B. Rogers } \\
\text { G. Mickel }\end{array}$ & & $x x$ & \\
\hline
\end{tabular}




\begin{tabular}{|c|c|c|c|c|}
\hline \multirow{2}{*}{$\begin{array}{l}\text { SUBJECT/ACTIVITY } \\
\text { REQUIREMENT REFERENCE }\end{array}$} & \multirow{2}{*}{$\begin{array}{l}\text { EVIDENCE EXAMINED/ } \\
\text { PERSONNEL CONTACTED }\end{array}$} & \multirow{2}{*}{ OBSERVATIONS/COMMENTS } & \multicolumn{2}{|c|}{ COMPLY } \\
\hline & & & YES & NO \\
\hline $\begin{array}{l}\text { 12. Do all personnel working in } \\
\text { areas or assigned to tasks where } \\
\text { a potential for eye and face } \\
\text { injury exists wear eye } \\
\text { protection that meets the } \\
\text { requirements of ANSI z87.1-1989, } \\
\text { including side shields, } \\
\text { cleanl iness? } \\
\text { Do managers ensure that visitors } \\
\text { are provided with adequate eye } \\
\text { protection before they are } \\
\text { permitted to enter any area } \\
\text { where eye protection is } \\
\text { required, and that visitors are } \\
\text { informed of the requirements for } \\
\text { wearing eye protection in } \\
\text { designated areas? }\end{array}$ & $\begin{array}{l}\text { Very little is required in a } \\
\text { storage facility operation. } \\
\text { No specific eye protection } \\
\text { areas were observed. }\end{array}$ & & $x x$ & \\
\hline $\begin{array}{l}\text { 13. While performing physical } \\
\text { work in an operating facility or } \\
\text { job site, do employees wear } \\
\text { sturdy protective clothing that } \\
\text { covers their legs, trunks, and } \\
\text { shoulders, unless the job } \\
\text { hazards dictate more stringent } \\
\text { protective measures? } \\
\text { Do employees wear appropriate } \\
\text { gloves for all work where there } \\
\text { is reasonable risk of hand } \\
\text { injury? }\end{array}$ & $\begin{array}{l}\text { yes. All employees observed } \\
\text { working in the facility had } \\
\text { proper clothing including } \\
\text { sturdy footwear. } \\
\text { B. Rogers } \\
\text { S. Kennelly }\end{array}$ & & $x x$ & \\
\hline
\end{tabular}




\begin{tabular}{|c|c|c|c|c|}
\hline \multirow{2}{*}{$\begin{array}{c}\text { SUBJECT/ACTIVITY } \\
\text { REQUIREMENT REFERENCE }\end{array}$} & \multirow{2}{*}{$\begin{array}{l}\text { EVIDENCE EXAMINED/ } \\
\text { PERSONNEL CONTACTED }\end{array}$} & \multirow{2}{*}{ OBSERVATIONS/COMMENTS } & \multicolumn{2}{|c|}{ COMPLY } \\
\hline & & & YES & NO \\
\hline $\begin{array}{l}\text { 14. Are a1l employees who are } \\
\text { exposed to hazards that may } \\
\text { cause head injuries (falling or } \\
\text { flying objects, electric shock, } \\
\text { burns, work in areas with } \\
\text { obstructions or protruding/low- } \\
\text { hanging objects) provided with } \\
\text { appropriate protective headgear } \\
\text { per ANSI } 789.1 \text {. } \\
\text { Is protective head wear worn } \\
\text { only as designed (e.g., brim } \\
\text { forward, straps fastened, etc.). } \\
\text { Protective headgear shall not be } \\
\text { not altered or painted. }\end{array}$ & $\begin{array}{l}\text { Yes. When required proper head } \\
\text { gear is worn, although it is } \\
\text { not often required in the } \\
\text { storage faciltiy. } \\
\text { B. Rogers } \\
\text { G. Mickel }\end{array}$ & & $x x$ & \\
\hline $\begin{array}{l}\text { 15. Is personal protective } \\
\text { equipment modified without } \\
\text { specific ISFP review and } \\
\text { approval? Do employees wear } \\
\text { personal protective equipment in } \\
\text { accordance with training, } \\
\text { procedures, and instructions.? } \\
\text { Is personal protective equipment } \\
\text { maintained in an operable, } \\
\text { clean, and sanitary condition? } \\
\text { Is personal fall protection } \\
\text { equipment well maintained, meets } \\
\text { applicable requirements, and } \\
\text { employees have received training } \\
\text { and know how to use the } \\
\text { equipment? }\end{array}$ & $\begin{array}{l}\text { This is 0K. Improvement needs } \\
\text { to take place when responding } \\
\text { to process upsets as reported } \\
\text { in Core Requirements } 8.1 \text { and } 9 .\end{array}$ & & $x X$ & \\
\hline
\end{tabular}




\begin{tabular}{|c|c|c|c|c|}
\hline \multirow{2}{*}{$\begin{array}{c}\text { SUBJECT/ACTIVITY } \\
\text { REQUIREMENT REFERENCE }\end{array}$} & \multirow{2}{*}{$\begin{array}{l}\text { EVIDENCE EXAMINED/ } \\
\text { PERSONNEL CONTACTED }\end{array}$} & \multirow{2}{*}{ OBSERVATIONS/COMMENTS } & \multicolumn{2}{|c|}{ COMPLY } \\
\hline & & & YES & NO \\
\hline $\begin{array}{l}\text { 16. Are respirators properly } \\
\text { cleaned, stored, inspected, and } \\
\text { positively controlled per } \\
\text { procedure? } \\
\text { Do employees receive proper } \\
\text { training prior to using } \\
\text { respirators? }\end{array}$ & N/A & & $x X$ & \\
\hline $\begin{array}{l}\text { 17. Are al1 tools and equipment } \\
\text { (both company and employee- } \\
\text { owned) used by employees at } \\
\text { their work place in good } \\
\text { condition? }\end{array}$ & $\begin{array}{l}\text { Yes. The tools and forkl ifts } \\
\text { observed were well maintained } \\
\text { and used properly. There are } \\
\text { not a lot of hand tools in the } \\
\text { facility. } \\
\text { G. Mickel } \\
\text { B. Rogers }\end{array}$ & & $x x$ & \\
\hline
\end{tabular}




\begin{tabular}{|c|c|c|c|c|}
\hline \multirow{2}{*}{$\begin{array}{c}\text { SUBJECT/ACTIVITY } \\
\text { REQUIREMENT REFERENCE }\end{array}$} & \multirow{2}{*}{$\begin{array}{l}\text { EVIDENCE EXAMINED/ } \\
\text { PERSONNEL CONTACTED }\end{array}$} & \multirow{2}{*}{ OBSERVATIONS/COMMENTS } & \multicolumn{2}{|c|}{ COMPLY } \\
\hline & & & YES & NO \\
\hline $\begin{array}{l}\text { 18. Is every exit clearly } \\
\text { visible or the route to reach it } \\
\text { conspicuously indicated? } \\
\text { Is every exit, way of approach } \\
\text { thereto, and way of travel from } \\
\text { the exit into an open space } \\
\text { continuously maintained free of } \\
\text { all obstructions or impediments } \\
\text { to full instant use? (blockage) } \\
\text { Is the minimum width of all } \\
\text { exits more than } 28 \text { inches? Are } \\
\text { doors of the side-hinged, } \\
\text { swinging types? } \\
\text { Are there any furnishings, } \\
\text { decorations or other objects } \\
\text { placed that obstruct exits, } \\
\text { access thereto, egress } \\
\text { therefrom, or visibility } \\
\text { thereof? } \\
\text { Are all exits marked by a } \\
\text { readily visible sign? Is access } \\
\text { to exits marked }\end{array}$ & $\begin{array}{l}\text { No problems in this area were } \\
\text { observed. The emergency } 1 \text { ights } \\
\text { were found to be too low when } \\
\text { the material is stacked in the } \\
\text { buildings so they were raised. } \\
\text { otherwise the aisle widths are } \\
\text { closely monitored and } \\
\text { maintained. } \\
\text { G. Mickel } \\
\text { W. Hansen } \\
\text { B. Rogers }\end{array}$ & & $x x$ & \\
\hline
\end{tabular}




\begin{tabular}{|c|c|c|c|c|}
\hline \multirow{2}{*}{$\begin{array}{c}\text { SUBJECT / ACTIVITY } \\
\text { REQUIREMENT REFERENCE }\end{array}$} & \multirow{2}{*}{$\begin{array}{l}\text { EVIDENCE EXAMINED/ } \\
\text { PERSONNEL CONTACTED }\end{array}$} & \multirow{2}{*}{ OBSERVATIONS/COMMENTS } & \multicolumn{2}{|c|}{ COMPLY } \\
\hline & & & YES & NO \\
\hline $\begin{array}{l}\text { 19. Have all confined spaces at } \\
\text { this facility been evaluated and } \\
\text { classified as permit-required } \\
\text { spaces or non-permit-required } \\
\text { confined spaces? } \\
\text { Are a11 permit-required } \\
\text { confined spaces posted } \\
\text { "DANGER, PERMIT-REQUIRED CONF INED } \\
\text { SPACE, DO NOT ENTER"? } \\
\text { Is a written and implemented } \\
\text { confined-space entry program in } \\
\text { place? }\end{array}$ & See LOI 8.8-confined Space. & & $x x$ & \\
\hline
\end{tabular}




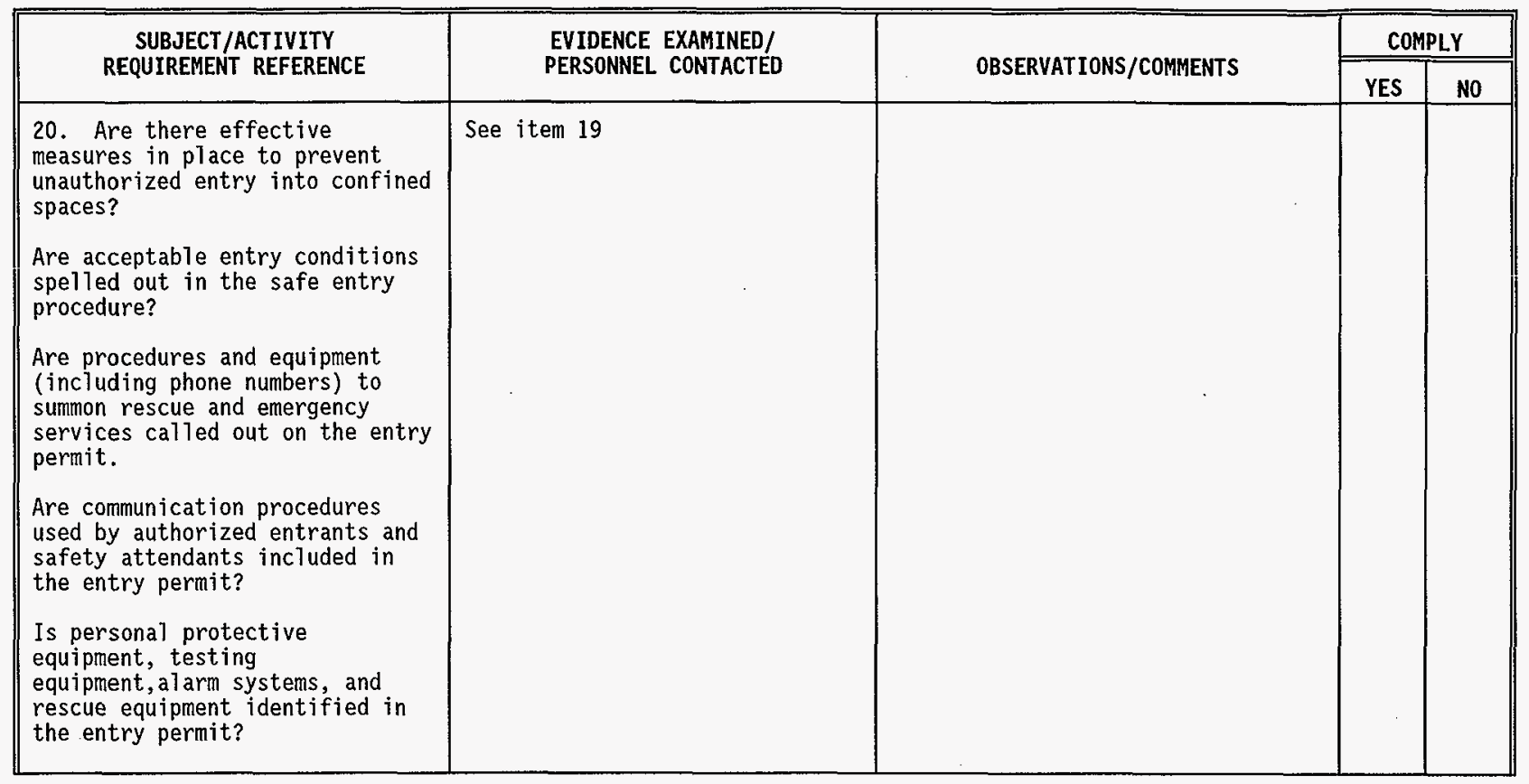




\begin{tabular}{|c|c|c|c|c|}
\hline \multirow{2}{*}{$\begin{array}{l}\text { SUBJECT/ACTIVITY } \\
\text { REQUIREMENT REFERENCE }\end{array}$} & \multirow{2}{*}{$\begin{array}{l}\text { EVIDENCE EXAMINED/ } \\
\text { PERSONNEL CONTACTED }\end{array}$} & \multirow{2}{*}{ OBSERVATIONS/COMMENTS } & \multicolumn{2}{|c|}{ COMPLY } \\
\hline & & & YES & No \\
\hline $\begin{array}{l}\text { 21. Are there suitable } \\
\text { facilities for flushing the body } \\
\text { and eyes if there is exposure to } \\
\text { corrosive materials? Is the } \\
\text { facility within the work area } \\
\text { for immediate emergency use? } \\
\text { Are routes to flushing } \\
\text { facilities kept clear at all } \\
\text { times? } \\
\text { Are safety showers/eye washes } \\
\text { checked as required? Is } \\
\text { inspection documented (tagged)? } \\
\text { Is the emergency shower location } \\
\text { identified with a highly visible } \\
\text { sign? }\end{array}$ & N/A & & & \\
\hline
\end{tabular}




\begin{tabular}{|c|c|c|c|c|}
\hline \multirow{2}{*}{$\begin{array}{l}\text { SUBJECT/ACTIVITY } \\
\text { REQUIREMENT REFERENCE }\end{array}$} & \multirow{2}{*}{$\begin{array}{l}\text { EVIDENCE EXAMINED/ } \\
\text { PERSONNEL CONTACTED }\end{array}$} & \multirow{2}{*}{ OBSERVATIONS/COMMENTS } & \multicolumn{2}{|c|}{ COMPLY } \\
\hline & & & YES & No \\
\hline $\begin{array}{l}\text { 22. Is machine guarding } \\
\text { provided where employees are } \\
\text { exposed to nip points, rotating } \\
\text { part, flying chips, or sparks? } \\
\text { Are machines guarded properly } \\
\text { when employee is exposed to } \\
\text { point of operation? } \\
\text { Are grinding wheels properly } \\
\text { guarded, dressed, with proper } \\
\text { clearances? } \\
\text { Are horizontal and vertical belt } \\
\text { drives within } 7 \text { feet of the } \\
\text { floor properly guarded? } \\
\text { Does machinery have an easily } \\
\text { accessible emergency off } \\
\text { button/switch? }\end{array}$ & $N / A$ & & & \\
\hline $\begin{array}{l}\text { 23. Are all lavatories } \\
\text { functional, potable water lines } \\
\text { disinfected and tested, back } \\
\text { flow prevention devices } \\
\text { functional, and water pressure } \\
\text { adequate? }\end{array}$ & $\begin{array}{l}\text { Yes. All appeared to be in } \\
\text { order with back flow preventers } \\
\text { identified and water pressure } \\
\text { adequate. } \\
\text { S. Kennelly } \\
\text { G. Mickel }\end{array}$ & & $x x$ & \\
\hline
\end{tabular}




\begin{tabular}{||l|l|l|l|}
\hline \multicolumn{1}{|c|}{$\begin{array}{c}\text { SUBJECT/ACTIVITY } \\
\text { REQUIREMENT REFERENCE }\end{array}$} & $\begin{array}{c}\text { EVIDENCE EXAMINED/ } \\
\text { PERSONNEL CONTACTED }\end{array}$ & OBSERVATIONS/COMMENTS \\
\cline { 2 - 4 } $\begin{array}{l}\text { Are there any LASERs in the } \\
\text { facility classified as class II } \\
\text { - IV? }\end{array}$ & N/A & YES & NO \\
$\begin{array}{l}\text { Are the lasers identified in the } \\
\text { Hazard baseline? }\end{array}$ & & \\
$\begin{array}{l}\text { Is proper eye protection } \\
\text { provided for lasers? }\end{array}$ & & \\
\hline
\end{tabular}

Approach 6 Employee interviews will be conducted to determine the extent of their knowledge regarding worker rights, such as Employee Concern program and access to information.

Approach 7 Review procedures and observe equipment for sampling, monitoring, and analyzing hazardous substances to ensure that provisions are in place to collect data for notification and reporting as directed by Federal and State requirements.

Criteria 7 A system exists and is utilized whereby employees may identify safety and health hazards to their manager for corrective action without fear of reprisal. Employees are aware of their access rights to information including medical and monitoring records and Material Safety Data Sheets.

\begin{tabular}{|c|c|c|c|c|}
\hline \multirow{2}{*}{$\begin{array}{c}\text { SUBJECT/ACTIVITY } \\
\text { REQUIRENENT REFERENCE }\end{array}$} & \multirow{2}{*}{$\begin{array}{l}\text { EVIDENCE EXAMINED/ } \\
\text { PERSONNEL CONTACTED }\end{array}$} & \multirow{2}{*}{ OBSERVATIONS/CONHENTS } & \multicolumn{2}{|c|}{ COMPLY } \\
\hline & & & YES & NO \\
\hline 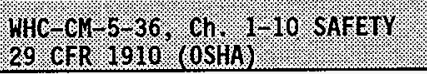 & & & & \\
\hline $\begin{array}{l}\text { 1. Do individuals know the } \\
\text { three ways to express their } \\
\text { safety concerns? (directly to } \\
\text { safety rep., directly to } \\
\text { management, safety concern } \\
\text { hotline) }\end{array}$ & $\begin{array}{l}\text { Yes. The workers and } \\
\text { individuals know of how to } \\
\text { express their safety concerns } \\
\text { and feel they are listened to. } \\
\text { S. Kennelly } \\
\text { B. Rogers }\end{array}$ & & $X X$ & \\
\hline
\end{tabular}




\begin{tabular}{|c|c|c|c|c|}
\hline \multirow{2}{*}{$\begin{array}{l}\text { SUBJECT/ACTIVITY } \\
\text { REQUIREMENT REFERENCE }\end{array}$} & \multirow{2}{*}{$\begin{array}{l}\text { EVIDENCE EXAMINED/ } \\
\text { PERSONNEL CONTACTED }\end{array}$} & \multirow{2}{*}{ OBSERVATIONS/COMMENTS } & \multicolumn{2}{|c|}{ COMPLY } \\
\hline & & & YES & No \\
\hline $\begin{array}{l}\text { 2. Do individuals know their } \\
\text { worker rights including the } \\
\text { employee concern program? Is } \\
\text { this information included in the } \\
\text { safety program? } \\
\text { CM-5-36, Ch. 1-10, WKS } 1\end{array}$ & $\begin{array}{l}\text { Yes. This is included in the } \\
\text { program and employees are } \\
\text { generally aware of their } \\
\text { rights. } \\
\text { G. Mickel } \\
\text { B. Rogers }\end{array}$ & & $x x$ & \\
\hline $\begin{array}{l}\text { 3. Are official employee } \\
\text { bullet in boards in place and do } \\
\text { they contain the master safety } \\
\text { rules (poster } 29404052.1 \text { ) and } \\
\text { Occupational Safety and Health } \\
\text { Protection for DOE Contractor } \\
\text { Employees at Government-0wned, } \\
\text { Contractor-0perated Facilities } \\
\text { (poster } 79105063.1 \text { ) } \\
\text { CM-5-36, CH. 1-10, WKS 2, P. } 3.2\end{array}$ & $\begin{array}{l}\text { Yes. The boards in M0720 were } \\
\text { reviewed and found adequate. }\end{array}$ & & $x x$ & \\
\hline
\end{tabular}




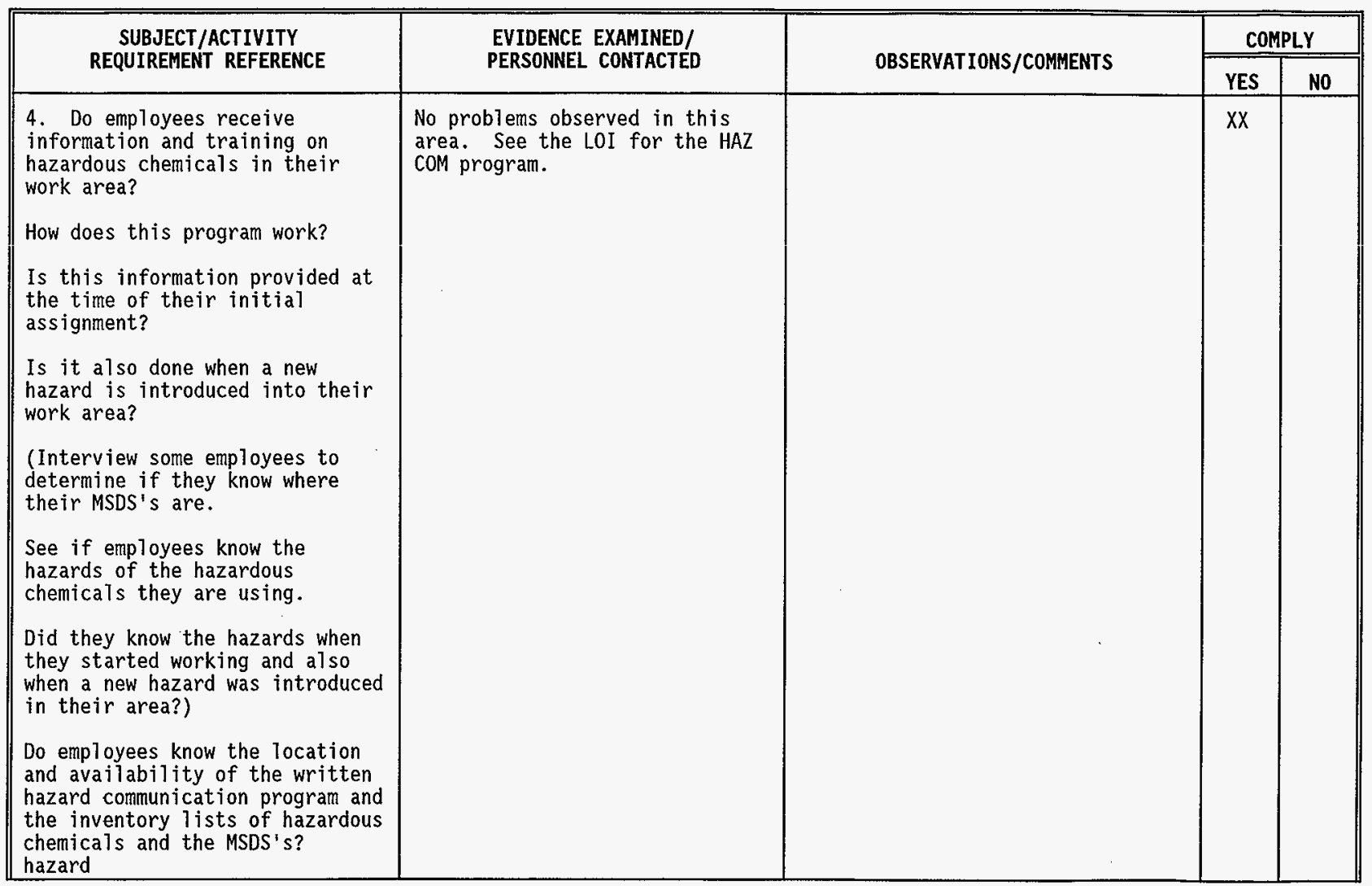




\begin{tabular}{||l|l|l|l|}
\hline \multicolumn{1}{|c|}{$\begin{array}{c}\text { SUBJECT/ACTIVITY } \\
\text { REQUIREMENT REFERENCE }\end{array}$} & \multicolumn{1}{|c|}{$\begin{array}{c}\text { EVIDENCE EXANINED/ } \\
\text { PERSONNEL CONTACTED }\end{array}$} & OBSERVATIONS/COMMENTS \\
\cline { 2 - 4 } $\begin{array}{l}\text { 5. Do employees know the } \\
\text { methods used to detect the } \\
\text { presence or release of the } \\
\text { hazardous chemica1? }\end{array}$ & $\begin{array}{l}\text { YES. Although as reported in } \\
\text { core requirement } 8.1 \text { and } 9 \text { the } \\
\text { emergency preparedness program } \\
\text { needs improvement prior to } \\
\text { start up. The various warning } \\
\text { devices in the buildings are } \\
\text { understood. }\end{array}$ & XX \\
$\begin{array}{l}\text { Do employees know what measures } \\
\text { they can take and have been } \\
\text { provided for them to avoid the } \\
\text { hazards in the work place such } \\
\text { as PPE, work practices, } \\
\text { emergency procedures? }\end{array}$ & $\begin{array}{l}\text { B. Rogers } \\
\text { S. Kennelly }\end{array}$ & & \\
\hline
\end{tabular}




\section{PHASE V STORAGE ORR APPRAISAL FORM}

\section{CORE REQUIREMENT 8.10:}

There exists an adequate configuration management program to assure necessary change and drawing control of plant structures, systems, and components and to assure changes are reflected in training, procedure development, maintenance instructions, and technical baseline.

\section{APPROACH:}

1. Review the configuration management program to determine the adequacy of facility interfaces required to maintain configuration management; proposed change review and approval; and drawing, procedure and training material configuration control.

2. Interview the responsible personnel for configuration management to assess the backlog of drawing changes, backlog of procedure changes, prioritization and action tracking scheme for facility changes, and the interfaces with maintenance, training, and operations personnel concerning impacts of new and revised drawings and procedures.

3. Confirm a program is in place and has been implemented requiring the physical walk down of systems to verify the accuracy of applicable design drawings/documentation and work plans.

4. Verify that the change control process has been adequately implemented and changes are adequately controlled.

5. Review a major change to the WRAP facilities/systems to establish that the change was properly analyzed, documented, reviewed, and incorporated.

\section{CRITERIA :}

1. Documents, drawings, and other references which define the facility configuration are readily available, authorized, properiy controlled and are used in developing training material, preparing facility procedures, work plan preparation, etc.

2. Management ensures that changes to the facility are warranted and properly controlled.

3. The configuration of systems as contained on as-built drawings have been physically verified. 
4. Procedures and management policies for changes to the facility are properly executed.

5. Configuration Management procedures/policy exists and are clearly communicated and understood by all levels of the organization.

6. Responsibilities and interfaces for configuration management are clearly defined.

7. An administrative program is in place to ensure that modifications are analyzed, documented, approved by appropriate personnel and organizations, and reflected in design drawings, new/revised procedures and training materials.

\begin{tabular}{||l|l|l|c||}
\hline \multicolumn{1}{|c|}{$\begin{array}{c}\text { SUBJECT/ACTIVITY } \\
\text { REQUIREMENT REFERENCE }\end{array}$} & \multicolumn{1}{|c|}{$\begin{array}{c}\text { EVIDENCE EXAMINED/ } \\
\text { PERSONNEL CONTACTED }\end{array}$} & OBSERVATIONS/COMMENTS & COMPLY \\
\hline $\begin{array}{l}\text { 1) Check location of } \\
\text { configuration control } \\
\text { program. }\end{array}$ & $\begin{array}{l}\text { Solid Waste Disposal } \\
\text { (SWD) documents and } \\
\text { manuals. }\end{array}$ & $\begin{array}{l}\text { WHC-CM-5-34, 2.4, contains Configuration } \\
\text { Management requirements along with WHC-CM- } \\
5-34,2.1 \text { for Configuration Change } \\
\text { Contro1. }\end{array}$ & $\times$ \\
\hline $\begin{array}{l}\text { 2) Check Location of } \\
\text { Unreviewed Safety } \\
\text { Question (USQ) } \\
\text { process. }\end{array}$ & SWD documents/manuals. & $\begin{array}{l}\text { WHC-CM-5-34, 1.24, contains the USQ } \\
\text { procedure. }\end{array}$ & $\times$ \\
\hline
\end{tabular}




\begin{tabular}{|c|c|c|c|}
\hline $\begin{array}{l}\text { 3) Evaluate } \\
\text { understanding of } \\
\text { configuration control } \\
\text { and communication. }\end{array}$ & $\begin{array}{l}\text { Discussion with Randy } \\
\text { Ames. }\end{array}$ & $\begin{array}{l}\text { Configuration Control for facility } \\
\text { equipment requires the use of approved } \\
\text { drawings. Drawing changes are controlled } \\
\text { by use of the Engineering Change Notice } \\
\text { (ECN) process. Current H-Series drawing } \\
\text { status and outstanding ECNs can be } \\
\text { determined by using Soft Reporting. } \\
\text { Discussed the post-construction "as built" } \\
\text { design drawing verification process: } \\
\text { The field configuration was verified to be } \\
\text { consistent with design drawings by a } \\
\text { thorough facility walkdown conducted by } \\
\text { Solid Waste Facility Engineering prior to } \\
\text { releasing the drawings into the facility } \\
\text { configuration management system. } \\
\text { Greatly expanded electronic document } \\
\text { access is now available with } \\
\text { implementation of the Records Management } \\
\text { Inventory System (RMIS). }\end{array}$ & $X$ \\
\hline $\begin{array}{l}\text { 4) Evaluate } \\
\text { understanding of } \\
\text { configuration control } \\
\text { and communication. }\end{array}$ & $\begin{array}{l}\text { Discussion with Mat } \\
\text { Irwin. }\end{array}$ & $\begin{array}{l}\text { Followed up on Item 2.4.1.2 from Facility } \\
\text { Evaluation Board (FEB) Report Dated March } \\
20,1997 \text { (FEB-96-0006-SWM/TP): } \\
\text { USQ records have been verified as } \\
\text { complete. All original screenings and } \\
\text { evaluations listed in the Unreviewed } \\
\text { Safety Question log are now available. } \\
\text { USQ notebooks are arranged by year, } \\
\text { numbered sequentially, and stored in a } \\
\text { fire proof cabinet. }\end{array}$ & $x$ \\
\hline
\end{tabular}




\begin{tabular}{|c|c|c|c|}
\hline $\begin{array}{l}\text { 5) Evaluate } \\
\text { understanding of } \\
\text { configuration control } \\
\text { and communication. }\end{array}$ & $\begin{array}{l}\text { Discussion with Jan Van } \\
\text { Slyke. }\end{array}$ & $\begin{array}{l}\text { Noted the configuration control and change } \\
\text { process for Plant Operations Procedures as } \\
\text { a 'Good Practice'. All current Plant } \\
\text { Operations Procedures (POPs) and all } \\
\text { associated illustrations and figures are } \\
\text { available electronically on a shared } \\
\text { drive. Changes to POPs are initiated and } \\
\text { authorized using a Document Change Request } \\
\text { (DCR) form. Draft procedure changes are } \\
\text { routed for review and approval using a } \\
\text { Document Acceptance Review Form (DARF). } \\
\text { Procedures with changes in-process are all } \\
\text { indexed on a master status tracking Tist. } \\
\text { This status list is available (read only) } \\
\text { to all employees electronically and } \\
\text { includes the responsible individual } \\
\text { currently assigned a review/comment } \\
\text { action. Once a POP revision has been } \\
\text { approved, the electronic version of the } \\
\text { new/revised procedure is made available on } \\
\text { the shared drive. A hard copy listing of } \\
\text { all current controlled PoPs is printed } \\
\text { daily for quick procedure control } \\
\text { reference (this list is also available on } \\
\text { the shared drive). An entire hard copy } \\
\text { set of all the current POPs is maintained } \\
\text { for use in the event that the network is } \\
\text { down. A revision history of procedure } \\
\text { changes, including the entire electronic } \\
\text { versions of all previous procedure } \\
\text { revisions, is available for the past two } \\
\text { (2) years. }\end{array}$ & $x$ \\
\hline
\end{tabular}




\begin{tabular}{|c|c|c|c|}
\hline $\begin{array}{l}\text { 6) Evaluate } \\
\text { understanding of } \\
\text { configuration control } \\
\text { and communication. }\end{array}$ & $\begin{array}{l}\text { Discussion with Jeff } \\
\text { Carlson. }\end{array}$ & $\begin{array}{l}\text { Training receives notification of } \\
\text { in-process and completed POP changes to } \\
\text { assist in maintaining training materials } \\
\text { current. Training also receives copies of } \\
\text { applicable ECNs. A thorough job/task } \\
\text { analysis, that began in the fall of } 1996 \text {, } \\
\text { was just completed in March, 1997. This } \\
\text { analysis used the talents of trainers, } \\
\text { operations supervision, and operators to } \\
\text { generate a. list of tasks based on current } \\
\text { procedures and operator input. This task } \\
\text { list forms the basis for upgrading the } \\
\text { operator certification packages. Initial } \\
\text { and continuing operator certification and } \\
\text { training wi11 be completely updated and } \\
\text { documented, based on current procedural } \\
\text { tasks and operational practices, by } \\
\text { September of this year. [As an aside, } \\
\text { CWC has on } 7 y \text { senior operators on staff - } \\
\text { the newest operator came to CWC in 1991.) } \\
\text { The training program has made great } \\
\text { progress in addressing the deficiencies } \\
\text { noted in the Facility Evaluation Board } \\
\text { (FEB) Report Dated March } 20 \text {, 1997 (FEB-96- } \\
\text { o006-SwM/TP) }\end{array}$ & $x$ \\
\hline
\end{tabular}




\begin{tabular}{|c|c|c|c|}
\hline $\begin{array}{l}\text { 7) Evaluate } \\
\text { understanding of } \\
\text { configuration control } \\
\text { and communication. }\end{array}$ & $\begin{array}{l}\text { Discussion with Nancie } \\
\text { Daniel. }\end{array}$ & $\begin{array}{l}\text { WHC-CM-5-34, Section } 2.1 \text {, 'Configuration } \\
\text { Change Control', directs the use of the } \\
\text { Waste Remediation Tracking System (WRTS) } \\
\text { for tracking commitments placed on the SWD } \\
\text { organization from internal and external } \\
\text { sources. However, SWD commitment tracking } \\
\text { has been completely transferred from WRTS } \\
\text { to the Hanford Action Tracking System } \\
\text { (HATS) as of January } 31 \text {, 1997. This is } \\
\text { really just an acronym (semantics) } \\
\text { discrepancy that will be corrected when } \\
\text { the new Waste Management 0perations } \\
\text { Manuals are issued in June, 1997. Though } \\
\text { WRTS and HATS are different tracking } \\
\text { systems, action tracking is the procedural } \\
\text { intent, not which program is used. All } \\
\text { entries to HATS go through the same } \\
\text { individual (s) that were responsible for } \\
\text { entry into WRTS so the entry process is } \\
\text { transparent to CWC personnel. Also, CWC } \\
\text { personnel still receive action items, but } \\
\text { now they are printed out by the HATS data } \\
\text { base. }\end{array}$ & $x$ \\
\hline $\begin{array}{l}\text { 8) Evaluate } \\
\text { understanding of } \\
\text { configuration control } \\
\text { and communication. }\end{array}$ & $\begin{array}{l}\text { Discussion with Gerry } \\
\text { Whitney. }\end{array}$ & $\begin{array}{l}\text { All new Work Plans must be verified by } \\
\text { field walkdowns. Walkdowns are usually } \\
\text { performed by the cognizant engineer and } \\
\text { operations personnel. The associated } \\
\text { Document Acceptance Review Form (DARF) } \\
\text { must be signed off before the Work Plan } \\
\text { will be issued. Discussed a Work Plan to } \\
\text { change the filter configuration at the } \\
\text { Alpha Caissons that was extensively } \\
\text { reworked as the result of differences } \\
\text { discovered during the field walkdown as an } \\
\text { illustration of the verification process } \\
\text { in action. }\end{array}$ & $x$ \\
\hline
\end{tabular}




\begin{tabular}{|c|c|c|c|}
\hline $\begin{array}{l}\text { Verify that the DOE } \\
\text { Authorization Basis } \\
\text { Approval Letter and } \\
\text { Safety Evaluation } \\
\text { Report (SER) have been } \\
\text { incorporated properly } \\
\text { into the released } \\
\text { revision of the ISB as } \\
\text { required by DOE letter } \\
97-\text { SWT-047. }\end{array}$ & $\begin{array}{l}\text { HNF-SD-WM-ISB-007, } \\
\operatorname{Rev} 1\end{array}$ & $\begin{array}{l}\text { Verified that HNF-SD-WM-ISB-007, Central } \\
\text { Waste Complex Interim Safety Basis, } \\
\text { Appendix H, incorporates the Safety } \\
\text { Evaluation Report (SER) as required. }\end{array}$ & $x$ \\
\hline $\begin{array}{l}\text { Test that operating } \\
\text { procedures and the } \\
\text { approved Interim } \\
\text { Safety Basis (ISB) are } \\
\text { compatible and that } \\
\text { the necessary controis } \\
\text { and limits have been } \\
\text { included by examining } \\
\text { an applicable } \\
\text { operating procedure. }\end{array}$ & $\begin{array}{l}\text { SW-100-110, Rev F-0 \& } \\
F-1\end{array}$ & $\begin{array}{l}\text { Reviewed the documentation trail for the } \\
\text { two (2) most recent revisions of } \\
\text { SW-100-110, Receive Radioactive Sol id } \\
\text { Waste at the Central Waste Complex, } \\
\text { (Rev/Mods F-0 \& F-1). Found that DCRs } \\
\# 130, \# 72 \text {, and } \# 44 \text { had been incorporated } \\
\text { correctly. }\end{array}$ & $x$ \\
\hline
\end{tabular}




\section{PHASE V STORAGE ORR APPRAISAL FORM}

\section{Management 8.11.1}

(Records Management)

CORE REQUIREMENT: An adequate records management/document control program exists to assure that all important documents, records, and related information are maintained current and readily retrievable.

APPROACH: 1. Review the program and procedures which define the records management system.

CRITERIA: 1. The records management program defines responsibilities for determining what documents will be controlled in a system; methods used for acquisition, identification, storage, retention, and retrieval of documents; and controls to be exercised for changes, distribution, and removal.

2. The records management program scope includes receipt or preparation, review and approval, and distribution of documents generated externally and internally in a timely manner.

3. The records management program includes processes, interfaces and responsibilities for controlling design bases and technical documents, such as calculations, specifications, drawings, vendor manuals, records of maintenance, test results, etc.

5. The document control program assures that uncontrolled drawings, manuals, and procedures are not used at the work location.

\begin{tabular}{|c|c|c|c|c|}
\hline \multirow{2}{*}{$\begin{array}{c}\text { SUBJECT/ACTIVITY } \\
\text { REQUIREMENT REFERENCE }\end{array}$} & \multirow{2}{*}{$\begin{array}{l}\text { EVIDENCE EXAMINED/ } \\
\text { PERSONNEL CONTACTED }\end{array}$} & \multirow[t]{2}{*}{ OBSERVATIONS/COMMENTS } & \multicolumn{2}{|c|}{ COMPLY } \\
\hline & & & YES & No \\
\hline $\begin{array}{l}\text { 1) Review the program } \\
\text { and procedures which } \\
\text { define the records } \\
\text { management system for } \\
\text { the attributes listed } \\
\text { in the above criteria. }\end{array}$ & $\begin{array}{l}\text { Reviewed the Solid } \\
\text { Waste Administration } \\
\text { Manual sections } \\
1.13,2.11,1.1,1.24 .2 .1 \text {, } \\
2.4\end{array}$ & $\begin{array}{l}\text { No single administrative procedure covers } \\
\text { Records Management as a program. Record } \\
\text { Management is dispersed through many } \\
\text { sections of } 5-34 \text {. } \\
\text { The following reviews of current practices } \\
\text { are sectioned into Operations, Engineering } \\
\text { and Maintenance. }\end{array}$ & & $X$ \\
\hline
\end{tabular}




\begin{tabular}{|c|c|c|c|}
\hline $\begin{array}{l}\text { a. Content } \\
\text { Doc. Control } \\
\text { Change Control }\end{array}$ & $\begin{array}{l}\text { Operations:Jan Van } \\
\text { Slyke } \\
\text { Maintenance:Pat Bott, } \\
\text { Beth Wright, Barb } \\
\text { Robinson } \\
\text { Engineering: Wil Hansen, } \\
\text { Ed Dosramos, Randy Ames }\end{array}$ & $\begin{array}{l}\text { Operations: Procedure changes are } \\
\text { controlled, tracked and implemented in a } \\
\text { very structured process. Field input, } \\
\text { engineering requirements for systems, and } \\
\text { the validation/walkdown are all retained } \\
\text { in a file. The procedure is available } \\
\text { electronically, but controlled by a single } \\
\text { individual. } \\
\text { Engineering: The engineering documents } \\
\text { are controlied per procedure and retained } \\
\text { per the EDT process. } \\
\text { Maintenance: follows the JCS process per } \\
\text { section } 2.11 \text { with work package retained } \\
\text { and retrievable through RIDS }\end{array}$ & $x$ \\
\hline b. Timeliness & same as above & $\begin{array}{l}\text { The current processes used for records } \\
\text { management met the timeliness needs of the } \\
\text { user organization. }\end{array}$ & $x$ \\
\hline c. Design Bases & Engineering & $\begin{array}{l}\text { design basis documents are being managed } \\
\text { per } 5-34 \text { and } 5-36 \text { procedures. }\end{array}$ & $x$ \\
\hline $\begin{array}{l}\text { d. Onty Controlled } \\
\text { Docs. }\end{array}$ & A11 & $\begin{array}{l}\text { Quality effecting documents are } \\
\text { appropriately identified as are specific } \\
\text { guidance memoranda issued by management. } \\
\text { Logs used by both engineering and } \\
\text { operations were being utilized and } \\
\text { controlled correctly. }\end{array}$ & $x$ \\
\hline 2) & & & \\
\hline
\end{tabular}




\section{PHASE V STORAGE ORR APPRAISAL FORM}

\section{Management 8.11.2}

\section{(Records Management)}

CORE REQUIREMENT: An adequate records management/document control program exists to assure that all important documents, records, and related information are maintained current and readily retrievable.

APPROACH: 2. Review records management program and implementing procedures in engineering, maintenance, operations, and materials management to ensure responsibilities and processes are documented for controlling technical documentation. Sample the efficiency of the system by selecting one system important to safe operations and requesting documents associated with design, procurement, construction, maintenance, and operability of one or two significant pieces of equipment in that system. Interview selected facility management to assure they are knowledgeable of records management and retention polices and procedures.

CRITERIA: 1. The records management program defines responsibilities for determining what documents will be controlled in a system; methods used for acquisition, identification, storage, retention, and retrieval of documents; and controls to be exercised for changes, distribution, and removal.

2. The records management program scope includes receipt or preparation, review and approval, and distribution of documents generated externally and internally in a timely manner.

3. The records management program includes processes, interfaces and responsibilities for controlling design bases and technical documents, such as calculations, specifications, drawings, vendor manuals, records of maintenance, test results, etc.

4. Necessary documents are kept current and legible and are either available at appropriate plant locations or can be provided in a timely manner.

5. The document control program assures that uncontrolled drawings, manuals, and procedures are not used at the work location.

\begin{tabular}{||c|c|c|c|c||}
\hline $\begin{array}{c}\text { SUBJECT/ACTIVITY } \\
\text { REQUIREMENT REFERENCE }\end{array}$ & $\begin{array}{l}\text { EVIDENCE EXAMINED/ } \\
\text { PERSONNEL CONTACTED }\end{array}$ & OBSERVATIONS/COMMENTS & COMPLY \\
\cline { 2 - 4 } & & YES & NO \\
\hline
\end{tabular}




\begin{tabular}{|c|c|c|c|}
\hline $\begin{array}{l}\text { 1) Review records } \\
\text { management program and } \\
\text { implementing } \\
\text { procedures in } \\
\text { engineering, } \\
\text { maintenance, } \\
\text { operations, and } \\
\text { materials management. } \\
\text { Ensure } \\
\text { responsibilities and } \\
\text { processes are } \\
\text { documented for } \\
\text { controlling technical } \\
\text { documentation. } \\
\end{array}$ & $\begin{array}{l}\text { Engineering: } 5-34 \\
1.24,2.1,2.4 \text { and } 5-36 \\
6.1,6.2 \\
\text { Maintenance:5-34 } 2.11 \\
\text { Operations: } 5-363.5 \\
\text { section } 12.5\end{array}$ & $\begin{array}{l}\text { A11 organizations implement the procedural } \\
\text { requirements of } 5-34 \text { and } 5-36 \text {. }\end{array}$ & $x$ \\
\hline $\begin{array}{l}\text { 2) Select one system } \\
\text { important to safe } \\
\text { operations. Request } \\
\text { documents associated } \\
\text { with design, } \\
\text { procurement, } \\
\text { construction, } \\
\text { maintenance, and } \\
\text { operability of one or } \\
\text { two significant pieces } \\
\text { of equipment in that } \\
\text { system. Verify that } \\
\text { the requested } \\
\text { documents can be } \\
\text { retrieved quickly and } \\
\text { reliably. }\end{array}$ & Pat Bott-HVAC for 2404 & $\begin{array}{l}\text { Reviewed the incorporation of the HVAC } \\
\text { system for } 2404 \text { facilities for proper } \\
\text { inclusion of operating limits per the ISB, } \\
\text { operation and maintenance per cVI data, } \\
\text { and knowledge of personnel. A1 aspects } \\
\text { of this core requirement were met. }\end{array}$ & $x$ \\
\hline $\begin{array}{l}\text { 3) Interview managers } \\
\text { responsible for the } \\
\text { records management } \\
\text { system. }\end{array}$ & $\begin{array}{l}\text { Paul Crane, Susan } \\
\text { Stitt, Matt Irwin }\end{array}$ & & \\
\hline
\end{tabular}




\begin{tabular}{|c|c|c|c|c|}
\hline $\begin{array}{l}\text { What procedures and } \\
\text { policies define the } \\
\text { records management and } \\
\text { document control } \\
\text { systems? }\end{array}$ & $\begin{array}{l}\text { WHC-5-34 and WHC-CM-5- } \\
36\end{array}$ & $\begin{array}{l}\text { The Sol id Waste Administration Manual does } \\
\text { not define a specific records management } \\
\text { program. Each organization (Engr, Ops, } \\
\text { Maint) follow separate procedures for } \\
\text { control of documents. Al1 respond } \\
\text { accordingly but an organized records } \\
\text { management program would provide better } \\
\text { efficiency. }\end{array}$ & $x$ & \\
\hline $\begin{array}{l}\text { What components are } \\
\text { vital to an accurate } \\
\text { and smoothiy } \\
\text { functioning records } \\
\text { management system? }\end{array}$ & & This could not be addressed & & $x$ \\
\hline $\begin{array}{l}\text { Describe the } \\
\text { requirements for } \\
\text { document retention. }\end{array}$ & same as above & $\begin{array}{l}\text { This varied. Ops is two years, } \\
\text { maintenance sends to RIDs for permanent } \\
\text { storage but is retrievable, and } \\
\text { Engineering uses the EDT process which is } \\
\text { also retrievable. }\end{array}$ & $x$ & \\
\hline $\begin{array}{l}\text { What actions are } \\
\text { required if a } \\
\text { controlled document is } \\
\text { "lost?" }\end{array}$ & & $\begin{array}{l}\text { Each organization responds differentiy, } \\
\text { but each also know how to retrieve. }\end{array}$ & $x$ & \\
\hline & & & & \\
\hline & & & & \\
\hline & & & & \\
\hline
\end{tabular}




\section{PHASE V STORAGE ORR APPRAISAL FORM}

\section{Management 8.11.3}

(Records Management)

CORE REQUIREMENT: An adequate records management/document control program exists to assure that all important documents, records, and related information are maintained current and readily retrievable.

APPROACH: $\quad 3$, Observe work in process involving structures, systems, and/or components, note any use of uncontrolled drawings, procedures, or manuals.

CRITERIA: 5. The document control program assures that uncontrolled drawings, manuals, and procedures are not used at the work location.

6. Documentation is stored correctly (e.g., fire proof cabinets for QA records).

\begin{tabular}{|c|c|c|c|c|}
\hline \multirow{2}{*}{$\begin{array}{c}\text { SUBJECT/ACTIVITY } \\
\text { REQUIREMENT REFERENCE }\end{array}$} & \multirow{2}{*}{$\begin{array}{l}\text { EVIDENCE EXAMINED/ } \\
\text { PERSONNEL CONTACTED }\end{array}$} & \multirow[t]{2}{*}{ OBSERVATIONS/COMMENTS } & \multicolumn{2}{|c|}{ COMPLY } \\
\hline & & & YES & No \\
\hline $\begin{array}{l}\text { 1) Observe work in } \\
\text { process. }\end{array}$ & $\begin{array}{l}\text { R Robins, B Rogers, S } \\
\text { Kennelly, J Van Slyke: } \\
\text { Log books, change } \\
\text { requests, weekly and } \\
\text { monthly surveill ances } \\
\text { sheets. }\end{array}$ & $\begin{array}{l}\text { Operations has a very credible system that } \\
\text { enables them to create, store, and retrieve } \\
\text { documents in accordance with regulations. } \\
\text { The Fire Systems generates and retains all } \\
\text { it's own records and was not reviewed in } \\
\text { detail. }\end{array}$ & $x$ & \\
\hline $\begin{array}{l}\text { Only controlled } \\
\text { documents in use? }\end{array}$ & $\begin{array}{l}\text { S Kennelly, B Rogers, R } \\
\text { Robins }\end{array}$ & $\begin{array}{l}\text { Records for the fire systems are not } \\
\text { readily retrievable by the operating } \\
\text { facility. Both operations and maintenance } \\
\text { were using controlled documents. }\end{array}$ & $x$ & \\
\hline
\end{tabular}




\begin{tabular}{||l|l|l|l|l||}
\hline $\begin{array}{l}\text { Correct revision in } \\
\text { use? }\end{array}$ & $\begin{array}{l}\text { Field walk through, D } \\
\text { Brotherton, J Van Slyke }\end{array}$ & $\begin{array}{l}\text { There were inconsistencies found on fire } \\
\text { suppression field documentation and } \\
\text { labeling. } \\
\text { The operating procedures are wel1 } \\
\text { controlled with only computer generated } \\
\text { revisions available in the field. }\end{array}$ & $X$ \\
\hline $\begin{array}{l}\text { Uncontrolled copies of } \\
\text { controlled documents } \\
\text { available? }\end{array}$ & $\begin{array}{l}\text { J Van Slyke, D } \\
\text { Brotherton, B Rogers, M } \\
\text { Aichele }\end{array}$ & $\begin{array}{l}\text { There were no uncontrolled copies of } \\
\text { controlled documents available. }\end{array}$ & $X$ \\
\hline $\begin{array}{l}\text { 2) Storage } \\
\text { requirements met? }\end{array}$ & $\begin{array}{l}\text { R Robbins, J Van Slyke, } \\
\text { B Rogers }\end{array}$ & $\begin{array}{l}\text { All record storage requirements were met } \\
\text { by the facility. } \\
\text { The daiTy operating logs are well } \\
\text { protected and being stored in a fire proof } \\
\text { safe. There are provisions in place to } \\
\text { recreate logs that have not been scanned, } \\
\text { lost. However they are not } \\
\text { proceduralized. }\end{array}$ & $X$ & $x$ \\
\hline
\end{tabular}




\section{PHASE V STORAGE ORR APPRAISAL FORM}

CORE REQUIREMENT: There exists an occurrence reporting/root cause program.

\section{APPROACH:}

1. Knowledgeable and independent (if available) personnel conduct investigations.

5. Ensure that assessment teams are supplemented with special expertise (if required) to assist in the occurrence investigation. Through discussion with cognizant personnel, determine where outside special expertise was required.

\section{CRITERIA:}

1. An occurrence reporting program is established which ensures that sufficient personnel are trained in root cause anaiysis techniques and are available.

2. The program shall ensure that those conducting investigations are independent of the cause of the unusual event.

3. The "lessons learned" which are developed as a result of the program implementation and root cause analysis shall be incorporated into the corrective action system to prevent recurrence.

4. The program should contain provisions to call in personnel with special expertise to assist in the occurrence investigation.

\begin{tabular}{|c|c|c|c|c|}
\hline \multirow{2}{*}{$\begin{array}{c}\text { SUBJECT/ACT IVITY } \\
\text { REQUIREMENT REFERENCE }\end{array}$} & \multirow{2}{*}{$\begin{array}{l}\text { EVIDENCE EXAMINED/ } \\
\text { PERSONNEL CONTACTED }\end{array}$} & \multirow[t]{2}{*}{ OBSERVATIONS/COMMENTS } & \multicolumn{2}{|c|}{ COMPLY } \\
\hline & & & YES & NO \\
\hline 1) Core rqmt. 8.12 & $\begin{array}{l}\text { OR RL-PHMC-SOLIDWASTE- } \\
\text { 1997-0002, } \\
\text { OR RL-PHMC-SOLID WASTE- } \\
\text { 1996-0002 } \\
\text { FM - Robert Giroir } \\
\text { OPN - Paul Crane } \\
\text { OPN - Michael Aichele } \\
\text { OPN - Jim Mitchell } \\
\text { ENV - Kent McDonald } \\
\text { RC - Brad Brannan } \\
\text { ENG - Mat Irwin }\end{array}$ & $\begin{array}{l}\text { There is an Occurrence Reporting Program \& } \\
\text { procedure. Procedure is in WHC-CM-5-34 } \\
\text { section 1.18. Charles Davis has } \\
\text { responsibility to prepare OR document. } \\
\text { Independence on the investigations is } \\
\text { achieved by QA, Rad Con, Ind. Safety, Ind. } \\
\text { Hygiene, and others with special expertise } \\
\text { called in on an as needed basis. Several } \\
\text { Occurrence Reports were reviewed. Most } \\
\text { pertinent are shown in the previous } \\
\text { column. Root Cause has been determined and } \\
\text { critiques have been held. There were } \\
\text { several others involving issues such as } \\
\text { tumbleweed contamination. The process } \\
\text { appears to be working well. }\end{array}$ & $X$ & \\
\hline
\end{tabular}




\section{RFSH PROJECT H-112 OPERATIONAL \\ READINESS REVIEW \\ EMERGENCY OPERATIONS DRILL PROGRAM \\ CORE REQUIREMENT 9.0}

CORE REQUIREMENT: 9.0 A routine and emergency operations drill program, including program records, has been established and implemented.

\section{CRITERIA:}

9.1 The drill program adequately plans, schedules, prepares, conducts, critiques, and documents drills.

APPROACH: $1,2,3,4,5$

KEY:

* 1= HNF-SD-WM-ISB-007, CWC Safety Basis.

* 2= WHC-SD-PRP-HA-010, Solid Waste Burial Ground/Centrai Waste Complex Hazard Assessment.

* 3= HFN-IP-0263-CWC, BEP for CWC.

* $4=$ HNF-PR-000424, Maintaining Facility Emergency Preparedness.

* 5= D0E-0223, Emergency Plan Implementing Procedure.

* $6=$ WHC-IP-GEN, Guidance and format for Building Emergency PIans.

* 7= WHC-IP-1018, Emergency Prep Program Plan.

* 8= WHC-CM-5-34, 1.5 Emergency/Operational Dril1 Program.

\begin{tabular}{|c|c|c|c|}
\hline CRITERIA & $\begin{array}{l}\text { REFERENCE } \\
\text { DOCUMENTS } \\
\end{array}$ & ASSESSMENT & ACTION ITEMS \\
\hline $\begin{array}{l}9.1 .1 \text { A program is } \\
\text { established and implemented } \\
\text { for the planning, } \\
\text { scheduling, preparation, } \\
\text { conduct, control, critique, } \\
\text { and documentation of } \\
\text { facility drills associated } \\
\text { with emergency response. } \\
\text { [D0E } 5500.3 \mathrm{~A} \text {, Section } \\
\text { 11.c.(12)(c); D0E/RL-94-02] }\end{array}$ & $\begin{array}{l}* 4 \\
* 8 \\
\text { Charles Davis } \\
\text { Paul Crane }\end{array}$ & $\begin{array}{l}\text { Items addressed } \\
\text { in WHC-CM-5-34, } \\
1.5 \text { Emergency/ } \\
\text { Operational Drill } \\
\text { Program. }\end{array}$ & $\begin{array}{l}\text { Meets Criteria. } \\
\text { No Action Required. }\end{array}$ \\
\hline
\end{tabular}




\begin{tabular}{|c|c|c|c|}
\hline $\begin{array}{l}9.1 .2 \text { Facility emergency } \\
\text { drilits are held in } \\
\text { accordance with the } \\
\text { schedule coordinated with } \\
\text { the Site Emergency } \\
\text { Management organization. } \\
\text { The drills are of a scope } \\
\text { and frequency to ensure } \\
\text { response capability in all } \\
\text { areas applicable to the } \\
\text { facility. [DOE 5500.3A, } \\
\text { Section 11.c.(12)(c); } \\
\text { DOE/RL-94-02] }\end{array}$ & $\begin{array}{l}* 4 \\
* 8 \\
\text { Charles Davis } \\
\text { Paul Crane }\end{array}$ & $\begin{array}{l}\text { Items addressed } \\
\text { in WHC-CM-5-34, } \\
1.5 \text { Emergency/ } \\
\text { Operational Dri } 11 \\
\text { Program. }\end{array}$ & $\begin{array}{l}\text { Meets Criteria } \\
\text { No Action Required. }\end{array}$ \\
\hline $\begin{array}{l}9.1 .3 \text { A Pre-Drill Report } \\
\text { is submitted at least two } \\
\text { weeks before the drill and } \\
\text { a Post-Drill Report is } \\
\text { submitted within two weeks } \\
\text { after completion of the } \\
\text { drill. [DOE/RL-94-02] }\end{array}$ & $\begin{array}{l}\text { * } 4 \\
\text { Charles Davis }\end{array}$ & $\begin{array}{l}\text { March Drill (Post } \\
\text { Drill) was not } \\
\text { submitted within } \\
\text { the two weeks. }\end{array}$ & $\begin{array}{l}\text { Submit drills and } \\
\text { schedule drills. } \\
\text { On schedule. }\end{array}$ \\
\hline
\end{tabular}




\begin{tabular}{|c|c|c|c|}
\hline $\begin{array}{l}9.1 .4 \text { Facility emergency } \\
\text { drills include simulated } \\
\text { events to test response to } \\
\text { radiological and hazardous } \\
\text { material monitoring } \\
\text { (spills, airborne releases, } \\
\text { sampling, etc.), fires, } \\
\text { loss of vital equipment, } \\
\text { facility evacuation and } \\
\text { accountability, and } \\
\text { security emergencies. } \\
\text { [D0E 5500.3A, Section } \\
\text { ll.c. (12) (c)] } \\
\text { NoTE: Facilities staffed } \\
\text { at all times conduct at } \\
\text { least one of the following } \\
\text { drills for each shift crew: } \\
\text { a. fire, evacuation, take } \\
\text { cover at l per year. } \\
\text { b. security, loss of } \\
\text { utilities, hazardous } \\
\text { material, contamination } \\
\text { spread, and criticality } \\
\text { at one per year for each } \\
\text { type in facilities where } \\
\text { there is a credible } \\
\text { potential for the } \\
\text { emergency. } \\
\text { c. seismic at one per year } \\
\text { (Plutonium Finishing } \\
\text { Plant only). } \\
\text { d. bomb threat at one per } \\
\text { year in hazardous } \\
\text { facilities with bomb } \\
\text { threat emergency action } \\
\text { levels. } \\
\text { With concurrence of the } \\
\text { area Site Emergency } \\
\text { Management representative, }\end{array}$ & $\begin{array}{l}\text { * } 8 \\
\text { Charles Davis } \\
\text { Paul Crane }\end{array}$ & $\begin{array}{l}\text { The Facility has } \\
\text { submitted and } \\
\text { approved a FY97 } \\
\text { dri11 schedule. }\end{array}$ & $\begin{array}{l}\text { Meets Criteria. } \\
\text { No Action Required. }\end{array}$ \\
\hline
\end{tabular}




\begin{tabular}{|c|c|c|c|}
\hline $\begin{array}{l}9.1 .5 \text { Simulated response } \\
\text { during facility drills is } \\
\text { minimized. Wherever } \\
\text { possible, the indications } \\
\text { from and the response to } \\
\text { the simulated event are the } \\
\text { same as if the event were } \\
\text { real [DOE 5500.3A, } \\
\text { Section } 11 . \mathrm{c.}(12) \text { (d)] }\end{array}$ & $\begin{array}{l}\text { * } 8 \\
\text { Charles Davis } \\
\text { Paul Crane }\end{array}$ & $\begin{array}{l}\text { Drills are not } \\
\text { currently to this } \\
\text { level of effort. } \\
\text { See attached } \\
\text { items. }\end{array}$ & See Attached items. \\
\hline $\begin{array}{l}9.1 .6 \text { Every dril] has a } \\
\text { formal critique with al1 } \\
\text { players, controllers, and } \\
\text { evaluators and the results } \\
\text { are documented. [DOE } \\
5500.3 \mathrm{~A} \text {, Section } \\
\text { 11.c. (12)(b)(6); DOE/RL-94- } \\
02 \text { ] }\end{array}$ & $\begin{array}{l}\text { * } 8 \\
\text { Charles Davis } \\
\text { Paul Crane }\end{array}$ & $\begin{array}{l}\text { A Post Driit } \\
\text { Critique is } \\
\text { performed as per } \\
\text { drill performed } \\
\text { for the ORR Team } \\
5 / 14 / 97 \text { and } \\
\text { previous dri11s. }\end{array}$ & Meets Criteria. \\
\hline $\begin{array}{l}9.1 .7 \text { A system of } \\
\text { deficiency identification, } \\
\text { evaluation, analysis, and } \\
\text { follow-up is established to } \\
\text { ensure weaknesses and } \\
\text { deficiencies are corrected. } \\
\text { [D0E } 5500.3 \mathrm{~A} \text {, Section } \\
\text { 11.c.(12)(e); DOE/RL-94-02] }\end{array}$ & $\begin{array}{l}\text { * } 8 \\
\text { Charles Davis } \\
\text { Paul Crane }\end{array}$ & $\begin{array}{l}\text { Less than } \\
\text { adequate critique } \\
\text { items are placed } \\
\text { on HATS. } \\
\text { observation of } \\
\text { Post Drill } \\
\text { Critique indicate } \\
\text { repetitive } \\
\text { problems example- } \\
\text { Reorder, } \\
\text { Communicator to } \\
\text { IC, Radiological } \\
\text { Work Practices } \\
\text { etc. }\end{array}$ & $\begin{array}{l}\text { Implement a SWM } \\
\text { required reading/ } \\
\text { all Personnel } \\
\text { Meeting etc. To } \\
\text { disseminate less } \\
\text { than adequate } \\
\text { practices to all } \\
\text { personnel. }\end{array}$ \\
\hline
\end{tabular}




\section{PHASE V STORAGE ORR APPRAISAL FORM}

\section{Management 11.1}

CORE REQUIREMENT: Functions, assignments, responsibilities, and reporting relationships are clearly defined, understood, and effectively implemented with 7 ine management responsible for control of safety.

APPROACH: Obtain organization charts, position descriptions, and procedures to establish that there exists, for individuals and departments, clear definitions and bounds of authority, accountability, responsibilities, and reporting relationships.

\section{CRITERIA:}

1. Policies/procedures exist defining the responsibility, authority, accountability, and reporting relationships of each management position, exempt position, non-exempt position, bargaining unit, and direct support personnel (e.g., Environmental Compliance, Fire Protection, Engineering, Maintenance, QA, Health Physics, Training, Industrial Hygienist, Industrial Safety, Nuclear Safety, Laboratories, Security, Records Management, Projects, Occurrence Reporting, Emergency Preparedness, etc.).

3. Department interface and bounds are clearly defined and understood.

4. Support group interface and bounds are clearly defined and understood.

5. Oversight interface and bounds are clearly defined and understood.

10. An adequate program exists for dissemination of generat information to employees regarding the facility.

11. Position descriptions are available.

12. Subcontractors understand their reporting relationships and responsibilities. Subcontractor interface and bounds are defined and understood. 


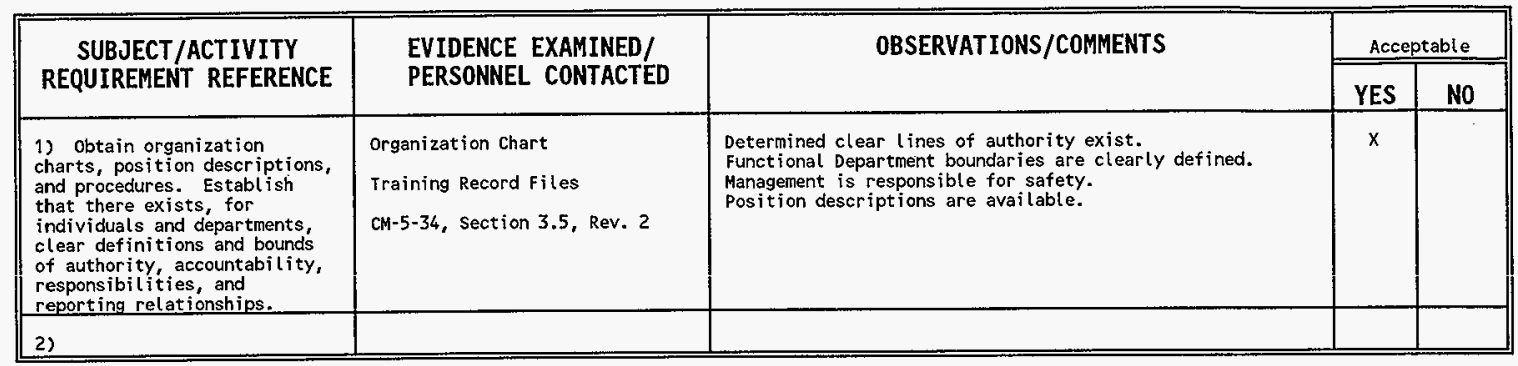




\section{PHASE V STORAGE ORR APPRAISAL FORM}

\section{Management 11.2}

CORE REQUIREMENT: Functions, assignments, responsibilities, and reporting relationships are clearly defined, understood, and effectively implemented with line management responsible for control of safety.

\section{APPROACH:}

2. Interview facility personnel to determine the adequacy of collateral duties, contractor/subcontractor interfaces and accountability, deiegation practices, management atititude and practices which foster or hinder cooperation and teamwork, effectiveness of information flow (timeliness, adequacy, emphasis on safety and environmental protection).

3. Interview managers to ensure there exists adequate access to DOE, regulators, and emergency organizations on matters of safety and environmental protection.

\section{CRITERIA:}

2. All personnel associated with the facility understand and implement their responsibilities, authority, accountability and reporting relationships.

3. Department interface and bounds are clearly defined and understood.

4. Support group interface and bounds are clearly defined and understood.

5. oversight interface and bounds are clearly defined and understood.

6. Managers have appropriate access to DOE, regulators, and emergency organizations on matters of safety and environmental protection.

7. Line organizations are unencumbered by excessive duties or significant duties unrelated to the day-today operation.

8. Managers encourage and effectively foster teamwork and cooperation among interfacing organizations.

9. Directives and other management information flow quickly and accurately through the management chain and other formal channels of communication. 
12. Subcontractors understand their reporting relationships and responsibilities. Subcontractor interface and bounds are defined and understood.

\begin{tabular}{|c|c|c|c|c|}
\hline \multirow{2}{*}{$\begin{array}{l}\text { SUBJECT./ACTIVITY } \\
\text { REQUIRENENT REFERENCE }\end{array}$} & \multirow{2}{*}{$\begin{array}{l}\text { EVIDENCE EXAMINED/ } \\
\text { PERSONNEL CONTACTED }\end{array}$} & \multirow[t]{2}{*}{ OBSERVATIONS/COMMENTS } & \multicolumn{2}{|c|}{ ACCEPTABLE } \\
\hline & & & YES & NO \\
\hline $\begin{array}{l}\text { 1) Interview facility } \\
\text { personnel to determine the } \\
\text { adequacy of collateral duties, } \\
\text { contractor/ subcontractor } \\
\text { interfaces and accountability, } \\
\text { delegation practices, } \\
\text { management attitude and } \\
\text { practices which foster or } \\
\text { hinder cooperation and } \\
\text { teamwork, effectiveness of } \\
\text { information flow (timel iness, } \\
\text { adequacy, emphasis on safety } \\
\text { and environmental protection). }\end{array}$ & $\begin{array}{l}\text { interviews conducted: } \\
\text { G. Mickle } \\
\text { R. Robbins } \\
\text { R. Whitiock } \\
\text { J. Mitchell } \\
\text { D. Pyzel } \\
\text { S. Stitt }\end{array}$ & $\begin{array}{l}\text { Determined that personnel understood how their assignment } \\
\text { contributed to safety within CWC. } \\
\text { Information flow within the organization is satisfactory } \\
\text { and timely"-personnel generally falt we!l-informed. } \\
\text { Management attitudes and practices foster cooperation and } \\
\text { team work. } \\
\text { Departmental interfaces work well. }\end{array}$ & $x$ & \\
\hline $\begin{array}{l}\text { Describe your primary } \\
\text { responsibilities. }\end{array}$ & 11 & $\mathrm{~N} / \mathrm{A}$ & $x$ & \\
\hline $\begin{array}{l}\text { Describe how these } \\
\text { responsibilities sustain or } \\
\text { improve safety in the } \\
\text { operations taking place. }\end{array}$ & " & $\begin{array}{l}\text { Personnel interviewed understood how they fit into overall } \\
\text { safety of the facility. }\end{array}$ & $x$ & \\
\hline $\begin{array}{l}\text { How do contractor/ } \\
\text { subcontractor interfaces and } \\
\text { accountability affect a safe } \\
\text { working environment? }\end{array}$ & $"$ & Discussions centered around accountability for safety. & $\mathrm{x}$ & \\
\hline $\begin{array}{l}\text { Describe how delegating work } \\
\text { to others affects your ability } \\
\text { to work safely. }\end{array}$ & $" 1$ & N/A & & \\
\hline $\begin{array}{l}\text { How do management atti tudes } \\
\text { and practices foster or hinder } \\
\text { cooperation and teamwork in } \\
\text { the CWC? }\end{array}$ & 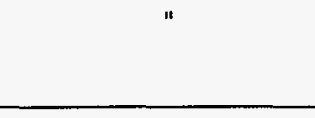 & $\begin{array}{l}\text { Management is encouraging, fosters teamwork. } \\
\text { Positive, keeps things in perspective. } \\
\text { Teamwork, rotating assignments. } \\
\text { Good cooperation. } \\
\text { Help establish priorities }\end{array}$ & $x$ & \\
\hline $\begin{array}{l}\text { Is the flow of information } \\
\text { effective (is it timely, is it } \\
\text { adequate, does it help or } \\
\text { hinder personnel safety and } \\
\text { environmental protection)? }\end{array}$ & " & $\begin{array}{l}\text { Within a subcontractor organization -- good. } \\
\text { FDH and DOE down to Sub organizations -- not as good. } \\
\text { The flow helps work performance. }\end{array}$ & $x$ & \\
\hline
\end{tabular}




\begin{tabular}{|c|c|c|c|}
\hline $\begin{array}{l}\text { 2) Interview managers to } \\
\text { ensure there exists adequate } \\
\text { access to DOE, regulators, and } \\
\text { emergency organizations on } \\
\text { matters of safety and } \\
\text { environmental protection. }\end{array}$ & $\begin{array}{l}\text { Interviews conducted: } \\
\text { G. Mickle } \\
\text { R. Robbins } \\
\text { R. Whitlock } \\
\text { J. Mitchell } \\
\text { D. Pyzel } \\
\text { S. Stitt } \\
\end{array}$ & $\begin{array}{l}\text { Where required, access is available through appropriate } \\
\text { technical specialists and Managers. }\end{array}$ & $\mathrm{x}$ \\
\hline $\begin{array}{l}\text { What is your role and } \\
\text { responsibil ity in ensuring a } \\
\text { safe working environment? }\end{array}$ & \# & $\begin{array}{l}\text { Personnel interviewed were able to describe their role and } \\
\text { responsibility in ensuring a safe working environment. }\end{array}$ & $\mathrm{x}$ \\
\hline $\begin{array}{l}\text { How can operations in the CNC } \\
\text { af fect environmental } \\
\text { protection? }\end{array}$ & " & $\begin{array}{l}\text { Personnel interviewed could describe the potential negative } \\
\text { impact of cWC operations on the environment. }\end{array}$ & $x$ \\
\hline $\begin{array}{l}\text { What is your path for } \\
\text { obtaining assistance or } \\
\text { information from DOE, } \\
\text { regulators, and site emergency } \\
\text { organizations? }\end{array}$ & " & Path for obtaining assistance is understood. & $\mathrm{x}$ \\
\hline $\begin{array}{l}\text { Do you receive adequate } \\
\text { assistance from DOE and site } \\
\text { emergency organizations? }\end{array}$ & $"$ & When required, assistance is satisfactory. & $\mathrm{x}$ \\
\hline
\end{tabular}


Core Requirement 12.0 The implementation status for DOE Order 5480.19. conduct of operations requirements for DOE facilities, is adequate for operations.

WHC-CM-5-34, Sec. 3.0, 3.7, Shift Routine and Operating Practices

\begin{tabular}{|c|c|c|c|c|}
\hline \multirow{2}{*}{$\begin{array}{c}\text { SUBJECT/ACTIVITY } \\
\text { REQUIREMENT REFERENCE }\end{array}$} & \multirow{2}{*}{$\begin{array}{l}\text { EVIDENCE EXANINED/ } \\
\text { PERSONNEL CONTACTED }\end{array}$} & \multirow{2}{*}{ OBSERVATIONS/COMMENTS } & \multicolumn{2}{|c|}{ COMPLY } \\
\hline & & & YES & NO \\
\hline 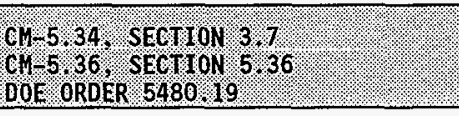 & (1. & (2. & & . \\
\hline $\begin{array}{l}\text { 1. Are operator rounds } \\
\text { periodically monitored by } \\
\text { supervisory personnel to ensure } \\
\text { that comprehensive tours } \\
\text { continue to be conducted? } \\
5480.19 \text {, Chapter II, C. } 4\end{array}$ & $\begin{array}{l}5 \text {-34, Section } 3.7 \text {, para. } 4.6 \\
\text { requires shift manager/team } \\
\text { leader perform this } \\
\text { surveillance monthly and } 10 \mathrm{~g} \text { in } \\
\text { Facility logbook. } \\
\text { Interviewed Team Leader, Mike } \\
\text { Aichele } \\
\text { Discussed with Operations } \\
\text { Manager, Paul Crane }\end{array}$ & $\begin{array}{l}\text { The Team Leader for CWC indicated } \\
\text { he was not aware of this } \\
\text { requirement nor was he performing } \\
\text { the logging action. However, he } \\
\text { did work in the field with the } \\
\text { operators each day and considered } \\
\text { the surveillance was being } \\
\text { performed. }\end{array}$ & & $x$ \\
\hline $\begin{array}{l}\text { 2. Are alarm light bulbs \& } \\
\text { annunciators checked at least } \\
\text { once per shift. Are alternate } \\
\text { inspection schedules approved by } \\
\text { the Operations Supervisor or } \\
\text { Manager? } \\
5480.19 \text {, Chapter II, C. } 3\end{array}$ & $\begin{array}{l}\text { Included in 5-34, Section } 3.7 \text {, } \\
\text { para. } 4.5 \\
\text { Surveillance Operator Bruce } \\
\text { Rogers. } \\
\text { Alarm lights are not } \\
\text { specifically called out on } \\
\text { round sheets. However, } \\
\text { operators check all panels for } \\
\text { alarms. In CWC, alarms are } \\
\text { fire protection and alarm at } \\
\text { the Fire Station. }\end{array}$ & No deficiencies noted & $x$ & \\
\hline
\end{tabular}




\begin{tabular}{|c|c|c|c|c|}
\hline \multirow{2}{*}{$\begin{array}{c}\text { SUBJECT/ACTIVITY } \\
\text { REQUIREMENT REFERENCE }\end{array}$} & \multirow{2}{*}{$\begin{array}{l}\text { EVIDENCE EXAMINED/ } \\
\text { PERSONNEL CONTACTED }\end{array}$} & \multirow{2}{*}{ OBSERVATIONS/COMMENTS } & \multicolumn{2}{|c|}{ COMPLY } \\
\hline & & & YES & NO \\
\hline $\begin{array}{l}\text { 3. Are tours by operations } \\
\text { personnel of sufficient detail } \\
\text { to ensure that the status of } \\
\text { equipment is known? } \\
5480.19 \text {, Chapter II, C. } 3\end{array}$ & $\begin{array}{l}\text { Included in } 5-34 \text {, Section } 3.7 \\
\text { para. } 4.5 \\
\text { Tour with survei17ance operator } \\
\text { B Rogers on } 5 / 12 / 97\end{array}$ & $\begin{array}{l}\text { The surveillance sheets for the } \\
\text { CWC procedure provide sufficient } \\
\text { detail to ensure the status of } \\
\text { equipment. However, some } \\
\text { deficiencies related to fire } \\
\text { systems have been outstanding for } \\
\text { several months. Specificaily, } \\
\text { - One fire system valve position } \\
\text { indicator has been noted as being } \\
\text { inoperative for } \\
\text {-Some PIVs are not Tabeled }\end{array}$ & & \\
\hline $\begin{array}{l}\text { 4. Do data sheets include } \\
\text { maximum/minimum values for } \\
\text { equipment parameters? } \\
5480.19 \text {, Chapter II, C. } 4\end{array}$ & $\begin{array}{l}\text { Included in } 5-34 \text {, Section } 3.7 \text {, } \\
\text { para. } 4.6 \\
\text { Surveillance sheets for the CWC } \\
043 \text { procedure }\end{array}$ & $\begin{array}{l}\text { Surveillance sheets include max } \\
\text { and min values for equipment } \\
\text { parameters. }\end{array}$ & $x$ & \\
\hline $\begin{array}{l}\text { 5. Are parameters outside } \\
\text { specified maximum/minimum red } \\
\text { circled, reported to operations } \\
\text { team leader, and noted in the } \\
\text { narrative section or reference } \\
\text { made to the explanation in the } \\
\text { facility log book? } \\
5480.19 \text {, Chapter II, C.4 }\end{array}$ & $\begin{array}{l}\text { Included in 5-34, Section } 3.7 \text {, } \\
\text { para. } 4.6 \\
\text { Mike Aichele - Team Leader } \\
\text { Bruce Rogers - Operator } \\
\text { Steve Kenne } 71 \text { - Operator } \\
\text { Paul Crane - Operations Manager }\end{array}$ & $\begin{array}{l}\text { 0perators do not red circle out of } \\
\text { specification parameters as } \\
\text { required by the 5-34 Manual. } \\
\text { However, they do report out of } \\
\text { spec readings to the Ops Team } \\
\text { Leader and the out of } \\
\text { specification condition is logged } \\
\text { in the facility log book. } \\
\text { The Operations Manager indicated } \\
\text { action would be taken to have } \\
\text { operators red circle out of } \\
\text { specification parameters. }\end{array}$ & & $x$ \\
\hline $\begin{array}{l}\text { 6. Are security keys controlled } \\
\text { by the responsible facility } \\
\text { manager/team leader? }\end{array}$ & $\begin{array}{l}\text { Included in } 5-34 \text {, Section } 3.7 \text {, } \\
\text { para. } 4.10 \\
\text { Mike Aichele }\end{array}$ & $\begin{array}{l}\text { Operators and team leaders have } \\
\text { keys to the CWC buildings and they } \\
\text { are controlled. }\end{array}$ & $x$ & \\
\hline
\end{tabular}




\begin{tabular}{|c|c|c|c|c|}
\hline \multirow{2}{*}{$\begin{array}{c}\text { SUBJECT/ACTIVITY } \\
\text { REQUIREMENT REFERENCE }\end{array}$} & \multirow{2}{*}{$\begin{array}{l}\text { EVIDENCE EXAMINED/ } \\
\text { PERSONNEL CONTACTED }\end{array}$} & \multirow{2}{*}{ OBSERVATIONS/COMMENTS } & \multicolumn{2}{|c|}{ COMPLY } \\
\hline & & & YES & No \\
\hline $\begin{array}{l}\text { 7. Does the facility operating } \\
\text { base contain current copies of } \\
\text { IOSRs, Operating Procedures and } \\
\text { the Emergency Plan? } \\
5480.19 \text {, Chapter II, C. } 10\end{array}$ & $\begin{array}{l}\text { Included in } 5-34 \text {, Section } 3.7 \text {, } \\
\text { para. } 4.12 \text { requires IOSRs, 5- } \\
36 \text {, Chapters } 1-10,4-40,5-34 \\
\text { and BEP. } \\
\text { Mike Aichele - Team Leader }\end{array}$ & $\begin{array}{l}\text { The facility operating base in MO- } \\
720 \text { has the required documents. } \\
\text { Supporting documents are also } \\
\text { readily available in M0-720. }\end{array}$ & $x$ & \\
\hline $\begin{array}{l}\text { 8. Are log errors corrected } \\
\text { properly? }\end{array}$ & $\begin{array}{l}\text { Included in CM-5-34 Section } \\
3.7 \text {, para. } 4.17 \\
\text { Reviewed facility narrative } 10 \mathrm{~g} \\
\text { and operator round sheets. }\end{array}$ & $\begin{array}{l}\text { Log maintenance practices meet an } \\
\text { acceptable standard. } \\
\text { The format of the Facility Logbook } \\
\text { in M0- } 288 \text { makes it very easy to } \\
\text { follow during review. }\end{array}$ & $x$ & \\
\hline $\begin{array}{l}\text { 9. Are drawings used for } \\
\text { operational decisions current } \\
\text { and contain the letters "FV?" }\end{array}$ & $\begin{array}{l}\text { Included in CM-5-34 Section } \\
3.7 \text {, para. } 4.18 \\
\text { Mike Aichele - Team Leader } \\
\text { Jim Mitchel1 - Engineer }\end{array}$ & $\begin{array}{l}\text { Operations does not maintain } \\
\text { drawings at their control centers } \\
\text { and instead relies on engineering } \\
\text { to maintain drawings up to date } \\
\text { and request support when needed. } \\
\text { Operations at the cWC are not } \\
\text { facility drawing dependent; } \\
\text { therefore, relying on engineering } \\
\text { for drawings is considered } \\
\text { acceptable. }\end{array}$ & $x$ & \\
\hline $\begin{array}{l}\text { 10. Are daily surveillance tour } \\
\text { deficiencies followed up for } \\
\text { corrective action? }\end{array}$ & $\begin{array}{l}\text { Inciuded in CM-5-34 Section } \\
3.7 \text {, para. } 4.6 \\
\text { Observation of Surveillance } \\
\text { rounds }\end{array}$ & $\begin{array}{l}\text { Items are tracked and worked using } \\
\text { an Open Item list. Some items } \\
\text { have been open for a significant } \\
\text { amount of time (several months). }\end{array}$ & $x$ & \\
\hline
\end{tabular}




\begin{tabular}{|c|c|c|c|c|}
\hline \multirow{2}{*}{$\begin{array}{c}\text { SUBJECT/ACTIVITY } \\
\text { REQUIREMENT REFERENCE }\end{array}$} & \multirow{2}{*}{$\begin{array}{l}\text { EVIDENCE EXAMINED/ } \\
\text { PERSONNEL CONTACTED }\end{array}$} & \multirow{2}{*}{ OBSERVATIONS/COMMENTS } & \multicolumn{2}{|c|}{ COMPLY } \\
\hline & & & YES & No \\
\hline $\begin{array}{l}\text { 12. Are surveillance data } \\
\text { sheets being used on the daily } \\
\text { tours maintained up to date? }\end{array}$ & $\begin{array}{l}\text { Surveillance sheets are printed } \\
\text { directly from the I drive each } \\
\text { Monday for the week. This } \\
\text { ensures the most recent copies } \\
\text { are used. } \\
\text { Mike Aichele - Team Leader } \\
\text { Bruce Rogers - Operator }\end{array}$ & $\begin{array}{l}\text { Surveillance sheets in use on } \\
5 / 12 / 97 \text { were the most recent } \\
\text { version. } \\
\text { Maintenance of procedures through } \\
\text { the I drive is an excellent cost } \\
\text { saving practice and ensures } \\
\text { personnel have the most recent } \\
\text { revision. }\end{array}$ & $x$ & \\
\hline $\begin{array}{l}\text { 13. Are housekeeping } \\
\text { deficiencies noted on } \\
\text { surveillance tours? }\end{array}$ & $\begin{array}{l}\text { Included in } \mathrm{CM}-5-34 \text { Section } \\
3.7 \text {, para. } 4.5 \\
\text { Operator round sheets and } \\
\text { actual operator tours. }\end{array}$ & $\begin{array}{l}\text { Round sheets do require } \\
\text { housekeeping checks and the } \\
\text { operator (Bruce Rogers) was very } \\
\text { conscientious in this regard. }\end{array}$ & $x$ & \\
\hline
\end{tabular}

3.9, Communication

\begin{tabular}{|c|c|c|c|c|}
\hline \multirow{2}{*}{$\begin{array}{c}\text { SUBJECT/ACTIVITY } \\
\text { REQUIREMENT REFERENCE }\end{array}$} & \multirow{2}{*}{$\begin{array}{l}\text { EVIDENCE EXAMINED/ } \\
\text { PERSONNEL CONTACTED }\end{array}$} & \multirow{2}{*}{ OBSERVATIONS/COMMENTS } & \multicolumn{2}{|c|}{ COMPLY } \\
\hline & & & YES & NO \\
\hline 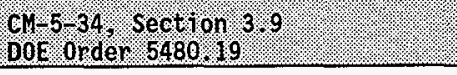 & & & & \\
\hline $\begin{array}{l}\text { 1. Are communications conducted } \\
\text { in a professional manner? }\end{array}$ & $\begin{array}{l}\text { Included in } \mathrm{CM}-5-34 \text { Section } \\
3.9 \text {, para. } 4.1 .2 \\
\text { Observed shift briefing on } \\
5 / 12 / 97 \text {. }\end{array}$ & $\begin{array}{l}\text { Communications by the Team Leader } \\
\text { were clear. A status board is } \\
\text { used for job assignment which } \\
\text { provides the communications } \\
\text { operator (scribe) with a listing } \\
\text { of who is doing what work. } \\
\text { No deficiencies noted. }\end{array}$ & $x$ & \\
\hline
\end{tabular}




\begin{tabular}{|c|c|c|c|c|}
\hline \multirow{2}{*}{$\begin{array}{c}\text { SUBJECT/ACTIVITY } \\
\text { REQUIREMENT REFERENCE }\end{array}$} & \multirow{2}{*}{$\begin{array}{l}\text { EVIDENCE EXAMINED/ } \\
\text { PERSONNEL CONTACTED }\end{array}$} & \multirow{2}{*}{ OBSERVAT IONS/COMMENTS } & \multicolumn{2}{|c|}{ COMPLY } \\
\hline & & & YES & No \\
\hline $\begin{array}{l}\text { 2. Are "repeat backs" given } \\
\text { when remote communication } \\
\text { instructions involve the } \\
\text { operation of system equipment? } \\
5480.19 \text {, Chapter III, C. } 6\end{array}$ & $\begin{array}{l}\text { Included in CM-5-34 Section } \\
3.9 \text {, para. } 5.1 .13 \\
\text { No specific equipment operating } \\
\text { instructions were observed for } \\
\text { this review. }\end{array}$ & Not Observed & NA & NA \\
\hline $\begin{array}{l}\text { 3. Are methods in place to } \\
\text { ensure facility personnel are } \\
\text { promptly alerted to facility } \\
\text { emergencies? } \\
5480.19 \text {, Chapter IV, C.I }\end{array}$ & $\begin{array}{l}\text { Included in CM-5-34 Section } \\
3.9 \text {, para. } 5.3 \\
\text { Mike Aichele - Team Leader } \\
\text { Steve Kennelly - Operator } \\
\text { Bruce Rogers - Operator }\end{array}$ & $\begin{array}{l}\text { General announcing, radios and } \\
\text { beepers are available and used for } \\
\text { notifications of problems. } \\
\text { However, these are often not } \\
\text { functional within the metal } \\
\text { buildings. The CWC Team Leader } \\
\text { indicated the general announcing } \\
\text { circuit was being deactivated } \\
\text { because it was not very good and } \\
\text { expensive to maintain. The } 200 \\
\text { West emergency sirens are } \\
\text { operational. However, it is } \\
\text { questionable as to whether or not } \\
\text { they could be heard inside the } \\
\text { buildings with a forklift } \\
\text { operating and the doors closed. } \\
\text { Throughout the review, the Scribe } \\
\text { had difficulty with communications } \\
\text { utilizing radios, pagers, and } \\
\text { phones within the buildings. It } \\
\text { is the teams suggestion that Solid } \\
\text { Waste research obtaining repeaters } \\
\text { and their own channel for the } \\
\text { radios. } \\
\text { (Note: To save money Purex may } \\
\text { have some excess equipment that } \\
\text { can be used.) }\end{array}$ & & $x$ \\
\hline
\end{tabular}




\begin{tabular}{||l|l|l|l|l}
\hline \multicolumn{1}{|c|}{$\begin{array}{c}\text { SUBJECT/ACTIVITY } \\
\text { REQUIREMENT REFERENCE }\end{array}$} & \multicolumn{1}{c|}{$\begin{array}{c}\text { EVIDENCE EXAMINED/ } \\
\text { PERSONNEL CONTACTED }\end{array}$} & COMPLY \\
\hline $\begin{array}{l}\text { 4. Does communications } \\
\text { equipment support efficient } \\
\text { communications? } \\
5480.19, \text { Chapter III, C.4 }\end{array}$ & Same as above & Same as above & YES & NO \\
\hline
\end{tabular}

WHC-CM-5-34, Sec. $3,0,3,10$, on the Job Training

(Covered under core requirements 2. \& 3)

\begin{tabular}{|c|c|c|c|c|}
\hline \multirow{2}{*}{$\begin{array}{c}\text { SUBJECT/ACTIVITY } \\
\text { REQUIREMENT REFERENCE }\end{array}$} & \multirow{2}{*}{$\begin{array}{l}\text { EVIDENCE EXAMINED/ } \\
\text { PERSONNEL CONTACTED }\end{array}$} & \multirow{2}{*}{ OBSERVATIONS/COMMENTS } & \multicolumn{2}{|c|}{ COMPLY } \\
\hline & & & YES & NO \\
\hline 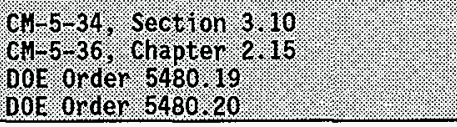 & (2) & (1. & & \\
\hline $\begin{array}{l}\text { 1. Are target dates for } \\
\text { trainees to reach milestones and } \\
\text { complete training assigned? }\end{array}$ & $\begin{array}{l}\text { Included in CM-5-34 Section } \\
3.1 \text {, para. } 4.2 \\
\text { Mike Aichele - Team Leader } \\
\text { Actions for training in this } \\
\text { area were reviewed under core } \\
\text { requirement } 2\end{array}$ & $\begin{array}{l}\text { 0JT was reviewed under core } \\
\text { requirement } 2 \text {. However, } \\
\text { interviews with the Team Leader } \\
\text { found he was knowledgeable of OJT } \\
\text { training requirements. }\end{array}$ & & \\
\hline $\begin{array}{l}\text { 2. Is OJT conducted by } \\
\text { individuals qualified in the } \\
\text { operation of the facility with } \\
\text { the appropriate } 0 J T \text { instructor } \\
\text { training requirements completed? }\end{array}$ & $\begin{array}{l}\text { Included in } \mathrm{CM}-5-34 \text { Section } \\
3.10 \text {, para. } 5.2 \\
\text { Actions for training in this } \\
\text { area were covered under reviews } \\
\text { for core requirement } 2\end{array}$ & Not Observed & & \\
\hline
\end{tabular}




\begin{tabular}{|c|c|c|c|c|}
\hline \multirow{2}{*}{$\begin{array}{c}\text { SUBJECT/ACTIVITY } \\
\text { REQUIREMENT REFERENCE }\end{array}$} & \multirow{2}{*}{$\begin{array}{l}\text { EVIDENCE EXAMINED/ } \\
\text { PERSONNEL CONTACTED }\end{array}$} & \multirow{2}{*}{ OBSERVATIONS/COMMENTS } & \multicolumn{2}{|c|}{ COMPLY } \\
\hline & & & YES & No \\
\hline $\begin{array}{l}\text { 3. Does 0JT include the } \\
\text { following four elements? } \\
\text { objective, Standards, } \\
\text { Evaluation, Documentation. }\end{array}$ & $\begin{array}{l}\text { Included in } \mathrm{CM}-5-34 \text { Section } \\
3.10 \text {, para. } 5.8 \\
\text { Actions for training in this } \\
\text { area were reviewed under core } \\
\text { requirement } 2 \text {. }\end{array}$ & Not Observed & & \\
\hline
\end{tabular}

WHC-CM-5-34, Sec. 3.0, 3.13, Control of Equipment and system Status

\begin{tabular}{|c|c|c|c|c|}
\hline \multirow{2}{*}{$\begin{array}{l}\text { SUBJECT/ACTIVITY } \\
\text { REQUIREMENT REFERENCE }\end{array}$} & \multirow{2}{*}{$\begin{array}{l}\text { EVIDENCE EXAMINED/PERSONNEL } \\
\text { CONTACTED }\end{array}$} & \multirow{2}{*}{ OBSERVATIONS/COMMENTS } & \multicolumn{2}{|c|}{ COMPLY } \\
\hline & & & YES & No \\
\hline 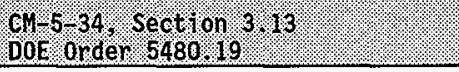 & & & & \\
\hline $\begin{array}{l}\text { 1. Are changes in the status of } \\
\text { facility equipment and systems } \\
\text { documented in the Facility } \\
\text { Logbooks? }\end{array}$ & $\begin{array}{l}\text { Included in CM-5-34, Section } \\
3.13,4.1 \\
\text { Mike Aichele - Team Leader } \\
\text { Steve Kennelly - Operator } \\
\text { Reviewed facility logbook in } \\
\text { M0-288 for the months of April } \\
\text { and May. }\end{array}$ & $\begin{array}{l}\text { The facility logbook provides a } \\
\text { record of facility operations and } \\
\text { status changes. }\end{array}$ & $x$ & \\
\hline $\begin{array}{l}\text { 2. At the beginning of each day } \\
\text { shift, do Facility Logbooks } \\
\text { reflect initial facility } \\
\text { conditions? }\end{array}$ & $\begin{array}{l}\text { Included in } C M-5-34 \text {, Section } \\
3.13,4.3 \\
\text { Reviewed facility operations } \\
\text { log in M0-288 for the months of } \\
\text { April and May. }\end{array}$ & $\begin{array}{l}\text { The facility logbook adequately } \\
\text { describes facility conditions at } \\
\text { the beginning of each day. }\end{array}$ & $x$ & \\
\hline
\end{tabular}




\begin{tabular}{|c|c|c|c|c|}
\hline \multirow{2}{*}{$\begin{array}{l}\text { SUBJECT/ACTIVITY } \\
\text { REQUIREMENT REFERENCE }\end{array}$} & \multirow{2}{*}{$\begin{array}{l}\text { EVIDENCE EXAMINED/PERSONNEL } \\
\text { CONTACTED }\end{array}$} & \multirow{2}{*}{ OBSERVATIONS/COMMENTS } & \multicolumn{2}{|c|}{ COMPLY } \\
\hline & & & YES & No \\
\hline $\begin{array}{l}\text { 3. Is equipment tested after } \\
\text { maintenance to demonstrate it is } \\
\text { capable of performing the } \\
\text { intended function? }\end{array}$ & $\begin{array}{l}\text { Included in CM-5-34, Section } \\
3.13,4.6 \\
\text { Facility Logbook in M0- } 288 \\
\text { Reviewed } 20 \text { closed work } \\
\text { packages for post-maintenance } \\
\text { testing. }\end{array}$ & $\begin{array}{l}\text { Completion of maintenance actions } \\
\text { are recorded in the facility log. } \\
\text { However, there was no record of } \\
\text { retest. Based on the entries none } \\
\text { of the items suggested a retest } \\
\text { was required. } \\
\text { Based on the information available } \\
\text { for this review, most work in the } \\
\text { facilities is preventive } \\
\text { maintenance with no retest } \\
\text { required. } \\
\text { The preventive maintenance work } \\
\text { packages do have equipment return } \\
\text { to service requirements. }\end{array}$ & $x$ & \\
\hline $\begin{array}{l}\text { 4. Is alarm status noted in } \\
\text { Facility Logbooks? }\end{array}$ & $\begin{array}{l}\text { Included in CM-5-34, Section } \\
3.13,4.7 \\
\text { Facility Logbook in Mo-288 } \\
\text { Facility tour on } 5 / 14 / 97\end{array}$ & $\begin{array}{l}\text { No locked in alarms were noted } \\
\text { during this review; however, the } \\
\text { facility logbook did include } \\
\text { entries for receipt and clearing } \\
\text { of alarms. }\end{array}$ & $X$ & \\
\hline
\end{tabular}

WHC-CM-5-34, Sec. 3.0, 3.14, Lockout and Tagout

\begin{tabular}{|c|c|c|c|c|}
\hline \multirow{2}{*}{$\begin{array}{c}\text { SUBJECT/ACTIVITY } \\
\text { REQUIREMENT REFERENCE }\end{array}$} & \multirow{2}{*}{$\begin{array}{l}\text { EVIDENCE EXAMINED/ } \\
\text { PERSONNEL CONTACTED }\end{array}$} & \multirow[b]{2}{*}{ OBSERVATIONS/COMMENTS } & \multicolumn{2}{|c|}{ COMPLY } \\
\hline & & & YES & NO \\
\hline 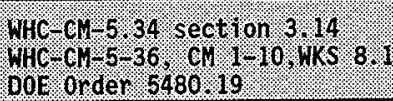 & & & & 4. \\
\hline
\end{tabular}




\begin{tabular}{|c|c|c|c|c|}
\hline \multirow{2}{*}{$\begin{array}{c}\text { SUBJECT/ACTIVITY } \\
\text { REQUIRENENT REFERENCE }\end{array}$} & \multirow{2}{*}{$\begin{array}{l}\text { EVIDENCE EXAMINED/ } \\
\text { PERSONNEL CONTACTED }\end{array}$} & \multirow{2}{*}{ OBSERVATIONS/COMMENTS } & \multicolumn{2}{|c|}{ COMPLY } \\
\hline & & & YES & NO \\
\hline $\begin{array}{l}\text { 1. Are primary \& alternate Lock } \\
\text { and Tag Administrators } \\
\text { designated in writing? } \\
\text { CM-5-34(3.14/4.0.1) }\end{array}$ & $\begin{array}{l}\text { Beth Wright - Backup L\&T Admin } \\
\text { Brad Graff - Electrical Cog } \\
\text { Rich C1inton - CWC Cog } \\
\text { Section } 3.14 \text { of the } 5-34 \text { Manual } \\
\text { directed the use of Waste } \\
\text { Management Operations } \\
\text { Administration procedure RFSH- } \\
200\end{array}$ & $\begin{array}{l}\text { The Lock and Tag logbook includes } \\
\text { a listing of L\&T Administrators. } \\
\text { Personnel contacted were not } \\
\text { familiar with the RFSH } 200 \\
\text { procedure and were not using this } \\
\text { as the controlling document for L } \\
\& \text { T operations. They instead were } \\
\text { using WHC-CM-1-5, Section } 9.1 \text { as } \\
\text { the controlling procedure: These } \\
\text { procedures are the same in } \\
\text { content. }\end{array}$ & $X$ & \\
\hline $\begin{array}{l}\text { 2. Have employees completed } \\
\text { Lock/tag training? } \\
\text { CM-5-34(3.14/4.1) }\end{array}$ & Training records & $\begin{array}{l}\text { Records indicate personnel have } \\
\text { been trained on the new sitewide } \\
\text { lock and tag procedure. }\end{array}$ & $x$ & \\
\hline $\begin{array}{l}\text { 3. Are safe condition checks } \\
\text { approved by a technical reviewer } \\
\text { and the administrator? } \\
\mathrm{CM}-5-34(3.14 / 5.2)\end{array}$ & $\begin{array}{l}\text { Reviewed } 20 \text { completed work } \\
\text { packages and there was no } \\
\text { evidence of this action. } \\
\text { However, there is no specific } \\
\text { requirement for this since } \\
\text { section } 3.14 \text { was canceled. }\end{array}$ & $\begin{array}{l}\text { Work packages that required locks } \\
\text { and tags included copies of tagout } \\
\text { sheets which indicated safe } \\
\text { condition checks were performed. }\end{array}$ & $x$ & \\
\hline
\end{tabular}




\begin{tabular}{|c|c|c|c|c|}
\hline \multirow{2}{*}{$\begin{array}{c}\text { SUBJECT/ACTIVITY } \\
\text { REQUIRENENT REFERENCE }\end{array}$} & \multirow{2}{*}{$\begin{array}{l}\text { EVIDENCE EXAMINED/ } \\
\text { PERSONNEL CONTACTED }\end{array}$} & \multirow{2}{*}{ OBSERVATIONS/COMMENTS } & \multicolumn{2}{|c|}{ COMPLY } \\
\hline & & & YES & No \\
\hline $\begin{array}{l}\text { 4. Are technical reviews } \\
\text { performed by cognizant } \\
\text { engineers, using approved } \\
\text { sketches or drawings showing the } \\
\text { lockout points? } \\
\text { CM-5-34(3.14/5.3) }\end{array}$ & $\begin{array}{l}\text { Brad Graff - Electrical Cog } \\
\text { Rich Clinton - CWC Cog } \\
\text { Interviews of cognizant } \\
\text { engineers indicated this was } \\
\text { the standard practice as well } \\
\text { as field walkdowns. }\end{array}$ & $\begin{array}{l}\text { Reviews of the RFSH-200 procedure } \\
\text { found it does not specify how and } \\
\text { where the authorized worker's } \\
\text { lockout/tagout is applied as } \\
\text { required by DOE-RL-SOD-INST- } \\
\text { L\&T.001 Rev 1, Section } 4 \text {.1 nor are } \\
\text { there CWC specific procedures } \\
\text { which include this requirement. } \\
\text { Interviews with personnel found } \\
\text { discrepancies in awareness of } \\
\text { responsibility for ensuring the } 8 \\
\text { criteria for using an Authorized } \\
\text { Worker's lockout/tagout by itself. } \\
\text {-One cognizant engineer indicated } \\
\text { it was his responsibility. } \\
\text { However, could not explain how the } \\
\text { determination was made on whether } \\
\text { or not there had been previous } \\
\text { accidents related to unexpected } \\
\text { activation or re-energization of } \\
\text { the machine or equipment. } \\
\text {-One cognizant engineer indicated } \\
\text { he had made the determination on } \\
\text { whether or not an authorized } \\
\text { worker's lockout/tagout could be } \\
\text { used by itself based on a } \\
\text { conversation with the PIC rather } \\
\text { than by drawing or document } \\
\text { review. }\end{array}$ & & $x$ \\
\hline
\end{tabular}




\begin{tabular}{|c|c|c|c|c|}
\hline \multirow{2}{*}{$\begin{array}{l}\text { SUBJECT/ACTIVITY } \\
\text { REQUIRENENT REFERENCE }\end{array}$} & \multirow{2}{*}{$\begin{array}{l}\text { EVIDENCE EXAMINED/ } \\
\text { PERSONNEL CONTACTED }\end{array}$} & \multirow{2}{*}{ OBSERVATIONS/COMMENTS } & \multicolumn{2}{|c|}{ COMPLY } \\
\hline & & & YES & NO \\
\hline $\begin{array}{l}\text { 5. Are active tagout } \\
\text { authorizations surveyed monthly? } \\
\text { CM-5-34(3.14/5.9) }\end{array}$ & $\begin{array}{l}\text { Beth Wright } \\
\text { L\&T Togbook for CWC }\end{array}$ & $\begin{array}{l}\text { Only one active tagout existed in } \\
\text { the L\&T logbook. It had not been } \\
\text { in place long enough for a } \\
\text { surveillance. } \\
\text { Not Observed }\end{array}$ & & \\
\hline $\begin{array}{l}\text { 8. Are Lock \& Tag surveillance } \\
\text { deficiencies documented \& } \\
\text { tracked to closure? (Waste } \\
\text { Remediation Tracking System) } \\
\text { CM-5-34(3.14/5.10) }\end{array}$ & Not reviewed & $\begin{array}{l}\text { No deficiencies were available for } \\
\text { review }\end{array}$ & & \\
\hline $\begin{array}{l}\text { 9. Are safe condition checks } \\
\text { properly documented? }\end{array}$ & $\begin{array}{l}\text { Reviewed } 20 \text { closed work } \\
\text { packages. }\end{array}$ & $\begin{array}{l}\text { Only } 2 \text { work packages required } L \text { \& } \\
\mathrm{T} \text { and the safe condition checks } \\
\text { were adequately documented. } \\
\text { No work on the daity release sheet } \\
\text { required lock and tag. }\end{array}$ & $x$ & \\
\hline
\end{tabular}

WHC-CM-5-34, Sec. 3.0, 3.15, Independent Verification

\begin{tabular}{|c|c|c|c|c|}
\hline \multirow{2}{*}{$\begin{array}{l}\text { SUBJECT/ACTIVITY } \\
\text { REQUIREMENT REFERENCE }\end{array}$} & \multirow{2}{*}{$\begin{array}{l}\text { EVIDENCE EXAMINED/ } \\
\text { PERSONNEL CONTACTED }\end{array}$} & \multirow[b]{2}{*}{ OBSERVATIONS/COMMENTS } & \multicolumn{2}{|c|}{ COMPLY } \\
\hline & & & YES & No \\
\hline 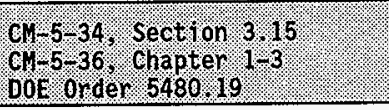 & & & & \\
\hline $\begin{array}{l}\text { 1. Are independent } \\
\text { verifications conducted } \\
\text { separately and properly? }\end{array}$ & $\begin{array}{l}\text { Included in } C M-5-34 \text {, Section } \\
3.15,5.3\end{array}$ & $\begin{array}{l}\text { The administrative requirements } \\
\text { are in place for independent } \\
\text { verification. However, no } \\
\text { independent verifications were } \\
\text { required or observed during this } \\
\text { review. }\end{array}$ & & \\
\hline
\end{tabular}


WHC-CM-5-34, Sec. 3.0, 3.16, AT arm Management

\begin{tabular}{|c|c|c|c|c|}
\hline \multirow{2}{*}{$\begin{array}{c}\text { SUBJECT/ACTIVITY } \\
\text { REQUIREMENT REFERENCE }\end{array}$} & \multirow{2}{*}{$\begin{array}{l}\text { EVIDENCE EXAMINED/ } \\
\text { PERSONNEL CONTACTED }\end{array}$} & \multirow{2}{*}{ OBSERVATIONS/COMMENTS } & \multicolumn{2}{|c|}{ COMPLY } \\
\hline & & & YES & NO \\
\hline 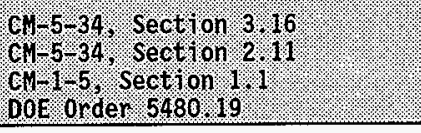 & & & & \\
\hline $\begin{array}{l}\text { 1. Are non-active alarms } \\
\text { labeled? }\end{array}$ & $\begin{array}{l}\text { Included in } \mathrm{CM}-5-34 \text {, Section } \\
3.16,5.0 .1 \\
\text { Observation of Surveillance } \\
\text { rounds }\end{array}$ & $\begin{array}{l}\text { The } 2403 \text { series buildings have } \\
\text { non-active CAM alarms which are } \\
\text { not labelled. }\end{array}$ & & $x$ \\
\hline $\begin{array}{l}\text { 2. Do active alarms have a } \\
\text { plant operating procedure? }\end{array}$ & $\begin{array}{l}\text { Included in } C M-5-34 \text {, Section } \\
3.16,5.0 .2 \\
\text { Reviewed a } 1 \text { arm response } \\
\text { procedures }\end{array}$ & $\begin{array}{l}\text { Active alarm response procedures } \\
\text { are included in SW-001-330 and SW- } \\
150-003 \\
\text { These procedures have been updated } \\
\text { for the } 2404 \text { buildings. }\end{array}$ & $x$ & \\
\hline $\begin{array}{l}\text { 3. Is receipt of alarms } \\
\text { documented in the Facility } \\
\text { Logbooks? }\end{array}$ & $\begin{array}{l}\text { Included in CM-5-34, Section } \\
3.16,5.0 .3 \\
\text { Facility Logbook in MO- } 288\end{array}$ & $\begin{array}{l}\text { Alarms receipt and clearing is } \\
\text { logged in the facility logbook at } \\
\text { MO-288. }\end{array}$ & $X$ & \\
\hline $\begin{array}{l}\text { 4, Do failed al arms have } \\
\text { alternate methods established } \\
\text { for monitoring required } \\
\text { parameters? }\end{array}$ & $\begin{array}{l}\text { Included in CM-5-34, Section } \\
3.16,6.4 \\
\text { Reviewed facility logbook in } \\
\text { M) }-288 \text { and toured facility. }\end{array}$ & $\begin{array}{l}\text { No failed alarms were noted during } \\
\text { this review. } \\
\text { Not observed }\end{array}$ & & \\
\hline
\end{tabular}

WHC-CM-5-34, Sec. 3.0, 3.17, Logkeeping

\begin{tabular}{||c|c|c|c|}
\hline \hline $\begin{array}{c}\text { SUBJECT/ACTIVITY } \\
\text { REQUIREMENT REFERENCE }\end{array}$ & $\begin{array}{c}\text { EVIDENCE EXAMINED/ } \\
\text { PERSONNEL CONTACTED }\end{array}$ & COMPLY \\
\cline { 2 - 4 } & OBSERVATIONS/COMMENTS & YES & NO \\
\hline
\end{tabular}




\begin{tabular}{|c|c|c|c|c|}
\hline 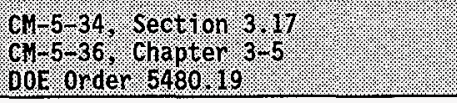 & & & & $\sqrt{6}$ \\
\hline $\begin{array}{l}\text { 1. Is a Narrative Logbook } \\
\text { maintained? }\end{array}$ & $\begin{array}{l}\text { Included in CM-5-34, Section } \\
3.17,5.0 \\
\text { Reviewed logbook in M0-288 and } \\
\text { interviewed Mike Aichele and } \\
\text { Steve Kennelly. }\end{array}$ & $\begin{array}{l}\text { A Facility Logbook is maintained } \\
\text { in } \mathrm{M} 0-288 \text {. }\end{array}$ & $x$ & \\
\hline $\begin{array}{l}\text { 2. Are entries in the Narrative } \\
\text { Logbook clear, concise, complete } \\
\text { and legible? }\end{array}$ & $\begin{array}{l}\text { Included in CM-5-34, Section } \\
3.17,6.1 .4\end{array}$ & $\begin{array}{l}\text { The Facility Logbook in Mo-288 is } \\
\text { clear and legible. }\end{array}$ & $x$ & \\
\hline $\begin{array}{l}\text { 3. Is the author of any logbook } \\
\text { entry clearly identified? }\end{array}$ & $\begin{array}{l}\text { Included in } C M-5-34 \text {, Section } \\
3.17,6.1 .9\end{array}$ & $\begin{array}{l}\text { The Facjlity Logbook in MO- } 288 \\
\text { clearly indicates who is making } \\
\text { entries. }\end{array}$ & $x$ & \\
\hline $\begin{array}{l}\text { 4. Are logbooks reviewed daily } \\
\text { by operations Manager/Team } \\
\text { Leader? }\end{array}$ & $\begin{array}{l}\text { Included in CM-5-34, Section } \\
3.17,6.1\end{array}$ & $\begin{array}{l}\text { The Team Leader reviewed the } \\
\text { logbook and used some entries for } \\
\text { briefing personnel on } 5 / 12 \text {. }\end{array}$ & $x$ & \\
\hline
\end{tabular}

WHC-CM-5-34, Sec. 3.0, 3.18, Operations Turnover

\begin{tabular}{|c|c|c|c|c|}
\hline \multirow{2}{*}{$\begin{array}{c}\text { SUBJECT/ACTIVITY } \\
\text { REQUIREMENT REFERENCE }\end{array}$} & \multirow{2}{*}{$\begin{array}{l}\text { EVIDENCE EXAMINED/ } \\
\text { PERSONNEL CONTACTED }\end{array}$} & \multirow{2}{*}{ OBSERVATIONS/COMMENTS } & \multicolumn{2}{|c|}{ COMPLY } \\
\hline & & & YES & NO \\
\hline GM. 5.34, Sect tion, $3 \cdot 18$ & & & & . \\
\hline $\begin{array}{l}\text { 1. Is a briefing given by the } \\
\text { Operations Team Leader/Designee } \\
\text { prior to beginning shift } \\
\text { activities? }\end{array}$ & $\begin{array}{l}\text { Included in } C M-5.34 \text {, Section } \\
3.18,5.1 .3 \\
\text { Observed turnover on } 5 / 12\end{array}$ & $\begin{array}{l}\text { The Team Leader provided a clear } \\
\text { briefing of operations and } \\
\text { potential problems. }\end{array}$ & $X$ & \\
\hline
\end{tabular}


WHC-CM-5-34, Sec. 3.0, 3.20, Required Reading

\begin{tabular}{|c|c|c|c|c|}
\hline \multirow{2}{*}{$\begin{array}{l}\text { SUBJECT/ACTIVITY } \\
\text { REQUIREMENT REFERENCE }\end{array}$} & \multirow{2}{*}{$\begin{array}{l}\text { EVIDENCE EXAMINED/ } \\
\text { PERSONNEL CONTACTED }\end{array}$} & \multirow{2}{*}{ OBSERVATIONS/COMMENTS } & \multicolumn{2}{|c|}{ COMPLY } \\
\hline & & & YES & NO \\
\hline 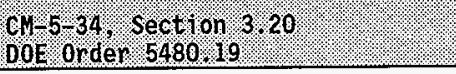 & & & & \\
\hline $\begin{array}{l}\text { 1. Is Required Reading material } \\
\text { kept readily available? }\end{array}$ & $\begin{array}{l}\text { Included in } C M-5-34 \text {, Section } \\
3.20,4.3 \\
\text { Reviewed required reading in } \\
\text { MO- } 288 \text {. }\end{array}$ & $\begin{array}{l}\text { Required reading is controlled by } \\
\text { routing sheets. Reviews are } \\
\text { performed and signed off by } \\
\text { appropriate personnel. Non-timely } \\
\text { reviews are followed up by the } \\
\text { Operations Secretary and the Team } \\
\text { Leader. }\end{array}$ & $x$ & \\
\hline $\begin{array}{l}\text { 3. Is required Reading } \\
\text { completed in a timely manner? }\end{array}$ & $\begin{array}{l}\text { Included in } \mathrm{CM}-5-34 \text {, Section } \\
3.20,4.4\end{array}$ & $\begin{array}{l}\text { Required reading available in MO- } \\
288 \text { was being performed in a } \\
\text { timely manner. }\end{array}$ & $x$ & \\
\hline
\end{tabular}

WHC-CM-5-34, Sec. 3.0, 3.22, Operation Procedures

\begin{tabular}{|c|c|c|c|c|}
\hline \multirow{2}{*}{$\begin{array}{c}\text { SUBJECT/ACTIVITY } \\
\text { REQUIREMENT REFERENCE }\end{array}$} & \multirow{2}{*}{$\begin{array}{l}\text { EVIDENCE EXAMINED/ } \\
\text { PERSONNEL CONTACTED }\end{array}$} & \multirow{2}{*}{ OBSERVATIONS/COMMENTS } & \multicolumn{2}{|c|}{ COMPLY } \\
\hline & & & YES & No \\
\hline 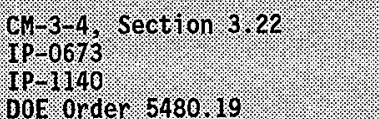 & & & & Y \\
\hline
\end{tabular}




\begin{tabular}{|c|c|c|c|c|}
\hline \multirow{2}{*}{$\begin{array}{c}\text { SUBJECT/ACTIVITY } \\
\text { REQUIREMENT REFERENCE }\end{array}$} & \multirow{2}{*}{$\begin{array}{l}\text { EVIDENCE EXAMINED/ } \\
\text { PERSONNEL CONTACTED }\end{array}$} & \multirow{2}{*}{ OBSERVATIONS/COMMENTS } & \multicolumn{2}{|c|}{ COMPLY } \\
\hline & & & YES & NO \\
\hline $\begin{array}{l}\text { 1. Are procedures that are not } \\
\text { step sensitive designated by } \\
\text { Standing Order? }\end{array}$ & $\begin{array}{l}\text { Included in } C M-5-34 \text {, Section } \\
3.22,3.4 .1 .1) \\
\text { Mike Aichele } \\
\text { Long Term Standing Order book }\end{array}$ & $\begin{array}{l}\text { There is a long term standing } \\
\text { order available in M0-720 which } \\
\text { specifically lists those } \\
\text { procedures which are not step } \\
\text { sensitive. } \\
\text { There is also a note in some } \\
\text { procedures which indicate they are } \\
\text { not step sensitive. }\end{array}$ & $X$ & \\
\hline $\begin{array}{l}\text { 2. Are procedures that are not } \\
\text { to be in hand during use } \\
\text { designated by Standing Order? }\end{array}$ & $\begin{array}{l}\text { Included in CM-5-34, Section } \\
3.22,3.4 .1 .4) \\
\text { Mike Aiche } \\
\text { Long Term Standing Order book }\end{array}$ & $\begin{array}{l}\text { There is a long term standing } \\
\text { order available in M0- } 720 \text { which } \\
\text { lists those procedures which do } \\
\text { not have to be in hand. }\end{array}$ & $X$ & \\
\hline
\end{tabular}

WHC-CM-5-34, Sec. 3.0, 3.23, Operator Aid Posting

\begin{tabular}{|c|c|c|c|c|}
\hline \multirow{2}{*}{$\begin{array}{c}\text { SUBJECT/ACTIVITY } \\
\text { REQUIREMENT REFERENCE }\end{array}$} & \multirow{2}{*}{$\begin{array}{l}\text { EVIDENCE EXAMINED/ } \\
\text { PERSONNEL CONTACTED }\end{array}$} & \multirow{2}{*}{ OBSERVATIONS/COMMENTS } & \multicolumn{2}{|c|}{ COMPLY } \\
\hline & & & YES & No \\
\hline 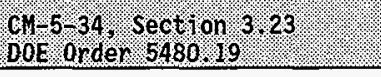 & & & & \\
\hline $\begin{array}{l}\text { 1. Are Operator Aids } \\
\text { authorized? }\end{array}$ & $\begin{array}{l}\text { Included in CM-5-34, Section } \\
3.22,4.2) \\
\text { observation of Surveillance } \\
\text { rounds }\end{array}$ & $\begin{array}{l}\text { CPS sheets are posted in each } \\
\text { building as required. They are } \\
\text { audited, but not controlled as } \\
\text { operator aids. }\end{array}$ & $x$ & \\
\hline $\begin{array}{l}\text { 2. Are Operator Aids } \\
\text { periodically reviewed and } \\
\text { surveyed? }\end{array}$ & $\begin{array}{l}\text { Included in }(M-5-34 \text {, Section } \\
4.2,4.4,4.5 \\
\text { Operator Aid Log in M) }-288 \text {. }\end{array}$ & $\begin{array}{l}\text { Only one operator aid was included } \\
\text { in the logbook and it is being } \\
\text { surveyed. } \\
\text { Field review of the } 2404 \text { MET areas } \\
\text { found the operator aids in place. }\end{array}$ & $x$ & \\
\hline
\end{tabular}


WHC-CM-5-34, Sec. 3.0 3.24, Equipment and Piping Labeling

\begin{tabular}{|c|c|c|c|c|}
\hline \multirow{2}{*}{$\begin{array}{l}\text { SUBJECT/ACTIVITY } \\
\text { REQUIREMENT REFERENCE }\end{array}$} & \multirow{2}{*}{$\begin{array}{l}\text { EVIDENCE EXAMINED/ } \\
\text { PERSONNEL CONTACTED }\end{array}$} & \multirow{2}{*}{ OBSERVATIONS/COMMENTS } & \multicolumn{2}{|c|}{ COMPLY } \\
\hline & & & YES & NO \\
\hline $\begin{array}{l}\text { CHOE } 5-34 . \\
\text { DOE Order Section } 5480.19\end{array}$ & & & & 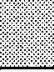 \\
\hline $\begin{array}{l}\text { 1. Are temporary } 1 \text { abels } \\
\text { validated correctly installed by } \\
\text { the Operations Team Leader? }\end{array}$ & $\begin{array}{l}\text { Included in } \mathrm{CM}-5-34 \text {, Section } \\
3.24,3.4 \text {. } \\
2404 \text { building tour } \\
\text { M. Aichele } \\
\text { B. Rogers }\end{array}$ & $\begin{array}{l}\text { No temporary labels were posted in } \\
\text { the } 2404 \text { buildings. }\end{array}$ & $x$ & \\
\hline $\begin{array}{l}\text { 2. Are labels installed on } \\
\text { valves, dampers, instruments, } \\
\text { gages, pipes, ducts, major } \\
\text { equipment, busses, Mccs, power } \\
\text { panels, breakers, switches, room } \\
\text { doors, emergency equipment, and } \\
\text { fire protection systems? }\end{array}$ & $\begin{array}{l}\text { Included in } \mathrm{CM}-5-34 \text {, Section } \\
3.24,4.1 \\
2404 \text { building tour } \\
\text { M. Aichele } \\
\text { B. Rogers }\end{array}$ & $\begin{array}{l}\text { No labeling deficiencies were } \\
\text { noted during facility inspections. }\end{array}$ & $x$ & \\
\hline $\begin{array}{l}\text { 3. Are areas requiring PPE such } \\
\text { as hard hats clearly understood } \\
\text { and/or marked? }\end{array}$ & $\begin{array}{l}\text { Tour of facility } \\
\text { Procedure } 043 \text { and } 110 \text { review }\end{array}$ & $\begin{array}{l}\text { There were no areas requiring PPE } \\
\text { observed during this review. } \\
\text { Facility procedures do require use } \\
\text { of PPE for some operations. }\end{array}$ & $x$ & \\
\hline
\end{tabular}


WHC-CM-5-34, Sec. 3.0, 3.21, Timely Orders to Operators

\begin{tabular}{|c|c|c|c|c|}
\hline \multirow{2}{*}{$\begin{array}{c}\text { SUBJECT/ACTIVITY } \\
\text { REQUIREMENT REFERENCE }\end{array}$} & \multirow{2}{*}{$\begin{array}{l}\text { EVIDENCE EXAMINED/ } \\
\text { PERSONNEL CONTACTED }\end{array}$} & \multirow{2}{*}{ OBSERVATIONS/COMMENTS } & \multicolumn{2}{|c|}{ COMPLY } \\
\hline & & & YES & NO \\
\hline $\begin{array}{l}\text { CH. 5-34. sect ion } 3.21 \\
\text { DOE onder } 5480.19\end{array}$ & & & & \\
\hline $\begin{array}{l}\text { 1. Are daily orders } \\
\text { communicated through shift } \\
\text { briefs before personnel assume } \\
\text { shift responsibility? }\end{array}$ & $\begin{array}{l}\text { Included in } \mathrm{CM}-5-34 \text {, Section } \\
3.21,5.2 \\
\text { Attended shift briefing on } 5 / 12\end{array}$ & $\begin{array}{l}\text { No specific daily orders are } \\
\text { issued at CWC. However, the Team } \\
\text { Leader did a good job of covering } \\
\text { the Daily Release Sheet and } \\
\text { potential problems. }\end{array}$ & $x$ & \\
\hline
\end{tabular}


CORE REQUIREMENT: 13) There are sufficient numbers of qualified personnel to support safe operations. Note: This Core Requirement is only to ensure adequate numbers of qualified personnel. Assessment of qualification is addressed under Core Requirements $2 \& 3$.

\section{APPROACH:}

1. Using qualification records and job assignment records, compare the numbers of qualified personnel to the staffing levels identified by facility management to ensure Criterion 13.1 is met.

2. Verify the staffing levels are greater than or equal to any minimum staffing requirements identified in the authorization basis.

3. Review and assess staffing requirements identified by the authorization basis and line management by witnessing the performance or walking down plant operating procedure and work plans to verify that adequate numbers of personnel are available to operate the systems.

CRITERIA: 1. There is an adequate number of qualified personnel for the mission of the facility. 2. The staffing requirements are adequate to ensure safe operations. 


\begin{tabular}{|c|c|c|c|c|}
\hline \multirow{2}{*}{$\begin{array}{c}\text { SUBJECT/ACTIVITY } \\
\text { REQUIREMENT REFERENCE }\end{array}$} & \multirow{2}{*}{$\begin{array}{l}\text { EVIDENCE EXAMINED/ } \\
\text { PERSONNEL CONTACTED }\end{array}$} & \multirow[t]{2}{*}{ OBSERVATIONS/COMMENTS } & \multicolumn{2}{|c|}{ COMPLY } \\
\hline & & & YES & NO \\
\hline $\begin{array}{l}\text { 1) Core Rqmt. } 13 \\
\text { Criteria 1.\& } 2 .\end{array}$ & $\begin{array}{l}\text { ISB, Organization } \\
\text { Charts, } \\
\text { FM - Robert Giroir } \\
\text { OPN - Paul Crane } \\
\text { OPN - Michael Aichele } \\
\text { OPN - Jim Mitchell } \\
\text { ENG - Mat Irwin } \\
\text { RC - Brad Brannan } \\
\text { ENV - Kent McDonald }\end{array}$ & $\begin{array}{l}\text { Staffing specified in the ISB requires } \\
\text { only one supervisor, one qualified } \\
\text { operator, and one rad con tech. to operate } \\
\text { the facility. A review of the } \\
\text { organization chart and discussion with CWC } \\
\text { management showed that the staffing } \\
\text { required on any given day of operations } \\
\text { needs one to six teams. There are } 23 \\
\text { operators between the CWC \& Burial } \\
\text { Grounds. Cross training has been } \\
\text { conducted. There are } 10 \text { Rad Con Techs that } \\
\text { provide coverage from waste receipt } \\
\text { exposure determination/verification to } \\
\text { routine surveillance of the work } \\
\text { environment. Full time Rad Con coverage of } \\
\text { a given waste handling operation depends } \\
\text { on exposure levels. Management considers } \\
\text { there may be more staff than is needed for } \\
\text { the current volume of waste handling } \\
\text { operations \& is evaluating the } \\
\text { current/planned actual staffing need in } \\
\text { conjunction with the ongoing S/RID } \\
\text { revision. }\end{array}$ & $x$ & \\
\hline
\end{tabular}




\section{PHASE V STORAGE ORR APPRAISAL FORM}

CORE REQUIREMENT: CR 15 The facility systems and procedures as effected by facility modifications are consistent with the description of the facility, procedures, and accident analysis included in the safety basis.

APPROACH: Review procedure validation, walkdown, and review comment steps for recent procedure changes that incorporate the CWC 2404 phase $V$ facility and have correctly included the requirements of the safety basis(this inciudes operating, maintenance, and administrative procedures).

\section{CRITERIA:}

1. Operations, maintenance, surveillance, and administrative procedures have been adequately updated to reflect the facility modifications and meet or exceed the operational performance guidance provided in DOE order 5480.19.

2. Operations, maintenance, surveillance, and administrative procedures implement the changes made in the approved safety basis resulting from the facility modifications.

\begin{tabular}{|c|c|c|c|c|}
\hline \multirow{2}{*}{$\begin{array}{c}\text { SUBJECT/ACTIVITY } \\
\text { REQUIREMENT REFERENCE }\end{array}$} & \multirow{2}{*}{$\begin{array}{l}\text { EVIDENCE EXAMINED/ } \\
\text { PERSONNEL CONTACTED }\end{array}$} & \multirow[t]{2}{*}{ OBSERVATIONS/COMMENTS } & \multicolumn{2}{|c|}{ COMPLY } \\
\hline & & & YES & No \\
\hline $\begin{array}{l}\text { 1) Review the changes } \\
\text { made to the plant } \\
\text { operating procedures } \\
\text { for the attributes } \\
\text { listed in the above } \\
\text { criteria. }\end{array}$ & $\begin{array}{l}\text { Reviewed operating } \\
\text { procedures } \\
\text { SW-100-110 Receive } \\
\text { radioactive waste at } \\
\text { the Central Waste } \\
\text { Complex } \\
\text { SW-040-043 Inspect the } \\
\text { CWC and Sodium Storage } \\
\text { Building and Associated } \\
\text { Equipment. } \\
\text { SW-001-330 Respond to } \\
\text { Solid Waste Management } \\
\text { Facility Alarms and } \\
\text { Indicators }\end{array}$ & $\begin{array}{l}\text { The operating procedures correctly } \\
\text { incorporated the } 2404 \text { buildings and the } \\
\text { requirements of the ISB. The procedures } \\
\text { are well structured, concise, and } \\
\text { highi ight ISB and worker safety } \\
\text { requirements appropriately. }\end{array}$ & $x$ & \\
\hline
\end{tabular}




\begin{tabular}{|c|c|c|c|}
\hline $\begin{array}{l}\text { 1a) Review the } \\
\text { validation records to } \\
\text { assure a process } \\
\text { exists and correctly } \\
\text { incorporated the } \\
\text { requirements in the } \\
\text { safety basis. }\end{array}$ & $\begin{array}{l}\text { Operating Procedure } \\
\text { File in M0-720 }\end{array}$ & $\begin{array}{l}\text { Records for procedure development, } \\
\text { revisions, validation and walkdowns were } \\
\text { prepared and retained properly. }\end{array}$ & $x$ \\
\hline $\begin{array}{l}\text { 1b)Review the } \\
\text { operating procedure } \\
\text { walkdown records to } \\
\text { assure demonstrated } \\
\text { independence and } \\
\text { confirm comments were } \\
\text { incorporated into the } \\
\text { released POP. }\end{array}$ & see $1 \mathrm{a}$ & $\begin{array}{l}\text { The operating procedure control process } \\
\text { used at CWC is a computer based system } \\
\text { with controlled change access. The system } \\
\text { works very well. }\end{array}$ & $x$ \\
\hline $\begin{array}{l}\text { 1c) Review the Interim } \\
\text { Safety Basis } \\
\text { implementation matrix } \\
\text { for proper inclusion } \\
\text { of identifying } \\
\text { effected POPs. }\end{array}$ & $\begin{array}{l}\text { HNF-SD-WM-RPT-296, rev } \\
0\end{array}$ & $\begin{array}{l}\text { The effected procedures were identified in } \\
\text { the matrix }\end{array}$ & $x$ \\
\hline
\end{tabular}




\begin{tabular}{|c|c|c|c|}
\hline $\begin{array}{l}\text { 2) Review maintenance } \\
\text { procedures for an } \\
\text { implementing/validatio } \\
\text { n process for the } \\
\text { attributes listed in } \\
\text { the above criteria. }\end{array}$ & $\begin{array}{l}\text { A11 preventative } \\
\text { maintenance procedures. } \\
\text { Paul Hemsworth }\end{array}$ & $\begin{array}{l}\text { The PMs correctly incorporated the } 2404 \\
\text { buildings maintenance needs, but do not } \\
\text { specifically identify ISB requirements or } \\
\text { actions. This is all done using Plant } \\
\text { operating Procedures. }\end{array}$ & $x$ \\
\hline $\begin{array}{l}\text { 2a) Review maintenance } \\
\text { validation for } \\
\text { completeness and } \\
\text { correct implementation } \\
\text { of ISB requirements. }\end{array}$ & See 2 above & see above & $x$ \\
\hline $\begin{array}{l}\text { 2b) Review the } \\
\text { maintenance procedure } \\
\text { walkdown and comment } \\
\text { incorporation records. }\end{array}$ & $\begin{array}{l}\text { Reviewed PMs and the } \\
\text { Job Control System } \\
\text { Procedure in WHC-CM-5- } \\
34 \text { section } 2.17\end{array}$ & $\begin{array}{l}\text { The walkdown records were attached to the } \\
\text { appropriate PM and retained per JCS } \\
\text { procedure. }\end{array}$ & $x$ \\
\hline $\begin{array}{l}\text { 2c) Review the ISB } \\
\text { implementation matrix } \\
\text { for correct inclusion } \\
\text { of maintenance } \\
\text { procedures. }\end{array}$ & Matrix & $\begin{array}{l}\text { Vehicle and Facility maintenance } \\
\text { procedures were correctly identified. }\end{array}$ & $x$ \\
\hline
\end{tabular}




\begin{tabular}{||l|l|l|l||}
\hline $\begin{array}{l}\text { 3)Review the } \\
\text { administrative } \\
\text { procedure change } \\
\text { process for } \\
\text { appropriate inclusion } \\
\text { of the phase V } \\
\text { facilities management } \\
\text { responsibilities. }\end{array}$ & WHC-CM-5-34 & $\begin{array}{l}\text { The administrative procedures are written } \\
\text { so general that they cover the 2404 } \\
\text { facilities. }\end{array}$ & $x$ \\
$\begin{array}{l}\text { 4)Review the governing } \\
\text { administrative } \\
\text { procedures for cWC } \\
\text { operation and assure } \\
\text { that I0SRs are } \\
\text { identified and a } \\
\text { management process is } \\
\text { identified to assure } \\
\text { compliance. }\end{array}$ & WHC-CM-5-34 & $\begin{array}{l}\text { The administrative procedures do not } \\
\text { identify the three IOSRs for CWC uniquely, } \\
\text { but does discuss responsibilities for } \\
\text { some organizations. The management self } \\
\text { assessment did inciude reviewing } \\
\text { compliance with the ISB. }\end{array}$ & $\times$ \\
\hline
\end{tabular}


CORE REQUIREMENT:CR 15 The facility systems and procedures effected by facility modifications, are consistent with the description of the facility, procedures and accident analysis included in the safety basis.

APPROACH: \#2 Interview operations staff to assess their understanding of the operational requirements for the CWC 2404 facility and how the Interim Operational Safety Requirements are met.

\section{CRITERIA:}

\#2 Operations, maintenance, surveillance, and administrative procedures implement the changes made in the approved safety basis resulting from the facility modifications.

\#5 An equipment/system startup program is in place and adequately addresses operational testing to confirm operability of equipment, the viability of procedures, and the training of operators.

\begin{tabular}{|c|c|c|c|c|}
\hline \multirow{2}{*}{$\begin{array}{c}\text { SUBJECT/ACTIVITY } \\
\text { REQUIREMENT REFERENCE }\end{array}$} & \multirow{2}{*}{$\begin{array}{l}\text { EVIDENCE EXAMINED/ } \\
\text { PERSONNEL CONTACTED }\end{array}$} & \multirow[t]{2}{*}{ OBSERVATIONS/COMMENTS } & \multicolumn{2}{|c|}{ CONPLY } \\
\hline & & & YES & NO \\
\hline $\begin{array}{l}\text { 1) Interview operators } \\
\text { and Radiological } \\
\text { Control Technicians to } \\
\text { assess their } \\
\text { understanding of the } \\
\text { ISORs, the additional } \\
\text { responsibilities of } \\
\text { the ISB and how they } \\
\text { participate in meeting } \\
\text { the requirements of } \\
\text { the ISB. }\end{array}$ & $\begin{array}{l}\text { Bruce Rodgers, Don } \\
\text { Brotherton-NPOs }\end{array}$ & $\begin{array}{l}\text { Both demonstrated an excellent } \\
\text { understanding of the IOSRs that they were } \\
\text { responsible for, i.e., } 6.2 .2 .2 \text {-Source } \\
\text { Control } 6.2 .2 .3 \text { criticality. They did not } \\
\text { have a clear understanding of IOSR } 6.2 .2 .1 \\
\text { for organization. }\end{array}$ & $x$ & \\
\hline
\end{tabular}




\begin{tabular}{|c|c|c|c|}
\hline $\begin{array}{l}\text { 2) Interview } \\
\text { maintenance and work } \\
\text { control staff to } \\
\text { assess their } \\
\text { understanding of the } \\
\text { ISORs and their } \\
\text { implementation. }\end{array}$ & $\begin{array}{l}\text { Paul Hemsworth, Pat } \\
\text { Bott }\end{array}$ & $\begin{array}{l}\text { Both had a general understanding of the } \\
\text { ISB and associated IOSRs, but did not have } \\
\text { a working knowledge of specific } \\
\text { implementation. Maintenance relies on } \\
\text { Engineering for Authorization Basis } \\
\text { management and Operations for } \\
\text { implementation. }\end{array}$ & $x$ \\
\hline $\begin{array}{l}\text { 3) Interview } \\
\text { maintenance and work } \\
\text { control staff as to } \\
\text { their participation in } \\
\text { the startup of the CWC } \\
2404 \text { facilities, the } \\
\text { testing that was } \\
\text { conducted and if } \\
\text { training was adequate } \\
\text { to perform the } \\
\text { necessary maintenance. } \\
\text { Also assess their } \\
\text { understanding of the } \\
\text { operation and } \\
\text { maintenance } \\
\text { requirements of safety } \\
\text { support systems. }\end{array}$ & $\begin{array}{l}\text { Pat Bott, Paul } \\
\text { Hemsworth }\end{array}$ & $\begin{array}{l}\text { Participation by maintenance was primarily } \\
\text { in revising the PMs for CWC to include the } \\
2404 \text { facilities. Frustration was noted in } \\
\text { that with the type of contracting process } \\
\text { used for W112 the contractor supplied a } \\
\text { turn key facility with an Acceptance Test } \\
\text { Report. No OTPs were conducted with the } \\
\text { operating organization. }\end{array}$ & $X$ \\
\hline
\end{tabular}




\begin{tabular}{|c|c|c|c|}
\hline $\begin{array}{l}\text { 4) same as ( } 3 \text { ) above } \\
\text { but interview } \\
\text { operations staff. }\end{array}$ & $\begin{array}{l}\text { Bruce Rodgers-NPO } \\
\text { Mike Aichele-Team Lead } \\
\text { Paul Crane-0ps Manager }\end{array}$ & $\begin{array}{l}\text { Operations participation was actually a } \\
\text { teaming effort with Maintenance and } \\
\text { Engineering to achieve a startup status } \\
\text { for the facility and associated systems. } \\
\text { Strong desire exhibited by all to know } \\
\text { their systems well and operate them } \\
\text { correctly. }\end{array}$ & $X$ \\
\hline $\begin{array}{l}\text { 5) Interview technical } \\
\text { support staff as to } \\
\text { their understanding of } \\
\text { their responsibilities } \\
\text { as it pertains to } \\
\text { compliance with The } \\
\text { ISORs, the closeout of } \\
\text { actions from the ISB } \\
\text { implementation matrix, } \\
\text { and the processes used } \\
\text { to both comply and } \\
\text { update the Safety } \\
\text { Basis. }\end{array}$ & $\begin{array}{l}\text { Matt Irwin Engr Mgr } \\
\text { Randy Ames-Engr Lead } \\
\text { WiTl Hansen-Fac Project } \\
\text { Engr. }\end{array}$ & $\begin{array}{l}\text { Very knowledgeable technical staff that } \\
\text { works well with the used organizations (Ops } \\
\text { and Maintenance). . Strong ownership of the } \\
\text { Authorization Basis including USQs, } \\
\text { updates, supporting training. The } \\
\text { training provided by Randy Ames on the ISB } \\
\text { for CWC was very high quality and focused } \\
\text { on the users. }\end{array}$ & $x$ \\
\hline
\end{tabular}




\begin{tabular}{|c|c|c|c|}
\hline $\begin{array}{l}\text { 6) Interview CWC } \\
\text { management and } \\
\text { leadership personneT } \\
\text { to assess their } \\
\text { understanding of their } \\
\text { responsibilities for } \\
\text { compliance to the ISB } \\
\text { and how the CWC } 2404 \\
\text { facilities have } \\
\text { increased their } \\
\text { responsibilities. }\end{array}$ & $\begin{array}{l}\text { Paut Crane, Susan } \\
\text { Stitt, Matt Irwin, Mike } \\
\text { Aicheile, Paul } \\
\text { Hemsworth }\end{array}$ & $\begin{array}{l}\text { Good understanding of the ISB and } \\
\text { associated IOSRS. The IOSR on } \\
\text { Organization, \#6.2.2.I was not understood } \\
\text { as to how it is being complied with, } \\
\text { although the Engineering Manager did } \\
\text { understand the annual letter to RL that } \\
\text { showed evidence of the organization. How } \\
\text { SWITS is utilized was discussed, and } \\
\text { discovered that it is not being managed as } \\
\text { a technical basis document, but as a } \\
\text { programmatic support data base. }\end{array}$ & $x$ \\
\hline $\begin{array}{l}\text { 7) Interview technical } \\
\text { support and management } \\
\text { personne } 1 \text { to determine } \\
\text { if a facility } \\
\text { modification startup } \\
\text { program is in place } \\
\text { and was administered } \\
\text { adequately for the CWC } \\
\text { 2404 facility. }\end{array}$ & same as above & $\begin{array}{l}\text { A unique startup program is not utilized. } \\
\text { Corrective Maintenance or small projects } \\
\text { are used for this type of activity. }\end{array}$ & $x$ \\
\hline
\end{tabular}


PHASE V STORAGE ORR APPRAISAL FORM

CORE REQUIREMENT:CR 15 The facility systems and procedures as effected by facility modifications, are consistent with the description of the facility, procedures, and accident analysis included in the safety basis.

APPROACH: \#3 Interview technical support staff to assess their knowledge of both the operational and administrative procedure change process that implemented the additional requirements of the CWC 2404 facility.

\section{CRITERIA:}

1. Operations, maintenance, surveiliance, and administrative procedures implement the changes made in the approved safety basis resulting from the facility modifications.

7. Utility and support systems are operable, fully functional, and meet the performance requirements of the approved safety basis.

\begin{tabular}{||l|l|l|l||}
\hline $\begin{array}{c}\text { SUBJECT/ACTIVITY } \\
\text { REQUIREMENT REFERENCE }\end{array}$ & \multicolumn{1}{|c|}{$\begin{array}{l}\text { EVIDENCE EXAMINED/ } \\
\text { PERSONNEL CONTACTED }\end{array}$} & OBSERVATIONS/COMMENTS & COMPLY \\
\hline \hline $\begin{array}{l}\text { 1)Interview technical } \\
\text { support staff to } \\
\text { assess their knowledge } \\
\text { of the operational } \\
\text { procedure change } \\
\text { process, show evidence } \\
\text { it was used for the } \\
\text { startup up of the CWC } \\
\text { 2404 facility, and the } \\
\text { requirements of the } \\
\text { ISB are noted } \\
\text { appropriately. }\end{array}$ & & $\begin{array}{l}\text { Reviewed the updated }-110 \text { and }-043 \\
\text { procedure change/update process. } \\
\text { Excellent working knowledge and strong } \\
\text { relationship with operations to achieve a } \\
\text { quality product. }\end{array}$ & X* \\
& & & \\
\end{tabular}




\begin{tabular}{|c|c|c|c|}
\hline $\begin{array}{l}\text { 2) Interview technical } \\
\text { support staff to } \\
\text { assess their knowledge } \\
\text { of the administrative } \\
\text { procedure change } \\
\text { process, show evidence } \\
\text { it was utilized for } \\
\text { the startup of the CWC } \\
2404 \text { facility and the } \\
\text { requirements of the } \\
\text { ISB are noted } \\
\text { appropriately. }\end{array}$ & same as above & $\begin{array}{l}\text { Engineering was the initiating } \\
\text { organization for the administrative } \\
\text { procedure changes as they related to } 2404 \\
\text { startup and ISB implementation. }\end{array}$ & $x$ \\
\hline $\begin{array}{l}\text { 3) Interview management } \\
\text { and leadership staff } \\
\text { to assess their } \\
\text { knowledge of the } \\
\text { operational and } \\
\text { administrative } \\
\text { procedure change } \\
\text { process and } \\
\text { demonstrate } \\
\text { performance of a self } \\
\text { assessment program } \\
\text { that addresses both. }\end{array}$ & $\begin{array}{l}\text { S Stitt, M Irwin, } P \\
\text { Crane. }\end{array}$ & $\begin{array}{l}\text { Good knowledge of change processes. } \\
\text { Adjustments to the self assessment program } \\
\text { that is more focused on how to improve } \\
\text { performance, not improved compliance would } \\
\text { provide benefit. }\end{array}$ & $x$ \\
\hline
\end{tabular}




\begin{tabular}{|c|c|c|c|}
\hline $\begin{array}{l}\text { 4) Interview exempt } \\
\text { staff responsible for } \\
\text { the MYPP to } \\
\text { demonstrate the } \\
\text { operation of the CWC } \\
2404 \text { facility was } \\
\text { included in the } \\
\text { baseline funding. }\end{array}$ & John Lang & $\begin{array}{l}2404 \text { facilities were in included in the } \\
\text { MYPP project baseline }\end{array}$ & $x$ \\
\hline $\begin{array}{l}\text { 5) Interview technical } \\
\text { support personne } 1 \text { to } \\
\text { demonstrate how the } \\
\text { successful startup of } \\
\text { the CWC } 2404 \text { facility } \\
\text { was conducted, } \\
\text { including using the } \\
\text { appropriate data from } \\
\text { the ATPs and OTPs that } \\
\text { were conducted. }\end{array}$ & $\begin{array}{l}\text { Randy Ames, Will Hansen } \\
\text {. }\end{array}$ & $\begin{array}{l}\text { As previously noted the W112 project was a } \\
\text { fixed price turn key contract. The ATP } \\
\text { was conducted by the vendor and documented } \\
\text { in an ATR. Engineering has prepared a } \\
\text { good technical package for operation of } \\
\text { the } 2404 \text { facility. }\end{array}$ & $X$ \\
\hline
\end{tabular}




\section{PHASE V STORAGE ORR APPRAISAL FORM}

CORE REQUIREMENT:CR 15 The facility systems and procedures as effected by facility modifications, are consistent with the description of the facility, procedures, and accident analysis in the safety basis.

\section{APPROACH:}

\#4 Review with technical support personnel that vendor drawings, specifications, and operational characteristic data have been properly incorporated and user staff notified.

\#5 Review with technical support personnel responsibie for modifications that vendor turnover open $i t e^{2}$ have been properly dispositioned and a formal process to verify construction activities met functional design was utilized.

\section{CRITERIA:}

\#4 Drawings and other documentation relied upon for operations and maintenance activities are consistent with the new existing plant configuration.

\#6 Construction vendors have completed al1 work and appropriate turnover documentation has been supplied to the operating organization. This needs to include the construction checklist and open items punchlists. \#8 A USQ screening relative to the planned modification was completed prior to initiation of design and was appropriately dispositioned.

\#9 The Functionat Design Criteria for modifications was utilized by the construction vendors for design, fabrication, and installation(includes conducting ATP and OTPs). 


\begin{tabular}{|c|c|c|c|c|}
\hline \multirow{2}{*}{$\begin{array}{c}\text { SUBJECT/ACTIVITY } \\
\text { REQUIREMENT REFERENCE }\end{array}$} & \multirow{2}{*}{$\begin{array}{l}\text { EVIDENCE EXAMINED/ } \\
\text { PERSONNEL. CONTACTED }\end{array}$} & \multirow[t]{2}{*}{ OBSERVATIONS/COMMENTS } & \multicolumn{2}{|c|}{ COMPLY } \\
\hline & & & YES & No \\
\hline $\begin{array}{l}\text { 1) Interview technical } \\
\text { support staff to } \\
\text { review the USQ } \\
\text { screening performed } \\
\text { was appropriate for } \\
\text { the addition of the } \\
\text { CWC } 2404 \text { facility. }\end{array}$ & $\begin{array}{l}\text { Randy Ames: } \\
\text { USQ Screening \# SWMFE- } \\
\text { USQ-97-014 } \\
\text { EDT\#600024 SAFETY } \\
\text { ASSESSMENT FOR W112 } \\
\text { PROJECT } \\
\text { USQ log and file }\end{array}$ & $\begin{array}{l}\text { 1. The USQ screening conducted on April } \\
15,1997 \text { is for the operating procedure } \\
\text { change to include the } 2404 \text { buildings. The } \\
\text { log was complete and under control with } \\
\text { the controlled file. This should close } \\
\text { out and FEB action item. } \\
2 \text {. The W-112 project safety assessment } \\
\text { that was prepared in August } 1995 \text { did } \\
\text { appropriately address the additional } \\
\text { hazards of the } 2404 \text { facility. The Safety } \\
\text { ASSessment preparation was preceded by an } \\
\text { USQ Screen that resulted in a Yes/Maybe } \\
\text { determination that the Safety Assessment } \\
\text { resolved. }\end{array}$ & $x$ & \\
\hline $\begin{array}{l}\text { 2) Interview and review } \\
\text { with technical support } \\
\text { staff the approved } \\
\text { functional design } \\
\text { criteria used for the } \\
\text { CWC } 2404 \text { facilities } \\
\text { and was utilized } \\
\text { during design and } \\
\text { construction. }\end{array}$ & $\begin{array}{l}\text { Randy Ames: } \\
\text { FDC-SD-W112-FDC- } \\
\text { 001,revl:Functional } \\
\text { Design Criteria used } \\
\text { for the project. The } \\
\text { project was eventually } \\
\text { descope and included } \\
\text { only the } 2404 \text { phase } V \\
\text { addition to CWC and the } \\
\text { WRAP support buildings } \\
\text { which are not part of } \\
\text { this review. }\end{array}$ & $\begin{array}{l}\text { The FDC was complete and utilized during } \\
\text { design and construction. The construction } \\
\text { documentation supplied confirmed the FDC } \\
\text { was utilized by the various contractors } \\
\text { and KEH staff that provided site } \\
\text { management during construction. }\end{array}$ & $x$ & \\
\hline
\end{tabular}




\begin{tabular}{|c|c|c|c|}
\hline $\begin{array}{l}\text { 3) Review vendor } \\
\text { turnover package with } \\
\text { technical support } \\
\text { staff including the } \\
\text { verification of As- } \\
\text { Built drawings. }\end{array}$ & $\begin{array}{l}\text { Wil Hansen, Brian } \\
\text { Slettene } \\
\text { EDT } 618631 \text { and FDNW ECN } \\
\text { W-112-019 Vendor As- } \\
\text { Built document } \\
\text { submittal and Installed } \\
\text { Design Verification } \\
\text { submittal. }\end{array}$ & $\begin{array}{l}\text { Vendor supplied Professional Engineer } \\
\text { verified documents that both design and } \\
\text { installation for structural, seismic, all } \\
\text { fire system components, electrical and } \\
\text { Tighting, HVAC, plumbing, electrical power } \\
\text { and structural performance met the FDC. }\end{array}$ & $X$ \\
\hline $\begin{array}{l}\text { 4) Review the vendor } \\
\text { open items punchlist } \\
\text { and evidence that they } \\
\text { were properly } \\
\text { dispositioned. }\end{array}$ & $\begin{array}{l}\text { Vendor turnover } \\
\text { package. }\end{array}$ & $\begin{array}{l}\text { The package contained a very informal } \\
\text { punchlist that was noted as complete. } \\
\text { Hats did contain the items and confirmed } \\
\text { that they were tracked to completion }\end{array}$ & $x$ \\
\hline $\begin{array}{l}\text { 5) Review with } \\
\text { technical support } \\
\text { personnel that the } \\
\text { Certified Vendor } \\
\text { Information including } \\
\text { spare parts, was } \\
\text { received, included in } \\
\text { procedures, and } \\
\text { properly dispositioned } \\
\text { for retrieval. }\end{array}$ & $\begin{array}{l}\text { ICF-KHC data } \\
\text { transmittal } \# 0005 \\
\text { "Operations and } \\
\text { Maintenance Manuals }\end{array}$ & $\begin{array}{l}\text { Submittal very complete for all installed } \\
\text { systems and components in the } 2404 \\
\text { buildings that would provide the basis for } \\
\text { preventative and corrective maintenance } \\
\text { and spare parts. }\end{array}$ & $x$ \\
\hline
\end{tabular}




\begin{tabular}{|c|c|c|c|c|}
\hline $\begin{array}{l}\text { 6) Conduct a facility } \\
\text { walkdown with } \\
\text { technical support } \\
\text { personnel to show } \\
\text { evidence that drawings } \\
\text { and other } \\
\text { documentation used is } \\
\text { consistent with the } \\
\text { CWC } 2404 \text { facility. } \\
\text { configuration. }\end{array}$ & $\begin{array}{l}\text { Brian Stellene } \\
\text { As-Built drawing } \\
\text { package for W112 } \\
\text { project. }\end{array}$ & $\begin{array}{l}\text { 1. The as-built field verified drawing } \\
\text { package prepared by Facility Engineering } \\
\text { was of excellent quality. It was field } \\
\text { verified with both the cognizant engineer } \\
\text { and operations staff. This is considered } \\
\text { to be a best practice. } \\
\text { 2. Walkdown included taking the newly } \\
\text { released as-built drawing package and the } \\
\text { redline package that showed the field } \\
\text { updates required. This was essentially an } \\
\text { ECN verification. } \\
\text { 3. System walkdowns: A few systems in } \\
\text { the } 2404 \text { buildings were reviewed in } \\
\text { detail. All but the fire suppression } \\
\text { system were depicted correctly with unique } \\
\text { identifiers. The fire suppression system } \\
\text { did not include system and component } \\
\text { numbers, and the installation appeared to } \\
\text { have some issues with sprinkler heads } \\
\text { being located to close to the building } \\
\text { components and some non-linear sections of } \\
\text { piping. Further discussions with both } \\
\text { maintenance and engineering staff } \\
\text { indicated that Fire System Maintenance } \\
\text { worked totally independent of the CWC } \\
\text { staff and set their own standards of } \\
\text { system performance. }\end{array}$ & $X$ & $x$ \\
\hline
\end{tabular}




\section{PHASE V STORAGE ORR APPRAISAL FORM}

CORE REQUIREMENT:CR 15 The facility systems and procedures as effected by facility modifications, are consistent with the description of the facility, procedures and accident analysis described in the safety basis.

APPROACH:\#6 Review the listing of safety support systems to ensure consistency with the safety basis. This includes defined organizational roles, responsibilities, and interfaces required to comply with the A0SRs.

CRITERIA:\# 7 Utility and support systems are operabie, fuily functional, and meet the performance requirements of the approved safety basis.

\begin{tabular}{|c|c|c|c|c|}
\hline \multirow{2}{*}{$\begin{array}{c}\text { SUBJECT/ACTIVITY } \\
\text { REQUIREMENT REFERENCE }\end{array}$} & \multirow{2}{*}{$\begin{array}{l}\text { EVIDENCE EXAMINED/ } \\
\text { PERSONNEL CONTACTED }\end{array}$} & \multirow[t]{2}{*}{ OBSERVAT IONS/COMMENTS } & \multicolumn{2}{|c|}{ COMPLY } \\
\hline & & & YES & No \\
\hline $\begin{array}{l}\text { 1) Review with the } \\
\text { technical support } \\
\text { personnel that the } \\
\text { performance } \\
\text { requirements of the } \\
\text { CWC } 2404 \text { safety } \\
\text { support systems comply } \\
\text { with the ISB(these } \\
\text { include HVAC, fire } \\
\text { suppression system, } \\
\text { electrical } \\
\text { distribution, monitorin } \\
\text { g instrumentation, and } \\
\text { alarm systems). }\end{array}$ & $\begin{array}{l}\text { Randy Ames, Will Hansen } \\
\text { CWC Master Equipment } \\
\text { List }\end{array}$ & $\begin{array}{l}\text { The ISB only identifies the fire } \\
\text { suppression system and the HVAC } \\
\text { performance requirements. The fire system } \\
\text { is NFPA mandated and is not accounted for } \\
\text { in the accident analysis. The HVAC } \\
\text { provides a specified volumetric change } \\
\text { rate in the buildings, but with the } \\
\text { buildings not providing containment or } \\
\text { confinement there is no safety limits } \\
\text { associated with it. All systems in the } \\
2404 \text { buildings are presented as features } \\
\text { for operation and not part of the nuclear } \\
\text { safety envelope. The technical staff was } \\
\text { very aware and committed to the } \\
\text { operational needs as it relates to these } \\
\text { safety support systems. }\end{array}$ & $x$ & \\
\hline
\end{tabular}




\begin{tabular}{|c|c|c|c|}
\hline $\begin{array}{l}\text { 2)Review the system } \\
\text { testing results from } \\
\text { the systems from (I) } \\
\text { above with the } \\
\text { technical support } \\
\text { staff to assure } \\
\text { performance to the } \\
\text { ISB. }\end{array}$ & $\begin{array}{l}\text { Randy Ames, M Irwin, W } \\
\text { Hansen. }\end{array}$ & $\begin{array}{l}\text { The test results were reviewed by } \\
\text { engineering and issues by EDT to provide } \\
\text { ready availability and formal retention. }\end{array}$ & $x$ \\
\hline $\begin{array}{l}\text { 3) Review with } \\
\text { management the process } \\
\text { used to assure } \\
\text { personnel responsible } \\
\text { for performance and } \\
\text { administration of the } \\
\text { IOSRs and safety basis } \\
\text { compliance are } \\
\text { identified, } \\
\text { knowledgeable, } \\
\text { qual ified. This } \\
\text { includes roles, } \\
\text { responsibilities, and } \\
\text { formal interfaces that } \\
\text { need to be maintained, } \\
\text { both internal and } \\
\text { external. }\end{array}$ & $\begin{array}{l}\text { M Irwin, P Hemsworth P } \\
\text { Crane }\end{array}$ & $\begin{array}{l}\text { CWC management have spent a great deal of } \\
\text { time developing a culture of cooperation } \\
\text { and acceptance of their nuclear and } \\
\text { industrial safety responsibilities. } \\
\text { Personnel with responsibilities for } \\
\text { guiding and administering activities that } \\
\text { related to the safety basis were cognizant. } \\
\text { of their assignment. Roles and } \\
\text { responsibilities were not well documented } \\
\text { nor were the external interfaces. The } \\
\text { operation runs quite well due to the } \\
\text { ownership and dedication of all staff. }\end{array}$ & $x$ \\
\hline
\end{tabular}




\section{PHASE V STORAGE ORR APPRAISAL FORM}

CORE REQUIREMENT:CR 15 The facility systems and procedures as effected by facility modifications, are consistent with the description of the facility, procedures, and accident analysis included in the safety basis.

APPROACH:\#7 Interview personnel associated with configuration management and record storage to assess their understanding of program requirements and responsibilities. This will be reviewed with core requirement CR 8.11-Records Management.

\section{CRITERIA:}

\begin{tabular}{|l|l|l|l|l||}
\hline $\begin{array}{c}\text { SUBJECT/ACTIVITY } \\
\text { REQUIREMENT REFERENCE }\end{array}$ & $\begin{array}{l}\text { EVIDENCE EXAMINED/ } \\
\text { PERSONNEL CONTACTED }\end{array}$ & & OBSERVATIONS/COMMENTS & COMPLY \\
\hline \hline 1$)$ & & & YES & NO \\
\hline 2) & & & \\
\hline
\end{tabular}




\section{PHASE V STORAGE ORR APPRAISAL FORM}

\section{Management 19.1}

CORE REQUIREMENT: The technical and management qualifications of contractor personnel, responsible for facility operations, are adequate.

\section{APPROACH:}

1. Review test material to verify that they adequately reflect training content and test for an understanding of technical fundamentals, procedures, ACs, TSRs, plant activities, and responsibilities associated with emergency response.

2. Review and assess management qualification requirements for adequacy.

3. Review and assess completion of qualifications and test results for management personnel.

\section{CRITERIA:}

2. Adequate documentation of management qualifications is available.

3. Examinations, given to management personnel, are adequate in their depth and breadth of subject matter as it pertains to facility operations.

\begin{tabular}{|c|c|c|c|c|}
\hline \multirow{2}{*}{$\begin{array}{c}\text { SUBJECT/ACTIVITY } \\
\text { REQUIREMENT REFERENCE }\end{array}$} & \multirow{2}{*}{$\begin{array}{l}\text { EVIDENCE EXAMINED/ } \\
\text { PERSONNEL CONTACTED }\end{array}$} & \multirow[t]{2}{*}{ OBSERVATIONS/COMMENTS } & \multicolumn{2}{|c|}{ ACCEPTABLE } \\
\hline & & & YES & NO \\
\hline 1) Review test material. & N/A & Test not given following ISB and new facility briefing. & & \\
\hline $\begin{array}{l}\text { 2) Verify the tests } \\
\text { adequately reflect training } \\
\text { content. }\end{array}$ & $N / A$ & Test not given. & & \\
\hline $\begin{array}{l}\text { 3) Verify the tests } \\
\text { adequately test for an } \\
\text { understanding of technical } \\
\text { fundamentals, procedures, ACs, } \\
\text { TSRs, plant activities, and } \\
\text { responsibilities associated } \\
\text { with emergency response. }\end{array}$ & N/A & Test not given. & & \\
\hline
\end{tabular}




\begin{tabular}{||l|l|l||}
\hline $\begin{array}{l}\text { 4) Review management } \\
\text { qual ification requirements for } \\
\text { adequacy. }\end{array}$ & $\begin{array}{l}\text { Reviewed Position Descriptions } \\
\text { and qual ification requirements } \\
\text { in training file. }\end{array}$ & Position requirements are adequate. \\
\hline $\begin{array}{l}\text { 5) Review completion of } \\
\text { qual ifications and test } \\
\text { results for managenent } \\
\text { personnel. }\end{array}$ & N/A & None required. \\
\hline
\end{tabular}




\section{PHASE V STORAGE ORR APPRAISAL FORM}

\section{Management 19.2}

CORE REQUIREMENT: The technical and management qualifications of contractor personnel, responsible for facility operations, are adequate.

\section{APPROACH:}

4. Conduct interviews to determine the extent of knowledge of technical fundamentals, procedures, ACs, plant activities, and responsibilities associated with emergency response.

\section{CRITERIA:}

1. Management has adequate on-the-job experience and/or training/education that qualifies them for their positions.

\begin{tabular}{|c|c|c|c|c|}
\hline \multirow{2}{*}{$\begin{array}{c}\text { SUBJECT/ACTIVITY } \\
\text { REQUIRENENT REFERENCE }\end{array}$} & \multirow{2}{*}{$\begin{array}{l}\text { EVIDENCE EXAMINED/ } \\
\text { PERSONNEL CONTACTED }\end{array}$} & \multirow[t]{2}{*}{ OBSERVATIONS/COMMENTS } & \multicolumn{2}{|c|}{ ACCEPIABLE } \\
\hline & & & YES & NO \\
\hline $\begin{array}{l}\text { 1) Interview CWC management, } \\
\text { including senior management, } \\
\text { responsible for operating the } \\
\text { CWC. }\end{array}$ & $\begin{array}{l}\text { S. Addleman } \\
\text { P. Crane } \\
\text { P. Brannan }\end{array}$ & $\begin{array}{l}\text { Team Lead, Environmental } \\
\text { Manager, Operations } \\
\text { Manager, Radiological controls }\end{array}$ & & \\
\hline $\begin{array}{l}\text { What qual ification or } \\
\text { certification enables you to } \\
\text { hold your position? }\end{array}$ & $" 1$ & $\begin{array}{l}\text { Managers hold technical degrees, have obtained specialized } \\
\text { certifications, have completed training, and have relevant } \\
\text { experience appropriate to their present assignment. }\end{array}$ & $x$ & \\
\hline $\begin{array}{l}\text { Describe previous management } \\
\text { and technical assignments } \\
\text { where you had responsibility } \\
\text { for storing and managing } \\
\text { radiological, dangerous, and } \\
\text { mixed waste materials. }\end{array}$ & $"$ & $\begin{array}{l}\text { Personnel interviewed described previous assignments } \\
\text { appropriate to their present assignment, including } \\
\text { experience in hazardous material management and in other } \\
\text { Hanford factlities (Tank Farms, PUREX, PFP). }\end{array}$ & $x$ & \\
\hline $\begin{array}{l}\text { What are the characteristics } \\
\text { of concern for personnel } \\
\text { safety and environmental } \\
\text { protection in the waste } \\
\text { materials stored in the CWC? }\end{array}$ & 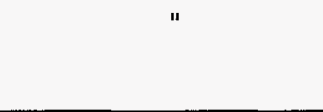 & $\begin{array}{l}\text { Characteristics discussed included hazardous materiats and } \\
\text { carcinogens. Issues of concern are inhalation of and } \\
\text { contanination resulting from these materials. }\end{array}$ & $x$ & \\
\hline
\end{tabular}




\begin{tabular}{|c|c|c|c|}
\hline $\begin{array}{l}\text { What accidents or events in } \\
\text { the chc might require } \\
\text { emergency response action? }\end{array}$ & " & $\begin{array}{l}\text { Accidents or events described include spills, fork truck or } \\
\text { crane material handling event, container breach, dropped } \\
\text { container. }\end{array}$ & $x$ \\
\hline $\begin{array}{l}\text { Describe your role and } \\
\text { responsibility in energency } \\
\text { response? }\end{array}$ & " & $\begin{array}{l}\text { Roles described include consult and advise for } \\
\text { environmental and personnel protection cleanup, and } \\
\text { decon; Building Emergency Director; Facility Management; } \\
\text { Radcon advisor. }\end{array}$ & $x$ \\
\hline $\begin{array}{l}\text { How can the chl be operated } \\
\text { and managed to prevent or } \\
\text { mitigate reduced personnel } \\
\text { safety and loss of } \\
\text { enviromental protection? }\end{array}$ & " & $\begin{array}{l}\text { Maintain operator and supervisor knowledge levels high. } \\
\text { Cont inue frequent and timely safety meetings, emphasize MOP } \\
\text { tours, conduct innovative training (fork truck rodeo). }\end{array}$ & $x$ \\
\hline $\begin{array}{l}\text { Who has the final } \\
\text { responsibility for safety in } \\
\text { the CWC? }\end{array}$ & " & $\begin{array}{l}\text { Each individual is responsible for his or her own safety. } \\
\text { Management is responsible for safety in the facility. }\end{array}$ & $x$ \\
\hline
\end{tabular}




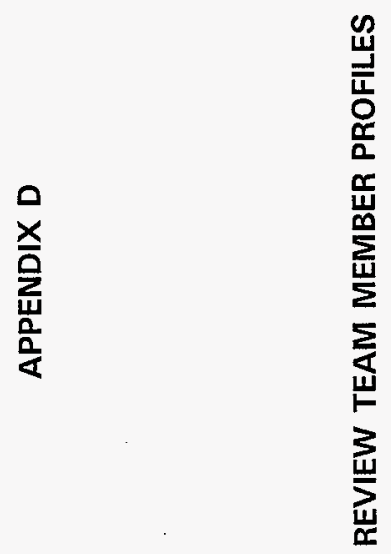




\section{CWC Project W-112/ISB ORR Review Team Member Profiles}

NAME:

Richard E. Allen

SPECIALTY: $\quad$ Emergency Preparedness

EXPERIENCE: $\quad 16$ years of professional experience in environmental regulations and emergency preparedness. Presently the emergency preparedness coordinator for T Plant. Write and perform drills, review and revise emergency manual and guide, readiness review team member for other facilities.

NAME:

Annette E. Aughey

SPECIALTY: $\quad$ Operations / Administrative

EXPERIENCE: $\quad 14$ years experience as a Nuclear Process Operator. Currently a Solid Waste Requirements (SRIDS) expert as wel1 as the administrator of the WHC-CM-5-36 manual. Participation on the ORR team will be to evaluate the usefulness of the procedures from a users point of view and coordination of the ORR team results.

NAME:

James R. Barber

SPECIALTY: Maintenance

EXPERIENCE: $\quad 28$ years experience in Electronics, Instrumentation \& Controls. With the last six years spent Planning, developing, coordinating and administrating site-wide assessment of technical procedures. Provided administration of hanford site maintenance procedure program. Developed administrative manuals implementing DOE Orders 5480.19 , "Conduct of Operations...", and 4330.4B, "Maintenance Management Program."

NAME:

William W. Bowen

SPECIALTY:

Operations/ Management / Security

EXPERIENCE: $\quad 29$ years experience in management, construction, start up, and operation of nuclear and chemical plants in both commercial and government environments. BS, MS Mechanical Engineering 
NAME: Samuel J. Dechter

SPECIALTY: Management Systems

EXPERIENCE: $\quad$ Over 30 years management and engineering experience of which 20 years was spent in management with various DOE GOCO Site. BS and MS in Physics, has qualified as EOOW, NPE and Shift Supervisor.

NÂHE:

John I. Gould

SPECIALTY: Environmental Compliance

EXPERIENCE: $\quad 30$ years experience in Environmental Compliance reviewing, analysis, planning and field investigation, for regulatory compliance in hazardous environments, in both the private and DOE sectors. MS- Physics Minors in Engineering mathematics/Atmospheric Physics, BS Environmental Compliance.

NAME:

John A. Locklair, Jr.

SPECIALTY:

Nuclear Safety

EXPERIENCE:

12 years experience in Nuclear Safety and Health Physics in both commercial and Department of Energy. Also responsible for review and publication of Safety Basis documents. BS Geophysics

NAME:

Kenneth W. McLain

SPECIALTY: Radiological Control

EXPERIENCE: $\quad 14$ year experience in operational Health Physics at commercial nuclear and Department of Energy sites. Current assignment includes implementation of 10 CFR 835 and coordinating the RFSH response to Enforcement Action EA-96-02.

NAME:

Richard B. Millward 
SPECIALTY:

EXPERIENCE:

NAME:

SPECIALTY: $\quad$ Operations and Management

EXPERIENCE:

NAME:

SPECIALTY:

EXPERIENCE:

NAME:

SPECIALTY:

EXPERIENCE:

NANE:

SPECIALTY:

Quality Assurance

Timothy J. Powel1

Rodney D. Pickett

Conduct of Operations Certified Shift Manager.

Thomas C. Stone

Industrial Safety/Hygiene

Shelby J. Turner

Operations, Safety
25 years in the Quality Assurance field including roles ranging from QC inspector, QA engineer, Lead Auditor and Manager.

23 years experience in construction, start-up, operation, oversight, training and maintenance in commercial nuclear power and Department of Energy (DOE) activities. Recently, Mr. Powell provided four (4) years of program support to DOE at Hanford, working at the Director level in the Waste Programs Division (this support included participation as a team member on two (2) DOE-RL Operational Readiness Reviews).

Six years experience in design and operation of power distribution, plant parameter monitoring and control equipment, pneumatics, piping/plumbing. BS Electrical Engineering,

20 years experience in the Safety and Health Field, including marine construction, a large telephone company. Was al so Safety Manager at WPPSS. Plant \#2 while it was under construction. BA in Geography and a BS in Occupational Safety and Health. 
EXPERIENCE:

SPECIALTY:

EXPERIENCE:

NAME:

SPECIALTY:

EXPERIENCE:

NAME:

SPECIALTY:

EXPERIENCE:
28 years working in operations and oversight of naval reactors programs and DOE facilities including participation on the DOE INEL tiger Team assessment and lead auditor for contractor reviews. Responsible for reviewing Nuclear and Industrial safety, Conduct of Operations. and maintenance.

Ronald H. Wight

Assistant Team Leader

15 years experience in commercial and nuclear environments as industrial safety specialist. Experience as safety engineer in Research and development, startup, and established facilities. Certified lead auditor, and Certified Associate Safety Professional ASP.

Charles J. Wolfe

Team Leader

19 years in the nuclear field encompassing training, qualification and operation of nonnuclear, nuclear, and nuclear reactor facilities, have experienced the challenges of restarting the Rocky Flats Weapons Plant. Established and monitored the implementation o the Rust Geotech Compliance Management System including Readiness Reviews and Conduct of Operations. The most recent responsibility was the development and implementation of a transition methodology that provided for the identification through resolution of all transition and contract close-out issues for Rust Geotech Inc., in Grand Junction, Co.

Mike T. York

Engineering

18 years experience in Engineering, project and program management dealing with facility operations and multi - facility monitoring systems. BS Nuclear Engineering, BS Business Administration. 
N

용

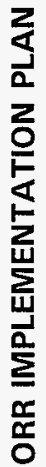


OPERATIONAL READINESS REVIEW IMPLEMENTATION PLAN (IP)

\author{
PROJECT W-112 - PHASE V STORAGE BUILDINGS \\ CENTRAL WASTE COMPLEX
}




\section{DISCLAIMER}

This Operational Readiness Review Implementation Plan (ORRIP) was written in accordance with WHC-CM-5-34, "Solid Waste Disposal Operations Administration" Section 1.4, "Operational Readiness Activities". The ORRIP has been issued as a controlled document. 


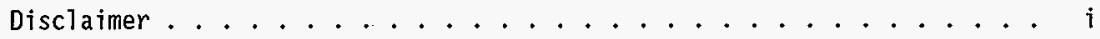

Acronyms and Abbreviations ................... i i

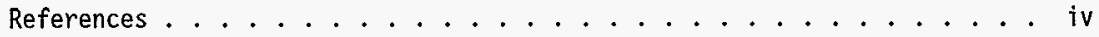

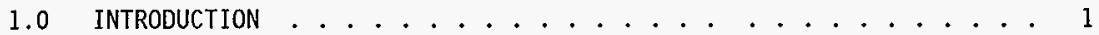

$1.1 \quad$ General Facility Description . . . . . . . . . . . 1

1.2 Facility Readiness ................. 1

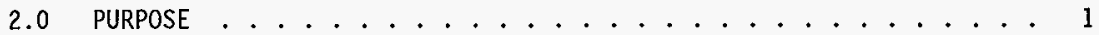

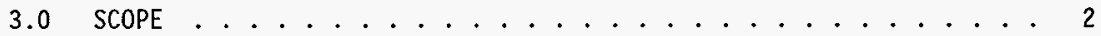

4.0 ORR PREREQUISITES .................. 3

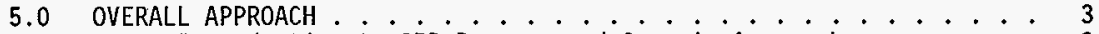

5.1 Introduction to ORR Process and Generic Approach . . . . . 3

5.2 Finding Resolution and Closure Method ......... 4

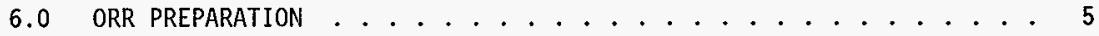

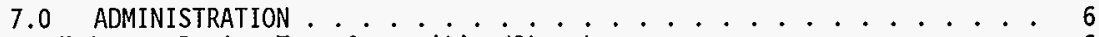

7.1 Review Team Composition/Structure ........... 6

7.2 Meetings ............... 6

7.3 Correspondence, Communication and Interface . . . . . 6 6

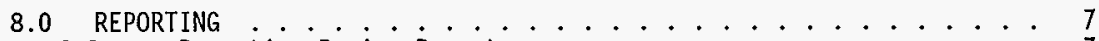

8.1 Reporting Review Reports ............. 7

8.2 Orr Report Issuance ............... 8

8.3 Post-0RR Presentations .............. 8

9.0 SCHEDULE .................. 8

APPENDIX A: ORR PREREQUISITE CHECKLIST

APPENDIX B: CRITERIA AND REVIEW APPROACHES

APPENDIX C: ORR FORMS

APPENDIX D: FINDING CLASSIFICATION CRITERIA

APPENDIX E: OPERATIONAL READINESS REVIEW REPORT FORMAT 


\section{ACRONYMS AND ABBREVIATIONS}

$\begin{array}{ll}\text { AC } & \text { Administration Control } \\ \text { ALARA } & \text { As Low As Reasonably Achievable } \\ \text { ATP } & \text { Acceptance Test Procedure } \\ \text { CAP } & \text { Corrective Action Plan } \\ \text { CFR } & \text { Code of Federal Regulations } \\ \text { CH } & \text { Contact-Handled } \\ \text { CO0 } & \text { Conduct Of Operations Department } \\ \text { CPS } & \text { Critical ity Prevention Specification } \\ \text { CRAs } & \text { Criteria and Review Approaches } \\ \text { CSER } & \text { Criticality Safety Evaluation Report } \\ \text { CWC } & \text { Central Waste Complex } \\ \text { DNFSB } & \text { Defense Nuclear Facilities Safety Board } \\ \text { DOE } & \text { Department Of Energy } \\ \text { ECN } & \text { Engineering Change Notice } \\ \text { HATS } & \text { Hanford Action Tracking System } \\ \text { IP } & \text { Implementation Plan } \\ \text { ISB } & \text { Interim Safety Basis } \\ \text { LCO } & \text { Limiting Condition of Operation } \\ \text { ORR } & \text { Operational Readiness Review } \\ \text { ORRIP } & \text { ORR Implementation P1an } \\ \text { OSHA } & \text { Occupational Safety and Health Administration } \\ \text { OSR } & \text { Operational Safety Requirement } \\ \text { OTP } & \text { Operational Test Procedure } \\ \text { PM } & \text { Preventive Maintenance } \\ \text { PMT } & \text { Post Maintenance Teasing } \\ \text { POA } & \text { Plan-of-Action } \\ \text { RFSH } & \text { Rust Federal Services Hanford } \\ \text { RIDS } & \text { Records Inventory Disposition Schedule } \\ \text { RT } & \text { Review Team Leader } \\ \text { RTL } & \text { Review Team Leader } \\ \text { RWP } & \text { Radiation Work Permit } \\ \text { S/RID } & \text { Standards/Requirements Identification Document } \\ \text { TRU } & \text { Transuranic } \\ \text { TSR } & \text { Technical Safety Requirement } \\ \text { VPWM } & \text { Vice President Waste Management Organization } \\ \text { WAC } & \text { Washington State Administrative Code } \\ & \\ \end{array}$




\section{REFERENCES}

1) WHC-IP-1120, Rev 4, Standards/Requirements Identification Document (SRIDS)

2) WHC-CM-5-36, SWD Interna7 Requirements

3) WHC-CM-5-34, Solid Waste Disposal Operations Administration

4) WHC-IP-1048, Operationa7 Readiness Activities

5) HNF-SD-WM-ISB-007, Central Waste Complex Interim Safety Basis

6) HNF-SD-WM-PLN-124, Rev. 0 P7an-Of-Action For Phase V Storage Operational Readiness Review

7) DNFSB RECOMMENDATION 90-2 REQUIREMENTS INFORMATION DOCUMENT

8) RL-ID-5480.31, Startup and restart of Nuclear Facilities

9) DOE-STD-3006-93, P7anning and Conduct of Operational Readiness Reviews

10) ECN 164059, Phase V Storage Functiona7 Design Criteria 


\subsection{INTRODUCTION}

\subsection{General Facility Description}

The Phase V Storage buildings are located in the 200 West Area Central Waste Complex (CWC) and are bounded by Dayton Avenue, 23rd Street, and 16th Street. Phase V Storage consists of three Long-Term Drum Storage buildings that will provide 13,300 drum equivalent of radioactive and mixed solid waste storage space. Construction is similar to existing CWC structures. Contact-Handied (CH) wastes from onsite and offsite generators are to be stored. Waste will include Low-Level Greater than Category 3, Mixed Low-Level, Transuranic (TRU), Suspect TRU, TRU Mixed, and remote-handled waste shielded down to CH packages. The storage area will be capable of receiving and accommodating 208-1iter (55gallon) and/or 322-7iter (85-gallon) palletized drums stacked up to three high, and other waste packages such as steel boxes.

The design utilized manual waste storage and waste package transport concepts (e.g., palletized containers and forklift transport) to safely and compliantly store solid waste. The storage area will be accessible to appropriate drum and/or pallet moving equipment. The facility is equipped with a fire suppression system, 120 volt and 480 volt electrical system, telephone, sanitary/raw water system, freeze protection, new and/or upgraded access roads, sidewalks, fencing, fire alarm system, radio fire alarm reporter, exhaust ventilation, nonisokinetic record samplers, ventilation, and fire detection interlocks, portable fire extinguishers, sloped epoxy coated floors, 1iquid collection curbing and/or catch basins, personnel doors, roll-up doors, lighting, and emergency lighting.

\subsection{Facility Readiness}

Prior to performance of the Operational Readiness Review (ORR), the facility will conduct a Readiness Self-Assessment to ensure facilities, equipment, personne1, procedures, and management control systems are in place to operate safely, efficiently, and in compliance with all applicable requirements. After satisfactory completion of the facility self-assessment, the Solid Waste Management Facility Manager will declare readiness to the ORR Review Team Leader (RTL) who will initiate the Rust Federal Services of Hanford, Inc., (RFSH) ORR.

The CWC facility personnel will support the ORR Review Team (RT) by providing al1 documentation that substantiates facility readiness, access to the facility and personneT, adequate accommodations to perform the ORR, and by performing drills and operations requested by the RT.

\subsection{PURPOSE}

The purpose of this review is to ensure facilities, equipment, personnel, procedures, and management control systems are in place to operate the new storage buildings in the CWC, under the new authorization basis, in a safe, efficient, and compliant manner.

\subsection{SCOPE}

The Phase $V$ Storage (Project $W-112$ ) was constructed to provide additional mixed solid waste storage space in the CWC to store containers prior to 
processing and/or treatment. The CWC is operated by RFSH, Solid Waste Management organization. The $W-112$ project included infrastructure work, a maintenance trailer supporting the Waste Receiving and Processing Plant (WRAP), and a support trailer supporting WRAP, as well as the three Phase $V$ storage buildings. The WRAP trailers are in operation and will not be included in the scope of the ORR for the Phase $V$ Storage buildings.

Therefore, subsequent reference to Project $W-112$ will only be in relation to the three additional storage buildings, 2404 Series, to be incorporated into the CWC.

The CWC Phase $V$ Storage buildings are a modification to an existing facility (CWC). The current and approved CWC safety basis is HNF-SD-WM-ISB-007, Central Waste Complex Interim Safety Basis (ISB), which incorporates new facility inventory limits affecting all CWC storage buildings. The changes imposed by HNF-SD-WM-ISB-007 consist of adding the three buildings to the CWC, increasing inventory limits, and upgrading the accident analys is to be consistent with waste distribution. The ISB documents the CWC as a preliminary Hazard Category 2, based on a facility radiological inventory and threshold quantities of DOE-STD-1027-92. Startup of a modification made to a Hazard Category 2 Nuclear Facility (CWC) with a corresponding change to the safety basis, requires performance of an Operational Readiness Review (ORR) per WHC-CM-5-34, Solid Waste Disposal Operations Administration, Section 1.4, Operational Readiness Activities. Approval Authority has been determined to be the U.S. Department of Energy, Richland Operations office (RL) OPS Office Manager. The Review Type and Approval Authority are commensurate with the facility's potential impact on safety and its planned conduct of operations.

The Phase $V$ Storage buildings operation is an add-on to the existing facility operations. Therefore, a graded approach will be used for the completion of the ORR. The scope of this ORR is the following:

1. Ensure that the facility structure, systems, and components are adequately installed and function as designed, and

2. Ensure the new ISB requirements are administratively incorporated into al1 phases of facility operations. The breadth of the ORR is to ensure that the new Phase $V$ Storage bujldings are operated in accordance with the ISB requirements for nuclear criticality and radionuclides inventory control.

The following areas have been identified as areas that will need to be reviewed during the ORR. Specifics on the scope are contained in Appendices $A$ and $B$.

- Construction of the facility in accordance with drawings and specifications

- Grading and facility access in accordance with drawings and specifications

- Utilities, supplied connections, and operational status of air, water, and electrical power distribution

- Approved operating, maintenance, and support procedures

- Operating, maintenance, and support personnel training and qualifications 
- Safety monitoring and fire protection equipment and systems

- Approved Criticality Prevention Specification

- Radiological controls in place (e.g., Radiological Work Permits, ALARA review, etc.)

- Safety documentation adequate to support facility operation

- Administrative procedures modified to include 2404 Series facilities

- Organization structure adequate to support facility operations

- Modified safety basis Timits

- Emergency preparedness.

\subsection{ORR PREREQUISITES}

Prior to the commencement of the ORR, RFSH Conduct of Operations (COO) personnel and/or select RT members will conduct a check of a11 prerequisites to ensure they are completed (see Appendix A). Determinations as to the adequacy (readiness) of prerequisite items for actual startup will be evaluated during review performance.

\subsection{OVERALL APPROACH}

\section{I Introduction to ORR Process and Generic Approach}

The ORR will be performed per WHC-CM-5-34, Solid Waste Disposal Operations Administration, Section 1.4, Operational Readiness Activities. The overal1 ORR process consists of the following basic steps:

- Review Team Leader (RTL) will be assigned by the Vice President Waste Management Operations (VPWMO).

- Plan of Action (POA) is written by the facility to formalize the decisions necessary to execute a new start. The POA will be provided through Flour Daniel Hanford (FDH) to DOE-RL for review, comment, and approval.

- Implementation Plan (IP) is drafted based on the DOE RL approved POA.

- RTL selects personnel to be members of the RT.

- As the facility performs actions to obtain readiness, the RT will review and provide comments to the IP; perform required reading, training, and facility familiarization.

- The facility will declare readiness in writing to the RTL.

- Upon verification of all prerequisite completion, the RT will commence the ORR. The RT will conduct a performance based ORR consisting of documentation review, observation of facility operations and drills, personnel interviews, and facility/equipment hand-over-hand inspections. The RT wil1 use the Criteria and Review Approaches (CRAs) of Appendix B 
when performing the review. The CRAs were developed to include the Core Requirement, Criteria, Review Approach, Basis, and References.

- The RT will prepare and distribute the final ORR Report (see section 5.2) with all Findings classified as either prestart or post-start (see Appendix D for Finding Classification Criteria)

- The facility will determine and perform corrective actions to resolve RT Prestart Findings (see section 5.3).

- After satisfactorily completing Prestart Findings, the facility will issue a Readiness to Proceed Memorandum to DOE RL.

- DOE RL will perform their review and present Findings to the facility.

- The facility will determine and perform corrective actions to resolve DOE Prestart Findings.

- After satisfactorily resolving Prestart Findings, DOE RL will authorize startup of the facility.

- Facility resolve Post-start Findings.

\subsection{Finding Resolution and Closure Method}

Facility management will prepare Corrective Action Plans (CAPs) which address the Findings. The RT and RTL will be available to support facility management in review and closeout of findings as necessary. The CAP for each Finding should contain the following elements:

a. The Finding, as written in the ORR report submitted by the RT, and whether the Finding is a Prestart or Post-start Finding.

b. The actions shall address the deficiencies identified in that Finding. The actions shall provide evaluation of any overall programmatic deficiencies or root causes related to a specific Finding which may lead to further similar occurrences and include actions addressing such deficiencies or root causes.

c. The proposed dates by which the actions will be completed. If the actions for a Finding are phased, then the dates for each phase shall be detailed.

d. For Post-start Findings, a description of the risks and mitigating actions, if any, to be taken during the interim which will reduce the risks associated with the Finding to an acceptable level before final correction. Include justification that the activity can proceed with acceptable risk.

\subsection{ORR PREPARATIONS}

The RTL will select the RT members. RT members should have the following verified qualifications:

- Technically knowledgeable in the area assigned to evaluate. The knowledge should include experience working in the technical area. 
- Knowledge of evaluation processes and methods. This knowledge may be gained through experience as an auditor or inspector or it may be gained through training evaluated as acceptable by the RTL.

- Facility specific information which may be gained through a combination of required reading and facility tours and presentations.

- Independence. RT members (including the RTL) will not be individuals who are assigned direct line management responsibilities for the work being reviewed and RT members shall not review his or her own work or work for which they are directly responsible.

RT members will be required to perform or have previously performed facility familiarization (through tours, presentations, and provided documentation), required reading, and specific training. RT members will be provided facility documentation (operating procedures, emergency response procedures, permits, FDCs, etc.) prior to commencement of ORR as training material to gain facility specific knowledge. Tours and presentations will be coordinated between the facility and RTL. The RT members will be required to take or have taken applicable site and facility training to gain access to the facility. Prior to review performance, the RTL or designee will prepare and stage review forms, ORR Report she17, and any other report material which will allow an efficient review performance.

\subsection{ADMINISTRATION}

\subsection{Review Team Composition/Structure}

The RT is comprised of the RTL and a number of members who are divided amongst the Core Requirements. An RT member may be assigned to one or more Core Requirements depending on need and qual ifications. An RT member assigned to a Core Requirement may solicit input of other RT members or experts as seen fit to adequately evaluate a Core Requirement. An expert is not part of the RT but an individual who has an in depth knowledge of a very specific item.

RT members will be knowledgeable and have experience in the various areas of review (e.g., safety, quality assurance, environmental protection, engineering, operations, etc.). RT members will be determined by the RTL.

\subsection{Meetings}

To facilitate RT coordination and the exchange of information, the RT will meet regularly. Prior to the review, RT members will meet to participate in orientation, training, required reading, IP review, and facility tours and presentations. During the review, RT members will meet daily for debriefs. Facility personnel and management will be invited to these debriefs. These meetings will permit the RT members to discuss observations, potential Findings, actual Findings, problems encountered during review, additional information required, additional time required, schedules etc. Meetings will also permit the RTL to identify any trends or areas where more detailed information may be required. The RTL will use these meetings to review the efforts of the RT members to assure all Core Requirements are thoroughly assessed and that approaches used are in accordance with the CRAs. It will also allow potential schedule difficulties or possible information gaps to be noted in time to take corrective actions. During the review, designated RT 
members will also meet daily with the facility to discuss potential Findings, actual Findings, next day events, schedule problems, conflicts, additional information, etc.

\subsection{Correspondence, Communication and Interface}

Communication is a key aspect to proper ORR performance. Communication, both written and oral, is vital between facility, RT, and DOE as well as between RT members. To facilitate ORR performance, the facility will appoint a single point of contact to interface with the RT and DOE. Likewise the RT will have a single point of contact, to interface with the facility and DOE. The points of contact are responsible for coordinating meetings, evolutions/operations observations, interviews, needed documentation and for expressing concerns of both facility and RT. The RT is to be diligent in its thorough documentation of appraisals and Findings. RT Findings will be proof read for clarity, accuracy, and preciseness by other RT members prior to facility management exposure or submittal to final report. Meeting Minutes will be taken and distributed if warranted (e.g., poor meeting attendance, closeout meeting, extreme meeting interest, etc.)

\subsection{REPORTING}

\subsection{Reporting Review Results}

The ORR Report must be clear as to what was evaluated and the methodology used during the evaluation (review logic). To ensure clarity and consistency, standard forms will be used by all RT members. Standard Forms are contained in Appendix $C$ and consist of the following: ORR Appraisal Form, ORR Finding Form, and ORR Observation Form. There is no specific form for Finding Resolutions but they will be tracked by the facility until they are appropriately closed.

An ORR Appraisal Form or line of inquiry will be used to document each Criteria evaluation. The form will be used to document personnel contacted, documentation reviewed, evolutions/operations witnessed, areas visited and a summary/comment of the review.

An ORR Finding Form will be used for each Finding noted. A new form will be used for each new Finding. A Finding is considered an item that is not in agreement with contractual requirements or if not corrected could have an adverse impact on the environment, personnel, or the public. (See Appendix D for further detail on classification of a finding) An Observation on the other hand is an item which does not fall within the bounds of a finding but if corrected would improve overall performance. ORR Finding Forms will document the Finding by providing the requirement(s) deviated, reference(s), and a discussion, conclusion, and resolution section. The ORR Observation Form will be used to document all Observations noted during the review.

All forms shoutd be complete and in enough detail to allow an outside agency reviewing the form to follow the review logic and means utilized to verify. performance with respect to the criterion and to thereby validate the completeness and adequacy of the ORR. If for some reason the intent of a Criterion cannot be achieved, the reason should be documented. 
Al1 Findings will be evaluated for similarities, overlap, and duplication. Findings which are duplicate or overlap will be combined into a singular Finding and similar Findings will be grouped. These grouped Findings will make up the Master Findings List. The compilation of Master Findings will be evaluated by the RT to determine if they qualify as either a prestart or poststart Finding (per Appendix D).

Any RT member is free to issue a dissenting opinion, which will be carefully considered. Every attempt will be made to resolve the issue during the course of the review. However, should resolution not be achieved, provisions will be made to include the dissenting opinion in the ORR report.

The RTL will review the Findings List and develop an ORR report to document the results of the ORR and to provide justification for the RT's recommendations. ATI ORR Appraisal Forms or Lines of Inquiry, ORR Finding Forms, ORR Observation Forms, and the Findings List will be included in the ORR report to provide the review logic. Core Requirement leaders will be asked to sign findings and observations, signifying their agreement in report content and conclusion in the area they were assigned. Dissenting opinions that have not been resolved will be appropriately addressed in the ORR report.

The RTL will report any problems or successes and document them as Lessons Learned to aid future ORRs. These should include Lessons Learned with respect to the ORR process, as well as any Lessons Learned regarding the design, construction, and/or decommissioning of DOE nuclear facilities.

\subsection{ORR Report Issuance}

Copies of the ORR report will be transmitted by the RTL to the VPWMO and to the facility manager. The original ORR report will be entered into Records Inventory Disposition Schedule (RIDS) by RFSH-COO.

\subsection{Post-0RR Presentations}

The RTL will coordinate any follow-up meetings, which include closeout meetings with the facility's management, debriefings of the RT, and presentation of the ORR report to upper management. Presentations may be required to internal or external interested groups as well.

\subsection{SCHEDULE}

The following is a proposed schedule that will be more firmly established prior to the ORR commencement date.

\begin{tabular}{|l|l|}
\hline Date & Action \\
\hline $\begin{array}{l}\text { up to April 14, } \\
1997\end{array}$ & Convene Team and prepare for ORR. (issue IP) \\
\hline February 1, 1997 & $\begin{array}{l}\text { Facility commence internal readiness reviews, } \\
\text { affidavits. }\end{array}$ \\
\hline May 6, 1997 & Commence 0RR. \\
\hline May 9, 1997 & Conclude ORR and commence ORR report. \\
\hline
\end{tabular}




\begin{tabular}{||l|l|}
\hline May 13,1997 & Initiate report release. \\
\hline May 14, 1997 & Facility develop Corrective Action Plan. \\
\hline May 20, 1997 & Facil ity complete Corrective Action Plan. \\
\hline
\end{tabular}




\section{APPENDIX A: PHASE V STORAGE ORR}

\section{PREREQUISITE CHECKLIST}

PHASE V STORAGE ORR IMPLEMENTATION PLAN

HNF-SD-WM-IP-011, Rev, 0 Page AI 


\section{Phase V Storage Operational Readiness Review \\ Prerequisite Checklist \\ Core Requirement 1}

There are adequate and correct procedures and safety limits for operating the process systems and utility systems.

Are the following prerequisites approved, in place, and ready for review?

- 1) Operating procedures

- 2) Maintenance procedures

- 3) Emergency operating procedures/alarm response procedures

The prerequisites for Core Requirement 1 appear to have been met and are ready for ORR commencement.

\section{Signatures:}

Group Leader / Team Member(s):

\section{Core Requirement 2}

Training and qualifications programs for operations and operations support personnel have been estabTished, documented, and implemented (the training and qualification program encompasses the range of duties and activities required to be performed).

Are the following prerequisites approved, in place, and ready for review?

1) Operations and maintenance personnel training records.

2) Training and qualification program (e.g., training material, OJT Check Sheets, Job Performance Measures, test material, training aids, etc.)

3) Criticality safety training

4) Operating procedures training

5) Administrative procedures

The prerequisites for Core Requirement 2 appear to have been met and are ready for ORR commencement.

\section{Signatures:}

Group Leader / Team Member(s):

\section{Core Requirement 3}

Level of knowledge of operations and operations support personnel is adequate based on reviews of examinations and examination results and selected interviews of operating and operations support personnel. 
Are the following prerequisites approved, in place, and ready for review?

- 1) List of CWC operations and support personne1

- 2) List of operations and operations support personne 1

The prerequisites for Core Requirement 3 appear to have been met and are ready for ORR commencement.

Signatures:

Group Leader / Team Member(s):

\section{Core Requirement 4}

Facility safety documentation is in place that describes the "safety envelope" of the facility. The safety documentation should characterize the hazards/risks associated with the facility and should identify mitigating measures (systems, procedures, administrative controls, etc.) that protect workers and the public from those hazards/risks. Safety systems and systems essential to worker and pubiic safety are defined and a system to maintain control over the design and modification of the facilities and safety-related utility systems is established.

Are the following prerequisites approved, in place, and ready for review?

- 1) Interim Safety Basis

2) Fire Hazards Analysis

3) Radiation protection program

4) Operational safety requirements

The prerequisites for Core Requirement 4 appear to have been met and are ready for ORR commencement.

\section{Signatures:}

Group Leader / Team Member(s):

\section{Core Requirement 5}

A program is in place to confirm and periodically reconfirm the condition and operability of safety systems, including safety related. process systems and safety related utility systems. This includes examinations of records of tests and calibrations of operation or that satisfy Technical Safety Requirements. All systems are currently operable and in a satisfactory condition.

Are the following prerequisites approved, in place, and ready for review?

1) Operational Acceptance Test Procedures and results 
2) Records of safety related system testing

The prerequisites for Core Requirement 5 appear to have been met and are ready for ORR commencement.

Signatures:

Group Leader / Team Member(s):

\section{Core Requirement 6}

A process has been established to identify, evaluate, and resolve deficiencies and recommendations made by oversight groups, official review teams, audit organizations, and the operating contractor.

Is the following prerequisite approved, in place, and ready for review?

1) Corrective action plan that was developed from the FEB review of Solid Waste Management performed in December, 1996.

The prerequisite for Core Requirement 6 appears to have been met and is ready for ORR commencement.

\section{Signatures:}

Group Leader / Team Member(s):

\section{Core Requirement 7}

A systematic review of the facility's conformance to applicable DOE orders has been performed, any nonconformance have been identified, and schedules for gaining compliance have been justified in writing and formally approved.

Is the following prerequisite approved, in place, and ready for review?

1) The approved Waste Management SRID (which includes CWC [Phase V Storage])

The prerequisites for Core Requirement 7 appear to have been met and are ready for ORR commencement.

\section{Signatures:}

Group Leader / Team Member(s):

\section{Core Requirement 8}

Management programs are established, sufficient numbers of qualified personnel are provided, and adequate facilities and equipment are available to ensure operational support services (e.g., training, maintenance, waste management, environmental protection, industrial safety and hygiene, radiological protection and health physics, emergency preparedness, fire protection, quality assurance, criticality safety, and engineering) are adequate for operations. 
Are the following prerequisites approved, in $\mathrm{place}$, and ready for review?

- 1) Maintenance procedures

2) Management assessment program

3) Preventive maintenance and evaluation program

4) Calibration program

5) Radiation safety programs

6) Emergency preparedness program and procedures

7) Environmental Compliance assessment

8) Quality assurance program

9) HAZCOM program

10) Health and safety plan

11) Baseline hazard assessment

12) Management Self-Assessment of Phase $V$ Storage Facilities

The prerequisites for Core Requirement 8 appear to have been met and are ready for ORR commencement.

\section{Signatures:}

Group Leader / Team Member(s):

\section{Core Requirement 9}

A routine and emergency operations drill program, including program records, has been established and implemented.

Are the following prerequisites approved, in place, and ready for review?

- 1) Records and audits of dritls

- 2) Emergency operations and response training records

- 3) Emergency operation and drill program

The prerequisites for Core Requirement 9 appear to have been met and are ready for ORR commencement.

\section{Signatures:}

Group Leader / Team Member(s): 
An adequate start up or restart test program has been developed that includes adequate plans for graded operations testing to simultaneously confirm operability of equipment, the viability of procedures, and the training of operators. .

This core requirement will not be reviewed because the addition of the additional storage buildings, and change to the Safety Basis constitute a modification to the CWC facility as opposed to a new start up or restart

\section{Core Requirement 11}

Functions, assignments, responsibilities, and reporting relationships are clearly defined, understood, and effectively implemented with line management responsible for control safety.

Are the following prerequisites approved, in place, and ready for review?

1) Organization Chart with clear lines of command

The prerequisites for Core Requirement 11 appear to have been met and are ready for ORR commencement.

\section{Signatures:}

Group Leader / Team Member(s):

\section{Core Requirement 12}

The implementation status for DOE Order 5480.19, conduct of operations requirements for $\mathrm{DOE}$ facilities, is adequate for operations.

Are the following prerequisites approved, in place, and ready for review?

1) Conduct of Operations policy/procedure

The prerequisites for Core Requirement 12 appear to have been met and are ready for $\mathrm{ORR}$ commencement.

\section{Signatures:}

Group Leader / Team Member(s):

\section{Core Requirement 13}

There are sufficient numbers of qualified personnel to support safe operations.

Are the following prerequisites approved, in place, and ready for review?

\section{1) Staffing Plan.}

The prerequisites for Core Requirement 13 appear to have been met and are ready for ORR commencement.

\section{Signatures :}


Group Leader / Team Member(s):

\section{Core Requirement 14}

A program is established to promote a site-wide culture in which personnel exhibit awareness of public and worker safety, health, and environmental protection requirements and, through their actions, demonstrate a high priority commitment to comply with these requirements.

[This core requirement is not unique to the Phase $V$ Storage buildings or the change to the Safety Analysis Report and the ISB. The core requirement will not be reviewed.]

\section{Core Requirement 15}

The facility systems and procedures, as affected by facility modifications, are consistent with the description of the facility, procedures, and accident analysis included in the safety basis.

Are the following prerequisites approved, in place, and ready for review?

1) CWC ISB Compliance matrix

2) USQ evaluations relative to implementation of the Phase $V$ Storage Buildings.

3) Completed construction checklist for Phase V Storage.

There are no Prerequisite Checklists for Core Requirements 10, 14, 16, 17, 18 , and 20 , as they have been determined unnecessary per the DOE-RL approved Plan of Action.

\section{Core Requirement 19}

The technical and management qualifications of contractor personne], responsible for facility operations, are adequate.

Is the following prerequisite approved, in place, and ready for review?

1) Training and qualification records includes 2404 series buildings and associated revised ISB limits.

The prerequisites for Core Requirement 19 appear to have been met and are ready for ORR commencement.

Signatures:

Group Leader / Team Member(s): 


\section{APPENDIX B: CRITERIA AND REVIEW APPROACHES}

A11 Criteria and Review Approaches are to be conducted within the defined Scope. All references to "the facility" apply to CWC's Phase V Storage facilities only. All references to the "authorization basis" apply to the CWC Interim Safety Basis.

PHASE V STORAGE ORR IMPLEMENTATION PLAN HNF-SD-WM-IP-011, Rev. 0 Page BI 


\section{Core Requirement 1}

There are adequate and correct procedures and safety limits for operating the process systems and utility systems.

\section{Interpretation:}

Procedures include Facility 0perating (process and utility), Alarm Response, and administrative procedures. This core Requirement requires a review of the procedure changes made as a result of the Phase $V$ Storage being added to the CWC. Authorization basis documents include Technical Safety Requirements (TSRs) Administrative Controls (AC) and Criticality Prevention Specifications (CPS). The review will verify changes to these documents have been implemented in facility procedures. Authorization basis documents are to be assessed under Core Requirement 4. Acceptance Test Procedures (ATPs), Operational Test Procedures (OTPS), and Surveillance procedures are to be addressed under Core Requirement 5. Facility initial startup procedures are to be assessed under Core Requirement 10.

\section{Criteria:}

1. There is an adequate number of up-to-date procedures in place which support the operating status of the facility.

2. Operating procedures adequately and correctly incorporate the identified ACS, TSRs, and CPSs for operating process and utility systems.

3. Procedures provide operability and availability requirements for all systems and equipment.

4. Technical details are correct and consistent between procedures, drawings, system descriptions, training, etc.

5. Operating, Alarm response, and emergency operating procedures are adequately 7 inked and consider the emergency plan.

6. Operating procedures reflect the current configuration of systems.

7. Procedures, as applicable, address normal and off-normal events.

8. All safety basis requirements set forth in the ISB have been implemented into operating procedures as appropriate.

9. Procedures adequately describe all alarm conditions and response actions.

10. A program is in $\mathrm{place}$ that ensures the periodic review, revision, and approval of procedures.

11. A program is in place that provides a visible means to ensure evaluation and approval of temporary changes, by management and/or engineering, and timely removal when the purpose is superseded.

12. Controls are established and implemented that ensure only current and accurate procedures are available for distribution and use by plant personnel, including their use in training programs. 
13. As part of the process for maintaining procedures current and accurate, time is provided for training before significant procedure changes are put into effect.

14. A process is in $p l a c e$ which requires users of procedures to inform procedure writers of errors in procedures or difficulty in using procedures, and suggestions for improving procedure content or format.

15. A program is in $\mathrm{place}$ to ensure that regulatory-type commitments are reflected in procedures and remain in effect.

16. The Plant is properly labeled and labels/procedures match.

17. A11 procedures and procedure changes are written in accordance with the approved writers guide.

18. Procedures are verified and validated prior to use.

19. Procedures are clear, concise, and contain adequate information for users to understand and perform their activities effectively.

\section{Approach:}

1. Review the Plant Operating Procedures. Assure that the procedures were prepared in accordance with the Writers Guide and incorporate the ISB Technical Safety Requirements, Administrative Controls, and the Critical Safety Evaluation Report requirements.

2. Ensure procedures depict current faci]ity/equipment configuration including all labeling, and envelope operation of all required systems and anticipated plant processing configurations.

3. Review procedures to assure operating modes, include emergency conditions and recovery from process upset. Assure alarm response guidance and equipment/component labeling provides for appropriate personnel response and system recovery.

4. Observe operations for startup, operation, and shutdown. (This should be conducted with the process testing of Core Requirements 5 and 10 , or the on-the-job training (OJT) and/or performance demonstrations of core Requirements 2 and 3. )

5. Confirm that the requirements of Solid Waste Disposal Operations Administration (WHC-CM-5-34) and P1ant Operating Procedures Writers Guide (WHC-IP-0673 Rev. 1) are implemented for procedure review, revision, approval, temporary changes, currency, validation and walk down prior to use.

6. Review current Solid Waste Management Operations Manual procedures to assure they reflect Phase $V$.

7. Verify the facility has properly implemented SRIDS requirements for procedures.

Basis: 
It is essential that procedures are clear, concise, and valid to assure successful process operations and worker safety. If operations are based on incorrect system and equipment configuration, safety cannot be ensured. To ensure the safety envelope is maintained for this Hazard Category 2 facility, procedures must implement correct ACs and CPSs during normal and off-normal events. To assess the adequacy of operating procedures, the RT must determine if the Phase V Storage facilities' operating procedures properly control the plant configuration and meet the requirements of the ISB, TSRs, and CSER.

\section{References:}

1. WHC-CM-5-34, Solid Waste Disposal Operations Administration: Section 3.22, Operations Procedures Section 3.16, Al arm Management

2. CWC Interim Safety Basis

3. WHC-IP-0673, Solid Waste Disposal P1ant Operating Procedure Writers Guide 4. IOCFR820.120

5. WHC-IP-1120, Rev 4, Standards/Requirements Identification Document (SRIDS) 


\section{Core Requirement 2}

Training and qualification programs for operations and operations support personnel have been established, documented, and implemented (the training and qualification program encompasses the range of duties and activities required to be performed).

\section{Interpretation:}

The Core Requirement appijes to facility-specific qualification programs established for operations and direct support personnel (Facility Emergency Response Personnel, Engineering Personnel, Environmental Compliance, Fire Protection, Maintenance, Quality Assurance, Health Physics, Training, Industrial Hygiene, Industrial Safety, Nuclear Safety, Laboratory Support, Security, Records Management/Configuration Control, and 0ccurrence Reporting).

Adequacy of exams, exam results, and personnel level of knowledge are to be assessed under Core Requirement 3 . Adequacy of staffing levels is to be assessed under Core Requirement 13. Adequacy of management training and qualification is to be assessed under Core Requirement 19. Training requirements of non-facility emergency response personnel (e.g., fire department, ambulance, hazmat team, etc.) will be assessed under core Requirement 8.

\section{Criteria:}

1. Procedures are developed and implemented that describe the quatification process.

2. Procedures include examination requirements for certification of operations and maintenance personnel, requalification, maintenance of proficiency, granting of exceptions and extensions, alternatives to educational requirements, remediation, and evaluations by facility and training management.

3. Goals, objectives, and $p$ lans are in $p l a c e$ to describe the implementation of the training and qualification programs.

4. Classroom training is conducted in accordance with formal lesson plans based to established learning objectives.

5. Written and oral examinations are used to evaluate trainee comprehension of training content.

6. Training programs incorporate formal on-the-job training (0JT) and handson evaluation of skills.

7. The qualification program includes requirements for successful completion of written, oral, operations evaluations for operations and maintenance personne]. 
8. Procedures are in place to ensure that non-resident personnel have received the proper training for escorted and unescorted access to the CWC and are current in their training requirements.

9. The tasks required for the personnel working in the CWC are identified and documented through a systematic analysis of job requirements.

10. The training program is based on the results of this analysis. Learning objectives are derived from the analysis.

11. Requirements for continuing training have been adequately defined and programs have been developed.

12. Continuing training includes conduct of realistic drills to maintain proficiency in responding to abnormal and accident situations, including those involving radiological and dangerous waste hazards.

13. Training programs for operations and maintenance personnel include training on the requirements contained in the approved operating basis for the facility.

14. Training programs for operations and maintenance personnel emphasize the importance of compliance with procedures and safety requirements.

15. Training for technical staff personnel is based on an assessment of position duties and responsibilities associated with operating the CWC.

16. The training department uses post-training feedback, internal evaluations (self assessment), and operating experience to modify the training program when needed. This includes:

- Using feedback on training effectiveness from trainees and supervisors

- Incorporating feedback from operating experience at the site and from other DOE sites

- Conducting formal reviews of training effectiveness

- Incorporating comments from line management self-assessments and other audits.

\section{Approaches:}

1. Review training and qualification records for operators, maintenance personnel, shift technical engineers, and supervisors, including results of written, oral, and operational evaluations, to ensure the training program is being formally administered.

2. Verify training records are maintained in an auditable manner and support management information needs by providing required data on each individual's training participation, performance, and qualification or certification. 
3. Review the evaluation and self-assessment program for involvement by facility and training management in program, instructor (classroom and OJT), and training materials assessment.

4. Review the remedial training program for adequacy.

5. Review the CWC access control procedures for positive control of nonresident personnel.

6. Review the written goals and objectives related to the implementation of the training and qualification processes and ensure they are documented in strategic plans and that the goals and objectives adequately address the current issues that are important to both contractor management and DOE.

7. Review operations and maintenance lesson plans for incorporation of safety requirements, technical safety requirements, operational safety requirements, and procedure compliance.

8. Review trainee feedback forms, training evaluations of lessons learned from operating experiences, and formal training program reviews to verify feedback is addressed in a formal manner.

9. Review the continuing training program plan and drill schedule to verify its adequacy to support safe operations.

10. Review the systematic analysis of job requirements conducted to provide reasonable assurance that all tasks essential to safe and efficient operation of the CWC are addressed by the training program.

11. Verify that subject matter experts, line management, and training staff developed and maintain a valid CWC operations task 1ist as the basis for the training program.

12. Verify that the current facility safety analysis report, operating procedures, technical and professional references, and facility/industry operating experience are used to jentify training content and information for use in developing training materials.

13. Review the degree to which on-the-job training and hands-on evaluations for operations and maintenance personnel are used to reinforce classroom activities.

14. Interview training personnel to determine if they have sufficient experience and qualifications for assessing operations and maintenance personne1.

15. Interview training personnel responsible for training, and drill scenario development and implementation.

16. Interview personnel responsible for establishing training needs for operations and maintenance personnel.

17. Observe operator, operations support personne1, or supervisor examinations, by attending oral or operational evaluations (OJT), if possible. 
18. Verify that personnel demonstrate knowledge of activities and evolutions that were included in their training program.

19. Observe operator and maintenance personnel response to drills.

20. Evaluate a training classroom lecture or field training activity for technical and administrative adequacy.

\section{Basis:}

State and Federal laws and regulations require specific training programs to be developed and implemented. This review wi1l ensure that Federal and State requirements, as we17 as best management practices, are implemented.

\section{References:}

1. WHC-CM-5-34, Solid Waste Disposal Operations Administration Section 1.8, Training Administration Section 3.10, On-the-Job Training

2. WHC-IP-0867, Operation Training Materials Development Guidelines

3. WHC-IP-1120, Rev 4, Standards/Requirements Identification Document (SRIDS) 


\section{Core Requirement 3}

Level of knowledge of operations and operations support personnel is adequate based on reviews of examinations and examination results and selected interviews of operating and operations support personnel.

\section{Interpretation:}

This Core Requirement is to ensure operations and direct support personnel (Facility Emergency Response Personnel, Engineering Personne1, Environmental Compliance, Fire Protection, Maintenance, Qualjty Assurance, Health Physics, Training, Industrial Hygiene, Industrial Safety, Nuclear Safety, Laboratory Support, Security, Records Management/Configuration Control, and Occurrence Reporting) are technically competent in all aspects of their assigned duties.

The adequacy of management personnel is to be assessed under core Requirement 19. Training requirements of emergency response personnel outside of the facility (e.g., fire department, ambulance, hazmat team, etc.) will be assessed under core Requirement 8.

\section{Criteria:}

1. The level of Phase $V$ Storage operations and direct support personnel's knowledge, skill, and abilities are adequate to operate in compliance with the CWC operating and administrative procedures, as evidenced by selective interviews of personne1, review of examinations and examination results by the RT.

2. Examinations given to personnel are adequate in their depth and breadth of subject matter as it pertains to the operation under review and the assigned duties of personnel.

3. On the job observations of selected operations and operations support personnel convey the impression that personnel are competent and able to operate the storage facilities in accordance with all applicable procedures.

4. Exams are based on current, technically descriptive documents such as procedures, ISB, vendor information, facility drawings, and hazard analysis.

\section{Approach :}

1. Review and assess test material to verify it adequately reflects training content. Verify pass/fail criteria for test material is clearly defined, with results utilized in determining personnel qualifications.

2. Review and assess test material to verify it adequately tests for an understanding of system capabilities, limitations, and procedures.

3. Conduct interviews with operations personnel to verify they have an adequate understanding of technical fundamentals, procedures, procedure compliance, allowed emergency actions, ACs, and CPSs. 
4. Observe operations during Core Requirements 5 and 10 to evaluate the effectiveness of training.

5. Ensure facility personnel are trained on current fire and emergency information and are knowledgeable of their responsibilities during emergency conditions.

6. Interview personnel to determine their knowledge of information regarding Basis: the various types of facility hazards and stop work authority.

The Defense Nuclear Facilities Safety Board (DNFSB) Recommendations 90-4, 91$3,91-4,92-3$, and 92-6 delineated the important facets of a readiness review. These included assessment of the level of knowledge achieved during operator qualification programs as evidenced by review of exam questions and results and by selective observations of plant operations and by interviews of operators by the readiness review group.

\section{References:}

1. WHC-CM-5-34, Solid Waste Disposal Operations Administration Section 1.8, Training Administration Section 3.10, On-the-Job Training

2. WHC-IP-0867, Operation Training Materials Development Guidelines

3. WHC-IP-1120, Rev 4, Standards/Requirements Identification Document (SRIDS)

\section{Core Requirement 4}

Facility safety documentation is in place that describes the "safety envelope" of the facility. The safety documentation should characterize the hazards/risks associated with the facility and should identify mitigating measures (systems, procedures, administrative controls, etc.) that protect workers and the pub1ic from those hazards/risks. Safety systems and systems essential to worker and public safety are defined and a system to maintain control over the design and modification of facilities and safety-related utility systems is established.

\section{Interpretation:}

This Core Requirement requires a review of all safety documentation. Configuration management is assessed under Core Requirement 8.

\section{Criteria:}

1. The authorization basis for operation has been established, reviewed, and approved.

2. Systems and support systems to be operated within authorization basis.

3. Documentation provides for the protection of the worker and the public.

4. Documentation is in accordance with applicable administrative and regulatory requirements for this type of facility.

5. A program is in $\mathrm{place}$ that identifies workplace hazards and the information is used in planning and conducting facility work. 
6. A program is in $\mathrm{place}$ to update the ISB and to evaluate impact of changes or errors to the authorization basis.

\section{Approach:}

1. Ascertain that the authorization basis has been reviewed and approved by the proper organization based on the approval designator.

2. Review operating, maintenance, and administrative procedures to determine if the operation described is in within the limits of the authorization basis and proper controls are provided to maintain those limits.

3. Review selected procedures to ascertain that the requirements of the authorization basis are noted as appropriate.

4. Review documentation to ascertain that requirement for worker safety as it relates to industrial, hygiene, radiological safety, has been established.

5. Review the configuration control program to determine if changes include an evaluation for worker safety and authorization basis impact.

6. Verify a program is in place that identifies workplace hazards and the information is used both in planning the work tasks and used by operating personnel in conducting work.

Basis:

Expert judgment, applicable DOE Orders and industrial standards are the primary basis for the above criteria and approach.

\section{References:}

1. WHC-CM-5-34, Solid Waste Disposal Operations Administration Section 1.3, Fire Protection Program

Section 1.14, ALARA Program

Section 1.15, Safety Analys is

Section 2.1,7 Criticality Safety

2. WHC-IP-1120, Rev 4, Standards/Requirements Identification Document (SRIDS)

\section{Core Requirement 5}

A program is in place to confirm and periodically reconfirm the condition and operability of safety systems, including safety related process systems and safety related utility systems. This includes examinations of records of tests and calibration of safety system and other instruments which monitor limiting conditions of operation or that satisfy technical safety requirements. All systems are currently operable and in a satisfactory condition.

\section{Interpretation:}

This Core Requirement applies to Acceptance Testing, Operational Testing, safety related system operability and condition tests, and Surveillance 
program. The Maintenance Program and Calibration Program will be assessed under Core Requirement 8.

\section{Criteria:}

1. An adequate survejllance program is in place. Adequate documentation to support the implementation of this program is maintained.

2. An adequate test program is in place. Adequate documentation to support the implementation of this program is maintained.

3. All safety systems and safety related process and utility systems are operable and available.

4. Acceptance Test Procedures have been completed and documented for all facility systems.

5. Operational Test Procedures have been completed and documented for all facility systems.

6. The configuration management, maintenance, operation, environmental compliance, and radiological programs document program requirements and organizational responsibilities for testing, inspecting, surveilling, performing corrective and preventive maintenance, modifying and postmaintenance testing of systems for the Phase $V$ Storage area.

7. Review of completed surveillances and/or tests are conducted to ensure that acceptance criteria are met and any trends are identified.

8. ATPS and OTPs contain acceptance requirements delineating the minimum standards acceptable for components and/or systems as appropriate.

9. Administrative controls are established to maintain test records.

\section{Approach:}

1. Review the implementing procedures to assure that the worker safety aspects are addressed and that the responsible technical support staff for the procedures are knowledgeable of the requirements.

2. Review surveillance procedures to assess if the appropriate amount of rigor is being applied for this type of facility.

3. Review ATPS and OTPS to verify the adequacy of the administrative contro] program for test record retention and retrieval process, documentation for completion of testing and operational turnover. Verify that all tests were reviewed and approved by appropriate organization and departments.

4. Interview configuration management, maintenance, operation, environmental compliance, and radiological controls personnel to verify an adequate understanding of test, inspection, surveillance, corrective and preventive maintenance, modification and post-maintenance testing responsibilities, including a working knowledge of the various organizational interfaces and flow of information/data. 
5. Verify ATPs and OTPs have acceptance criteria defined, and the testing verified that they were met.

6. Ensure authorities are identified that can approve changes. Confirm that the configuration management control processes include the development of operational history documentation that can be used to help provide guidance to assure mission success.

7. Review operability of: Critical systems; Compressed Air System; Fire Suppression System; Radiation Detection and Control Devices.

\section{Basis:}

A11 elements of the operating program, including procedures and training, should be adequate to assure continued systems operability and to keep design limits visible to plant personnel and assist in fostering an effective safety culture. It is important to verify that proper operability acceptance criteria were used in turnover tests and that these criteria are effectively documented. Standard industry practice requires proper documentation of acceptance criteria in procedures, and verification that operating limiting conditions meet all functional design requirements.

\section{References:}

1. WHC-CM-5-36, Solid Waste Disposal Internal Requirements Section SWD-4-2, Qual ity Assurance

Section SWD-6-1, Standard Engineering Practices

Section SWD-6-2, Project Management

2. WHC-IP-1120, Rev 4, Standards/Requirements Identification Document (SRIDS)

3. WHC-CM-5-34, Solid Waste Disposal Operations Administration

Section 1.9, Quality Assurance Program

Section 1.13, Processing and Transferring Records

Section 3.13, Control of Equipment

4. WHC-IP-1026, Engineering Practice Guidelines 


\section{Core Requirement 6}

A process has been established to identify, evaluate, and resolve deficiencies and recommendations made by oversight groups, official review teams, audit organizations, and the operating contractor.

\section{Interpretation:}

This Core Requirement is not unique to the Phase $V$ Storage buildings or to the change to the CWC Authorization Basis by the implementation of the ISB. However, since the entire program for CWC was recently reviewed by the Facility Evaluation Board (FEB), the facility is in the middle of the corrective action plan for the findings during that review. The scope of the review for this ORR will be limited to the status and implementation of Corrective Action Plan developed as a result of the FEB assessment.

\section{Criteria:}

1) A system for identifying, reviewing, cataloging, and resolving deficiencies and recommendations is adequately implemented. $\quad(5480.19, \mathrm{CH}$ VI and VIII; 5700.6C, para 9.b(1)(c), 9.b.(3)(a)).

\section{Approach:}

1) Review the Corrective Action Plan developed as a result of the FEB assessment of December 1996, at CWC.

2) Verify implementation of the Corrective Action Plan to date has effectively addressed and rectified nonconformances identified in the FEB Assessment. 


\section{Core Requirement 7}

A systematic review of the facility's conformance to applicable DOE orders has been performed, any nonconformances have been identified, and schedules for gaining compliance have been justified in writing and formally approved.

\section{Interpretation:}

This Core Requirement is to review and assess the facility's performance of a compliance review against RFSH contractual requirements.

Actual verification of compliance with RFSH contractual requirements is performed under all other Core Requirements.

\section{Criteria:}

1. A compliance assessment has been completed, non compliances have been identified, and schedules for gaining compliance have been made.

\section{Approach:}

1. Review and assess documentation of the facility's compliance assessment.

2. Review and assess corrective action schedules.

3. Review and assess efforts to meet corrective action schedules.

\section{Basis:}

The Core Requirement stems from a DNFSB recommendation which requires DOE nuclear facilities to identify the specific standards and requirements considered applicable to the design, construction, operation, and decommissioning of the facility. The recommendation also requires conformance to identified standards and requirements.

\section{References:}

1. DNFSB Recommendation 90-2, Requirements Information Document 


\section{Core Requirement 8}

Management programs are established, sufficient numbers of qualified personnel are provided, and adequate facilities and equipment are available to ensure operational support services (e.g., training, maintenance, waste management, environmental protection, industrial safety and hygiene, radiological protection and health physics, emergency preparedness, fire protection, quality assurance, criticality safety, and engineering) are adequate for operations.

\section{Interpretation:}

This Core Requirement requires review of support services management programs, personnel, facilities, and equipment, which were established and procured specifically for the facility being reviewed. As an example, a training office and managing staff established for the facility is within the scope of the review, but the rest of RFSH and FDH training department is not within the scope of the review. Staffing is assessed under Core Requirement 13.

This Core Requirement has been broken into 12 twelve separate sub Core Requirements and each one will be individually reviewed as outlined below. 
8.1.

There is an adequate emergency preparedness organization and program.

\section{Criteria:}

1. Emergency and off-normal procedures effectively guide personnel in responding to single and multiple events.

2. An approved emergency plan and supporting documents exist and have been tested to ensure effective emergency preparedness and response. Provisions are in place to upgrade the Emergency PTan based on lessons learned from dritls, exercises and actual emergencies. The emergency plan incorporates required emergency preparedness program features.

3. Facility Emergency Response personnel are trained to effectively respond and mitigate the consequences of emergencies (assessed under core

Requirements 2 and 3, provided here for information and completeness). Facility non-emergency response personnel are adequately trained on emergencies situations (assessed under Core Requirements 2 and 3 , provided here for information and completeness). Non-facjlity emergency response personnel are aware of the change in the CWC facility status.

4. Facilities, equipment, and resources are in place and adequate to support emergency response operations and ensure the protection of all personnel (e.g., Emergency operations Center, backup or alternative facilities, primary and backup communication, al arms adequate to notify personnel, transportation, medical treatment, respiratory equipment, exposure controls, instrumentation to measure exposure, etc.)

5. Provisions and procedures are in place to support correct classification of emergencies, assessment of consequences, notification of emergency response personnel, and to recommend appropriate protective actions.

6. Hazards assessments are prepared, documented, and maintained which considers emergency events that could affect Phase V Storage.

7. Individuals and alternates are designated to perform all emergency roles using clear lines of succession.

\section{Approach:}

1. Interview individuals responsible for implementation of the emergency preparedness program. Ensure that the emergency preparedness program includes the necessary elements of staffing, management support, resources, training, and planning, to cope with emergencies.

2. Review procedures (operations, maintenance, surveillance, RADCON, administrative, etc.) to verify that emergency and off-normal event are sufficiently linked to the emergency plan. Through discussions with operations personnel and facility managers, confirm knowledge of emergency/off-normal operating procedures. During conduct of the ORR, evaluate how personnel utilize procedures during event drills. 
3. Review the Emergency $\mathrm{Pl}$ an and supporting documentation and compare to the requirements of the ISB, Health and Safety Plan (HASP), Hazards Baseline Assessment, TSR, and CSER. Ensure that provisions are in $\mathrm{place}$ to incorporate drills and actual emergency lessons learned into the Emergency Plan.

4. Review procedures and training material for non-facility emergency response personnel (e.g., fire department, ambul ance, hazmat team, security, etc.) to assure Phase V Storage has been included.

5. Review the Emergency Plan for commitment and definition of facility, equipment, and resources for emergency response. Conduct a site walk through to ensure medical, fire, hazmat, radiological response, and monitoring equipment are in $\mathrm{p} 7$ ace. Review surveillance procedures for emergency response equipment to ensure their continued maintenance and ensure up-to-date contact names and telephone numbers are provided at al1 times.

6. Interview personnel responsible for classification of emergencies to determine if the classification scheme is consistent with operating procedures and technical specifications.

7. Perform walk down of facilities and equipment, review procedures and interview appropriate onsite and, as necessary, offsite personnel to verify that provisions are adequate and in place for transportation and treatment of contaminated/injured personne1, fire/rescue support, and protection of security personnel during emergencies.

8. Review Hazard Analysis to ensure a comprehensive hazard assessment has been conducted and that the emergency $\mathrm{p}$ lan is responsive to the full spectrum of accidents.

9. Review procedures (operations, maintenance, surveillance, RADCON, administrative, etc.) to verify that emergency and off-normal event are sufficiently linked to the emergency $\mathrm{plan}$. Through discussions with operators and operations managers, confirm operator knowledge of emergency/off-normal operating procedures. During conduct of the ORR evaluate how personnel utilize procedures during event drills.

10. Ensure up-to-date contact names and telephone numbers are provided at all times.

Basis:

An effective emergency preparedness, and response program is necessary to help ensure the safety and health of workers, public, property and environment in the event of an emergency. Emergency management programs should be in $\mathrm{place}$ to enable organizations to respond to an emergency in a timely, efficient, and effective manner, resulting in mitigation of consequences and recovery. Hazard assessments are to be used as the basis of the emergency preparedness program.

\section{References:}

1. WHC-CM-5-36, Sol id Waste Disposal Internal Requirements Section 4-43 Emergency Management Resources

2. WHC-CM-5-34, Solid Waste Disposal Operations Administration 
Section 1.18, 0ccurrence Reporting and Processing

3. WHC-IP-1233, Rev 0, Solid Waste Disposal Micro S/RIDS

4. WHC-IP-1120, Rev 4 Standards/Requirements Identification Document (SRIDS)

5. ISB

6. HASP

7. Baseline Hazard Assessment

8. TSR and CSER

\section{2}

There is an adequate engineering support organization and program including the cognizant/system engineer approach.

\section{Criteria:}

1. The organizational structure is clearly defined and staffing and resources are sufficient to accomplish tasks assigned to the organizational elements. (Assessed under Core Requirement 11, provided here for information and completeness)

2. Adequate facility specific training, is provided to the engineers. (Assessed under Core Requirements 2 and 3 , provided here for information and completeness)

3. Responsibilities, authority, and interfaces for each organizational position are clearly defined and understood. (Assessed under Core Requirement 11, provided here for information and completeness)

4. Goals, objectives, and standards for performance of engineering support activities are adequately established, communicated, and reinforced. (Assessed under Core Requirement 11, provided here for information and completeness)

5. The effectiveness and level of expertise of engineering support are periodically and adequately assessed. (Assessed under core Requirement 13, provided here for information and completeness)

6. Actions and controls within engineering support demonstrate that configuration control is maintained and a configuration management system is in place that ensures drawings, procedures, safety equipment 1 ists, ISB, training materials, etc. are kept current. (Assessed under core Requirement 8.13, provided here for information and completeness)

7. Procedures and controls that ensure safe and reliable operations are adequately employed in the conduct of engineering activities.

8. Standard engineering practices, principles, convention, and approaches are employed.

\section{Approach:}

1. Obtain and review programs, processes, and procedures which control engineering work and confirm appropriate checks and balances exist which would preclude or correct errors (e.g., design, procedure, etc.), standard engineering practices and approaches are employed. 
2. Interview engineering support personnel to confirm their understanding of governing and applicable programs/procedures. Include confirming their knowledge of applying these programs and procedures.

3. Through discussions with maintenance, operations, and management, develop an understanding of the adequacy of engineering. Determine backiog of work and the time to complete. Determine if responsibility for completing work is clearly defined.

Basis:

It is industry practice to establish an engineering support organization which clearly defines its management authority, responsibility, and accountability and which serves to provide the technical expertise necessary to support the needs of operations, maintenance, and facility management personnel.

\section{References :}

1. WHC-IP-1120, Rev 4, Standards/Requirements Identification Document (SRIDS)

2. WHC-CM-5-36, Internal Requirements

Section 1-5, Standard Operating Practices

Section 4-2, Quality Assurance

Section 4-27, Radiological Control Practices and Procedures

Section 4-29, Nuclear Criticality Safety

Section 6-1, Standard Engineering Practices

Section 8-7, Operations Support Services

3. WHC-CM-5-34, Solid Waste Disposal Operations Administration

Section 1.9, Quality Assurance Program Plan

Section 1.14, ALARA Program

Section 1.24, Unreviewed Safety Questions

Section 2.1, Configuration Change Contro]

Section 2.2, Solid Waste and T Plant As-Built Drawing Control

Section 2.3, Technical Notebooks

Section 2.4, Configuration Management

Section 2.11, Job Control System

Section 2.17, Criticality Safety

Section 3.1, Material Control

4. WHC-IP-1026, Engineering Practices Guidelines 


\section{3}

There is an adequate environmental protection organization and program, to include Air Quality, Surface Water, Groundwater, Solid and Hazardous Waste, Hazardous Material Handling, Environmental Monitoring, Hazardous Substance Release Reporting, and Environmental Protection Quality Assurance.

\section{Criteria:}

1. Environmental Compliance programs are defined in formal policies, standards, and procedures.

2. A plan for monitoring air-effluent sources has been formalized in a document and has received appropriate review and approval.

3. There is a formal waste program that describes procedures, roles, and responsibilities for identifying, characterizing, and managing a11 waste streams.

4. There is a formal waste minimization program and plan.

5. There is a formal program that defines the use of chemicals and toxic materials. Inventory control procedures are in place for monitoring and limiting the type and quantity of chemicals and toxic materials purchased. Procedures are established and implemented to prevent the release of toxic chemical materials to the environment.

6. There are response action pians or equivalent documents that outline the nature and scope of the response action program and outline the specific responsibilities for, and procedures to assess, all releases potentially subject to reporting and notification requirements.

7. All required permits for construction and operations are possessed and associated requirements in effect (e.g., air, water, waste, TSD, etc.).

8. All environmental reviews and studies have ben performed (e.g., NEPA, etc.)

9. A system is in place and implemented to provide estimates of quantities and assess the integrated impact of releases of hazardous material on personnel, the public, and the environment.

10. Hazardous substances are monitored, sampled, and analyzed in order to support making notifications and reporting reportable quantities to authorities.

11. Environmental sampling programs are conducted to establish a base 7 ine for radioactivity in the environment in the vicinity of Phase $V$ Storage for use as a basis of comparison in the event of an excursion involving the plant.

12. Equipment and resources for sampling and analysis of environmental media are in $\mathrm{place}$ to provide assurance that significant releases from Phase $V$ Storage are not occurring and radioactive or hazardous materials are not 
accumulating in the environment. Verify the data can be analyzed in a timely manner.

13. Procedures are in place that describe how to operate the equipment used to sample and analyze.

14. Personnel in Environmental Compliance have the needed knowledge, skills, and abilities to conduct the program. (assessed under Core Requirements 2 and 3 , provided here for information and completeness)

15. Phase $V$ Storage impact has been assessed by independent monitoring groups and appropriate actions have been taken to accommodate.

16. Intra-building waste movements are made under a documented control system that provides for positive tracking of package movement, and movement approval.

\section{Approach:}

1. Verify that all procedure (normal and off-normal) that could impact the environment are reviewed by CWC Environmental Compliance.

2. Review documentation, interview staff, and make field observations to ensure the CWC Environmental Compliance program address all activities necessary to implement PHMC environmental policies.

3. Verify that Environmental Compliance procedures are technically correct, current, and have a level of detail appropriate for the activities to which they apply.

4. Review the air quality program to ensure that CWC has a plan for monitoring air-effluent sources which has been formalized in a document and has received appropriate review and approval.

5. Verify that Spi11 Prevention, Control, and Countermeasures (SPCC) plans are reviewed for applicability to Phase $V$. Plans must be reviewed and recertified at least every three years, but should be reviewed and amended at any time when substantive changes may occur. Verify SPCC and BMP plans contain specific spill reporting instructions as required by the applicable regulation.

6. Verify that spill plans which involve emergency responses and notification, that up-to-date contact names and telephone numbers are provided for the proposed startup date.

7. Review documentation, make field observations, and interview staff to verify that there is a formal, facility-wide waste program in place which describes procedures, roles and responsibilities for identifying, characterizing, and managing a1] Phase $V$ waste streams.

8. Review documentation, make field observations, and interview staff to verify that there is a formal waste minimization program and plan for Phase V. 
9. Review documentation, interview staff, and make fjeld observations to verify that inventory control procedures are in place for monitoring and limiting the type and quantity of toxic and chemical materials purchased, and that procedures are established and implemented to prevent the release of toxic and chemical materials to the environment.

10. Verify that procedures for operating monitoring, sampling and laboratory analyses equipment have been developed, reviewed, approved, and issued, to insure they are appropriate for the constituent(s) being monitored.

11. Review procedures and observe operations of equipment used for sampling, monitoring, and analyzing hazardous substances to verify that the facility has the ability to determine if releases are occurring, can collect data for notification and reporting as directed by Federal and state requirements and can characterize waste.

12. Verify that the pre-operational baseline assessment of environmental radioactivity levels has been reviewed to ensure that measurable changes in radioactive levels, which are significant per regulatory basis, can be determined.

13. Verify that all Phase $V$ environmental permits and studies are complete; and no additional permits or studies are required. Verify that all identified permit requirements and actions have been completed or are captured within the CWC compliance program.

14. Coordinate verification of criterion 14 with reviews conducted on Core Requirements 2 and 3.

15. Verify that corrective actions identified by the Facility Evaluation Board have been closed, or suitably dispositioned.

16. Verify administrative controls for intra-building waste movements are issued and applicable to Phase $V$ implementation.

Basis:

Various sections of 40CFR, 49CFR, WAC 173, WAC 197, and WAC 246 require the preparation of an environmental management program which should include all procedures necessary to establish and implement an effective environmental program.

Regulations promulgated under the Resource Conservation and Recovery Act require solid, hazardous, and mixed waste be characterized and managed in a manner to ensure safe accumulation, storage, treatment, and/or disposal of such wastes.

DOE Order 5500. 2B, Emergency Categories, Classes, and Notification and Reporting Requirements, requires immediate notification of DOE Headquarters Emergency Operations Center and the National Response Center as soon as, possible (within 24 hours) after discovery of a hazardous material spill or release to the environment (in excess of reportable quantities) as a result of DOE operations. 


\section{References:}

1. WHC-IP-1120, Rev 4, Standards/Requirements Identification Document (SRIDS)

2. WHC-CM-5-36, Sol id Waste Disposal Internal Requirements Section 2-14, Hazardous Material Packaging and Shipping

Section 4-2, Quality Assurance

Section 5-16, Solid Waste Management

Section 7-5, Environmental Compliance

3. WHC-CM-5-34, Solid Waste Disposal Operations Administration Section 1.9, Quality Assurance Program Plan

Section 1.12, Hazard Communication Program

Section 1.16, Hazardous Material Packaging and Transportation

Section 1.28, Waste Generation and Control

Section 3.3, EPCRA 312 Chemical Inventory Release Reporting

Section 3.4, Chemical Release Reporting 


\section{4}

There is an adequate fire protection program.

\section{Criteria:}

1. The Hanford Fire Department is cognizant of CWC's needs and have taken appropriate actions to meet.

2. Administrative procedures are established to control specific fire hazards.

3. All facility fire hazards are identified and evaluated on a continuing basis. A Fire Hazard Analys is is documented and complete.

4. Requirements of NFPA and Life Safety Code are specified, implemented, and maintained.

5. Fire protection systems and equipment are available as specified in fire protection program documents.

6. A pre-fire plan is in place and it reflects the current conditions in the facility.

7. A qualified cognizant individual is identified as the single point of contact for CWC's fire systems and fire protection program.

8. Procedures/policies provide for appropriate notifications of fire protection system outages.

9. Provisions are made for the proper storage of radioactive, flammable, and combustible materials.

10. Fire emergency procedures are established and implemented.

11. Means of controlling liquid run-offs from a credible fire are provided so that contaminated (including non-radiological containments) liquids, including potentially contaminated water resulting from fire fighting operations, will not escape to the environment.

\section{Approach:}

1. Identify and review procedures related to fire protection. Verify that procedures are in place for combustible and flammable materials, hot work including cutting and welding, smoking, and fire protection system impairments. Inspect existing conditions to determine implementation of the identified procedures.

2. Review the Fire Hazards Analysis to determine that al7 facility areas and fire hazards are included. Determine that operating parameters were considered, including unusual operations, ventilation requirements, maintenance activities, and radiation control parameters.

3. Review the fire protection program and assure the requirements for periodic review are identified. Review work control procedures to confirm 
the requirement for independent safety review (fire protection) in the modification approval cycle. Interview engineering and Safety personnel to determine the level of understanding of the review process.

4. Verify that construction has implemented the Fire Protection requirements identified in Construction specifications through design and installation.

5. Inspect the facility to observe existing conditions for compliance to fire protection requirements, such as; 1) Proper portable fire extinguishers are mounted, marked and operable, 2) Activities site access is clear and unobstructed for emergency vehicle response, 3) Fire hydrants are accessible, 4) Exits are arranged and maintained to provide free unobstructed egress from the facility, 5) Exit routes are clearly marked and 117 uminated where required, 6) Emergency lighting is provided and operable where required, 7) Proper storage of radioactive, flammable and combustible material.

6. Interview the Fire Department to ensure they are cognizant of CWC's (in general) and Phase $V$ Storage (in particular) needs and have taken ali appropriate actions.

7. Ensure a Pre-Fire Plan is in place which adequately encompasses the facility.

\section{Basis:}

The fire protection program must be initiated by management to function effectively across all lines of facility operations. The fire protection program must address the specific hazards and incorporate the concept of "defense in depth." Fire protection systems must be designed to accomplish defined objectives.

\section{References:}

1. WHC-IP-1120, Rev 4, Standards / Requirements Identification Document (SRIDS)

2. WHC-CM-5-34, Solid Waste Disposal Operations Administration Section 1.3, Fire Protection Program 


\section{5}

There is an adequate maintenance organization, program and work control system.

\section{Criteria:}

1. The Maintenance Program adequately defines organizational responsibilities for the maintenance process. The Maintenance Program adequately defines maintenance program elements including corrective maintenance, preventive maintenance, preventive maintenance schedules, instrument and calibration, temporary repairs, predictive maintenance, and maintenance of test equipment.

2. Technical support from engineering and other functional specialties is available and adequately specified to ensure: a) configuration management requirements are met, b) health and safety of the work force and protection of the environment are maintained during maintenance activities, and c) engineering performs failure analysis on significant equipment failures. The analysis should include a review of similar failures and design reviews as appropriate.

3. An adequate formal work control process provides:

a. Equipment deficiency identification, prioritization, corrective action tracking, and equipment history.

b. Formal work authorization, job planning, scheduling, and backlog measures.

c. Work controlled by written procedures using qualified personnel.

d. Post-Maintenance Testing (PMT) to assure equipment operability. Reworked, repaired, and replacement items are inspected and tested in accordance with the original inspection and test requirements or acceptable alternatives.

e. Clear definition of responsibilities for initiating work requests, approving completed work, and for ensuring that work is completed as scheduled, are in place.

4. Management has established standards for what is an acceptable amount of maintenance backlog and a system exists to control and review the open work backlog.

5. The maintenance backlog, for systems important to safe operation, is adequately managed and includes an effective review for safety implications and justification for continued operations.

6. Means are provided to ascertain the availability and operability of systems important to safe operations. Means are provided to ascertain any overdue preventive maintenance or calibration for these components.

7. Adequate staffing and resources are provided to assure quality work and work backlogs consistent with maintaining acceptable physical condition 
(assessed under Core Requirement 13, provided here for information and completeness).

8. An effective procurement and material control process provides parts, spare parts, materials, equipment, supplies, tools, and services for work activities.

9. Responsibilities have been assigned for identifying, sourcing, processing, testing and inventory management of parts, spare parts, materials, equipment, supplies, tools, and services.

10. Traceable characteristics for parts, spare parts, materials, equipment, supplies, and tools (e.g., stock on hand, reorder mechanism, substitutability, detail specifications, shelf 1 ife, etc.) have been estab] ished and documented and are accessible to users in a timely fashion.

11. The supply of parts, spare parts, materials, equipment, supplies, tools, and services are adequate to support the facility and compatible with staffing levels.

12. Maintenance test equipment, tools, and supplies are compatible with the environmental conditions expected for normat and off-normal operations.

13. An adequate calibration and repair program is in place. Adequate documentation (e.g., calibration procedures) to support the implementation of this program is maintained.

14. Measurement and test equipment calibrations are traceable to national standards. The equipment control process has been validated, and adequate recall requirements have been specified to maintain calibration limits.

15. Instrument/equipment calibrations are maintained on schedule and documented as required by applicable procedures. All required instruments/equipment are calibrated.

16. Instruments/equipment are labeled or tagged or otherwise controlled to indicate due date of next calibration.

17. Instrument/equipment is calibrated at specified intervals based on the required accuracy, purpose, degree of usage, stability characteristics, and other conditions affecting the measurement.

18. Testing frequencies are based on approved TSRs.

19. Instrument "set-points" are maintained, traceable, and documented in a controlled manner, and ongoing testing requires documentation of "as found"/"as left" conditions.

20. Equipment maintenance history is maintained and used in maintenance planning.

21. A process is in place to collect information relevant to improved maintenance practices from vendor bulletins and other operating 
experience, and to integrate this feedback into the maintenance programs.

22. An adequate maintenance performance assessment program has been implemented.

23. A process is in place that monitors maintenance rework, evaluates the cause of the rework, and determines what corrective measures are necessary to minimize the amount of rework.

24. Maintenance, work control, and material control personnel have the necessary knowledge, skills and abilities to adequately manage the respective programs. (assessed under Core Requirements 2 and 3 , provided here for information and completeness).

25. Maintenance facilities, equipment, and tools are maintained in good condition.

26. Maintenance work areas are maintained in a clean and orderly fashion.

27. Contaminated tools will be segregated from clean tools. Reuse is stressed and supported by storage and tool control system.

28. Provisions are made for proper storage, segregation, and control of hazardous materials such as chemicals, reagents, explosives, and flammables.

29. Maintenance facility size, location, and arrangement promote safe and effective completion of work.

30. Suitable storage is provided for tools, supplies, jigs, and fixtures.

31. Suitable facilities are available to decontaminate tools and equipment.

32. Laydown areas are identified and controlled.

\section{Approach:}

1. Review technical manuals, maintenance procedures, operating procedures, etc. to identify parts, spare parts, materials, equipment, supplies, and tools.

2. Review the process/program used for determining/controlling parts, spare parts, materials, equipment, supplies, tools, material requirements, records control, procurement specifications, materials availability, storage locations, and special criteria for preventive maintenance or shelf-life.

3. Select a few critical parts, materials, supplies, and tools and review the procurement process to verify that appropriate specifications and use requirements were included.

4. Review the program for controlled storage and inventory management of critical equipment and consumables. Assure that required traceability is 
identified consistent with the use of the item. Interview personnel working in maintenance, engineering, and work control to verify their knowledge of component storage and inventory management. If a computerized data base is available, select random line items and assess data completeness and integrity.

5. Conduct interviews with maintenance, operational, work control and engineering personnel to verify their knowledge of the work control process from identification of needed maintenance/modification through package preparation to field work completion. Review the prioritization process including utilization of schedules.

6. Review maintenance procedures and management policies to assure they include the requirements of the ISB, CSER, and mission objectives for the facility, processes/systems, and equipment operation. Assure they include guidance for identifying equipment deficiencies and controlling the prioritization, planning, scheduling, and authorization of work.

7. Review the project turnover remaining punchlist items and corrective maintenance items identified during OTPs and to determine appropriate inclusion into the work backlog list. Determine if the appropriate priority for corrective action was included and if responsible management are aware of the commitment.

8. Review management standards and goals related to maintenance backlog management to assure facility safety performance and process thruput commitments are included. Conduct an assessment of backlog reasonability in terms of aging, preventive/corrective maintenance mix, reasons for delay and potential implications for safe operations.

9. Verify that methods exist for prompt identification to operational personnel of inoperable equipment with appropriate incorporation into the maintenance program. Review process and procedures governing the "daily schedule" communication vehicle to ensure that appropriate management and support personnel are apprised of operations and maintenance problems affecting systems important to safe operations. Ensure that overdue preventive maintenance and calibrations are considered and included in equipment availability reporting.

10. Ensure a system is in place to inform operations of any unscheduled/ emergency/accident situation "on or off facility" that may cause safety systems or safety related utilities to be completely or partially inoperative for any length of time.

11. Review maintenance packages to determine the adequacy of post maintenance testing. Ensure that tests clearly specify test instructions and acceptance criteria sufficiently to verify operability of components and systems.

12. Verify that an improvement process exists which allows feedback and corrective/improvement actions for incorporating recommendations from vendors, regulators, operating experience, operating history, lessons learned, and self-assessment audits. 
13. Review maintenance program doçumentation and applicable procedures in maintenance and engineering to ensure that maintenance history is adequately maintained. Interview planners and cognizant engineers to assess the use of maintenance history for improving maintenance planning and evaluating the effectiveness of predictive and preventive maintenance tasks.

14. Review how Maintenance uses performance indicators, trending, trend analysis, lessons learned and root cause analysis to monitor maintenance rework and identify the cause of rework. Review the actions taken to reduce the amount of rework.

15. Review calibration records to ensure calibration, reference standards, and non-conformance requirements are controtled.

16. Review preventative maintenance and recalibration schedules and procedures to assure they are inciuded appropriately for safe operation of the facility.

17. Review instrument test program/procedures in order to verify the instrument "set-points" are documented, controlled and maintained as necessary to support safe operation. Verify procedures require recording "as found" and "as left" conditions. Verify these procedures are subject to periodic scheduled reviews to establish they are still valid for plant conditions/configuration.

18. Determine if predictive maintenance is being considered to support mission objectives and thruput requirements and whether criteria are adequately specified for taking corrective actions.

19. Review Preventative Maintenance schedules to verify that the systems technical basis was utilized and facility safety and process thruput commitments were a7so included. Review performed PMs. Place special emphasis on reasons for any missed PMs, how the status of operable equipment is affected, how return to service is accomplished, and how procedures are changed to prevent problem recurrence.

20. Interview the maintenance manager to determine that an interface exists with appropriate communications methods from $Q A$, engineering, operations, safety, and health physics. Assure communications inciude coordination between these technical support/functional groups and maintenance for integration of the quality assurance, configuration management, ALARA, and safety programs on site.

21. Walkdown maintenance areas and assess for adequacy (e.g., location, storage, material segregation, etc.)

Basis:

An effective program of preventive and corrective maintenance enhances availability and operability of equipment and provides data which can be used for continued improvements. An effective maintenance organization is necessary to retain the physical condition of Phase $V$ Storage in a manner that supports safe operation. Maintenance equipment must be maintained and calibrated to ensure that maintenance activities are safe, effective, and 
maintain configuration management controls. Specific controls are unique to maintenance activities which significantly impact safety and equipment reliability. Management's general approach to maintenance sets the organization's cultural bias toward safety and equipment availability. Prior to commencing operation of Phase $V$ Storage, CWC must have their work control, procurement and material control systems operating effectively to ensure adequate work progress, continued operations, and facility safety.

\section{References:}

1. WHC-IP-1120, Rev 4, Standards/Requirements Identification Document (SRIDS)

3. WHC-CM-5-36, Solid Waste Disposal Internal Requirements Section 1-5, Standard Operating Practices

Section 2-1, Procurement Manual

Section 2-3, Property Management

Section 4-2, Quality Assurance

Section 6-1, Standard Engineering Practices

Section 8-7, Operations Support Services

4. WHC-CM-5-34, Solid Waste Disposal Operations Administration

Section 1.9, Quality Assurance Program

Section 1.31, Scheduling

Section 2.1, Configuration Change Control

Section 2.4, Configuration Management

Section 2.11 Job Control System

Section 3.1, Materiai Control 


\section{6}

There is an adequate quality assurance organization and program.

\section{Criteria:}

1. The quality assurance program is clearly defined and documented, has well defined interfaces and responsibilities, and includes a well defined system for audits, surveillances, document review, corrective action, and follow up. There are procedures for systematic reviews and audits, including self-assessments.

2. Quality assurance reports are distributed to the appropriate level of management. The reports reflect adequate and timely QA reviews.

3. Administrative controls are implemented by management to maintain control of the quality assurance program elements.

4. Acceptance/operational tests and inspections are verified to be accurate and complete for systems important to safe operations.

5. Calibration of measurement, test, and monitoring systems are ensured and verified.

6. The Quality Assurance program is effectively implemented through $Q A$ review and approval of procedures and work activities on safety class equipment and personnel safety items.

7. QA personnel have the necessary knowledge, skills and abilities to actively participate in the QA program. (Assessed under Core Requirements 2 and 3, provided here for information and completeness).

8. Software is adequately controlled.

\section{Approach:}

1. Identify and evaluate Quality Assurance Program documentation for adequacy and assess the facility for compliance to WHC-CM-5-34.

2. Review work packages to verify QA personnel approval when required.

3. Verify proper $Q A$ approval of procedures and oversight on specific work items.

4. Use WHC-CM-5-36, Chapter 4-2 and QR 19.0 to determine that the software is properly controlled and maintained.

\section{Basis:}

Experience in the DOE and commercial nuclear industry has shown quality assurance requirements are sometimes not fully implemented into effective QA Programs. 
References:

1. WHC-IP-1120, Rev 4, Standards/Requirements Identification Document (SRIDS)

2. WHC-CM-5-36, Solid Waste Disposal Internal Requirements

Section 3-5, Document Control and Records. Management

Section 4-2, Quality Assurance

3. WHC-CM-5-34, Solid Waste Disposal Operations Administration

Section 1.9, Quality Assurance Program Plan 


\section{7}

Health physics (HP) programs and procedures provide appropriate direction, effectively support safe operation of the facility, and ensure adequate protection of workers, the pubtic, and the environment.

\section{Criteria:}

1. Organization and administration of the HP program ensures effective implementation and control of HP activities.

2. Personnel performing health physics duties have successfully completed HSRCM training and qualification program. (Assessed under Core Requirements 2 and 3, provided here for information and completeness)

3. Programs to evaluate, monitor, and control internal and external radiation exposure, (e.g., dosimetry, exposure records, trend analysis, bioassay program, work area radiation records, procedures, etc.).

4. Programs to control radioactive material are effective in: 1) providing adequate packaging, labeling, accountability, and safe transportation of such material; and 2) minimizing the contamination of areas, equipment, and personnel.

5. Facility Radiological Work Permits (RWPs) are adequate to protect the worker, public, and environment. RWPs contain adequate provisions for protective equipment, work limitations, job descriptions, and special instructions. RWPs are posted at entrances to work areas. Out-of-date RWPs are removed in a timely manner.

6. Facility status boards adequately represent radiological conditions of the facility and provide enough information to personnel to allow safe operations and minimize exposure.

7. Facility posting is adequate to provide personnel with enough information to allow safe operations and minimize exposure. Posting is in accordance with all requirements.

8. An ALARA program has been established and successfulty implemented. ALARA program has taken into account all facets of exposure reduction (e.g., posting hot spots, shielding, special tools, monitoring, traffic routing, location of office areas and work stations, protection from transient radiation, adequate communications).

9. Source material is adequately controlled, labeled, handled, shipped, received, and surveyed.

10. Fail safe interlocks are used, tested, and documented on radiation generating devices, and barriers are adequateiy used to ensure the safety of operators and other personnel.

11. Set points to activate interlocks or other safety systems associated with radiation generating devices are defined. 
12. The radiation field around radiation-generating devices and radioactive material has been well characterized (type, energy, and dose range).

13. Warning signs are posted at radiation-generating devices.

14. Area radiation monitoring equipment are used for radiation generating devices.

15. Radiological protection/measurement instruments (fixed and portable)

16. Instruments have current caijbration stickers and are in a recall system.

17. Instrumentation is adequate to meet facilities needs (range, type, location, number, air flow rate, etc.).

18. A documented, acceptable air monitoring program is in place, and is supported by sufficient studies (e.g., air flow patterns, particle size, etc.).

19. Contamination controls are adequate to protect the worker (e.g., PPE removal procedures are posted, contaminated and non contaminated areas are routinely surveyed, Taundry procedures minimize contamination spread, airborne generating devices, such as fans and vacuum cleaners, are adequately controlled, personnel monitoring is adequate, decontamination facilities are available, proper engineered barriers, etc.).

\section{Approach:}

1. Review the organizational structure of the health physics group and its relationship to the line management structure. Determine if the organizational structure is clearly defined.

2. Interview the Health Physics Manager and staff members to determine if adequate resources are provided by consistent with the radiological risk of the facility as defined in the ISB and CSER.

3. Review operating procedures and health physics procedures to determine their adequacy in supporting normal, process upset, and documented emergencies. Assure they were prepared in accordance with the approved Writers Guide.

4. Determine if performance indicators will be used to assess the facility radiological control performance and how corrective actions will be identified and tracked.

5. Verify exposure records are maintained for appropriate personnel.

6. Review radiological survey procedures and techniques for the release of materials.

7. Review facility programs and procedures intended to reduce the volume of radioactive material generated from the facility. 
8. Determine if personnel are aware of waste reduction policies. and if waste collection containers are provided for clean waste and radioactive waste to minimize radwaste generated.

9. All areas are controlled to prevent the spread of contamination.

10. Tour facility and ensure all required posting, boundaries, radiation monitoring equipment are in place.

11. Review selected RWPs used in critical process areas for applicability, correct controls, accuracy, and completeness.

12. Tour facility and ensure all required status boards are in place to properly define facility conditions.

13. Observe a demonstration of the facilities ability to assess radiological hazards to personnel, the public, and environment, based on quantities released, materials, and meteorology using analys is results in the ISB and CSER.

14. Verify an ALARA program has been established and is being utilized.

15. Review documentation and tour the facility to ensure sources of radiation are properly controlled.

16. Ensure contamination control procedures are understood by interviewing field personnel, performing a facility tour and reviewing documentation.

Basis:

This review is based on functional requirements contained in State and Federal requirements.

\section{References:}

1. WHC-IP-1120, Rev 4, Standards/Requirements Identification Document (SRIDS)

2. WHC-CM-5-36, Solid Waste Disposal Internal Requirements Section 4-27, Radiological Control Practices and Procedures

3. WHC-CM-5-34, Solid Waste Disposal Operations Administration Section 1.14, ALARA Program

Section 1.30, Conducting Self Survey at Solid Waste Disposal

\section{8}

Industrial hygiene and safety programs, policies, and procedures have been developed which are consistent with the hazards present or anticipated in the working environment as well as with DOE Orders and OSHA standards. The overall program is effectively managed to promptiy address and remedy hazards, and systems are in place to communicate information to workers in order to prevent occupational injuries and illnesses.

\section{Criteria:}

1. A formal safety and health program has been developed which includes procedures and policies consistent with DOE Orders and OSHA. 
2. Sufficient resources are available and dedicated to occupational safety and health to operate an effective program. Personnel, equipment, and reference materials are available to administer the program.

3. Appropriate record keeping procedures have been established to document injuries, illnesses, and accident occurrences and to permit the ready analysis of such records.

4. Training effectively performs required Industrial Hygiene and Safety training. The content of training programs adequately addresses all requirements and hazards at the facility, is effectively communicated, and records are maintained. (assessed under Core Requirements 2 and 3, provided here for information and completeness).

5. Sufficient work place surveillance exists to seek and track safety and health hazards. Regular and periodic audits are conducted to assess work place conditions.

6. Noncompliant conditions are documented, corrective action dates established, and tracking programs implemented to assure prompt abatement of observed hazards. Where engineering or administrative controls are not readily implemented, personal protective equipment is available and used to provide employee protection.

7. A system exists and is utilized whereby employees may identify safety and health hazards to their manager for corrective action without fear of reprisal. Employees are aware of their access rights to information including medical and monitoring records and Material Safety Data Sheets.

8. As a minimum Industrial Safety, Industrial Hygiene, and Nuclear Safety should have assessed the following respectively:

A - 1. Work area is safe, free of tripping hazards, clean, appropriate signs posted, barricaded as appropriate, floors dry and loading capacities posted; 2. Electrical equipment is properly grounded, Ground Fault Interrupters (GFI) provided where required, power control panels and breakers labeled, and electrical devices properly covered/protected; 3 . Heat generating appliances/equipment are a safe distance from combustible material; 4. Machine guards in place, caution/warning signs posted, physical safety systems operational/functional and can not be inadvertently bypassed and safety devices (i.e. relief valves) provided; 5. Equipment/machines adequate/safe for job, special hand tools/handling devices for material handling provided; 6 . Personal protective equipment/clothing provided; 7. A job hazard analysis (JHA) has been performed; 8. A Lock and Tag system is in place.

B - 1. Lavatories functional, potable water lines disinfected and tested, black flow prevention devices functional, and water pressure adequate; 2 . Inside/outside facility lighting adequate; 3 . HVAC adequate, humidity controls if needed functional; 4 . Site enclosed, as appropriate, to prevent entrance/harborage of rodents/insects, special/unique facility cleaning requirements provided for, and proper waste containers provided; 5. Noise controlled; 6 . Personnel exposure to chemical hazards controlled. 
C - 1. USQ process; 2. Implementation of ISB requirements; 3 . Implementation of Criticality Safety Requirements.

9. A system is in place and implemented to estimate quantities and assess the integrated impact of hazardous material releases on personnel and the public.

10. Ladders, guard rails, and fall protection equipment are well maintained and meet applicable standards.

Approach:

1. A review of all relevant aspects of the formal safety and health program will be undertaken to evaluate the content for accuracy, adequacy, and consistency with DOE Orders and OSHA.

2. Safety and health resources, such as staffing, equipment, and the availability of reference resources will be evaluated to determine whether knowiedge and tools exist to operate and manage an effective program.

3. Review the frequency of scheduled safety inspections to assure it meets the needs of the facility's mission objective.

4. Review records to determine if they are properly maintained. This review will include injury and $i 17$ ness records and inspection records.

5. A physical walk through of selected areas of the facility will be performed to observe actual work site conditions and practices to assess compliance with existing requirements, and the effectiveness of internal audits. As a minimum the following will be assessed: 1) Work area is safe, free of tripping hazards, clean, appropriate signs posted, barricaded as appropriate, floors dry and loading capacities posted, 2) Electrical equipment is properly grounded, Ground Fault Interrupters (GFI) provided where required, power control panels and breakers labeled, and electrical devices properly covered/protected, 3) Heat generating appliances/equipment are a safe distance from combustible material, 4) Machine guards in place, caution/warning signs posted, physical safety systems operational/functional and can not be inadvertently by passed and safety devices (i.e. relief valves) provided, 5) Equipment/machines adequate/safe for job, special hand tools/handling devices for material handling provided, 6) Personal protective equipment/clothing provided, 7) A job hazard analysis (JHA) has been performed, 8) A Lock and Tag system is in place, 9) Lavatories functionaT, potable water lines disinfected and tested, black flow prevention devices functional, and water pressure adequate, 10) Inside/outside facility lighting adequate, 11) HVAC adequate, humidity controls if needed functional, 12) Site enclosed, as appropriate, to prevent entrance/harborage of rodents/insects, special/unique facility cleaning requirements provided for, and proper waste containers provided, 13) Noise controlled, 14) personnel exposure to chemicals, and, 15) Nuclear Safety issues (USQ procesS, ISB requirements, criticality issues).

6. Employee interviews will be conducted to determine the extent of their knowledge regarding worker rights, such as Employee Concern program and access to information. 
7. Review procedures and observe equipment for sampling, monitoring, and analyzing hazardous substances to ensure that provisions are in place to collect data for notification and reporting as directed by Federal and state requirements.

Basis:

OSHA, and DOE Orders require that occupational safety and heal th programs ensure that employees are informed of potential hazards that may be encountered in the work $\mathrm{place}$ and that the associated controls are in $\mathrm{place}$ to maintain risks at an acceptable level. Effective procedures must be established and enforced to protect the employees' safety and health.

\section{References:}

1. WHC-IP-1120, Rev 4, Standards/Requirements Identification Document (SRIDS)

2. WHC-CM-5-36, Solid Waste Disposal Internal Requirements Section 1-10, Safety Manual

Section 1-11, Industrial Hygiene (NEW)

Section 4-29, Nuclear Criticality Safety

Section 4-40, Industrial Hygiene (OLD)

3. WHC-CM-5-34, Sol id Waste Disposal Operations Administration Section 1.15, Safety Analys is

Section 2.17, Criticality Safety 


\section{9}

There is a security organization and program that adequately supports the requirements of operations.

\section{Criteria:}

1. The organizational structure is clearly defined and staffing and resources are sufficient to accomplish tasks assigned to the organizational elements. Responsibilities, authority, and interfaces for each organizational position are clearly defined and understood. Interfaces with other CWC organization is well defined and understood. (Assessed under Core Requirements 11 and 13, provided here for information and completeness)

2. Procedures and controls that assure safe and reliable operations are employed in the conduct of security activities.

\section{Approach:}

1. Review procedures which control the security program for adequacy and implementation.

\section{Basis:}

CWC has an important DOE mission as we11 as valuable physical and personnel resources. It is therefore important that these resources be protected by a competent and dedicated security organization. The ORR review is to establish that the general scope, personnel qualifications, and demonstrated competence of the Security organization is adequate to support operations.

\section{References:}

1. WHC-IP-1120, Rev 4, Standards/Requirements Identification Document (SRIDS)

2. WHC-CM-5-36, Solid Waste Disposal Internal Requirements

Section 2-3, Property Management

Section 4-7, Unclassified Computer Security

Section 4-33, Security Manual

3. WHC-CM-5-34, Solid Waste Disposal Operations Administration Section 3.7, Shift Routines 


\subsection{0}

There exists an adequate configuration management program to assure necessary change and drawing control of plant structures, systems, and components and to assure changes are reflected in training, procedure development, maintenance instructions, and technical base 7 ine.

\section{Criteria:}

1. Configuration Management procedures/policy exists and are clearly communicated and understood by all levels of the organization. Appropriate graded approach is utilized consistent with the safety class of process and utility equipment/systems.

2. Responsibilities and interfaces for configuration management are clearly defined. (Assessed under Core Requirement 11, provided here for information and completeness)

3. Documents, drawings, and other references which define the facility configuration are readily available, authorized, properly controiled and are used in designing plant changes, preparing facility procedures, troubleshooting, etc.

4. Management ensure that changes to the facility are warranted and properly controlled.

5. An administrative program is in place to ensure that modifications are analyzed, documented, approved by appropriate personnel and organizations, and reflected in design drawings, revised operations; training, and maintenance procedures.

6. The configuration of systems as contained on as-built drawings have been physicalty verified.

7. Procedures and management policies for changes to the facility are properly executed.

8. The design control program was properly implemented in the design of the facility.

9. Programs are defined, and procedures are in place to specify methods for identifying, addressing, and reconciling questions concerning alterations to the design, function, or method of performing the function of a structure, system, or component as described in the authorization basis.

10. Temporary modification are controlled to ensure facility configuration is maintained.

\section{Approach:}

1. Review the configuration management program to determine the adequacy of facility interfaces required to maintain configuration management, proposed change review and approval, configuration control drawings, vendor manuat control. 
2. Interview the responsible manager for configuration management to assess the backlog of design changes, backlog of drawing changes, backlog of facility modifications, prioritization scheme for facility changes, and the interface with maintenance, training, and operations personnel concerning impacts of new and revised design requirements.

3. Verify that Certified Vendor Information files are in place and are correctly referenced with the $\mathrm{H}-2$ drawings.

4. Confirm a program is in place and has been implemented requiring the physical walk down of systems to verify the accuracy of applicable design drawings/documentation. Confirm the validation/verification process by performing a waik down to ensure systems are documented as built.

5. Verify that the change control process has been adequately implemented and that temporary and permanent changes are adequately controlled.

6. Review a major change to the facility/systems to estabijsh that the change was properly analyzed (for functionality, safety, authorization basis, and possible interactions with other systems), documented, and reviewed, including, where necessary, reviews by independent organizations.

\section{Basis:}

These criteria ensure activities associated with plant configuration are appropriately controlled to maintain the facility configuration in conformance with design requirements. Conduct of operations require that drawings relied upon by operators and maintenance personnel must accurately reflect the plant configuration, and that the function, design basis, and current status of equipment and systems, required for safe operation, are known and documented, with up-to-date accurate records. These drawings must be prepared, approved, controlled, and used to ensure that the plant is operated safely and within all safety related limits.

\section{References:}

1. WHC-IP-1120, Rev 4, Standards/Requirements Identification Document (SRIDS)

2. WHC-CM-5-36, Solid Waste Disposal Internal Requirements

Section 3-5, Documentation Control and Records Management

Section 6-1, Standard Engineering Practices

Section 6-2, Project Management

3. WHC-CM-5-34, Solid Waste Disposal 0perations Administration

Section 1.8, Training Administration

Section 1.24, Unreviewed Safety Questions

Section 2.1, Configuration Change Control

Section 2.2, Solid Waste and T Plant As-Built Drawing Control

Section 2.4, Configuration Management Section. 2.11, Job Control System

Section 3.13 , Control of Equipment and System Status

Section 3.22, Operating Procedures 


\subsection{1}

An adequate records management/document control program exists to assure that all important documents, records, and related information are maintained current and readily retrievable.

\section{Criteria:}

1. The records management program defines responsibilities for determining what documents will be controlled in a system; methods used for acquisition, identification, storage, retention, and retrieval of documents; and controls to be exercised for changes, distribution, and removal.

2. The records management program scope includes receipt or preparation, review and approval, and distribution of documents generated externally and internally in a timely manner.

3. The records management program inciudes processes, interfaces and responsibilities for controlling design bases and technical documents, such as calculations, specifications, drawings, vendor manuals, records of maintenance, test results, etc.

4. Necessary documents are kept current and legible and are either available at appropriate plant locations or can be provided in a timely manner.

5. The document control program assures that uncontrolled drawings, manuals, and procedures are not used at the work location.

6. Documentation is stored correctly (e.g., fire proof cabinets for QA records).

\section{Approach:}

1. Review the program and procedures which define the records management system.

2. Review records management program and implementing procedures in engineering, maintenance, operations, and materials management to ensure responsibilities and processes are documented for controlling technical documentation. Sample the efficiency of the system by selecting one system important to safe operations and requesting documents associated with design, procurement, construction, maintenance, and operability of one or two significant pieces of equipment in that system. Interview selected facility management to assure they are knowledgeable of records management and retention polices and procedures.

3. Observe work in process involving structures, systems, and/or components, note any use of uncontrolled drawings, procedures, or manuals.

\section{Basis:}

An effective records management program is necessary to ensure that proper information is available for planning, decision-making, and performance 
audits. Timeliness and availability of records, especially technical documentation, is important for ensuring the safety and health of workers and protection of the environment.

References:

1. WHC-IP-1120, Rev 4, Standards / Requirements Identification Document (SRIDS)

2. WHC-CM-5-36, Solid Waste Disposal Internal Requirements

Section 3-4, Information Release Administration

Section 3-5, Document Control and Records Management

Section 3-6, Uniform Pub7ication System

4. WHC-CM-5-34, Sol id Waste Disposal Operations Administration

Section 1.1, External Correspondence and Technical Work Document

Approvals

Section 1.13, Processing and Transferring Records

Section 2.1, Configuration Change Control

Section 2.2, Solid Waste and T Plant As-Built Drawing Control

Section 2.4, Configuration Management

Section 2.11, Job Control System

Section 3.17 , Logkeeping 


\subsection{2}

There exists an occurrence reporting/root cause program.

\section{Criteria:}

1. An occurrence reporting program is established which ensures that sufficient personnel are trained in root cause analysis techniques and are available.

2. The program shall ensure that those conducting investigations are independent of the cause of the unusual event.

3. The "lessons learned" which are developed as a result of the program implementation and root cause analys is shall be incorporated into the corrective action system to prevent recurrence.

4. The program should contain provisions to call in personnel with special expertise to assist in the occurrence investigation.

\section{Apprọach:}

1. The program will be reviewed in order to determine if the programmatic aspects ensure that knowledgeable and independent (if applicable) personnel conduct investigations.

2. Review completed assessments (if available) and verify that personnel performing the assessments were independent of the area assessed.

4. Review completed assessments (if available) to determine the specific findings and/or recommendations generated as a result of the assessment. Verify the incident and lessons learned have been incorporated into the training and re-training programs. Verify that the root causes have been determined, and corrective actions have been discussed with the appropriate plant staff.

5. Ensure assessment teams be supplemented with special expertise (if required) to assist in the occurrence investigation. Through discussion with cognizant personnel, identify and review an assessment (if available) where outside special expertise was required.

\section{Basis:}

An assessment program which specifies the skills, knowledge, and abilities required to perform occurrence investigations and ensures that corrective actions are implemented to prevent recurrence is essential to verifying the adequacy of activities.

\section{References:}

1. WHC-IP-1120, Rev 4, Standards/Requirements Identification Document

2. WHC-CM-5-36, Solid Waste Disposal Internal Requirements

3. WHC-CM-5-34, Solid Waste Disposal Operations Administration 
Core Requirement 9

A routine and emergency operations drill program, including program records, has been established and implemented.

\section{Interpretation:}

The adequacy of the Emergency PIan and Emergency Preparedness Organization is to be assessed under Core Requirement 8 . This Core Requirement does not require a review of the Emergency Plan except to ensure that an adequate cross section of emergency situations are addressed by the drill program.

\section{Criteria:}

1. The drill program adequately plans, schedules, prepares, conducts, critiques, and documents drills.

Approach:

1. Compare the Emergency Plan to the drill program to assess the adequacy and applicability of drills to the facility.

2. Observe and assess a dril1.

3. Review and assess the results of the dri11(s) and assess the resolution of deficiencies.

4. Review records of routine and emergency drills for adequacy and completeness.

5. Personnel are apprised of the results of the drill critiques and are included in the lessons learned program.

Basis:

An effective emergency preparedness, and response program is necessary to help ensure the safety and health of workers, the public, property and environment in the event of an emergency. Emergency management programs should be in place to enable organizations to respond to an emergency in a timely; efficient, and effective manner, resulting in mitigation of consequences and recovery. A drill program is required to periodically test the program to ensure proper functionality.

\section{References:}

1. WHC-IP-1120, Rev 4, Standards/Requirements Identification Document (SRIDS)

2. WHC-CM-5-36, Sol id Waste Disposal Internal Requirements

3. WHC-CM-5-34, Solid Waste Disposal Operations Administration

4. DOE - 0223, Emergency Plan Implementing Procedure

5. HNF-PR-000424, Maintaining Facility Emergency Preparedness 
Core Requirement 11

Functions, assignments, responsibilities, and reporting relationships are clearly defined, understood, and effectively implemented with 1 ine management responsible for control of safety.

\section{Interpretation:}

This applies to all facjlity and direct support personnel/groups

(Environmental Compliance, Fire Protection, Maintenance, QA, Health Physics, Training, Industrial Hygienist, Industrial Safety, Nuclear Safety, Laboratories, Security, Records Management, and Occurrence Reporting, Emergency Preparedness, etc). The review is to ensure that management has developed adequate position descriptions, job definitions, and reporting relationships and has adequately informed and trained all facility personnel on them.

\section{Criteria:}

1. Policies/procedures exist defining the responsibility, authority, accountability, and reporting relationships of each management position, exempt position, non-exempt position, bargaining unit, and direct support personnel (e.g., Environmental Compliance, Fire Protection, Engineering, Maintenance, QA; Health Physics, Training, Industrial Hygienist, Industrial Safety, Nuclear Safety, Laboratories, Security, Records Management, Projects, Occurrence Reporting, Emergency Preparedness, etc.).

2. All personnel associated with the facility understand and impiement their responsibilities, authority, accountability and reporting relationships.

3. Department interface and bounds are clearly defined and understood.

4. Support group interface and bounds are clearly defined and understood.

5. Oversight interface and bounds are clearly defined and understood.

6. Managers have appropriate access to DOE, regulators, and emergency organizations on matters of safety and environmental protection.

7. Line organizations are unencumbered by excessive duties or significant duties unrelated to the day-to-day operation.

8. Managers encourage and effectively foster teamwork and cooperation among interfacing organizations.

9. Directives and other management information flow quickly and accurately through the management chain and other formal channels of communication.

10. An adequate program exists for dissemination of general information to employees regarding the facility.

11. Position descriptions are available. 
12. Subcontractors understand their reporting relationships and responsibilities. Subcontractor interface and bounds are defined and understood.

\section{Approach:}

1. Obtain organization charts, position descriptions, and procedures to establish that there exists, for individuals and departments, clear definitions and bounds of authority, accountability, responsibilities, and reporting relationships.

2. Interview facility personnel to determine the adequacy of collateral duties, contractor/subcontractor interfaces and accountability, delegation practices, management attitude and practices which foster or hinder cooperation and teamwork, effectiveness of information flow (timeliness, adequacy, emphasis on safety and environmental protection).

3. Interview managers to ensure there exists adequate access to DOE, regulators, and emergency organizations on matters of safety and environmental protection.

\section{Basis:}

Management is responsible for the organization and coordination of work in order that responsibilities, authorities, and accountability are clearly understood and that responsibility for safety is prevaient throughout the organization. Documentation of the organization and coordination of the work combined with implementation of the documented policies and procedures are equaliy important. A basic responsibility of management is to ensure that effective coordination and communication exists between and within various levels of the organization.

\section{References:}

1. WHC-IP-1120, Rev 4, Standards/Requirements Identification Document (SRIDS)

2. $\mathrm{HHC}-\mathrm{CM}-5-36$, Sol id Waste Disposal Internal Requirements Section CM-1, Policies and Charters 
Core Requirement 12

The implementation status for DOE Order 5480.19, Conduct of Operations requirements for DOE facilities, is adequate for operations.

\section{Interpretation:}

This Core Requirement is to ensure the facility is complying with all Conduct of Operations requirements as writien in WHC-CM-5-34.

\section{Criteria:}

1. The facility has implemented the WHC-CM-5-34 Conduct of Operations chapters specifically the following:

- 3.6, Operations Maintenance (assessed under Core Requirement 8)

- 3.7, Shift Routine and 0perating Practices

- 3.9, Communication,

- 3.10, On The Job Training (assessed under Core Requirement 2 and 3)

- 3.13, Control of Equipment and System Status

- 3.14, Lockout and Tagout

- 3.15, Independent Verification

- 3.16, Alarm Management

- 3.17, Logkeeping

- 3.18, Operations Turnover

- 3.19, Chemistry and Unique Processes

- 3.20, Required Reading

- 3.31, Timely Orders to Operators

- 3.22, Operation Procedures

- 3.23, Operator Aid Posting

- 3.24, Equipment and Piping Labeling

\section{Approach:}

1. Review and assess the facility's implementation of each applicable chapter in WHC-CM-5-34, Section 3.0, Operations.

\section{Basis:}

The organization and administration of facility Operations should ensure a high level of performance in Operations is achieved through effective implementation and control of Operations activities. Clear lines of responsibility for normal, alarm, and emergency conditions should be established. Effective implementation and control of operating activities may be achieved by establishing written standards for Operations, periodically monitoring and assessing performance, and holding personnel accountable for their performance. Good operating discipline ensures facility and process configuration is maintained in accordance with design requirements, and that the operating staff knows the status of facility and process equipment and systems at a11 times.

\section{References:}

1. WHC-CM-5-34, Solid Waste Disposal Operations Administration 


\section{Core Requirement 13}

There are sufficient numbers of qualified personnel to support safe operations.

\section{Interpretation:}

This Core Requirement is only to ensure adequate numbers of qualified personnel. Assessment of qualification is addressed under Core Requirements 2 and 3 .

\section{Criteria:}

1. There is an adequate number of qualified personnel for the mission of the facility.

2. The staffing requirements are adequate to ensure safe operations.

\section{Approach:}

1. Using qualification records and job assignment records, compare the numbers of qualified personnel to the staffing levels identified by facility management to ensure Criterion 13.1 is met.

2. Verify the staffing levels are greater than or equal to any minimum staffing requirements identified in the authorization basis.

3. Review and assess staffing requirements identified by the authorization basis and line management by witnessing the performance or walking down plant operating procedure and work plans to verify that adequate numbers of personnel are available to operate the systems.

\section{Basis:}

Adequate numbers of qualified personnel are required to ensure the facility can be operated safely, efficiently, and compliantly. Inadequate staffing puts undue stress on plant personnel, creates unsafe work practices, corner cutting, inattention to detail, poor work atmosphere, excessive backlog, and endangers the environment.

\section{References:}

1. WHC-IP-1120, Rev 4, Standards/Requirements Identification Document (SRIDS)

2. WHC-CM-5-36, Solid Waste Disposal Internal Requirements Section 1-3, Management Requirements and Procedures

4. WHC-CM-5-34, Solid Waste Disposal Operations Administration Section 1.8, Training Administration 


\section{Core Requirement 15}

The facility systems and procedures as affected by facility modifications, are consistent with the description of the facility, procedures, and accident analysis included in the safety basis.

\section{Interpretation:}

This core requirement applies to having programs and/or processes in place to assure equipment, systems, facilities, and organizations are prepared for processing following major modifications. It includes all aspects required for the successful restart/start of operations and assure that the approved safety basis performance requirements are satisfied and institutionalized appropriately for a category 2 facility.

\section{Criteria:}

1. Operations, maintenance, surveillance, and administrative procedures have been adequately updated to reflect the facility modifications and meet or exceed the operational performance guidance provided in DOE order 5480.19.

2. Operations, maintenance, surveillance, and administrative procedures implement the changes made in the approved safety basis resulting from the facility modifications.

3. An adequate process has been implemented to ensure that documentation for systems critical to and support the safety of the facility exist, reflect the current facility modifications, and are kept current.

4. Drawings and other documentation relied upon for operations and maintenance activities are consistent with the new existing plant configuration.

5. An equipment/system startup program is in place and adequately addresses operations testing to confirm operability of equipment, the viability of procedures, and the training of operators.

6. Construction vendors have completed all work and appropriate turnover documentation has been supplied to the operating organization. These need to include the construction checklist and open items punchlists.

7. Utility and support systems are operable, fully functional, and meet the performance requirements of the approved safety basis.

8. A USQ screening relative to the planned modification was completed prior to initiation of design and was appropriately dispositioned.

9. The Functional design criteria for modifications was utilized by the construction vendors for design, fabrication, and installation.

\section{Approach:}

1. Review validation, walkdown, and review comments for recent procedure changes that incorporate the needs of operating and managing the CWC 2404 
phase $V$ facility and have correctly included the requirements of the safety basis.

2. Interview operations staff to assess their understanding of the operational requirements for the 2404 facility and how the Administrative Operational Safety Requirements are met.

3. Interview technical support staff to assess their knowledge of both the operational and administrative procedure change process that implemented the additional requirements of the 2404 facility.

4. Review with technical support personnel that vendor drawings, specifications, and operational characteristic data have been properly incorporated and user staff notified.

5. Review with technical support personnel responsible for modifications that vendor turnover open items have been properly dispositioned and a formal process to verify construction activities met functional design criteria was utilized.

6. Review the listing of safety support systems to ensure consistency with the safety basis. This includes defined organizational roles, responsibilities, and interfaces required to meet the AOSRs.

7. Interview personnel associated with configuration management and record storage to assess their understanding of program requirements and responsibilities.

Basis:

To determine if procedures, systems, equipment, and personnel have been integrated to allow safe, efficient, and compliant operation after the facility modification.

\section{Requirements}

1. WHC-IP-1120, Rev 4, Standards/Requirements Identification Document

2. WHC-CM-5-36, Sol id Waste Disposal Internal Requirements

3. WHC-CM-5-34, Sol id Waste Disposal Operations Administration 


\section{Core Requirement 19}

The technical and management qualifications of contractor personnel, responsible for facility operations, are adequate.

\section{Interpretation:}

This Core Requirement applies to all management associated with the facility. Al1 other personnel are assessed under Core Requirements 2 and 3.

\section{Criteria:}

1. Management has adequate on-the-job experience and/or training/education that qualifies them for their positions.

2. Adequate documentation of management qualifications is available.

3. Examinations, given to management personne?, are adequate in their depth and breadth of subject matter as it pertains to facility operations.

\section{Approach:}

1. Review test material to verify that they adequately reflect training content and test for an understanding of technical fundamentals, procedures, ACs, TSRs, $\mathrm{plant}$ activities, and responsibilities associated with emergency response.

2. Review and assess management qualification requirements for adequacy.

3. Review and assess completion of qualifications and test results for management personnel.

4. Conduct interviews to determine the extent of knowledge of technical fundamentals, procedures, ACs, plant activities, and responsibilities associated with emergency response.

Basis:

The DNFSB Recommendation 92-6 delineated some of the important facets of a readiness review. These included assessment of the technical and managerial qual ifications of contractor personnel responsible for direction, guidance, and operation of the facility.

\section{References:}

1. WHC-IP-1120, Rev 4, Standards/Requirements Identification Document (SRIDS)

2. WHC-CM-5-34, Solid Waste Disposal Operations Administration Section 1.8, Training Administration Section 3.10, On-the-Job Training 


\section{APPENDIX C: ORR FORMS}


Appendix C: ORR Forms

PHASE V STORAGE ORR APPRAISAL FORM

CORE REQUIREMENT:

APPROACH:

CRITERIA:

\begin{tabular}{|l|l|l|l|l||}
\hline \multicolumn{1}{|c|}{$\begin{array}{c}\text { SUBJECT/ACTIVITY } \\
\text { REQUIREMENT REFERENCE }\end{array}$} & $\begin{array}{c}\text { EVIDENCE EXAMINED/ } \\
\text { PERSONMEL CONTACTED }\end{array}$ & OBSERVATIONS/COMMENTS & \multicolumn{2}{|c|}{ COMPLY } \\
\hline 1) & & & YES & No \\
\hline 2$)$ & & & & \\
\hline 3$)$ & & & & \\
\hline 4$)$ & & & & \\
\hline 5$)$ & & & & \\
\hline
\end{tabular}




\section{ORR FINDING FORM}

FINDING NUMBER: F. (example F.1.1.1, refers to Core Requirement 1, Criteria 1, Finding 1, F.1.1.2 would refer to Core Requirement 1, Criteria 1, Finding 2, etc.)

CORE REQUIREMENT NUMBER: CORE REQUIREMENT STATEMENT:

CRITERIA NUMBER:

CRITERIA STATEMENT:

DATE:

FINDING STATEMENT:

WRITING INSTRUCTIONS

Provide a concise statements of the finding. It is not to list actions

that must be done to correct findings. It is not to be a general statement of whether or not readiness has been achieved (this will be a general board

statement in the report). Hard and electronic copies of forms will be

provided to RT members. Format provided here for information.

DISCUSSION/CONCLUSION:

RECOMMENDATION:

RESOLUTION:

SIGNATURES:

TEAM MEMBER:

TEAM LEADER: 
Appendix C: ORR Forms

\section{ORR OBSERVATION FORM}

OBSERVATION NUMBER: 0 . (exampTe 0.1.1.1, refers to Core Requirement 1, Criteria 1, Observation 1, 0.1 .1 .2 , refers to Core Requirement 1, Criteria 1, Observation 2)

CORE REQUIREMENT NUMBER:

CORE REQUIREMENT STATEMENT:

CRITERIA NUMBER:

CRITERIA STATEMENT:

DATE:

OBSERVATION STATEMENT:

WRITING INSTRUCTIONS

Provide a concise statement as to the observation. Since an observation is not a Finding: less time, energy and resources should be spent developing.

Hard and electronic copies of forms will be provided to RT members. Format

provided here for information.

\section{DISCUSSION/CONCLUSION:}

\section{RECOMMENDATION:}

\section{RESOLUTION:}

\section{SIGNATURES:}

TEAM MEMBER:

TEAM LEADER: 


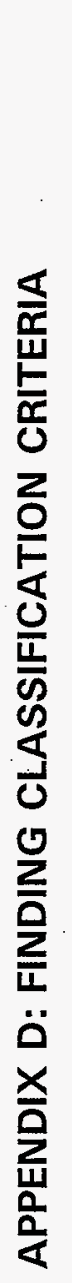

怘
品
吕

음

กั

출

0

离

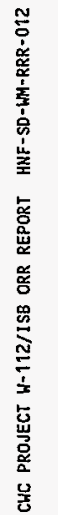




\section{APPENDIX D: FINDING CLASSIFICATION CRITERIA}

These criteria will be used by the team to determine if a finding must be resolved before startup.

\section{A. Initial Screening}

1. Does this finding involve a system that provides personnel safety and/or protects the environment?

2. Does this finding involve processes, functions or components identified in the technical safety requirements/operational safety requirements (TSR/OSR) or nuclear safety control procedures?

3. Does this finding involve potentiai adverse environmental impact exceeding regulatory or site-specific release limits?

4. Does this finding impact non-safety processes, functions or components which could adversely impact safety related processes, functions or components?

5. Is this finding noncompliant with a RFSH or DOE/RL approved requirements document?

6. Does this finding indicate a lack of adequate procedures or administrative systems?

7. Does this finding indicate operational or administrative noncompliance with procedures or policy?

8. Has this finding occurred with a frequency that indicates past corrective actions have been lacking or ineffective?

9. Does this finding require operator training not specified in existing facility training requirements?

10. Does this finding impact worker health and safety?

11. Does this finding impact the performance of the facility mission?

If the response to any of the above is yes, further evaiuation, in accordance with the finding impact criteria is required. If the response to all of the above is no, the finding is considered to be poststart. 


\section{B. Finding Impact Criteria}

1. Does the loss of operability of the item prevent safe shutdown, or cause the loss of essential monitoring?

2. Does the loss of operability of the item require operator action in less than 10 minutes to prevent or mitigate the consequences of events described in the safety anaiysis?

3. Does the loss of operability of the item cause operation outside the TSR/OSRs or safety analysis?

4. Does the loss of operability of the item result in a reduction of the margin of safety?

5. Does the finding indicate a lack of control which can have a near-term impact on the operability or functionality of safety related system?

6. Does the finding result in an unacceptable impact on worker health or safety?

7. Does the finding prevent the facility from performing its mission?

If the response to any of the above questions is yes, the finding is considered to be prestart. . If the response to all of the above questions is no, the finding is considered to be poststart. However, some poststart findings may be changed to prestart by the team leader due to potential health, safety, and/or environmental, significance. 


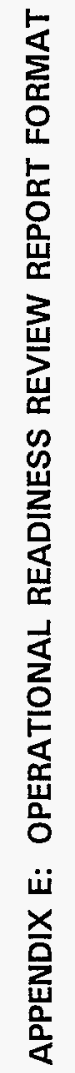


1. TITLE PAGE - The title page is the report cover and will state the subject and dates of the ORR.

2. SIGNATURE PAGE - This page will contain the signatures of the Team Leader and all team members.

3. TABLE OF CONTENTS - The Table of Contents will identify all sections and subsections of the report, and appendices.

4. EXECUTIVE SUMMARY - This is a brief summary of the ORR process, the Findings and the conclusions as to the readiness of the facility to commence operations, with the appropriate recommendation.

5. INTRODUCTION - The introduction will provide information regarding the facility, the purpose of the ORR, and the scope of the ORR. It should also contain a brief discussion of the ORR process and team composition.

6. Team Evaluation - The report will present the review logic of appraising each core requirement and determining the associated prestart and poststart findings. The report will also provide conclusions as to readiness of the facility to commence operations and the recommendation of the team leader. The appraisal forms provided in the appendices will be referenced to provide the review logic for each finding.

7. CONCLUSIONS and CATEGORIZATIONS - The report will provide a summary of findings and observations as they relate to facility operational capabilities, training quality safety, management, compliance, etc.

8. LESSONS LEARNED - Lessons learned that may apply to future ORRs will be provided. Problems as well as successes will be documented. This may be issued at a later date as an addendum to the ORR report.

9. APPENDICES - Appropriate data will be provided as appendices to support the conclusions drawn in the report. These will include:
a) Master finding list
b) ORR finding forms
c) Master observations list
d) ORR observation list
e) ORR appraisal forms
f) ORRIP
g) Completed prerequisite checklist
h) RT member qualifications
i) Dissenting opinions 